PNL-10113

UC-802

\title{
Radiochemical Analyses of Several Spent Fuel Approved Testing Materials
}

\author{
R. J. Guenther \\ D. E. Blahnik \\ N. J. Wildung
}

September 1994

Prepared for

the U.S. Department of Energy

under Contract DE-AC06-76RLO 1830

Pacific Northwest Laboratory

Richland, Washington 99352 



\section{DISCLAIMER}

This report was prepared as an account of work sponsored by an agency of the United States Government. Neither the United States Government nor any agency thereof, nor any of their employees, make any warranty, express or implied, or assumes any legal liability or responsibility for the accuracy, completeness, or usefulness of any information, apparatus, product, or process disciosed, or represents that its use would not infringe privately owned rights. Reference herein to any specific commercial product, process, or service by trade name, trademark, manufacturer, or otherwise does not necessarily corıstitute or imply its endorsement, recommendation, or favoring by the United States Government or any agency thereof. The views and opinions of authors expressed herein do not necessarily state or reflect those of the United States Government or any agency thereof. 


\section{DISCLAIMER}

Portions of this document may be illegible in electronic image products. Images are produced from the best available original document. 


\begin{abstract}
Radiochemical characterization data are described for $\mathrm{UO}_{2}$ and $\mathrm{UO}_{2}$ plus $3 \mathrm{wt} \% \mathrm{Gd}_{2} \mathrm{O}_{3}$ commercial spent nuclear fuel taken from a series of Approved Testing Materials (ATMs). These full-length nuclear fuel rods include MLA091 of ATM-103, MKP070 of ATM-104, NBD095 and NBD131 of ATM-106, and ADN0206 of ATM-108. ATMs 103, 104, and 106 were all irradiated in the Calvert Cliffs Nuclear Power Plant (Reactor No.1), a pressurized-water reactor that used fuel fabricated by Combustion Engineering. ATM-108 was part of the same fuel bundle designated as ATM-105 and came from boiling-water reactor fuel fabricated by General Electric and irradiated in the Cooper Nuclear Power Plant. Rod average burnups and expected fission gas releases ranged from 2400 to $3700 \mathrm{GJ} / \mathrm{kgM}$. (25 to $40 \mathrm{Mwd} / \mathrm{kgM}$ ) and from less than $1 \%$ to greater than $10 \%$, respectively, depending on the specific ATM.
\end{abstract}

The radiochemical analyses included uranium and plutonium isotopes in the fuel, selected fission products in the fuel, fuel burnup, cesium and iodine on the inner surfaces of the cladding, ${ }^{14} \mathrm{C}$ in the fuel and cladding, and analyses of the gases released to the rod plenum. Supporting examinations such as fuel rod design and material descriptions, power histories, and gamma scans used for sectioning diagrams are also included.

These ATMs were examined as part of the Materials Characterization Center Program conducted at Pacific Northwest Laboratory provide a source of well-characterized spent fuel for testing in support of the U.S. Department of Energy Office of Civilian Radioactive Waste Management Program. 



\section{Summary}

Radiochemical analyses of the fuel, cladding, and samples of gas from the rod plenum are reported for five light-water reactor fuel rods fabricated by Combustion Engineering and General Electric. The fuel contained $\mathrm{UO}_{2}$ and $\mathrm{UO}_{2}$ plus $3 \mathrm{wt} \% \mathrm{Gd}_{2} \mathrm{O}_{3}$ taken from a series of ATMs. These full-length nuclear fuel rods include MLA091 of ATM-103, MKP070 of ATM-104, NBD095 and NBD131 of ATM-106, and ADN0206 of ATM-108. Hydrogen in the cladding from Rod G13 of ATM-101 are also reported.

Results of the burnup analyses and apparent fission gas releases are consistent with previous data for Rods MLA091, MKP707, NBD095, and NBD131, all of which were fabricated by C-E. Approximate end-of-life, rod-averaged burnups for these rods were $28,38,40$, and $46 \mathrm{MWd} / \mathrm{kgM}$, respectively. Apparent fission gas releases to the rod plenum were $<1 \%$ for Rods MLA091 and MKP070, about 7\% for Rod NBD095, and about 18\% for Rod NBD131. Rod ADN0206, (with 3 wt\% gadolinia in the as-fabricated fuel rod) had a end-of-life, rod-averaged burnup of about 24 $\mathrm{MWd} / \mathrm{kgm}$, and unexpectedly, moderate fission gas release of possibly $9 \%$. Data for hydrogen is the cladding of Rod G13 from ATM-101 indicates hydrogen content increased by about 200\% from the bottom to the top of the rod. Except for the fission gas release in Rod ADN0206, the burnups and fission gas releases were consistent with previous results for other fuel rods from these ATMs.

Extensive additional data has been published for these ATMS, including fuel burnup, the isotopes of uranium and plutonium, and specific nuclides such as ${ }^{79} \mathrm{Se},{ }^{90} \mathrm{Sr},{ }^{99} \mathrm{Tc},{ }^{126} \mathrm{Sn},{ }^{135} \mathrm{Cs},{ }^{137} \mathrm{Cs},{ }^{237} \mathrm{~Np}$, ${ }^{241} \mathrm{Am}$, and ${ }^{243} \mathrm{Cm}$ plus ${ }^{244} \mathrm{Cm}$. The amount of ${ }^{129} \mathrm{I},{ }^{14} \mathrm{C},{ }^{135} \mathrm{Cs}$, and ${ }^{137} \mathrm{Cs}$ in the fuel was also determined for most of the rods. Data were also provided for cesium on the exterior and interior surfaces of the cladding, iodine on the interior surfaces of the cladding, and total ${ }^{14} \mathrm{C}$ in the cladding. No comparison of these data with previous results for other rods from the same ATMs have been made; however, the data base for these fuels has significantly expanded.

These data were all obtained in accordance with the quality assurance requirements of Impact Level I under PNL-MA-70 and meet the needs of NQA-1 quality assurance. All work was obtained other issuance of statements of work, followed by specific requests for analytical service. The results have been obtained by trained staff with the necessary verifications and recording of the data. 



\section{Acknowledgments}

Characterization of these additional spent fuel rods was achieved through the efforts of many people. The authors extend their appreciation to the individuals who provided valuable assistance in conducting these analyses, including R. S. Holeman and L. J. Dunn, who conducted the in-cell fuel rod gamma scanning, fission gas sampling, and fuel rod sectioning operations; and $\mathrm{W}$. Y. Matsumoto, D. L. Baldwin, M. W. Goheen, L. S. Kellogg, and many technicians who conducted radiochemical analyses.

The authors would also like to thank M. A. Showalter, whose editorial assistance is sincerely appreciated; W. R. Standley of TRW's Environmental Waste and Safety Systems, the management and operating contractor for the Office of Civilian Radioactive Waste Management Program; and B. D. Reid of Pacific Northwest Laboratory for his programmatic support. 


\section{Acronymns}

$\begin{array}{ll}\text { ATM } & \text { Approved Testing Material } \\ \text { BG\&E } & \text { Baltimore Gas and Electric } \\ \text { BOL } & \text { beginning of life } \\ \text { BWR } & \text { boiling-water reactor } \\ \text { C: } & \text { Curie } \\ \text { CC-1 } & \text { Calvert Cliffs Nuclear Reactor No. } 1 \\ \text { C-E } & \text { Combustion Engineering } \\ \text { Cooper } & \text { Cooper Nuclear Power Plant } \\ \text { d/m/cm } & \text { disintegrations/minute/centimeter squared } \\ \text { DOE } & \text { U.S. Department of Energy } \\ \text { EOL } & \text { end of life } \\ \text { GE } & \text { General Electric } \\ \text { guel } & \text { 1 gram of initial fuel material }\left(\mathrm{VO}_{2}\right) \\ \text { gZr } & 1 \text { gram of Zircalog cladding } \\ \text { LHGRs } & \text { linear heat generation rates } \\ \text { MCC } & \text { Materials Characterization Center } \\ \text { MWd/kgM megawatt-day per kilogram of initial heavy metal in the fuel } \\ \text { MWd/mtm megawatt-day per metric ton of } \text { initial.heavy metal in the fuel } \\ \text { OCRWM } & \text { Office of Civilian Radioactive Waste Management } \\ \text { PNL } & \text { Pacific Northwest Laboratory } \\ \text { PWR } & \text { pressurized-water reactor }\end{array}$


, 


\section{Contents}

Acronymns

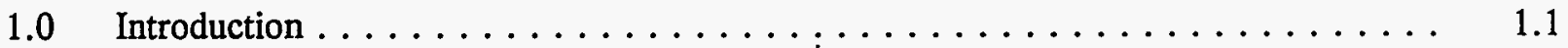

2.0 Design and Power Histories for ATMs 103, 104, 106, and $108 \ldots \ldots \ldots$

2.1 ATM-103 design and Power History $\ldots \ldots \ldots \ldots \ldots \ldots \ldots \ldots \ldots$

2.1.1 Assembly, Fuel Rod, and Pellet Description . . . . . . . . . . 2.1

2.1 .2 Irradiation History $\ldots \ldots \ldots \ldots \ldots \ldots \ldots \ldots \ldots \ldots \ldots \ldots \ldots$

$2.2 \quad$ ATM-104 Design and Power History $\ldots \ldots \ldots \ldots \ldots \ldots \ldots \ldots$

2.2.1 Assembly, Fuel Rod, and Pellet Description . . . . . . . . 2.8

2.2 .2 Irradiation History $\ldots \ldots \ldots \ldots \ldots \ldots \ldots \ldots \ldots \ldots \ldots \ldots$

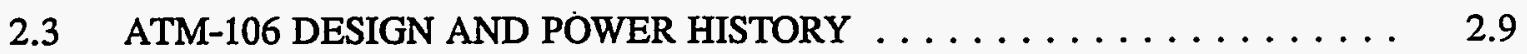

2.3.1 Assembly, Fuel Rod, and Pellet Description . . . . . . . . . . 2.14

2.3.2 Irradiation History $\ldots \ldots \ldots \ldots \ldots \ldots \ldots \ldots \ldots \ldots \ldots$

2.4 ATM-108 Design and Power History $\ldots \ldots \ldots \ldots \ldots \ldots \ldots \ldots \ldots$

2.4.1 Fuel Bundle and Rod Description . . . . . . . . . . . 2.15

2.4 .2 Irradiation History $\ldots \ldots \ldots \ldots \ldots \ldots \ldots \ldots \ldots \ldots \ldots \ldots \ldots \ldots$

3.0 Gamma Scans and Rod Sectioning $\ldots \ldots \ldots \ldots \ldots \ldots \ldots \ldots \ldots \ldots \ldots \ldots \ldots$

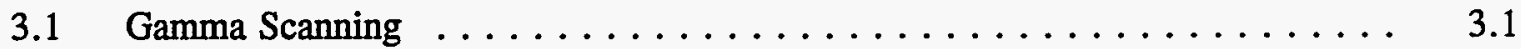

3.2 Rod Sectioning and Sample Selection $\ldots \ldots \ldots \ldots \ldots \ldots \ldots \ldots \ldots$

4.0 Radiochemical Analyses $\ldots \ldots \ldots \ldots \ldots \ldots \ldots \ldots \ldots \ldots \ldots \ldots \ldots$

4.1 Cladding Analyses $\ldots \ldots \ldots \ldots \ldots \ldots \ldots \ldots \ldots \ldots \ldots \ldots \ldots$

4.2 Fuel Analyses $\ldots \ldots \ldots \ldots \ldots \ldots \ldots \ldots \ldots \ldots \ldots \ldots \ldots \ldots \ldots$

4.3 Gas Analyses $\ldots \ldots \ldots \ldots \ldots \ldots \ldots \ldots \ldots \ldots \ldots \ldots \ldots \ldots \ldots$ 
Appendix A - Gamma Scans and Sectioning Diagrams

A. 1

Appendix B -Radiochemical Analyses

B. 1 


\section{Figures}

2.1 Fuel Assembly Schematic for ATMs 103, 104, and $106 \ldots \ldots \ldots \ldots \ldots$

2.2 ATM-103 and ATM-104 Pellet and Fuel Rod Dimensions $\ldots \ldots \ldots \ldots \ldots \ldots$

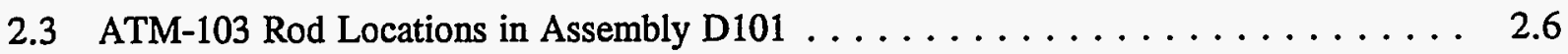

2.4 Power History for Rod MLA098 from Assembly D101 . . . . . . . . . . . . 2.7

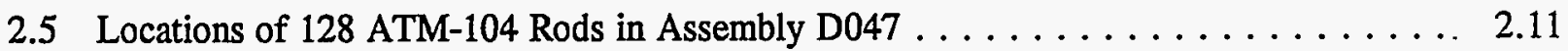

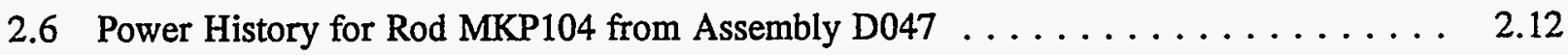

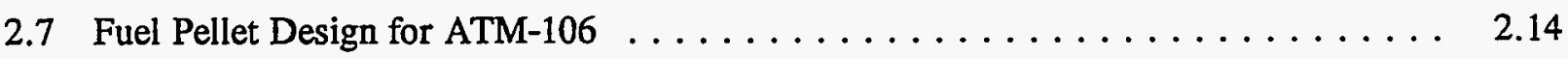

2.8 Locations of Twenty Rods in Assembly BT03 $\ldots \ldots \ldots \ldots \ldots \ldots \ldots \ldots$

2.9 Approximate Power History for Rod NBD107 from Assembly BT03 $\ldots \ldots \ldots \ldots$

2.10 General Electric $7 \times 7$ Fuel Bundle for ATM-108 $\ldots \ldots \ldots \ldots \ldots$

2.11 Location of Different Types of Fuel Rods in Bundles . . . . . . . . . . . . . 2.21

2.12 Gadolinia Loading in Type 5, Type 6, and Type 7 Rods in ATM-108 . . . . . . . 2.23

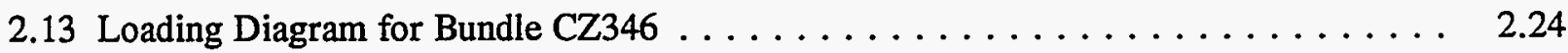




\section{Tables}

$1.1 \quad$ Summary of Spent Fuel ATMs $\ldots \ldots \ldots \ldots \ldots \ldots \ldots \ldots \ldots \ldots \ldots \ldots \ldots \ldots$

$2.1 \quad$ ATM-103 Fuel Pellet Certification Data $\ldots \ldots \ldots \ldots \ldots \ldots \ldots \ldots \ldots$

2.2 ATM-103 Cladding Certification Data $\ldots \ldots \ldots \ldots \ldots \ldots \ldots \ldots \ldots \ldots \ldots \ldots \ldots$

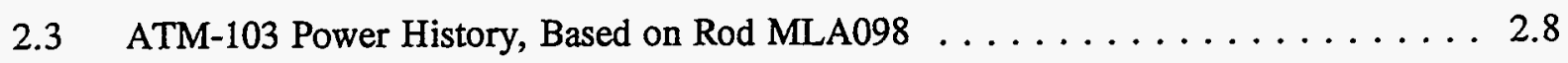

2.4 ATM-104 Fuel Pellet Certification Data $\ldots \ldots \ldots \ldots \ldots \ldots \ldots \ldots . .9 \ldots$

2.5 ATM-104 Cladding Certification Data $\ldots \ldots \ldots \ldots \ldots \ldots \ldots \ldots \ldots \ldots \ldots \ldots \ldots \ldots$

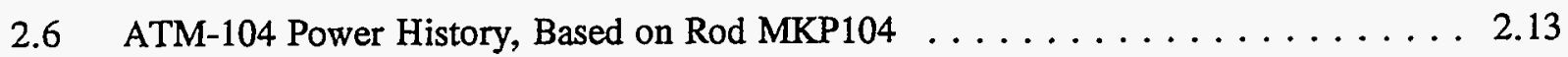

2.7 ATM-106 Fuel Pellet Certification Data $\ldots \ldots \ldots \ldots \ldots \ldots \ldots \ldots \ldots \ldots \ldots \ldots$

2.8 ATM-106 Fuel Rod Cladding Certification Data $\ldots \ldots \ldots \ldots \ldots \ldots \ldots \ldots$

2.9 Detailed Power History for Rod NBD $107 \ldots \ldots \ldots \ldots \ldots \ldots \ldots \ldots \ldots$

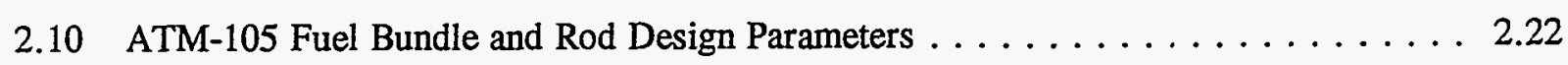

2.11 Fuel Composition Assumed for ATM-105 Fuel Rods $\ldots \ldots \ldots \ldots \ldots \ldots \ldots$

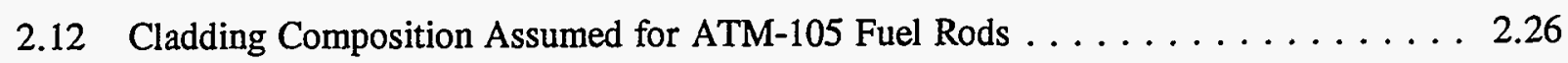

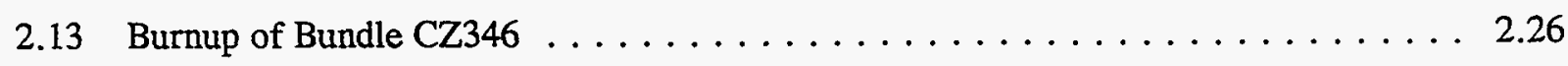

4.1 Summary of Section Numbers for Rods Analyzed $\ldots \ldots \ldots \ldots \ldots \ldots \ldots .2$

4.2 Description of Radiochemical Analysis Procedures for Cladding Samples . . . . . . 4.3

4.3 Description of Radiochemical Analyses Procedures for Fuel Samples $\ldots \ldots \ldots 4.4$

4.4 Estimated Fission Gas Releases from Characterized Rods . . . . . . . . . . 4.6 


\subsection{Introduction}

The Materials Characterization Center (MCC) at Pacific Northwest Laboratory (PNL) ${ }^{(a)}$ has provided spent fuel test material and samples for laboratory investigations of nuclear waste forms by the U.S. Department of Energy (DOE) Office of Civilian Radioactive Waste Management (OCRWM) Program. This report provides previously unpublished radiochemical data obtained from characterization conducted for Rod MLA091 of Approved Testing Material-103 (ATM-103), Rod MKP070 of ATM-104, Rods NBD095 and NBD131 of ATM-106, and Rod ADN0206 of ATM-108. These rods came from a series of six spent fuel ATMs characterized to support investigations of spent nuclear fuel disposal. Previously reported data are provided for ATM-101 (Barner 1985), for Rod MLA098 of ATM-103 (Guenther et al. 1988a), for Rod MKP109 of ATM-104 (Guenther et al. 1991a), for Rods ADD2966 and ADD2974 of ATM-105 (Guenther et al. 1990), and for NBD107 of ATM-106 (Guenther et al. 1988b). These characterizations were conducted at the Hanford Site in Richland, Washington. A summary of the general characteristics of the spent fuel ATMs is provided in Table 1.1.

Table 1.1. Summary of Spent Fuel ATMs (Guenther et al. 1991a)

\begin{tabular}{|c|c|c|c|c|c|}
\hline ATM & Fuel Type & Reactor & Burnup Range & Range of & No. of Rods \\
\hline 101 & PWR & $\begin{array}{l}\text { H. B. Robinson, } \\
\text { No. } 1\end{array}$ & $16-32$ & $0.2-0.3$ & $\begin{array}{l}9 \text { as } 27 \\
1.2-\mathrm{m}(4-\mathrm{ft}) \\
\text { segments }^{(b)}\end{array}$ \\
\hline 103 & PWR & $\begin{array}{l}\text { Calvert Cliffs, } \\
\text { No. } 1\end{array}$ & $13-33$ & 0.25 & 176 full length \\
\hline 104 & PWR & $\begin{array}{l}\text { Calvert Cliffs, } \\
\text { No. } 1\end{array}$ & $26-44$ & $0.4-1.1$ & 128 full length \\
\hline 105 & BWR & Cooper & $18-34$ & $0.6-7.9$ & 88 full length \\
\hline 106 & PWR & $\begin{array}{l}\text { Calvert Cliffs, } \\
\text { No. } 1\end{array}$ & $29-47$ & $7.8-18$ & 20 full length \\
\hline 108 & BWR & Cooper & $\sim 15-26$ & $\sim 9$ & 10 full length \\
\hline
\end{tabular}

(a) Range of rod average values measured in the fuel rods examined.

(b) ATM-101 rods were cut in three sections prior to shipment to Hanford. These sections were denoted as bottom (B), center (C), or top (T).

(a) Operated by Battelle Memorial Institute for the U.S. Department of Energy. 
ATM-103 was selected as a representative moderate-burnup $\mathrm{UO}_{2}$ fuel, averaging about $2600 \mathrm{GJ} / \mathrm{kgM}$ (30 MWd $/ \mathrm{kgM}$ ), and was expected to have had only minor fission gas release from the $\mathrm{UO}_{2}$ fuel during irradiation. This fuel was fabricated by Combustion Engineering (C-E) and irradiated in the Calvert Cliffs Nuclear Reactor No. 1 (CC-1), a pressurized-water reactor (PWR) operated by Baltimore Gas and Electric (BG\&E). The 176 full-length fuel rods from Assembly D101 comprised ATM-103. ATM-101 was also a moderate-burnup, low-fission gas release fuel, but was fabricated by Westinghouse (Barner 1985).

ATM-104 has $\mathrm{UO}_{2}$-fueled rods with a moderately high burnup of about $3700 \mathrm{GJ} / \mathrm{kgM}$ $(43 \mathrm{MWd} / \mathrm{kgM})$. These rods were also expected to have only minor fission gas release from the $\mathrm{UO}_{2}$ fuel during irradiation and were fabricated by C-E and irradiated in the CC-1 PWR. ATM-104 consisted of 128 full-length fuel rods from Assembly D047. Of the original 176 rods irradiated in Assembly D047, 41 rods were removed for other uses by BG\&E. The remaining 135 rods were received by the MCC, but seven of these rods had insufficient data on fuel fabrication specifications to be included as part of ATM-104. The 128 ATM-104 rods were selected for characterization because they had moderately high burnup and because they were manufactured by the same vendor and irradiated in the same reactor as ATM-103 (moderate burnup, low fission gas release) and ATM-106 (moderately high burnup, high fission gas release).

Fuel rods from ATM-106 had a moderately high burnup of about $3700 \mathrm{GJ} / \mathrm{kgM}$ (43 MWd/kgM) and were expected to have fission gas release of about $10 \%$ from the $\mathrm{UO}_{2}$ fuel during irradiation. These fuel rods were fabricated by C-E and irradiated in the CC-1 PWR. Twenty full-length fuel rods from Assembly BT03 comprised ATM-106. The ATM-106 rods were removed from BT03, reinserted into unused locations in the assembly containing the ATM-104 rods, and shipped to the Hanford Site. The remaining fuel rods in Assembly BT03 were removed for other purposes by BG\&E. ATM-106 fuel was selected for characterization because it had moderately high burnup and high fission gas release was expected in these rods.

The ATM-108 rods were actually part of two fuel bundles comprising ATM-105 that had $\mathrm{UO}_{2}$ fueled and $\mathrm{UO}_{2}-\mathrm{Gd}_{2} \mathrm{O}_{3}$-fueled rods with moderate burnup, estimated to average about $2400 \mathrm{GJ} / \mathrm{kgM}$ (28 MWd/kgM). The fuel bundles containing ATM-108 and ATM-105 fuel rods were fabricated by General Electric (GE) and irradiated in the Cooper Nuclear Power Plant (Cooper), a boiling-water reactor (BWR) operated by the Nebraska Public Power District. There were several fuel rod designs in the GE fuel bundles. Five of the fuel rods from each of Bundles CZ346 and CZ348 contained $\mathrm{UO}_{2}$ and $\mathrm{Gd}_{2} \mathrm{O}_{3}$ and were designated ATM-108, with the remaining rods comprising ATM-105; the rods were not removed from the bundles unless they were examined. Because of gadolia in the fuel and various designs for rods with gadolinia, no burnup estimates were provided by the vendor for the individual rods. The fuel rods in the two bundles were expected to have low release of the fission gas from the $\mathrm{UO}_{2}$ fuel during irradiation. Characterization of ATM-105 and ATM-108 was initiated because a significant portion of spent fuel in the U.S. comes from BWRs. The results of the ATM-105 characterization reported by Guenther et al. (1991b) can be compared with the burnup data and limited isotopic analyses available for ATM-108. Only gamma scanning, fuel burnup, and metallography were conducted on Rod ADN0206 of ATM-108. 
The MCC spent fuel ATMs were selected to represent typical end-of-life (EOL) fuel conditions for their generation of fuel rods, potential extremes in EOL spent fuel conditions, or differences between PWR and BWR spent fuel from U.S. commercial nuclear reactors. This report presents the results of radiochemical analyses conducted on the fuel, cladding, and the plenum gases of spent fuel rods MLA091, MKP070, NBD095, NBD131, and ADN0206. Section 2.0 provides information on the assembly and fuel rod designs and the power histories for each ATM. Section 3.0 provides a brief description of the gamma scanning and sectioning diagrams. The results of the radiochemical analyses are discussed in Section 4.0 , including ${ }^{14} \mathrm{C}$ in the cladding; ${ }^{135} \mathrm{Cs},{ }^{137} \mathrm{Cs}$, and ${ }^{129} \mathrm{I}$ on the cladding interior surface; fuel burnup; and radiochemical analyses of selected isotopes in the fuel. 


\subsection{Design and Power Histories for ATMs 103, 104, 106, and 108}

Available design characteristics and power histories are provided for ATMs 103, 104, 106, and 108 in Sections 2.1, 2.2, 2.3, and 2.4, respectively. Details are provided for fuel assembly design, fuel rod and pellet designs, and as-fabricated materials properties. Details on ATM-101 can be found in Barner (1985).

\subsection{ATM-103 Design and Power History}

ATM-103 consists of one fuel assembly (D101) irradiated for three cycles in the CC-1 PWR operated by BG\&E and located outside Lusby, Maryland. The fuel assembly was discharged October 18, 1980 and transported from the reactor cooling basin to PNL in September 1985. Information is provided in Subsections 2.1.1 and 2.1.2 for the assembly and rod design, fuel and pellet initial composition, and power history during irradiation. This information is taken from Guenther et al. (1988a), in which the completed characterization of Rod MLA098 of ATM-103 is described.

\subsubsection{Assembly, Fuel Rod, and Pellet Description}

Assembly D101 is a standard C-E $14 \times 14$ fuel assembly. This fuel assembly is constructed with five guide tubes that comprise its main structure. The upper- and lower- end fittings, together with eight spacer grids and the five guide tubes, form a structural cage to support the fuel rods (Figure 2.1). All structural components except the lower Inconel grid and the stainless steel upper- and lower- end fittings are fabricated from Zircaloy-4.

The fuel rod and pellet dimensions for ATM-103 are shown in Figure 2.2. All the fuel pellets were fabricated using a standard cold-pressing and sintering process. Certification data for the fuel pellets used in Assembly D101 are shown in Table 2.1. All ATM-103 fuel rods are clad with Zircaloy-4 tubing fabricated by Sandvik Special Metals, Lot Nos. 5FS72, 5FS73, and 5DM11. Fuel cladding certification data are listed in Table 2.2. Rod MLA091 was located in position D7 of Assembly D101 during irradiation, as shown in Figure 2.3.

\subsubsection{Irradiation History}

The ATM-103 rods were irradiated in Assembly D101 during Cycles 2, 3, and 4 of operation of CC-1 between March 22, 1977, and October 18, 1980. The core thermal-power rating of CC-1 was 2560 MWt from beginning-of-life (BOL) until midway through Cycle 2 (September 9, 1977) when a new license was issued to increase CC-1's power rating to $2700 \mathrm{MWt}$. Excluding for a period of about five months at reduced power during reactor Cycle 4, the reactor operated at full power during Cycles 2,3 , and 4 .

CC-1 contains 217 fuel assemblies. Linear heat generation rates (LHGRs) for specific fuel rods vary significantly from average LHGRs. For example, the core-average LHGR was relatively constant at about $20.3 \mathrm{~kW} / \mathrm{m}(6.2 \mathrm{~kW} / \mathrm{ft})$ during Cycles 2, 3, and 4, while the average LHGR in Rod MLA098 ranged from a high of about $23 \mathrm{~kW} / \mathrm{m}(7.1 \mathrm{~kW} / \mathrm{ft})$ at the beginning of Cycle 2 to a low of about 


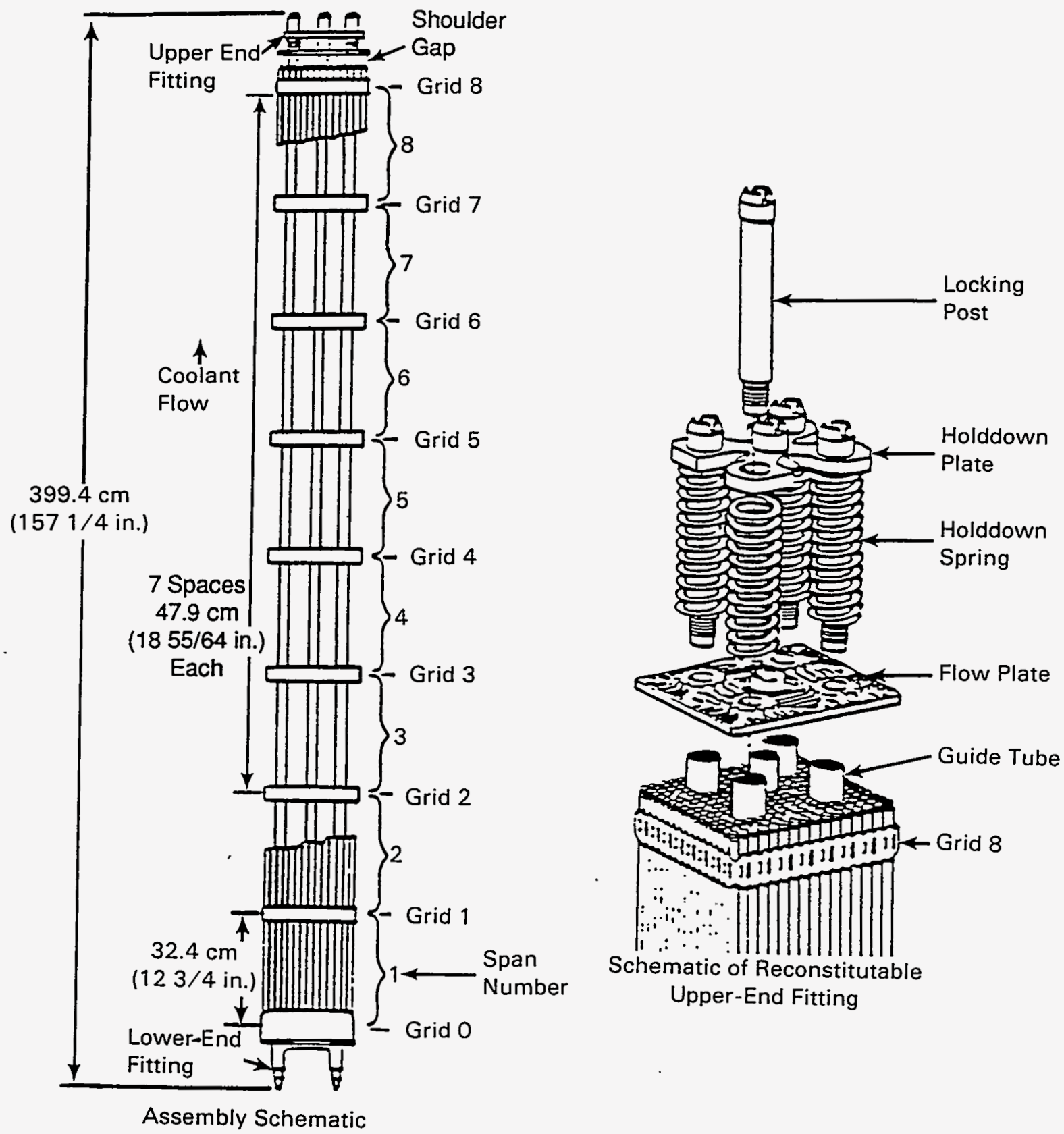

Figure 2.1. Fuel Assembly Schematic for ATMs 103, 104, and 106 (from Guenther et al. 1991a) 


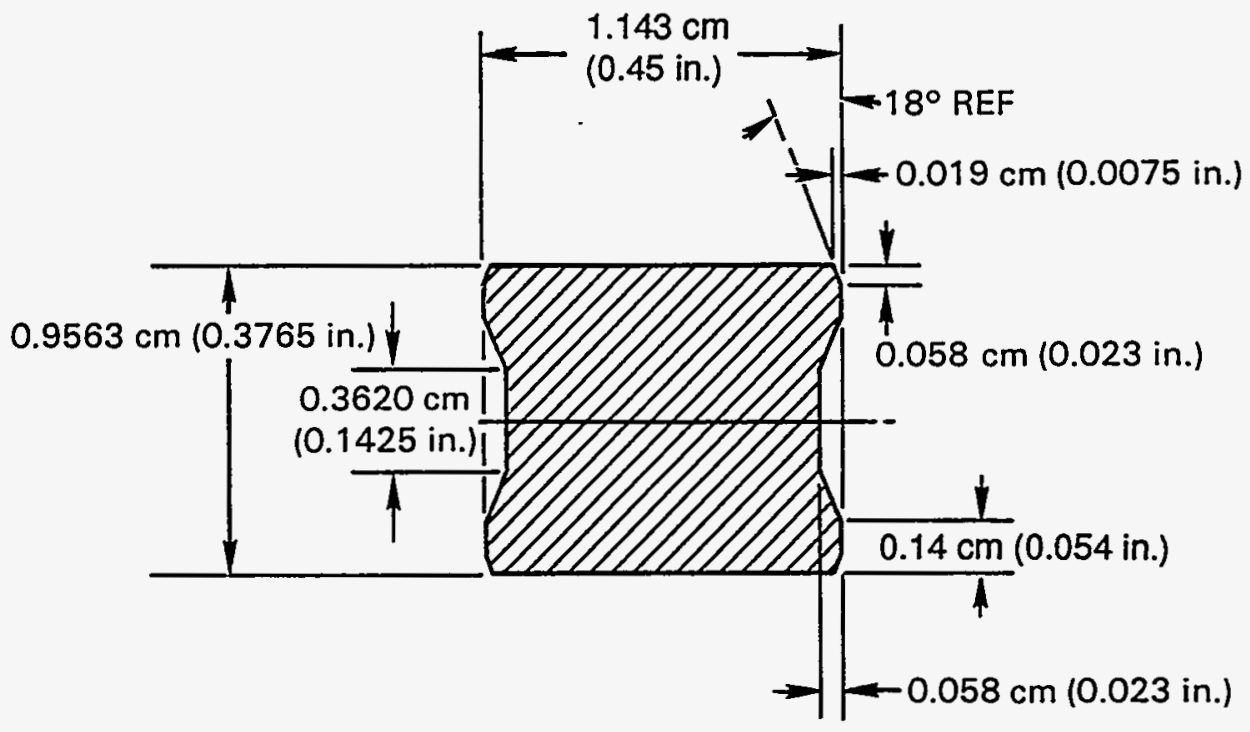

Fuel Pellet Schematic

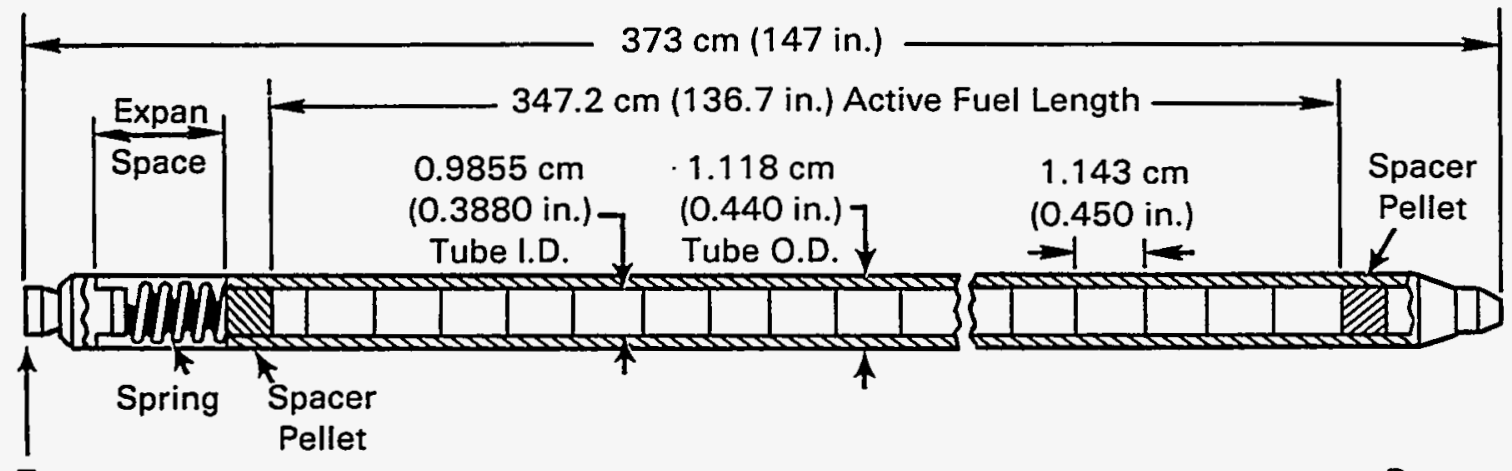

Top

(Reference Point for

Test Fuel Rod Schematic (Batch D)

Bottom

Gamma Scanning)

Figure 2.2. ATM-103 and ATM-104 Pellet and Fuel Rod Dimensions (from Guenther et al. 1991a) 
Table 2.1. ATM-103 Fuel Pellet Certification Data (Guenther et al. 1988a)

Chemical Attribute

\begin{tabular}{|c|c|c|c|}
\hline Chemical Attribute & \multicolumn{3}{|c|}{ Fuel Lot B-60-EB Analysis Results } \\
\hline Total uranium wt\% & 88.149 & 88.149 & 88.152 \\
\hline Carbon, ppm & 13 & 12 & 12 \\
\hline Nitrogen, pp & 28 & 28 & 17 \\
\hline Fluorine, ppm & $<5$ & $<5$ & $<5$ \\
\hline Chlorine \& fluorine, ppm & $<10$ & $<10$ & $<10$ \\
\hline Iron, $\mathrm{ppm}$ & 51 & 50 & 55 \\
\hline Silver, ppm & $<1$ & $<1$ & $<1$ \\
\hline $\left.\begin{array}{l}\text { Calcium, ppm } \\
\text { Aluminum, ppm } \\
\text { Silicon, ppm }\end{array}\right\}$ & $<121$ & $<120$ & $<121$ \\
\hline $\mathrm{O}: \mathrm{U}$ ratio & 2.000 & 2.000 & 2.000 \\
\hline Nickel, ppm & $<25$ & $<25$ & $<25$ \\
\hline Mass spec. analysis & & $2.72 \% 2$ & \\
\hline Density & & $10.34-10$ & $\mathrm{~cm}^{3}$ \\
\hline Grain size & & $\geq 5 \mu \mathrm{m}$ & \\
\hline $\begin{array}{l}18 \mathrm{~kW} / \mathrm{m}(5.5 \mathrm{~kW} / \mathrm{ft}) \text { at the } \\
\text { Figure } 2.4 \text {. The power hist } \\
\text { actual power in other rods i } \\
\text { however, burnups for a give } \\
\text { MLA098 appropriately adju }\end{array}$ & $\begin{array}{l}\text { Cycle } 4 \text {, as } \\
\text { cific to Rod } \\
\text { ably D101 w } \\
\text { rod or sampl } \\
\text { yield the des }\end{array}$ & $\begin{array}{l}0 x i m a t e \text { for } \\
098 \text { is giver } \\
\text { ry slightly d } \\
\text { y be calcula } \\
\text { end of life b }\end{array}$ & $\begin{array}{l}\text { LA098 in As } \\
\text { oular form in } \\
\text { ing on the act } \\
\text { ng the power }\end{array}$ \\
\hline 2.2 ATM-104 Design & Power Hi & & \\
\hline $\begin{array}{l}\text { ATM-104 consists of a } \\
\text { four cycles in CC-1. The as } \\
\text { to April } 1982 \text {, when it was } \\
\text { reactor cooling basin to PNI } \\
2.2 .2 \text { on the assembly and } \mathrm{r} \\
\text { irradiation. This informatio } \\
\text { terization of Rod MKP104 }\end{array}$ & $\begin{array}{l}\text { of one fuel } \\
\text { was fabrica } \\
\text { ged from the } \\
\text { ptember } 198 \\
\text { gn, fuel and } \\
\text { en from Gue } \\
\text { [-104 is desc }\end{array}$ & $\begin{array}{l}\text { bly (D047) } \\
\text { the mid-19 } \\
\text { tor. The fut } \\
\text { formation is } \\
\text { t initial com } \\
\text { et al. (199 }\end{array}$ & $\begin{array}{l}\text { ated by C-E } \\
\text { Id irradiated } \\
\text { mbly was tra } \\
\text { ded in Subse } \\
\text { in, and power } \\
\text { which the cor }\end{array}$ \\
\hline
\end{tabular}


Table 2.2. ATM-103 Cladding Certification Data (Guenther et al. 1988a)

\begin{tabular}{|c|c|c|c|c|c|c|}
\hline \multirow{2}{*}{$\begin{array}{l}\text { Fuel Assembly: D101 } \\
\text { Tensile Properties }\end{array}$} & \multicolumn{2}{|c|}{$\begin{array}{l}\text { ROD LOT: MLA } \\
\text { CLAD LOT: 5FS72 }\end{array}$} & \multicolumn{2}{|c|}{$\begin{array}{l}\text { ROD LOT: MLA } \\
\text { CLAD LOT: } 5 F S 73\end{array}$} & \multicolumn{2}{|c|}{$\begin{array}{l}\text { ROD LOT: MLA/MLB } \\
\text { CLAD LOT: 5DM11 }\end{array}$} \\
\hline & & & & & & \\
\hline Room UTS, psi & 100900 & 98600 & 98500 & 96800 & 98800 & 96000 \\
\hline $0.2 \% \mathrm{Ys}, \mathrm{psi}$ & 76200 & 73900 & 76400 & 75300 & 74500 & 74300 \\
\hline Elong. 2 in., $\%$ & 24 & 24 & 24 & 25 & 23 & 24 \\
\hline $750^{\circ} \mathrm{F}$ UTS, psi & 54000 & 51200 & 51500 & 49800 & 53400 & 50600 \\
\hline $0.2 \%$ YS, psi & 40700 & 37200 & 38900 & 37600 & 38500 & 36700 \\
\hline Elong. 2 in., \% & 32 & 33 & 33 & 33 & 30 & 32 \\
\hline \multicolumn{7}{|c|}{ Burst Test (closed end with mandrel at room temperature) } \\
\hline Pressure., psi & 17300 & 16800 & 17100 & 17100 & 17200 & 17100 \\
\hline Circ. Elong., \% & 17 & 19.7 & 20.6 & 23.7 & 21 & 21 \\
\hline \multicolumn{7}{|l|}{ Hydride Orientation } \\
\hline OD & 0.04 & 0.06 & 0.05 & 0.08 & 0.03 & 0.01 \\
\hline Fn Mid & 0.03 & 0.02 & 0.02 & 0.08 & 0.02 & 0.04 \\
\hline ID & 0.05 & 0.00 & 0.04 & 0.04 & 0.00 & 0.02 \\
\hline
\end{tabular}

Corrosion Test ( $3 \mathrm{day}, 750^{\circ} \mathrm{F}$ steam)

Sample $w t / d m^{2}$

Color

Std. $w t / \mathrm{dm}^{2}$

Std. No.

Sample wt/dm $\mathbf{m}^{2}$

Color

Chemical Analysis, ppm

Hydrogen

Nitrogen

Oxygen

Carbon

\begin{tabular}{l}
\multicolumn{1}{c}{ Etched } \\
\hline 12.7 \\
Lustrous Black
\end{tabular}

$\begin{array}{lll}14.7 & 12.8 \quad 11.9\end{array}$ C217(T) C218(C) C223(B)

\begin{tabular}{lc}
\multicolumn{2}{c}{ Etched } \\
\hline 12.9 & 13.1 \\
Lustrous Black
\end{tabular}

$14.7 \quad 12.8$

C217(T) C218(C) C223(B)

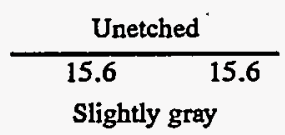

$\begin{array}{rr}15 & 14 \\ 31 & 24 \\ 1240 & 1240 \\ 124 & 106\end{array}$

12.0

12.0

$12.0 \quad 12.0$

$1100^{\circ} \mathrm{F}, 45 \mathrm{~min}$.

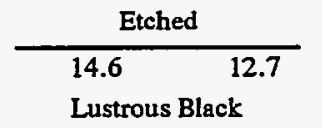

Lustrous Black

$\begin{array}{lll}12.5 & 12.8 \quad 15.0\end{array}$

C312(T) C348(C) C371(B)

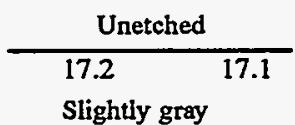

Slightly gray

$\begin{array}{rr}9 & 14 \\ 31 & 37 \\ 1358 & 1313 \\ 178 & 179\end{array}$

Grain Size

Long. ASTM

Trans. ASTM

Recrystallization Data

Surface Roughness
$12.0 \quad 11.5$

$11.5 \quad 12.0$

$1100^{\circ} \mathrm{F}, 45 \mathrm{~min}$.
$12.0 \quad 12.0$

$12.0 \quad 12.0$

$1100^{\circ} \mathrm{F}, 45 \mathrm{~min}$.

$\begin{array}{lllllll}\text { OD, RMS, microinch } & 20 & 20 & 18 & 19 & 18 & 18 \\ \text { ID, RMS, microinch } & 20 & 20 & 18 & 19 & 18 & 18\end{array}$




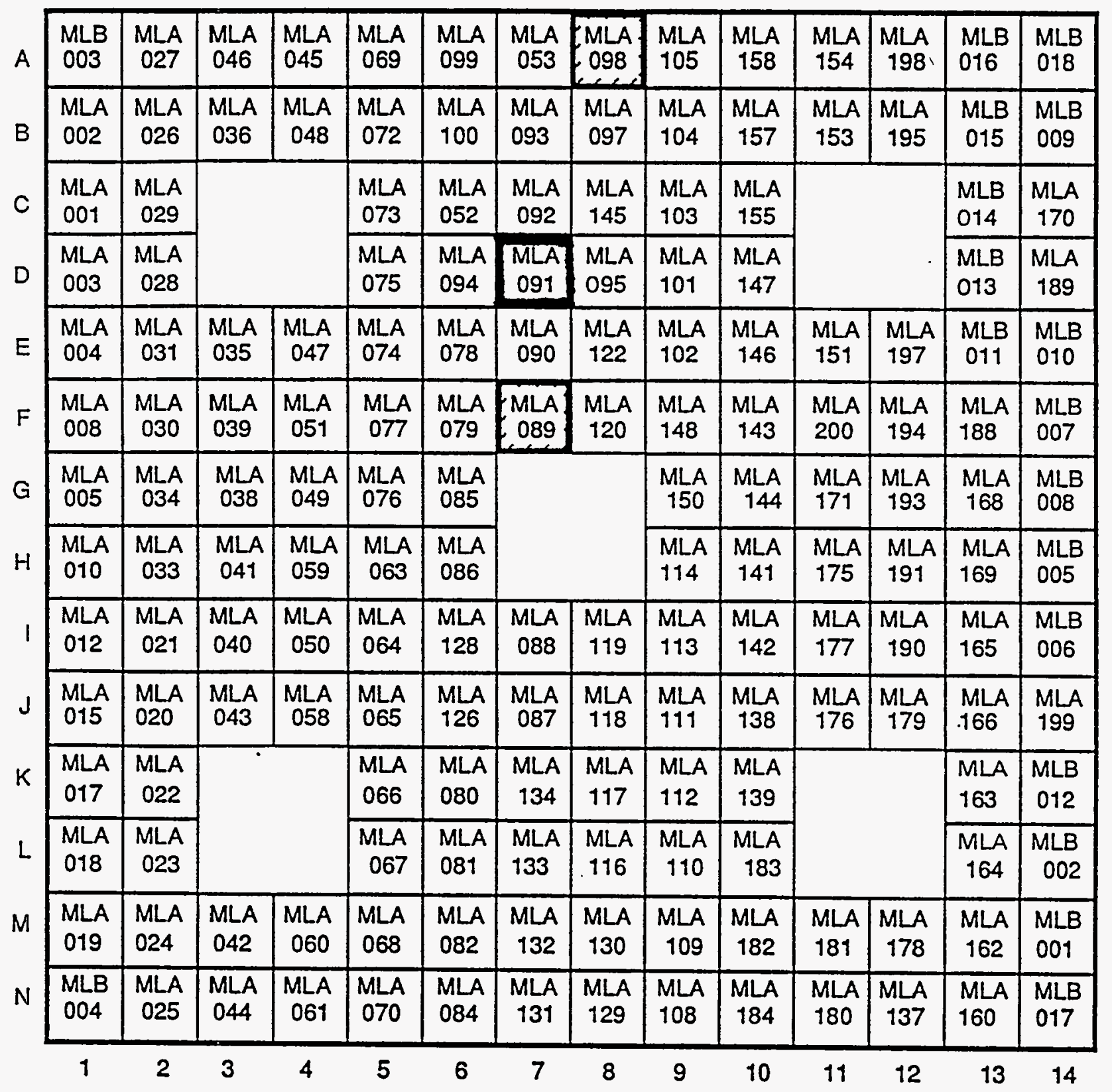

Figure 2.3. ATM-103 Rod Locations in Assembly D101 (characterized rods denoted in highlighted boxes) (Guenther et al. 1988a) 


\begin{tabular}{|l|c|c|c|}
\hline Cycle No. & 2 & 3 & 4 \\
\hline Start/End of Cycle & $3-22-77 / 1-28-78$ & $4-3-78 / 4-20-79$ & $7-10-79 / 10-18-80$ \\
\hline Cycle Duration & $\sim 10$ months & $\sim 12.5$ months & $\sim 15$ months \\
\hline $\begin{array}{l}\text { Cycle Burnup } \\
\text { GJ/kgM (MWd/kgM) }\end{array}$ & $848(9.82)$ & $855(9.90)$ & $871(10.08)$ \\
\hline $\begin{array}{l}\text { Cumulative Burnup } \\
\text { GJ/kgM (MWd/kgM) }\end{array}$ & $848(9.82)$ & $1704(19.72)$ & $2575(29.80)$ \\
\hline
\end{tabular}

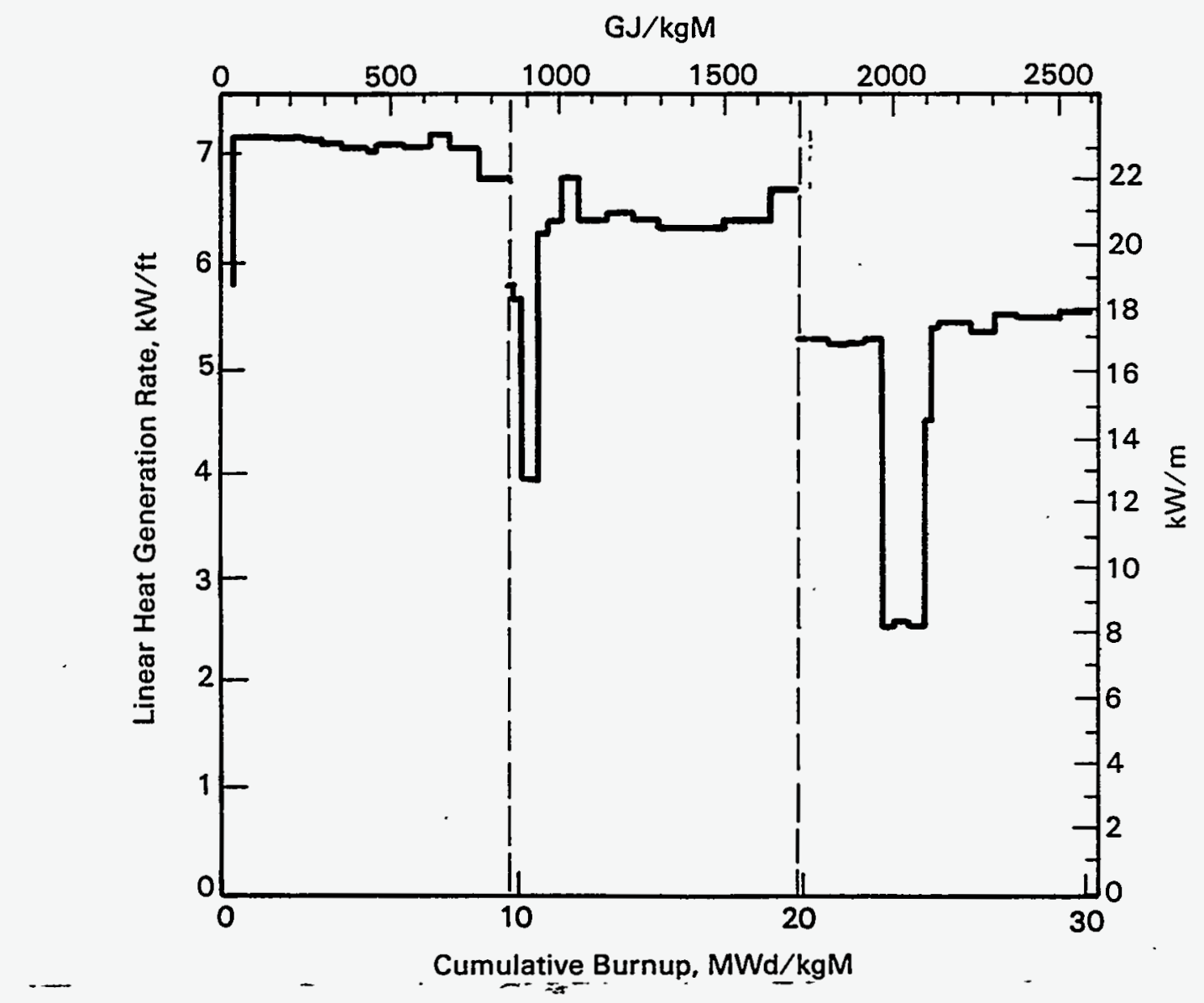

Figure 2.4. Power History for Rod MLA098 from Assembly D101 (from Guenther et al. 1988a) 
Table 2.3. ATM-103 Power History, Based on Rod MLA098 (Guenther et al. 1988a)

\begin{tabular}{|c|c|c|c|c|c|}
\hline \multicolumn{2}{|c|}{ Cycle 2} & \multicolumn{2}{|c|}{ Cycle $3^{(a)}$} & \multicolumn{2}{|c|}{ Cycle 4} \\
\hline $\begin{array}{c}\text { Time Interval } \\
\text { (Days) }\end{array}$ & $\begin{array}{c}\text { LHGR, kW/m } \\
(\mathrm{kW} / \mathrm{ft})\end{array}$ & $\begin{array}{c}\text { Time Interval } \\
\text { (Days) }\end{array}$ & $\begin{array}{c}\text { LHGR, kW/m } \\
(\mathrm{kW} / \mathrm{ft})\end{array}$ & $\begin{array}{c}\text { Time Interval } \\
\text { (Days) }\end{array}$ & $\begin{array}{c}\text { LHGR, kW/m } \\
(\mathrm{kW} / \mathrm{ft})\end{array}$ \\
\hline 7.1 & $19.1(5.81)$ & 6.8 & $19.1(5.83)$ & 47.0 & $17.4(5.30)$ \\
\hline 30.8 & $23.5(7.17)$ & 14.3 & $18.6(5.68)$ & 24.1 & $17.2(5.25)$ \\
\hline 16.4 & $23.5(7.17)$ & 19.5 & $13.1(3.98)$ & 22.5 & $17.3(5.26)$ \\
\hline 11.4 & $23.5(7.17)$ & 16.5 & $20.7(6.32)$ & 25.5 & $17.3(5.28)$ \\
\hline 12.5 & $23.5(7.17)$ & 16.1 & $21.1(6.42)$ & 30.7 & $8.4(2.56)$ \\
\hline 23.4 & $23.5(7.16)$ & 15.1 & $22.4(6.83)$ & 41.0 & $8.6(2.63)$ \\
\hline 22.8 & $23.4(7.14)$ & 38.8 & $21.1(6.43)$ & 50.1 & $8.6(2.61)$ \\
\hline 22.9 & $23.3(7.11)$ & 31.0 & $21.3(6.48)$ & 10.9 & $14.9(4.55)$ \\
\hline 8.5 & $23.3(7.09)$ & 31.6 & $21.1 \cdot(6.44)$ & 10.7 & $17.7(5.40)$ \\
\hline 31.4 & $23.5(7.16)$ & 31.6 & $20.9(6.37)$ & 45.1 & $17.9(5.45)$ \\
\hline 34.2 & $23.3(7.11)$ & 43.9 & $20.9(6.37)$ & 29.3 & $17.6(5.37)$ \\
\hline 16.6 & $23.7(7.22)$ & 61.7 & $21.1(6.43)$ & 28.0 & $18.1(5.51)$ \\
\hline 19.1 & $23.3(7.11)$ & 30.2 & $22.0(6.71)$ & 65.1 & $18.0(5.50)$ \\
\hline 12.8 & $23.5(7.15)$ & & & 35.7 & $18.2(5.54)$ \\
\hline 34.3 & $22.2(6.77)$ & & & & \\
\hline 1.9 & $22.2(6.78)$ & & & & \\
\hline
\end{tabular}

(a) Reactor was shut down for 25 days starting with day 270 of Cycle 3.

\subsubsection{Assembly, Fuel Rod, and Pellet Description}

The assembly, fuel rod, and pellet designs for ATM-104 were identical to those shown previously for ATM-103 in Figures 2.1 and 2.2. All of the fuel pellets were fabricated using a standard coldpressing and sintering process. The fuel pellet certification data for Assembly D047 are shown in Table 2.4. The 128 ATM-104 rods were fabricated from Fuel Lot B-71-GB; the seven remaining rods (NBD005, NBD067, NBD112, AHS040, AHS044, AHS060, and AHS077) were created from other fuel lots and were not scheduled for testing.

All ATM-104 rods are clad with Zircaloy-4 tubing fabricated by Sandvik Special Metals, Lot Numbers 5GD12, 5GD31, and 5FP65. Cladding certification data are listed in Table 2.5. Rod MKP070 was located in position D7 of Assembly D047, as shown in Figure 2.5.

\subsubsection{Irradiation History}

Assembly D047 was irradiated in Cycles 2, 3, 4, and 5 of operation of CC-1 between March 22, 1977, and April 17, 1982. The core thermal-power rating at CC-1 was $2560 \mathrm{MWt}$ from BOL until midway through Cycle 2 (September 9, 1977), when a new license was issued to increase CC-1's power rating to $2700 \mathrm{MWt}$. Like ATM-103 fuel, this assembly operated at reduced power for a period of five months during reactor Cycle 4. 
Table 2.4. ATM-104 Fuel Pellet Certification Data (Guenther et al. 1991a)

\begin{tabular}{|c|c|c|c|c|}
\hline Chemical Attribute & \multicolumn{4}{|c|}{ Fuel Lot B-71-GB Analysis Results } \\
\hline Total uranium, wt\% & 88.15 & 88.148 & 88.146 & 88.129 \\
\hline Carbon, ppm & 23 & 22 & 15 & $<10$ \\
\hline Nitrogen, ppm & 21 & 14 & 34 & 24 \\
\hline Fluorine, ppm & $<5$ & $<5$ & $<5$ & $<5$ \\
\hline Chlorine \& fluorine, ppm & $<10$ & $<10$ & $<10$ & $<10$ \\
\hline Iron, $\mathrm{ppm}$ & $<45$ & $<45$ & $<45$ & $<45$ \\
\hline Silver, $\mathrm{ppm}$ & $<1$ & $<1$ & $<1$ & $<1$ \\
\hline $\left.\begin{array}{l}\text { Calcium, ppm } \\
\text { Aluminum, ppm } \\
\text { Silicon, ppm }\end{array}\right\}$ & $<97$ & $<115$ & $<115$ & $<115$ \\
\hline $0: U$ ratio & 2.000 & 2.000 & 2.000 & 2.003 \\
\hline Nickel, ppm & $<25$ & $<25$ & $<25$ & $<25$ \\
\hline Mass spec. analysis & \multicolumn{4}{|c|}{$3.038 \%{ }^{235} \mathrm{U}$} \\
\hline Density & \multicolumn{4}{|c|}{$10.36-10.48 \mathrm{~g} / \mathrm{cm}^{3}$} \\
\hline Grain size & \multicolumn{4}{|c|}{$\geq 5 \mu \mathrm{m}$} \\
\hline
\end{tabular}

The core-average LHGR was relatively constant at about $20.3 \mathrm{~kW} / \mathrm{m}(6.2 \mathrm{~kW} / \mathrm{ft})$ during Cycles 2 , 3, 4, and 5, while the steady-state average LHGR in Rod MKP104 decreased from a high of about $24.1 \mathrm{~kW} / \mathrm{m}(7.4 \mathrm{~kW} / \mathrm{ft})$ at the beginning of Cycle 2 to a low of about $15.4 \mathrm{~kW} / \mathrm{m}(4 \mathrm{~kW} / \mathrm{ft})$ at the end of Cycle 5. Rod MKP104 (cell 19 in Figure 2.5) was expected to have an EOL burnup equivalent to the assembly average burnup according to calculations by C-E. The power history specific to Rod MKP104 in Assembly D047 is approximated in Figure 2.6 and is listed in tabular form in Table 2.6.

\subsection{ATM-106 Design and Power History}

ATM-106 consists of 20 rods from one fuel assembly (BT03) fabricated by C-E and irradiated for four cycles in the CC-1 PWR. The fuel assembly was discharged October 18, 1980. The ATM-106 fuel rods were transported from the reactor cooling basin to PNL in September 1985. Information is provided in Subsections 2.3.1 and 2.3.2 on the assembly and fuel rod design, fuel and pellet initial composition, and power history during irradiation. This information is taken from Guenther et al. (1988b) in which the completed characterization of Rod NBD107 of ATM-106 is described. 
Table 2.5. ATM-104 Cladding Certification Data (Guenther et al. 1991a)

\begin{tabular}{|c|c|c|c|c|c|c|}
\hline Fuel Assembly: D047 & \multicolumn{2}{|c|}{$\begin{array}{l}\text { ROD LOT: MKN } \\
\text { CLAD LOT: } 5 G D 12\end{array}$} & \multicolumn{2}{|c|}{$\begin{array}{c}\text { ROD LOT: } \\
\text { MKN/MKP } \\
\text { CLAD LOT: 5GD31 } \\
\end{array}$} & \multicolumn{2}{|c|}{$\begin{array}{l}\text { ROD LOT: MKP } \\
\text { CLAD LOT: } 5 \text { FFP65 }\end{array}$} \\
\hline \multicolumn{7}{|l|}{ Tensile Properties } \\
\hline Room UTS, psi & 101300 & 102500 & 100900 & 102200 & 102000 & 98700 \\
\hline $0.2 \%$ YS, psi & 75200 & 75600 & 74100 & 75800 & 76400 & 74400 \\
\hline Elong. 2 in., \% & 24 & 24 & 18 & 24 & 26 & 26 \\
\hline $750^{\circ} \mathrm{F}$ UTS, psi & 54800 & 54400 & 54700 & 55300 & 57700 & 53200 \\
\hline $0.2 \% \mathrm{Ys}, \mathrm{psi}$ & 41100 & 39200 & 41100 & 44500 & 40600 & 40200 \\
\hline Elong. 2 in., \% & 29 & 28 & 29 & 28 & 26 & 31 \\
\hline \multicolumn{7}{|c|}{ Burst Test (closed end with mandrel at room temperature) } \\
\hline Pressure., psi & 17800 & 17700 & 17900 & 18000 & 17800 & 17400 \\
\hline Circ. Elong., \% & 19 & 24 & 15 & 13 & 13 & 22 \\
\hline \multicolumn{7}{|l|}{ Hydride Orientation } \\
\hline OD & 0.16 & 0.05 & 0.03 & 0.02 & 0.06 & 0.05 \\
\hline Fn Mid & 0.01 & 0.04 & 0.02 & 0.05 & 0.07 & 0.10 \\
\hline ID & 0.02 & 0.03 & 0.03 & 0.01 & 0.03 & 0.00 \\
\hline
\end{tabular}

Corrosion Test ( 3 day, $750^{\circ} \mathrm{F}$ steam)

Sample wt/dm² Color

Std. $w t / d m^{2}$

Std. No.:

Sample $w t / \mathrm{dm}^{2}$

Color

Chemical Analysis, ppm

Hydrogen

Nitrogen

Oxygen

Carbon

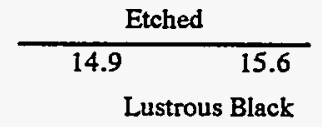

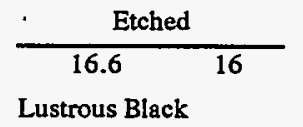

Lustrous Black

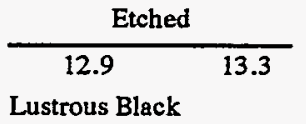

Lustrous Black

$\begin{array}{lll}15.6 & 15.9 & 12.9\end{array}$

Grain Size

Long. ASTM

Trans. ASTM

Recrystallization Data

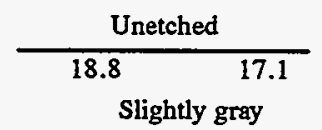

Slightly gray

$\begin{array}{rr}17 & 16 \\ 30 & 32 \\ 1200 & 1210 \\ 102 & 102\end{array}$

$\begin{array}{lr}11 & 12 \\ 11 & 12 \\ 1100^{\circ} \mathrm{F}, & 45 \mathrm{~min} .\end{array}$

\begin{tabular}{l} 
Unetched \\
\hline $17.6 \quad 18.8$ \\
Slightly gray
\end{tabular}

$\frac{\text { Unetched }}{17.3 \quad 16.7}$

$\begin{array}{rr}11 & 11 \\ 20 & 20 \\ 1100 & 1150 \\ 125 & 142\end{array}$

Surface Roughness

$\begin{array}{lllllll}\text { OD, RMS, microinch } & 18 & 18 & 18 & 20 & 18 & 18 \\ \text { ID, RMS, microinch } & 16 & 17 & 17 & 22 & 18 & 18\end{array}$




\begin{tabular}{|c|c|c|c|c|c|c|c|c|c|c|c|c|c|c|}
\hline & $\begin{array}{c}\text { MKP } \\
033 \\
\end{array}$ & $\begin{array}{c}\text { MKP } \\
030 \\
\end{array}$ & \begin{tabular}{|c|} 
MKP \\
061 \\
\end{tabular} & $\begin{array}{c}\text { MKP } \\
007 \\
\end{array}$ & $\begin{array}{c}\text { MKP } \\
034 \\
\end{array}$ & $\begin{array}{c}\text { MKP } \\
043 \\
\end{array}$ & $\begin{array}{c}\text { MKP } \\
081\end{array}$ & \begin{tabular}{|c} 
MKP \\
039
\end{tabular} & $\begin{array}{c}\text { MKP } \\
067 \\
\end{array}$ & $\begin{array}{c}\text { MKP } \\
080 \\
\end{array}$ & $\begin{array}{c}\text { MKP } \\
079 \\
\end{array}$ & $\begin{array}{c}\text { MKP } \\
092 \\
\end{array}$ & & $\begin{array}{c}\text { MKP } \\
029 \\
\end{array}$ \\
\hline & $\begin{array}{c}\text { MKP } \\
047 \\
\end{array}$ & $\begin{array}{c}\text { MKP } \\
051 \\
\end{array}$ & $\begin{array}{c}\text { MKP } \\
032 \\
\end{array}$ & $\begin{array}{c}\text { MKP } \\
017 \\
\end{array}$ & $\begin{array}{c}\text { MKP } \\
073 \\
\end{array}$ & & $\begin{array}{l}\text { MKP } \\
063\end{array}$ & $\begin{array}{r}\text { MKP } \\
106\end{array}$ & & $\begin{array}{c}\text { MKP } \\
118 \\
\end{array}$ & $\begin{array}{c}\text { MKP } \\
116 \\
\end{array}$ & $\begin{array}{c}\text { MKP } \\
005 \\
\end{array}$ & $\begin{array}{r}\text { MKP } \\
124 \\
\end{array}$ & \\
\hline & $\begin{array}{c}\text { MKN } \\
011 \\
\end{array}$ & $\begin{array}{c}\text { MKN } \\
160 \\
\end{array}$ & & & $\begin{array}{c}\text { MKP } \\
119 \\
\end{array}$ & $\begin{array}{c}\text { MKN } \\
047 \\
\end{array}$ & $\begin{array}{l}\text { MKP } \\
109\end{array}$ & $\begin{array}{c}\text { MKP } \\
054 \\
\end{array}$ & $\begin{array}{c}\text { MKP } \\
056 \\
\end{array}$ & $\begin{array}{c}\text { MKP } \\
112 \\
\end{array}$ & & \multirow{3}{*}{\begin{tabular}{|c} 
MKP \\
090 \\
\end{tabular}} & $\begin{array}{c}\text { MKP } \\
025 \\
\end{array}$ \\
\hline & $\begin{array}{c}\text { MKN } \\
002 \\
\end{array}$ & $\begin{array}{c}\text { MKP } \\
001 \\
\end{array}$ & & & $\begin{array}{c}\text { MKP } \\
042 \\
\end{array}$ & \begin{tabular}{|c} 
MKN \\
033 \\
\end{tabular} & $\begin{array}{l}\text { MKP } \\
070 \\
\end{array}$ & $\begin{array}{c}\text { MKP } \\
087 \\
\end{array}$ & $\begin{array}{r}\text { MKP } \\
045 \\
\end{array}$ & $\begin{array}{c}\text { MKP } \\
108 \\
\end{array}$ & & & & \\
\hline & $\begin{array}{c}\text { MKN } \\
150 \\
\end{array}$ & $\begin{array}{c}\text { M̈KP } \\
019 \\
\end{array}$ & \begin{tabular}{|c|} 
MKP \\
014 \\
\end{tabular} & $\begin{array}{c}\text { MKN } \\
104 \\
\end{array}$ & $\begin{array}{c}\text { MKP } \\
110 \\
\end{array}$ & $\begin{array}{c}\text { MKP } \\
150 \\
\end{array}$ & $\begin{array}{c}\text { MKP } \\
083 \\
\end{array}$ & $\begin{array}{c}\text { MKP } \\
103^{*} \\
\end{array}$ & $\begin{array}{c}\text { MKP } \\
026 \\
\end{array}$ & $\begin{array}{c}\text { MKP } \\
077 \\
\end{array}$ & & $\begin{array}{c}\text { MKP } \\
1.15 \\
\end{array}$ & & $\begin{array}{c}\text { MKP } \\
048 \\
\end{array}$ \\
\hline & $\begin{array}{c}\text { MKN } \\
139 \\
\end{array}$ & & \begin{tabular}{|c|} 
MKP \\
018 \\
\end{tabular} & $\begin{array}{c}\text { NBD } \\
112 \\
\end{array}$ & $\begin{array}{l}\text { MKP } \\
057 \\
\end{array}$ & $\begin{array}{c}\text { MKP } \\
060 \\
\end{array}$ & $\begin{array}{l}\text { MKP } \\
059 \\
\end{array}$ & $\begin{array}{c}\text { MKP } \\
.068 \\
\end{array}$ & $\begin{array}{c}\text { MKP } \\
101 . \\
\end{array}$ & $\begin{array}{c}\text { MKP } \\
096 \\
\end{array}$ & $\begin{array}{c}\text { NBD } \\
067 \\
\end{array}$ & & & \\
\hline & $\begin{array}{c}\text { MKP } \\
003 \\
\end{array}$ & $\begin{array}{c}\text { MKN } \\
073 \\
\end{array}$ & \begin{tabular}{|c|} 
MKP \\
013 \\
\end{tabular} & $\begin{array}{c}\text { MKP } \\
072 \\
\end{array}$ & $\begin{array}{c}\text { MKP } \\
050 \\
\end{array}$ & $\begin{array}{c}\text { MKP } \\
020 \\
\end{array}$ & & & $\begin{array}{c}\text { MKP } \\
069 \\
\end{array}$ & $\begin{array}{c}\text { MKP } \\
100 \\
\end{array}$ & & $\begin{array}{c}\text { MKP } \\
120 \\
\end{array}$ & & $\begin{array}{c}\text { MKP } \\
028\end{array}$ \\
\hline & $\begin{array}{c}\text { MKN } \\
153 \\
\end{array}$ & $\begin{array}{c}\text { MKP } \\
021 \\
\end{array}$ & \begin{tabular}{|c|} 
MKP \\
046 \\
\end{tabular} & $\begin{array}{c}\text { MKP } \\
075 \\
\end{array}$ & $\begin{array}{c}\text { MKP } \\
015 \\
\end{array}$ & \begin{tabular}{|c} 
MKP \\
011 \\
\end{tabular} & & & $\begin{array}{c}\text { MKP } \\
093 \\
\end{array}$ & & $\begin{array}{c}\text { MKP } \\
125 \\
\end{array}$ & $\begin{array}{c}\text { NBD } \\
005 \\
\end{array}$ & $\begin{array}{c}\text { MKP } \\
044 \\
\end{array}$ & \\
\hline & $\begin{array}{c}\text { MKP } \\
002 \\
\end{array}$ & \begin{tabular}{|c|} 
AHS \\
040 \\
\end{tabular} & \begin{tabular}{|c|} 
MKP \\
035 \\
\end{tabular} & $\begin{array}{c}\text { AHS } \\
044 \\
\end{array}$ & $\begin{array}{c}\text { MKP } \\
008 \\
\end{array}$ & $\begin{array}{c}\text { MKP } \\
041 \\
\end{array}$ & $\begin{array}{c}\text { MKP } \\
038 \\
\end{array}$ & $\begin{array}{c}\text { MKP } \\
058 \\
\end{array}$ & $\begin{array}{c}\text { MKP } \\
104 \\
\end{array}$ & $\begin{array}{c}\text { MKP } \\
111 \\
\end{array}$ & $\begin{array}{c}\text { AHS } \\
040 \\
\end{array}$ & $\begin{array}{c}\text { MKP } \\
121 \\
\end{array}$ & $\begin{array}{c}\text { MKP } \\
005 \\
\end{array}$ & $\begin{array}{c}\text { MKP } \\
053 \\
\end{array}$ \\
\hline & $\begin{array}{r}\text { MKP } \\
076 \\
\end{array}$ & $\begin{array}{c}\text { MKP } \\
071 \\
\end{array}$ & $\begin{array}{c}\text { MKP } \\
009 \\
\end{array}$ & $\begin{array}{c}\text { MKP } \\
036 \\
\end{array}$ & $\begin{array}{r}\text { MKP } \\
004 \\
\end{array}$ & $\begin{array}{c}\text { MKP } \\
010 \\
\end{array}$ & \begin{tabular}{|c|} 
MKP \\
086 \\
\end{tabular} & $\begin{array}{c}\text { MKP } \\
126 \\
\end{array}$ & $\begin{array}{c}\text { MKP } \\
085 \\
\end{array}$ & & $\begin{array}{c}\text { MKP } \\
102 \\
\end{array}$ & & $\begin{array}{c}\text { MKP } \\
127 \\
\end{array}$ & \\
\hline & $\begin{array}{r}\text { MKP } \\
037 \\
\end{array}$ & $\begin{array}{c}\text { MKP } \\
040 \\
\end{array}$ & & & - & $\begin{array}{c}\text { MKP } \\
062 \\
\end{array}$ & & \begin{tabular}{|c|} 
MKP \\
117 \\
\end{tabular} & $\begin{array}{c}\text { AHS } \\
077\end{array}$ & $\begin{array}{c}\text { MKP } \\
105 \\
\end{array}$ & & & & $\begin{array}{c}\text { MKP } \\
024 \\
\end{array}$ \\
\hline & \begin{tabular}{|c|} 
MKP \\
184 \\
\end{tabular} & & & & $\begin{array}{c}\text { MKP } \\
022 \\
\end{array}$ & & $\begin{array}{c}\text { MKP } \\
052 \\
\end{array}$ & & $\begin{array}{r}\text { MKP } \\
084 \\
\end{array}$ & & & & $\begin{array}{c}\text { MKP } \\
082 \\
\end{array}$ & \\
\hline & & \begin{tabular}{|c|} 
MKP \\
016 \\
\end{tabular} & & $\begin{array}{c}\text { MKP } \\
031 \\
\end{array}$ & & & & $\begin{array}{c}\text { MKP } \\
065 \\
\end{array}$ & $\begin{array}{c}\text { AHS } \\
060 \\
\end{array}$ & $\begin{array}{l}\text { MKP } \\
074 \\
\end{array}$ & & $\begin{array}{c}\text { MKP } \\
122 \\
\end{array}$ & & $\begin{array}{c}\text { MKP } \\
012 \\
\end{array}$ \\
\hline & \begin{tabular}{|c|} 
MKN \\
169 \\
\end{tabular} & & \begin{tabular}{c|} 
MKP \\
023 \\
\end{tabular} & & $\begin{array}{c}\text { MKP } \\
078 \\
\end{array}$ & & $\begin{array}{c}\text { MKP } \\
064\end{array}$ & & $\begin{array}{r}\text { MKP } \\
107 \\
\end{array}$ & & $\begin{array}{c}\text { MKP } \\
091 \\
\end{array}$ & & $\begin{array}{c}\text { MKP } \\
099 \\
\end{array}$ & \\
\hline & 1 & 2 & 3 & 4 & 5 & 6 & 7 & 8 & 9 & 10 & 11 & 12 & 13 & 14 \\
\hline
\end{tabular}

R9004195.1

Figure 2.5. Locations of 128 ATM-104 Rods in Assembly D047 (characterized rods denoted in highlighted boxes) (Guenther et al. 1991a) 


\begin{tabular}{|l|c|c|c|c|}
\hline Cycle No. & 2 & 3 & 4 & 5 \\
\hline Start/End of Cycle & $3-22-77 / 1-22-78$ & $4-3-78 / 4-20-79$ & $7-10-79 / 10-18-80$ & $1-11-81 / 4-17-82$ \\
\hline Cycle Duration & $\sim 10$ months & -12.5 months & $\sim 15$ months & -15.5 months \\
\hline $\begin{array}{l}\text { Cycle Burnup } \\
\text { MWd/kgM }\end{array}$ & 10.06 & 10.90 & 11.02 & 9.87 \\
\hline $\begin{array}{l}\text { Cumulative Burnup, } \\
\text { MWd/kgM }\end{array}$ & 10.06 & 20.96 & 31.98 & 41.85 \\
\hline
\end{tabular}

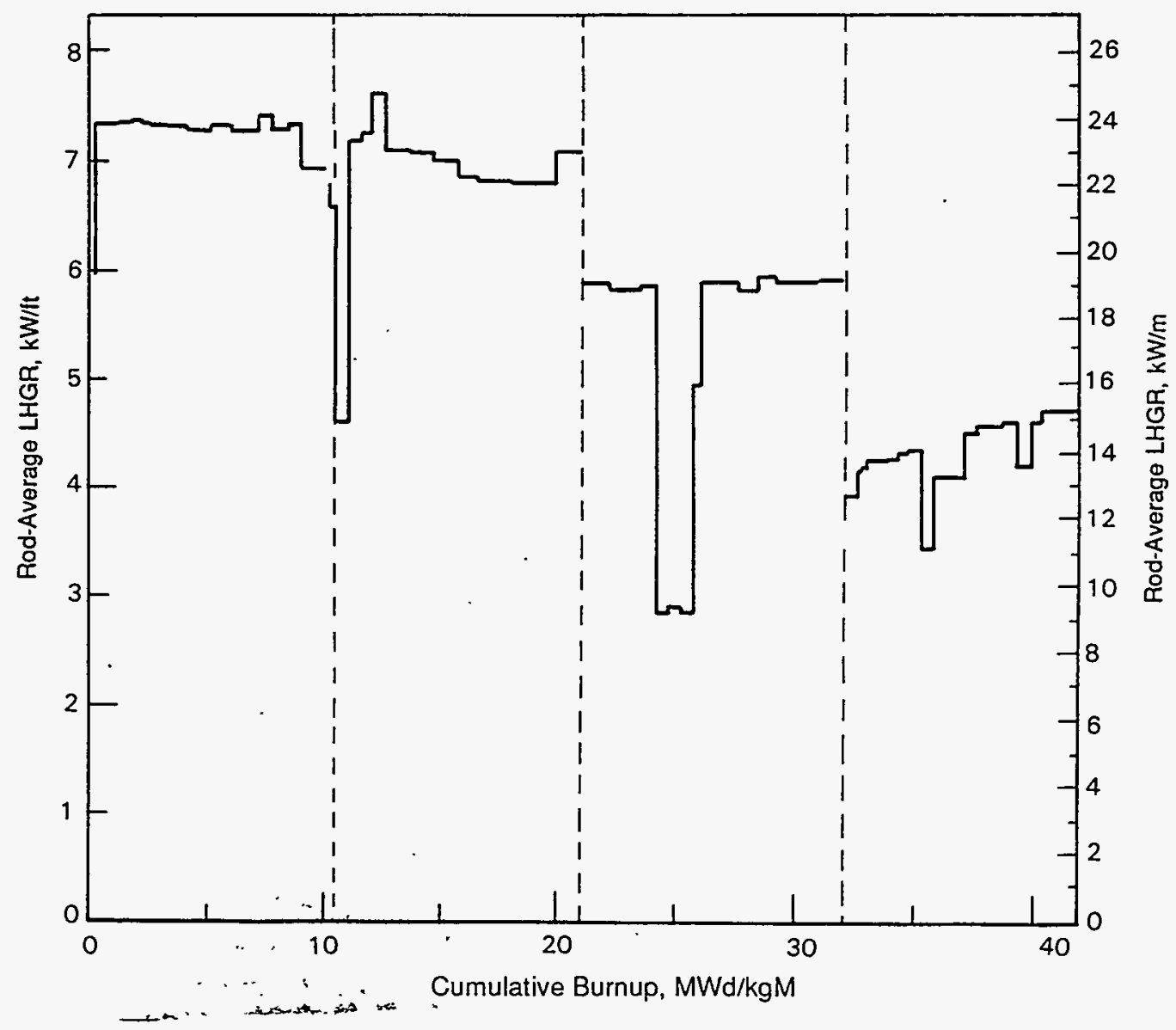

Figure 2.6. Power History for Rod MKP104 from Assembly D047 (Guenther et al. 1991a) 
Table 2.6. ATM-104 Power History, Based on Rod MKP104 (Guenther et al. 1991a)

\begin{tabular}{|c|c|c|c|c|c|c|c|}
\hline \multicolumn{2}{|c|}{ Cycle 2} & \multicolumn{2}{|c|}{ Cycle $3^{(a)}$} & \multicolumn{2}{|c|}{ Cycle 4} & \multicolumn{2}{|c|}{ Cycle 5} \\
\hline $\begin{array}{c}\text { Time } \\
\text { Interval } \\
\text { (Days) }\end{array}$ & $\begin{array}{c}\text { LHGR, } \\
\mathrm{kW} / \mathrm{m} \\
(\mathrm{kW} / \mathrm{ft})\end{array}$ & $\begin{array}{c}\text { Time } \\
\text { Interval } \\
\text { (Days) }\end{array}$ & $\begin{array}{l}\text { LHGR, } \\
\mathrm{kW} / \mathrm{m} \\
(\mathrm{kW} / \mathrm{ft})\end{array}$ & $\begin{array}{c}\text { Time } \\
\text { Interval } \\
\text { (Days) }\end{array}$ & $\begin{array}{c}\text { LHGR, } \\
\mathrm{kW} / \mathrm{m} \\
(\mathrm{kW} / \mathrm{ft})\end{array}$ & $\begin{array}{c}\text { Time } \\
\text { Interval } \\
\text { (Days) }\end{array}$ & $\begin{array}{c}\text { LHGR, } \\
\mathrm{kW} / \mathrm{m} \\
(\mathrm{kW} / \mathrm{ft})\end{array}$ \\
\hline 7.1 & $\begin{array}{l}19.5 \\
(5.94)\end{array}$ & 7.8 & $\begin{array}{l}22.2 \\
(6.77)\end{array}$ & 46.1 & $\begin{array}{l}19.4 \\
(5.90)\end{array}$ & 29.7 & $\begin{array}{l}12.9 \\
(3.93)\end{array}$ \\
\hline 30.8 & $\begin{array}{l}24.0 \\
(7.33)\end{array}$ & 14.1 & $\begin{array}{l}21.7 \\
(6.60)\end{array}$ & 24.0 & $\begin{array}{l}19.2 \\
(5.85)\end{array}$ & 5.9 & $\begin{array}{l}13.7 \\
(4.18)\end{array}$ \\
\hline 16.4 & $\begin{array}{l}24.1 \\
(7.35)\end{array}$ & 19.4 & $\begin{array}{l}15.2 \\
(4.63)\end{array}$ & 22.6 & $\begin{array}{l}19.2 \\
(5.85)\end{array}$ & 7.1 & $\begin{array}{l}13.8 \\
(4.22)\end{array}$ \\
\hline 11.4 & $\begin{array}{l}24.1 \\
(7.36)\end{array}$ & 16.9 & $\begin{array}{l}23.6 \\
(7.20)\end{array}$ & 25.6 & $\begin{array}{l}19.2 \\
(5.86)\end{array}$ & 48.2 & $\begin{array}{l}14.0 \\
(4.26)\end{array}$ \\
\hline 12.5 & $\begin{array}{l}24.1 \\
(7.35)\end{array}$ & 16.4 & $\begin{array}{l}23.8 \\
(7.25)\end{array}$ & 30.5 & $\begin{array}{c}9.4 \\
(2.87)\end{array}$ & 16.8 & $\begin{array}{l}14.0 \\
(4.27)\end{array}$ \\
\hline 23.4 & $\begin{array}{l}24.1 \\
(7.34)\end{array}$ & 15.4 & $\begin{array}{l}25.1 \\
(7.65)\end{array}$ & 41.1 & $\begin{array}{c}9.6 \\
(2.92)\end{array}$ & 29.4 & $\begin{array}{l}14.2 \\
(4.34)\end{array}$ \\
\hline 22.8 & $\begin{array}{l}24.0 \\
(7.31)\end{array}$ & 39.4 & $\begin{array}{l}23.3 \\
(7.11)\end{array}$ & 50.2 & $\begin{array}{c}9.4 \\
(2.88)\end{array}$ & 24.7 & $\begin{array}{l}14.3 \\
(4.37)\end{array}$ \\
\hline 23.2 & $\begin{array}{l}23.9 \\
(7.27)\end{array}$ & 31.4 & $\begin{array}{l}23.3 \\
(7.10)\end{array}$ & 11.1 & $\begin{array}{l}16.3 \\
(4.98)\end{array}$ & 30.0 & $\begin{array}{l}11.3 \\
(3.45)\end{array}$ \\
\hline 8.1 & $\begin{array}{l}23.8 \\
(7.26)\end{array}$ & 31.9 & $\begin{array}{l}23.0 \\
(7.01)\end{array}$ & 10.0 & $\begin{array}{l}19.4 \\
(5.90)\end{array}$ & 55.3 & $\begin{array}{l}13.5 \\
(4.12)\end{array}$ \\
\hline 31.4 & $\begin{array}{l}24.0 \\
(7.32)\end{array}$ & 32.0 & $\begin{array}{l}22.6 \\
(6.88)\end{array}$ & 45.4 & $\begin{array}{l}19.4 \\
(5.92)\end{array}$ & 27.1 & $\begin{array}{l}14.8 \\
(4.52)\end{array}$ \\
\hline 34.3 & $\begin{array}{l}23.8 \\
(7.26)\end{array}$ & 44.3 & $\begin{array}{l}22.5 \\
(6.85)\end{array}$ & 29.4 & $\begin{array}{l}19.1 \\
(5.82)\end{array}$ & 45.7 & $\begin{array}{l}15.1 \\
(4.59)\end{array}$ \\
\hline 16.5 & $\begin{array}{l}24.2 \\
(7.39)\end{array}$ & 59.1 & $\begin{array}{l}22.4 \\
(6.84)\end{array}$ & 28.1 & $\begin{array}{l}19.5 \\
(5.95)\end{array}$ & 23.5 & $\begin{array}{l}15.2 \\
(4.62)\end{array}$ \\
\hline 19.2 & $\begin{array}{l}23.8 \\
(7.26)\end{array}$ & 28.9 & $\begin{array}{l}23.3 \\
(7.11)\end{array}$ & 65.4 & $\begin{array}{l}19.4 \\
(5.91)\end{array}$ & 30.2 & $\begin{array}{l}13.8 \\
(4.21)\end{array}$ \\
\hline 12.8 & $\begin{array}{l}24.0 \\
(7.31)\end{array}$ & & & 35.7 & $\begin{array}{l}19.5 \\
(5.93)\end{array}$ & 20.8 & $\begin{array}{l}15.2 \\
(4.62)\end{array}$ \\
\hline 34.3 & $\begin{array}{l}22.7 \\
(6.93)\end{array}$ & & & & & 66.6 & $\begin{array}{l}15.5 \\
(4.73)\end{array}$ \\
\hline 1.8 & $\begin{array}{l}22.8 \\
(6.94)\end{array}$ & & & & & & \\
\hline
\end{tabular}

(a) Reactor was shut down for 25 days starting with day 270 of Cycle 3. 


\subsubsection{Assembly, Fuel Rod, and Pellet Description}

Like ATM-103 and ATM-104, the fuel rods in ATM-106 were from a standard C-E $14 \times 14$ fuel assembly (BT03) comparable to that shown in Figure 2.1. The rod design was the same as for the ATM-103 and ATM-104 fuel rods, but the fuel pellets are approximately one-and-a-half-times longer than the ATM-103 or ATM-104 fuel pellets, and the void volumes of the two dished ends in the pellets are $-38 \%$ smaller. A drawing of the ATM-106 fuel pellet is shown in Figure 2.7, and the fuel pellet certification data for Assembly BT03 are shown in Table 2.7.

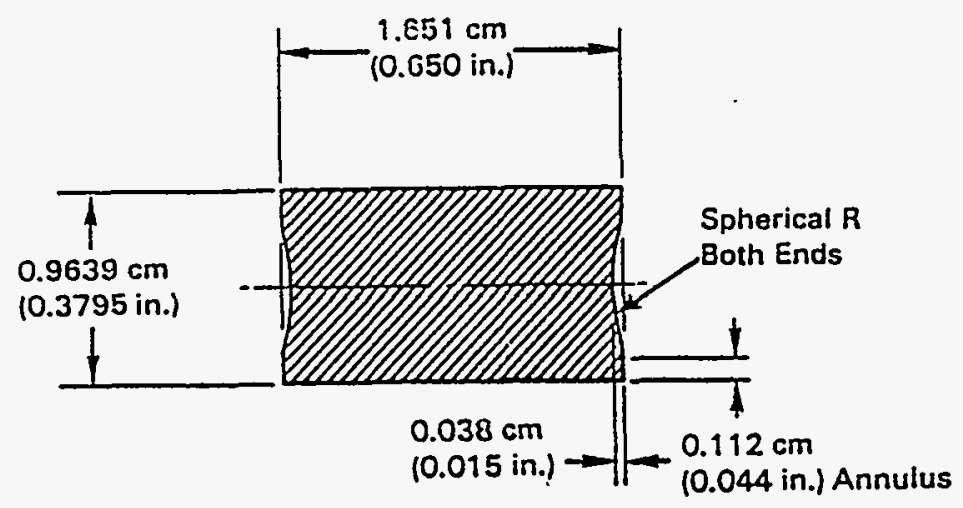

Fuel Pellet Schematic

Figure 2.7. Fuel Pellet Design for ATM-106 (Guenther et al. 1988b)

Table 2.7. ATM-106 Fuel Pellet Certification Data (Guenther et al. 1988b)

Chemical Attribute

Total uranium wt\%

Carbon, ppm

Nitrogen, ppm

Fluorine, ppm

Total halides, ppm

Iron, ppm

Silver, ppm

Calcium, ppm

Aluminum, ppm

Silicon, ppm

$\mathrm{O}: \mathrm{U}$ ratio

Mass spec. analysis

Density

Grain size
Fuel Lot B-25-BB Analysis Results

\begin{tabular}{lcccc}
\hline 88.158 & 88.136 & 88.136 & 88.142 & 88.142 \\
17 & 23 & 33 & 9 & 15 \\
39 & 41 & 47 & 45 & 48 \\
$<10$ & $<10$ & $<10$ & $<10$ & $<10$ \\
$<20$ & $<20$ & $<20$ & $<20$ & $<20$ \\
$<45$ & $<45$ & $<45$ & $<45$ & $<45$ \\
$<1$ & $<1$ & $<1$ & $<1$ & $<1$ \\
$<115$ & $<115$ & $<115$ & $<117$ & $<132$ \\
2.00 & 2.00 & \multicolumn{4}{c}{2.00} & 2.00 &. \\
& \multicolumn{5}{c}{$2.453 \%$} & $235 \mathrm{U}$ \\
& \multicolumn{5}{c}{$10.05-10.30 \mathrm{~g} / \mathrm{cm}^{3}$} \\
& $\geq 5 \mu \mathrm{m}$
\end{tabular}


All ATM-106 fuel rods are clad with Zircaloy-4 tubing fabricated by Sandvik Special Metals, Lot Nos. 54028 and 54027. Cladding certification data are listed in Table 2.8. Rods NBD095 and NBD131 were irradiated in positions G9 and M4, respectively, as shown in Figure 2.8.

\subsubsection{Irradiation History}

The rods constituting ATM-106 were irradiated in Assembly BT03 in Cycles 1, 2, 3, and 4 of operation of CC-1 between October 7, 1974, and October 18, 1980. The ATM-106 fuel rods were also in the reactor during a five-month period of reduced power during Cycle 4.

To achieve the desired fuel burnup, assembly BT03 was placed in the core's center during Cycles 3 and 4. As a result, LHGRs in Rod NBD107 ranged from a high of about $24 \mathrm{~kW} / \mathrm{m}(7.3 \mathrm{~kW} / \mathrm{ft})$ at the beginning of Cycle 1 to a low of about $16 \mathrm{~kW} / \mathrm{m}(4.8 \mathrm{~kW} / \mathrm{ft})$ at the end of Cycle 4 . The power history specific to Rod NBD107 in Assembly BT03 is approximated in Figure 2.9 and shown in Table 2.9. Power histories for other ATM-106 rods can be determined, as explained above for ATM-103 and ATM-104.

\subsection{ATM-108 Design and Power History}

ATM-108 consists of the ten fuel rods with both urania $\left(\mathrm{UO}_{2}\right)$ and gadolinia $\left(\mathrm{Gd}_{2} \mathrm{O}_{3}\right)$ in the CZ346 and CZ348 fuel bundles, which also contained the fuel rods designated as ATM-105. The fuel bundles were fabricated by GE and irradiated in the Cooper BWR (Guenther et al. 1991b). The bundles were fabricated in 1972 and irradiated for five cycles from July 1974 to May 1982, at which time they were discharged. The two fuel bundles were stored wet at the reactor site and subsequently sent to the GE Morris Facility for use in a dry storage test described by McKinnon et al. (1986). The information on the fuel bundle design was reported by Guenther et al. (1991b) in which the completed characterization of Rods ADD2966 and ADD2974 without gadolinia from the same fuel bundle as ADN0206 is described. Information is provided in Subsection 2.4.1 and 2.4.2 on the bundle and rod design and power history during irradiation.

\subsubsection{Fuel Bundle and Rod Description}

Fuel bundles CZ346 and CZ348 are of the GE $7 \times 7$ design, as shown in Figure 2.10. Eight tie rods, one segmented rod (spacer capture rod), and 40 standard rods are three fuel rod designs clad with Zircaloy-2 which are used in the fuel bundles. The location of the tie rods, segmented rod, and standard rods are shown in Figure 2.11. There are standard rods with and without gadolinia. The tie rods have threaded-end plugs that thread into the lower-tie-plate casting and extend through the upper-tieplate casting. The upper ends of the tie rods are secured with lock nuts to hold the bundle together. The central fuel rod in each fuel bundle is segmented, consisting of eight individual tubes of fuel pellets separated by Zircaloy-2 connectors; this rod is one of the ATM-108 rods. Available bundle and fuel rod design parameters are shown in Table 2.10. Additional details on the bundle design are provided in Guenther et al. (1991b). 
Table 2.8. ATM-106 Fuel Rod Cladding Certification Data (Guenther et al. 1988b)

ROD LOT: NBC

Fuel Assembly: BT03 CLADDING LOT: 54028

Tensile Properties

Room UTS, psi

$0.2 \%$ YS, psi

Elong. 2 in., \%

$750^{\circ} \mathrm{F}$ UTS, psi

$0.2 \% \mathrm{YS}, \mathrm{psi}$

Elong. 2 in., \%

$\begin{array}{cc}98500 & 97900 \\ 74300 & 73900 \\ 23.2 & 24.4 \\ 52200 & 50000 \\ 36600 & 32600 \\ \end{array}$

$29.8 \quad 34.4$
ROD LOT: NBC/NBD CLADDING LOT: 54027

$\begin{array}{cc}89000 & 97300 \\ 64500 & 69700 \\ 27.9 & 24.8 \\ 48200 & 52700 \\ 32000 & 36500 \\ 31.8 & 29.2\end{array}$

Burst Test (closed end with mandrel at room temperature)

Pressure, psi

Circ. elong., \% 16000

20.

20.1

34.7

15100

45.3

15900

22

Hydride Orientation

OD

$\begin{array}{ll}0.06 & 0.07 \\ 0.04 & 0.06 \\ 0.02 & 0.02\end{array}$

ID

0.05

0.02

0.03

15.3

13.8

13.5

46

55

$\begin{array}{lll}12.5 & 13.5 & 13.8 \\ & 46 & 55\end{array}$

Chemical Analysis, ppm

\section{Hydrogen}

Nitrogen

Oxygen

Carbon

Grain Size

Long. ASTM

Trans. ASTM

Recrystallization Data

$\begin{array}{rr}12 & 13 \\ 38 & 45 \\ 1260 & 1230 \\ 151 & 160\end{array}$

11.5

11.0

12.0

12.0

$1100^{\circ} \mathrm{F}, 45 \mathrm{~min}$

Surface Roughness

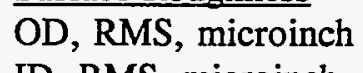

ID, RMS, microinch
12

12
10

20
11.5

12.0

$1100^{\circ} \mathrm{F}, 45 \mathrm{~min}$

11.5

12.0

14

16
13.8

57 


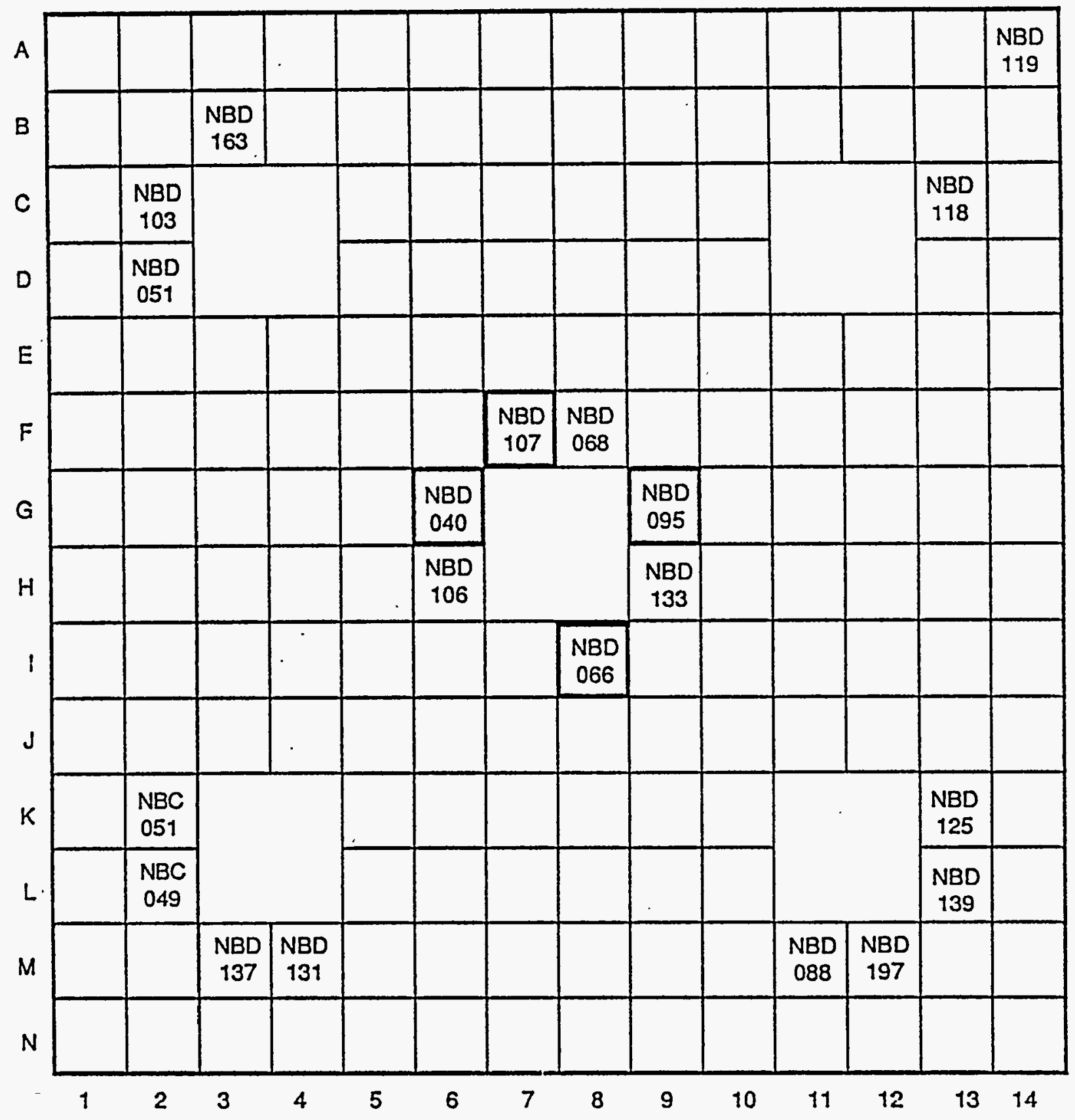

Figure 2.8. Locations of Twenty Rods in Assembly BT03 (characterized rods denoted in highlighted boxes) (Guenther et al. 1988b) 


\begin{tabular}{|l|c|c|c|c|}
\hline Cycle No. & 1 & 2 & 3 & 4 \\
\hline Start,'End of Cycle & $10-7-74 / 12-31-76$ & $\begin{array}{c}3-22-77 / \\
1-22-78\end{array}$ & $\begin{array}{c}4-3-78 / \\
4-20-79\end{array}$ & $\begin{array}{c}7-10-79 / \\
10-18-80\end{array}$ \\
\hline Cycle Duration & $\sim 24$ months & $\sim 10$ months & $\begin{array}{c}-12.5 \\
\text { months }\end{array}$ & $\sim 15$ months \\
\hline $\begin{array}{l}\text { Cycle Burnup } \\
\text { MWd/kgM }\end{array}$ & 19.67 & 7.70 & 6.72 & 8.23 \\
\hline $\begin{array}{l}\text { Cumulative Burnup } \\
\text { MWd/kgM }\end{array}$ & 19.67 & 27.37 & 34.09 & 42.32 \\
\hline
\end{tabular}

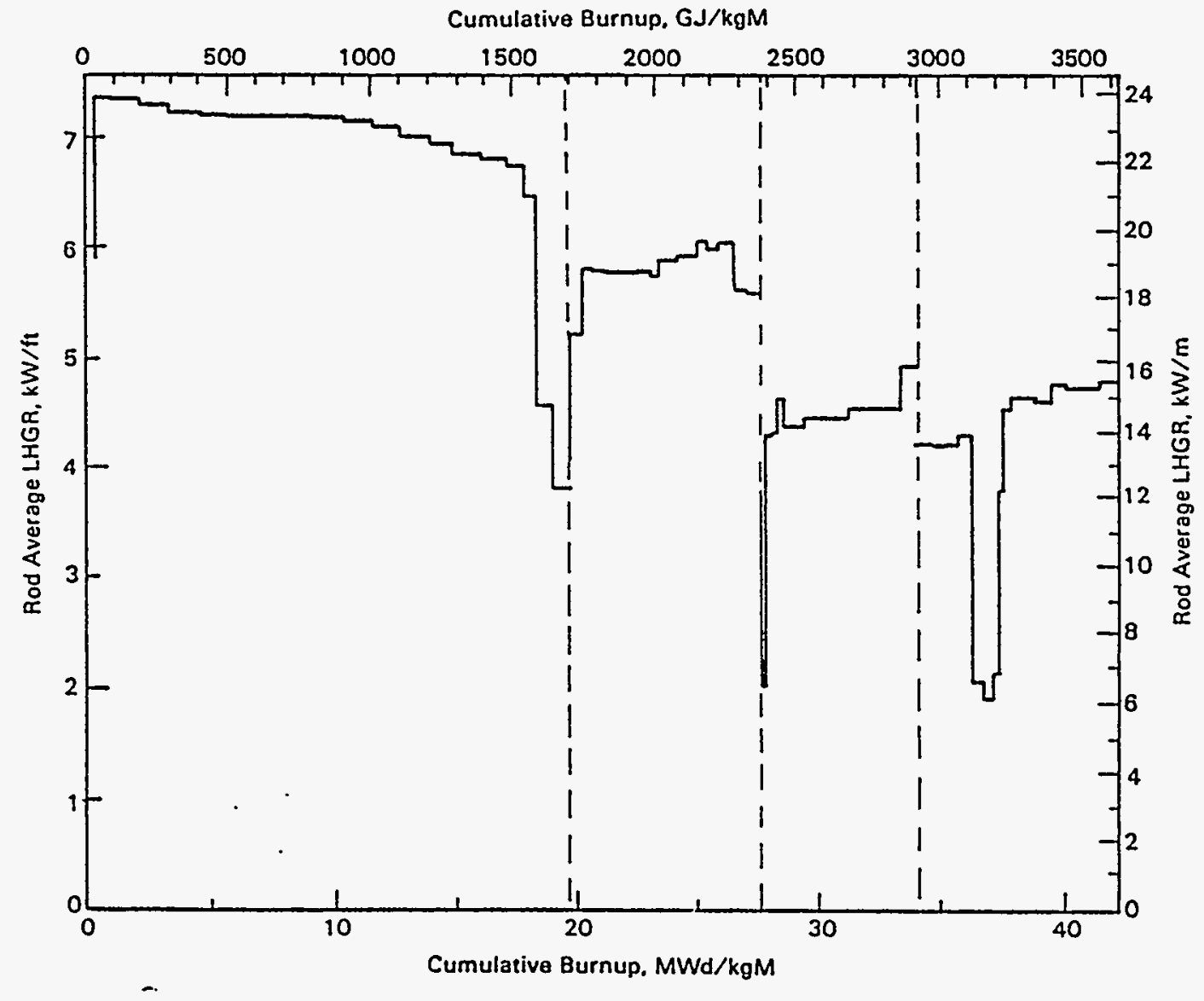

Figure 2.9. Approximate Power History for Rod NBD 107 from Assembly BT03 (Guenther et al. 1988b) 
Table 2.9. Detailed Power History for Rod NBD107 (Guenther et al. 1988b)

\begin{tabular}{|c|c|c|c|c|c|c|c|}
\hline \multicolumn{2}{|c|}{ Cycle 1} & \multicolumn{2}{|c|}{ Cycle 2} & \multicolumn{2}{|c|}{ Cycle $3^{(2)}$} & \multicolumn{2}{|c|}{ Cycle 4} \\
\hline $\begin{array}{c}\text { Time } \\
\text { Interval, } \\
\text { (Days) }\end{array}$ & $\begin{array}{l}\text { LHGR, } \\
\mathrm{kW} / \mathrm{m} \\
(\mathrm{kW} / \mathrm{ft})\end{array}$ & $\begin{array}{c}\text { Time } \\
\text { Interval,( } \\
\text { Days) }\end{array}$ & $\begin{array}{c}\text { LHGR, } \\
\mathrm{kW} / \mathrm{m} \\
(\mathrm{kW} / \mathrm{ft})\end{array}$ & $\begin{array}{c}\text { Time } \\
\text { Interval, } \\
\text { (Days) }\end{array}$ & $\begin{array}{l}\mathrm{LHGR}, \\
\mathrm{kW} / \mathrm{m} \\
(\mathrm{kw} / \mathrm{ft})\end{array}$ & $\begin{array}{c}\text { Time } \\
\text { Interval, } \\
\text { (Days) }\end{array}$ & $\begin{array}{l}\text { LHGR, } \\
\mathrm{kW} / \mathrm{m} \\
(\mathrm{kw} / \mathrm{ft})\end{array}$ \\
\hline 24.2 & $\begin{array}{l}19.2 \\
(5.84)\end{array}$ & 7.2 & $\begin{array}{l}13.3 \\
(4.06)\end{array}$ & 10.9 & $\begin{array}{l}12.6 \\
(3.84)\end{array}$ & 45.0 & $\begin{array}{l}13.8 \\
(4.21)\end{array}$ \\
\hline 19.6 & $\begin{array}{l}24.1 \\
(7.36)\end{array}$ & 31.0 & $\begin{array}{l}17.1 \\
(5.20)\end{array}$ & 14.1 & $\begin{array}{l}12.4 \\
(3.78)\end{array}$ & 24.1 & $\begin{array}{l}13.8 \\
(4.20)\end{array}$ \\
\hline 39.7 & $\begin{array}{l}24.1 \\
(7.34)\end{array}$ & 16.4 & $\begin{array}{l}19.0 \\
(5.80)\end{array}$ & 25.3 & $\begin{array}{c}6.7 \\
(2.03)\end{array}$ & 22.4 & $\begin{array}{l}13.9 \\
(4.23)\end{array}$ \\
\hline 39.7 & $\begin{array}{l}23.9 \\
(7.27)\end{array}$ & 11.4 & $\begin{array}{l}18.9 \\
(5.77)\end{array}$ & 12.2 & $\begin{array}{l}14.0 \\
(4.27)\end{array}$ & 25.2 & $\begin{array}{l}14.1 \\
(4.29)\end{array}$ \\
\hline 39.4 & $\begin{array}{l}23.7 \\
(7.22)\end{array}$ & 12.6 & $\begin{array}{l}18.9 \\
(5.76)\end{array}$ & 16.3 & $\begin{array}{l}14.2 \\
(4.33)\end{array}$ & 31.0 & $\begin{array}{c}6.7 \\
(2.05)\end{array}$ \\
\hline 39.3 & $\begin{array}{l}23.6 \\
(7.18)\end{array}$ & 23.2 & $\begin{array}{l}18.9 \\
(5.76)\end{array}$ & 15.1 & $\begin{array}{l}15.2 \\
(4.63)\end{array}$ & 44.8 & $\begin{array}{c}6.3 \\
(1.91)\end{array}$ \\
\hline 39.1 & $\begin{array}{l}23.5 \\
(7.17)\end{array}$ & 22.7 & $\begin{array}{l}18.9 \\
(5.76)\end{array}$ & 38.1 & $\begin{array}{l}14.3 \\
(4.37)\end{array}$ & 48.1 & $\begin{array}{l}7.0 \\
(2.13)\end{array}$ \\
\hline 38.9 & $\begin{array}{l}23.6 \\
(7.18)\end{array}$ & 23.0 & $\begin{array}{l}18.9 \\
(5.76)\end{array}$ & 30.9 & $\begin{array}{l}14.6 \\
(4.44)\end{array}$ & 10.9 & $\begin{array}{l}12.4 \\
(3.78)\end{array}$ \\
\hline 39.0 & $\begin{array}{l}23.6 \\
(7.18)\end{array}$ & 8.2 & $\begin{array}{l}18.8 \\
(5.74)\end{array}$ & 31.4 & $\begin{array}{l}14.6 \\
(4.45)\end{array}$ & 10.6 & $\begin{array}{l}14.9 \\
(4.54)\end{array}$ \\
\hline 39.1 & $\begin{array}{l}23.5 \\
(7.16)\end{array}$ & 31.0 & $\begin{array}{l}19.3 \\
(5.88)\end{array}$ & 31.5 & $\begin{array}{l}14.6 \\
(4.44)\end{array}$ & 45.3 & $\begin{array}{l}15.2 \\
(4.63)\end{array}$ \\
\hline 39.1 & $\begin{array}{l}23.3 \\
(7.11)\end{array}$ & 33.8 & $\begin{array}{l}19.4 \\
(5.90)\end{array}$ & 43.2 & $\begin{array}{l}14.8 \\
(4.52)\end{array}$ & 28.7 & $\begin{array}{l}15.1 \\
(4.59)\end{array}$ \\
\hline 39.4 & $\begin{array}{l}23.1 \\
(7.05)\end{array}$ & 16.5 & $\begin{array}{l}19.8 \\
(6.03)\end{array}$ & 60.0 & $\begin{array}{l}14.9 \\
(4.53)\end{array}$ & 27.9 & $\begin{array}{l}15.6 \\
(4.75)\end{array}$ \\
\hline 39.3 & $\begin{array}{l}22.9 \\
(6.97)\end{array}$ & 19.1 & $\begin{array}{l}19.6 \\
(5.97)\end{array}$ & 28.0 & $\begin{array}{l}16.1 \\
(4.92)\end{array}$ & 65.9 & $\begin{array}{l}15.5 \\
(4.71)\end{array}$ \\
\hline 39.3 & $\begin{array}{l}22.6 \\
(6.90)\end{array}$ & 12.8 & $\begin{array}{l}19.8 \\
(6.02)\end{array}$ & & & 36.1 & $\begin{array}{l}15.7 \\
(4.79)\end{array}$ \\
\hline 39.3 & $\begin{array}{l}22.4 \\
(6.82)\end{array}$ & 35.2 & $\begin{array}{l}18.4 \\
(5.62)\end{array}$ & & & & \\
\hline 39.3 & $\begin{array}{l}22.2 \\
(6.76)\end{array}$ & 1.9 & $\begin{array}{l}18.3 \\
(5.57)\end{array}$ & & & & \\
\hline 19.6 & $\begin{array}{l}22.0 \\
(6.72)\end{array}$ & & & & & & \\
\hline 20.4 & $\begin{array}{l}21.1 \\
(6.44)\end{array}$ & & & & & & \\
\hline 30.8 & $\begin{array}{l}14.9 \\
(4.54)\end{array}$ & & & & & & \\
\hline 32.8 & $\begin{array}{l}12.3 \\
\mathbf{( 3 . 7 6 )}\end{array}$ & & & & & & \\
\hline
\end{tabular}

(a) Reactor was shut down for 25 days starting with day 270 of Cycle 3. 
$0 \tau \cdot \tau$

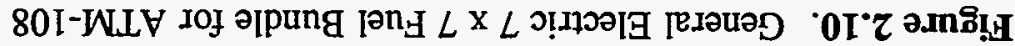
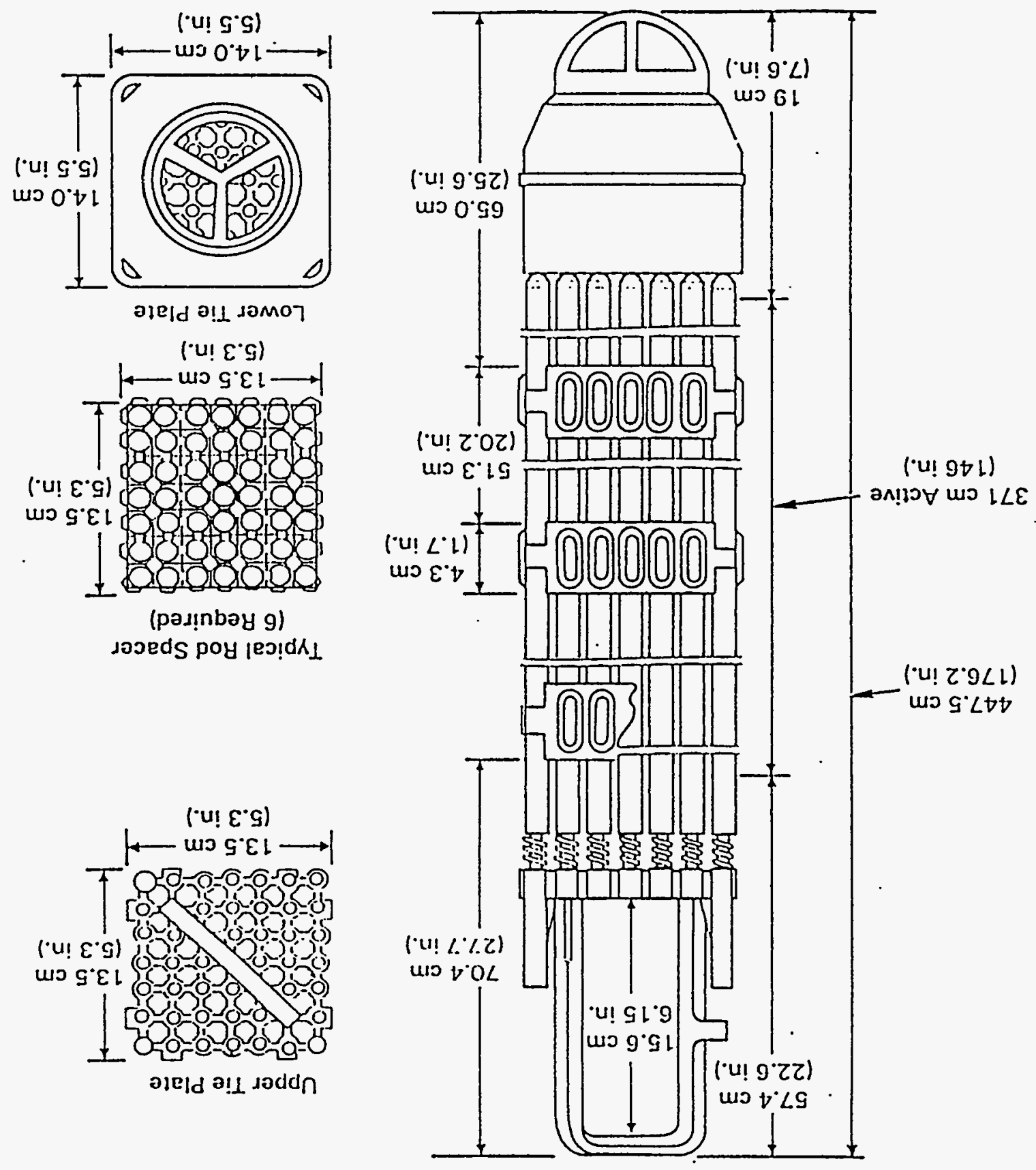

('U! E*g)

wo $g^{\circ} \varepsilon \downarrow$

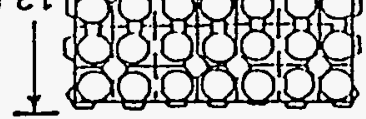

(раנ!nbay 9) Jooeds poy leo!d $\Lambda_{\perp}$

oleld a! $\perp$ Jadd 


Wide-Wide Corner
\begin{tabular}{r|r|r|r|r|r|r|}
\hline & & $T$ & & $T$ & & 3 \\
\hline 3 & 3 & 3 & 2 & 2 & 2 & 3 \\
\hline$T$ & 7 & 1 & 1 & 1 & 1 & 2 \\
\hline 3 & 1 & 1 & 1 & 1 & 5 & 1 \\
\hline 2 & 1 & 1 & 5 & 1 & 1 & 1 \\
\hline$T$ & & & & & & $T$ \\
2 & 1 & 1 & 1 & 1 & 1 & 1 \\
\hline 2 & 1 & 5 & 1 & 1 & 6 & 2 \\
\hline 3 & 2 & 1 & 1 & 1 & 2 & 2 \\
\hline
\end{tabular}

Fuel Bundle Map

\begin{tabular}{|c|c|c|c|}
\hline Rod Type & $\begin{array}{c}\text { Enrichmont. } \\
W t \%, U-235\end{array}$ & $\begin{array}{c}W l \% \\
\mathrm{Gd}_{2} \mathrm{O}_{3}\end{array}$ & $\begin{array}{c}\text { Number } \\
\text { of Rods }\end{array}$ \\
\hline 1 & 2.93 & 0 & 26 \\
\hline 2 & 1.94 & 0 & 11 \\
\hline 3 & 1.69 & 0 & 6 \\
\hline 4 & 1.33 & 0 & 1 \\
\hline 5 & 2.93 & 3.0 & 3 \\
\hline 6 & 2.93 & 4.0 & 1 \\
\hline 7 & 1.94 & 4.0 & 1 \\
\hline
\end{tabular}

Legend

S - Spacer Capture Rod

$T$ - Tie Rods

Figure 2.11. Location of Different Types of Fuel Rods in Bundles CZ346 and CZ348 (Guenther et al. 1988b) 
Table 2.10. ATM-105 Fuel Bundle and Rod Design Parameters

(Guenther et al. 1991b)

\begin{tabular}{llll}
\multicolumn{1}{c}{ Design Parameter } & & \multicolumn{2}{c}{ Description } \\
\cline { 1 - 1 } Fuel rod array & & $7 \times 7$ & \\
Overall bundle length & & $447.5 \mathrm{~cm}$ & $(176.2 \mathrm{in})$. \\
Nominal active fuel length & & $371 \mathrm{~cm}$ & $(146 \mathrm{in})$. \\
Fuel rod pitch & & $1.87 \mathrm{~cm}$ & $(0.738 \mathrm{in})$. \\
Outside rod diameter & & $1.43 \mathrm{~cm}$ & $(0.563 \mathrm{in})$. \\
Cladding thickness & & $0.094 \mathrm{~cm}$ & $(0.037 \mathrm{in})$. \\
Cladding material & & $\mathrm{Zircaloy}^{\prime}-2$ & \\
Pellet outside diameter & & $1.21 \mathrm{~cm}$ & $(0.477 \mathrm{in})$. \\
Fuel pellet material & & $\mathrm{UO}_{2}^{(\mathrm{a})}$ & \\
Pellet immersion density & & $10.32 \mathrm{~g} / \mathrm{cm}^{3}$ & $\left(0.37 \mathrm{lb} / \mathrm{in}^{3}\right)$ \\
Fission gas plenum length & $35.6 \mathrm{~cm}$ & $(14 \mathrm{in})$. \\
Helium fill gas pressure & & $1.0 \mathrm{~atm}$ & $(14.7 \mathrm{psia})$
\end{tabular}

(a) Five fuel rods that contain $\mathrm{UO}_{2}$ and $\mathrm{Gd}_{2} \mathrm{O}_{3}$ have been redesignated as ATM-108; they will be removed from the bundles and characterized.

Considering the fuel enrichment and amount of gadolinia, there are seven fuel rod types in these GE bundles (Figure 2.11). Five of the 49 rods in each bundle had either 3 or $4 \mathrm{wt} \%$ gadolinia to act as a burnable poison and comprised the ATM-108 test material. Only the Type 5 fuel rods with 3 wt\% gadolinia have burnable poison along the entire fuel column length, as shown in Figure 2.12. Rod ADN0206 was selected for characterization because it was near other characterized rods and had gadolinia along the entire fuel column. Rod ADN0206 was irradiated in position F3 of bundle CZ346, as shown in Figure 2.13.

Only limited data are available for the material properties and design specifications of the fuel and Zircaloy-2 cladding of ATM-105 and ATM-108 fuel rods; most of the information was considered proprietary. As reported in Guenther et al. (1991b), the pellets are flat-ended with chamfered edges and are about 1.3-cm-long based on gamma scan data. Compositions were assumed for the fuel and cladding of the ATM-105 fuel rods without gadolinia and are shown in Tables 2.11 and 2.12. The reader is left to estimate any changes necessary to compensate for the gadolinia content or differences in fuel enrichment. The assumed values are based on nominal values for low-enriched fuel or for typical Zircaloy-2 cladding. 


\section{ATM-108 Fuel Rod Types}

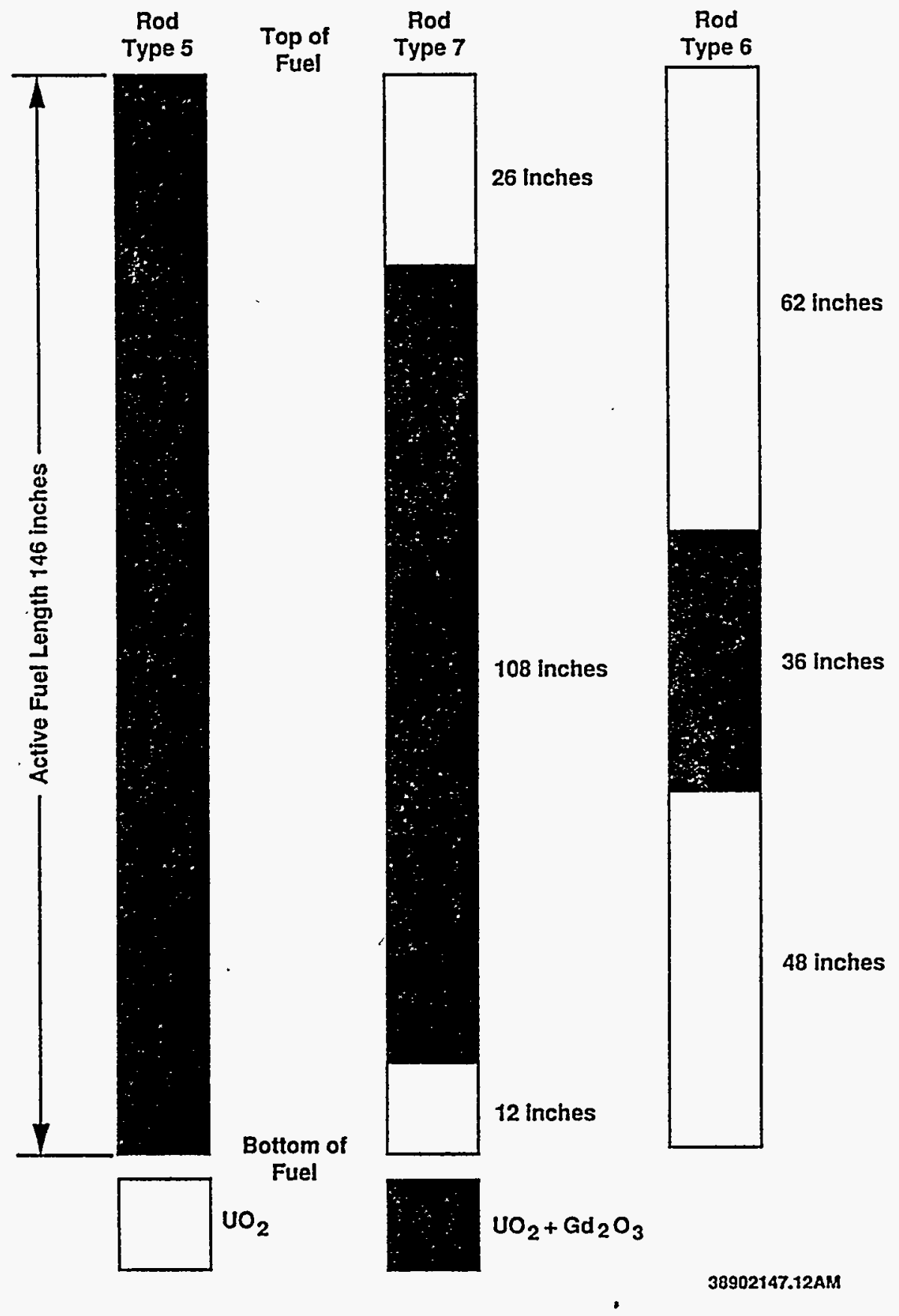

Figure 2.12. Gadolinia Loading in Type 5, Type 6, and Type 7 Rods in ATM-108 


\begin{tabular}{|c|c|c|c|c|c|c|c|}
\hline & & N & 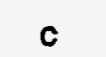 & 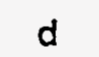 & e & 1 & $\mathbf{y}$ \\
\hline & & & & $E$ & $\bar{B}$ & ADE & \\
\hline & & 16 & 47 & 70 & 321 & $1 \times 8$ & 653 \\
\hline & & סחA & $\bar{D}$ & חח & $\Delta D^{\prime}$ & $\Delta \cap B$ & $D E$ \\
\hline & 0621 & 0262 & 965 & 963 & $967^{\prime}$ & 2991 & 553 \\
\hline & $c$ & $\overline{D D}$ & ADD & $\overline{D D}$ & $\overrightarrow{A D D}$ & $A D N$ & ADA \\
\hline & 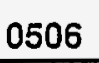 & 2966 & 2974 & $37^{\prime}$ & $950^{\prime}$ & 0206 & 724 \\
\hline & & & & & & & DD \\
\hline & 1507 & 2964 & 2945 & & 66 & 4319 & 2931 \\
\hline & & $A D D$ & & $D$ & D & D & $\overline{A D A}$ \\
\hline & 0309 & $432 \sigma$ & $4352^{\prime}$ & 4361 & 4326 & 4373 & 0714 \\
\hline & & $96 n$ & $\triangle A D N$ & $7 \pi$ & $\pi$ & ADS & $A D E$ \\
\hline & 1527 & पर & 1313 & 45 & 4363 & 0134 & 1569 \\
\hline & $\overline{A D G}$ & $A D E$ & 10 & $\overline{A D}$ & ADA & ADE & $\overline{\mathrm{ADE}}$ \\
\hline & 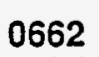 & 1540 & tis & & 177 & 54 & 1537 \\
\hline
\end{tabular}

\section{Bundle CZ346}

Figure 2.13. Loading Diagram for Bundle CZ346 (ATM-108 rods are denoted in highlighted boxes)

\subsubsection{Irradiation History}

Fuel Bundles CZ346 and CZ348 were irradiated in the Cooper BWR during Cycles 1, 2, 3, 6, and 7. Cycle 1 began July 4, 1974, and Cycle 7 ended May 21, 1982. Fuel Bundles CZ346 and CZ348 were not in the reactor during Cycles 4 and 5. The power history for the ATM-105 fuel was based on the history associated with Bundle CZ346. The average burnup for Bundle CZ346 at the end of each cycle was supplied by GE and is shown in Table 2.13. No specific power history for Rod ADN0206 has been provided or determined. Because the gadolinia eventually burns out, the power in the rods would typically start at a low value and increase with time depending on the rate of burnout, the gadolinia content, and the overall power in the assembly; the power history calculations have not been determined. 
Table 2.11. Fuel Composition Assumed for ATM-105 Fuel Rods (from Guenther et al. 1991b)

\begin{tabular}{lc}
\multicolumn{1}{c}{ Parameter } & Value $^{(\mathrm{a})}$ \\
Enrichment, wt\% & $2.939^{(\mathrm{b})}$ \\
${ }^{234} \mathrm{U}, \mathrm{ppm}$ & $238.2^{(\mathrm{c})}$ \\
Total uranium, wt\% & 88.147 \\
Oxygen, wt\% & 11.853 \\
Carbon, ppm & 18 \\
Nitrogen, ppm & 23 \\
Fluorine, ppm & 5 \\
Chlorine, ppm & 5 \\
Chromium, ppm & $0^{(\mathrm{d})}$ \\
Iron, ppm & 45 \\
Silver, ppm & 1 \\
Calcium, ppm & 32 \\
Aluminum, ppm & 32 \\
Silicon, ppm & 32 \\
Nickel, ppm & 25
\end{tabular}

(a) Based on nominal values for low-enriched fuel used in other ATMs; measured data not available.

(b) Provided by GE.

(c) Interpolated value based on ${ }^{235} \mathrm{U}$ fuel enrichments.

(d) Although assumed to be absent for the ORIGEN2 calculations, chromium and a few other elements were detected by ATM as minor impurities. 
Table 2.12. Cladding Composition Assumed for ATM-105 Fuel Rods (from Guenther et al. 1991b)

\begin{tabular}{lcc}
\multicolumn{1}{c}{ Parameter } & & Value \\
\cline { 3 - 3 } Zirconium, wt\% & & 98.05 \\
Tin, wt\% & & 1.5 \\
Iron, wt\% & & 0.13 \\
Chromium, wt\% & & 0.11 \\
Nickel, ppm & & 500 \\
Aluminum, ppm & & 40 \\
Hafnium, ppm & & 55 \\
Silicon, ppm & & 80 \\
Oxygen, ppm & & 1200 \\
Carbon, ppm & & 175 \\
Nitrogen, ppm & 35 \\
Hydrogen, ppm & 12
\end{tabular}

Table 2.13. Burnup of Bundle CZ346 (Guenther et al. 1991b)

\begin{tabular}{|c|c|c|c|}
\hline Cycle No. & Startup & Shutdown & $\begin{array}{c}\text { Cumulative } \\
\text { Bundle-Average } \\
\text { Burnup, MWd/kgM }\end{array}$ \\
\hline 1 & $07 / 04 / 74$ & $09 / 17 / 76$ & 13.90 \\
\hline 2 & $11 / 16 / 76$ & $09 / 17 / 77$ & 19.14 \\
\hline 3 & $10 / 18 / 77$ & $03 / 31 / 78$ & 21.92 \\
\hline 6 & $06 / 08 / 80$ & $04 / 20 / 81$ & 25.20 \\
\hline 7 & $08 / 08 / 81$ & $05 / 21 / 82$ & 28.05 \\
\hline
\end{tabular}




\subsection{Gamma Scans and Rod Sectioning}

Each fuel rod was gamma scanned to obtain information on the general trend of burnup and to provide a basis for selecting fuel and cladding samples. A brief summary of this process is provided below.

\subsection{Gamma Scanning}

Axial gamma scan data and measured fuel burnups have been used in the past along with to develop correlations for predicting burnups in the samples of sectioned rods and to estimate burnups in fuel rods that were not destructively analyzed. The gamma scan data also provide valuable information on fission product movement in the rod (such as cesium migration) and on densification or shifts in the fuel column.

Each fuel rod was gamma scanned axially using a germanium-lithium gamma ray detector located in D Cell of the 324 Building in the Hanford Site's 300 Area. Details on the gamma scanning equipment and procedure are provided in all ATM reports previously referenced. The same counting geometry, counting equipment, analyzing equipment, and data storage equipment were used for each measurement. As was done for gamma scans for previously reported MCC spent fuel rods, the gamma scans for the additional rods reported here were preceded and followed by gamma scans of short portions of a reference rod for the appropriate ATM.

Spectral counting for Rods NBD131 of ATM-106 and ADN0206 of ATM-108 indicated significant gamma ray peaks at $605 \mathrm{KeV}\left({ }^{134} \mathrm{Cs}\right), 662 \mathrm{KeV}\left({ }^{137} \mathrm{Cs}\right)$, and $796 \mathrm{KeV}\left({ }^{134} \mathrm{Cs}\right)$. The indicated high release in the ATM-106 rod was expected; however, the apparent fission gas release in the ATM-108 rod was not anticipated. Gamma scans for Rods MLA091 and MKP070 were consistent with low fission gas release, while Rod NBD095 appeared to have some cesium migration that indicated fission gas release. Gamma scans for each of the five rods reported are provided in Appendix A. Rod ADN1313 of ATM-108 was also gamma scanned; the plot of that data is also provided in Appendix A.

\subsection{Rod Sectioning and Sample Selection}

After gamma scanning and fission gas sampling, a sectioning diagram was prepared for each rod being characterizated. The sectioning was based on characterization plans, results of the ${ }^{137} \mathrm{Cs}$ gamma scan of the entire length of the rod, and requests by those conducting the experiments.

The sections used for radiochemical, ceramographic, and metallographic analysis were 0.60 to $2.54 \mathrm{~cm}(0.25$ to 1.0 in.) in length. Each sample was designated with an alphanumeric symbol in order of sectioning from the top of the fuel rod. Details on the sectioning process is provided in each of the previous characterization reports. Sectioning diagrams for each of the rods reported here are provided in Appendix A. The majority of the samples were taken for either radiochemical analyses or ceramographic/metallographic examinations. The estimated burnups determined using gamma scan data and the measured burnups for other samples from the same rod are provided in Tables A.1 through A.4. 


\subsection{Radiochemical Analyses}

Both radiochemical and metallographic examinations were used to characterize many of the rods reported with the intent of determining the amount and distribution of selected elements and isotopes important to the characteristics of spent fuel rods. The radiochemical analyses conducted on the cladding, the fuel, and gas samples from Rods MLA091 (ATM-103), MKP070 (ATM-104), NBD095 and NBD131 (ATM-106), and ADN0206 (ATM-108) are described below. The analyses reported for each rod are summarized in Table 4.1.

\subsection{Cladding Analyses}

Results of the radiochemical examinations of cladding are reported for analyses to determine the distribution of cesium on the exterior and interior surfaces of the cladding, the distribution of iodine on the interior surfaces of the cladding, and total ${ }^{14} \mathrm{C}$ in the cladding (i.e., in the cladding, as well as any deposits on the surfaces). Brief descriptions of the procedures used to analyze the cladding are provided in Table 4.2. The results of these examinations are shown in tabular form in Appendix B. Hydrogen in cladding samples from the lower third of Rod G13 of ATM-101 (G13B) and the top third (G13T) are reported in Appendix B, but are not listed in Table 4 for simplicity.

\subsection{Fuel Analyses}

The analyses of the fuel included determining the fuel burnup, the isotopes of uranium and plutonium, and specific nuclides including ${ }^{79} \mathrm{Se},{ }^{90} \mathrm{Sr},{ }^{99} \mathrm{Tc},{ }^{126} \mathrm{Sn},{ }^{135} \mathrm{Cs},{ }^{137} \mathrm{Cs},{ }^{237} \mathrm{~Np},{ }^{241} \mathrm{Am}$, and ${ }^{243} \mathrm{Cm}$ plus ${ }^{244} \mathrm{Cm}$. The amount of ${ }^{129} \mathrm{I},{ }^{14} \mathrm{C},{ }^{135} \mathrm{Cs}$, and ${ }^{137} \mathrm{Cs}$ in the fuel was also determined, particularly in fuels with expected fission gas release, but burnup was not directly measured for these types of samples. Procedures used to obtain these data are summarized in Table 4.3. All available results of the fuel analyses and burnup are provided in Appendix B.

Burnup is the term used to define the amount of energy obtained from the fuel during irradiation. Because fuel burnup is related to the number of fission events, each of which produces about $200 \mathrm{MeV}$ of energy, the inventory of radionuclides and other fuel characteristics are often expressed as a function of fuel burnup. Burnup samples were taken from three locations in each of the first rods characterized; typically at the middle of the rod and two other locations to get the widest variation possible in burnup.

\subsection{Gas Analyses}

After the rods were gamma scanned, the rod was punctured with a laser to obtain a gas sample in the rod plenum. The gas sample was analyzed for isotopes of xenon and krypton, ${ }^{14} \mathrm{C}$, and other possible gases, including the original helium fill gas. Available results from these analyses are provided in Table B.1 following the fuel and cladding radiochemistry results. 
Table 4.1. Summary of Section Numbers for Rods Analyzed

\begin{tabular}{|c|c|c|c|c|c|}
\hline Analyses & MLA091 & MKP070 & NBD095 & NBD131 & ADN0206 \\
\hline \multicolumn{6}{|c|}{ Fuel } \\
\hline Burnup & $\mathrm{J}$ & $\mathrm{J}, \mathrm{R}$ & $C \& D, X \& Y$ & $\mathrm{Q}, \mathrm{CC}$ & $\mathrm{D}, \mathrm{M}, \mathrm{DD}$ \\
\hline${ }^{234} \mathrm{U}$ & J & $\mathrm{J}, \mathbf{R}$ & $C \& D, X \& Y$ & $\mathrm{Q}, \mathrm{CC}$ & $\mathrm{D}, \mathrm{M}, \mathrm{DD}$ \\
\hline${ }^{235} \mathrm{U}$ & J & $\mathrm{J}, \mathrm{R}$ & $C \& D, X \& Y$ & $\mathrm{Q}, \mathrm{CC}$ & $\mathrm{D}, \mathrm{M}, \mathrm{DD}$ \\
\hline${ }^{236} \mathrm{U}$ & $\mathrm{J}$ & $\mathrm{J}, \mathrm{R}$ & $C \& D, X \& Y$ & $\mathrm{Q}, \mathrm{CC}$ & $D, M, D D$ \\
\hline${ }^{238} \mathrm{U}$ & $\mathrm{J}$ & $\mathrm{J}, \mathrm{R}$ & $C \& D, X \& Y$ & $\mathrm{Q}, \mathrm{CC}$ & $\mathrm{D}, \mathrm{M}, \mathrm{DD}$ \\
\hline${ }^{238} \mathrm{Pu}$ & $\mathrm{J}$ & $\mathrm{J}, \mathrm{R}$ & $C \& D, X \& Y$ & $\mathrm{Q}, \mathrm{CC}$ & $\mathrm{D}, \mathrm{M}, \mathrm{DD}$ \\
\hline${ }^{239} \mathrm{Pu}$ & J & $\mathrm{J}, \mathrm{R}$ & $C \& D, X \& Y$ & $\mathrm{Q}, \mathrm{CC}$ & $\mathrm{D}, \mathrm{M}, \mathrm{DD}$ \\
\hline${ }^{240} \mathrm{Pu}$ & $\mathrm{J}$ & $\mathrm{J}, \mathrm{R}$ & $C \& D, X \& Y$ & $\mathrm{Q}, \mathrm{CC}$ & $\mathrm{D}, \mathrm{M}, \mathrm{DD}$ \\
\hline${ }^{241} \mathrm{Pu}$ & $\mathrm{J}$ & $\mathrm{J}, \mathrm{R}$ & C\&D, X\&Y & $\mathrm{Q}, \mathrm{CC}$ & $\mathrm{D}, \mathrm{M}, \mathrm{DD}$ \\
\hline${ }^{242} \mathrm{Pu}$ & $\mathrm{J}$ & $\mathrm{J}, \mathrm{R}$ & $C \& D, X \& Y$ & $\mathrm{Q}, \mathrm{CC}$ & $\mathrm{D}, \mathrm{M}, \mathrm{DD}$ \\
\hline${ }^{237} \mathrm{~Np}$ & J & $\mathrm{J}, \mathbf{R}$ & $C \& D, X \& Y$ & $\mathrm{Q}, \mathrm{CC}$ & \\
\hline${ }^{241} \mathrm{Am}$ & J & $\mathrm{J}, \mathrm{R}$ & C\&D, X\&Y & $\mathrm{Q}, \mathrm{CC}$ & \\
\hline${ }^{243} \mathrm{Am}$ & $\mathrm{J}$ & $\mathrm{J}, \mathbf{R}$ & $X \& Y$ & $\mathrm{Q}, \mathrm{CC}$ & \\
\hline${ }^{242} \mathrm{Cm}$ & $\mathrm{J}$ & $\mathrm{J}, \mathrm{R}$ & C\&D, X\&Y & $\mathrm{Q}, \mathrm{CC}$ & \\
\hline${ }^{243+244} \mathrm{Cm}$ & $\mathrm{J}$ & $\mathrm{J}, \mathrm{R}$ & C\&D, X\&Y & $\mathrm{Q}, \mathrm{CC}$ & \\
\hline${ }^{79} \mathrm{Se}$ & $\mathrm{J}$ & $\mathrm{J}, \mathrm{R}$ & $C \& D, X \& Y$ & $\mathrm{Q}, \mathrm{CC}$ & \\
\hline${ }^{90} \mathrm{Sr}$ & $\mathrm{J}$ & $\mathrm{J}, \mathrm{R}$ & $C \& D, X \& Y$ & $\mathrm{Q}, \mathrm{CC}$ & \\
\hline${ }^{99} \mathrm{Tc}$ & $\mathrm{J}$ & $\mathrm{J}, \mathrm{R}$ & $C \& D, X \& Y$ & $\mathrm{Q}, \mathrm{CC}$ & \\
\hline${ }^{126} \mathrm{Sn}$ & $\mathbf{J}$ & $\mathrm{J}, \mathrm{R}$ & $C \& D, X \& Y$ & $\mathrm{Q}, \mathrm{CC}$ & \\
\hline${ }^{135} \mathrm{Cs}$ & $\mathrm{J}$ & $\mathrm{J}, \mathrm{R}$ & $\begin{array}{l}\text { C\&D, X\&Y, } \\
\text { LL }\end{array}$ & $\mathrm{Q}, \mathrm{CC}$ & \\
\hline${ }^{137} \mathrm{Cs}$ & $\mathrm{J}$ & $\mathbf{J}, \mathbf{R}$ & $\begin{array}{l}\text { C\&D, X\&Y, } \\
\text { LL }\end{array}$ & $\mathrm{Q}, \mathrm{CC}$ & \\
\hline${ }^{129} \mathrm{I}$ & $\mathrm{K}, \mathrm{O}, \mathrm{R}$ & C, $\mathrm{L}, \mathrm{S}$ & & $\begin{array}{l}\mathrm{F}, \mathrm{R}, \mathrm{W} \\
\mathrm{DD}\end{array}$ & \\
\hline${ }^{14} \mathrm{C}$ & $\mathrm{D}, \mathrm{G}, \mathrm{L}, \mathrm{P}, \mathrm{s}$ & $\mathrm{D}, \mathrm{G}, \mathrm{M}, \mathrm{P}$ & $\begin{array}{l}\mathrm{H}, \mathrm{P}, \mathrm{HH} \\
\mathrm{PP}, \mathrm{EEE}\end{array}$ & $\begin{array}{l}\mathrm{D}, \mathrm{K}, \mathrm{S}, \mathrm{X} \\
\mathrm{EE}\end{array}$ & \\
\hline${ }^{143} \mathrm{Nd} /{ }^{148} \mathrm{Nd}$ & $\mathrm{J}$ & $\mathrm{J}, \mathrm{R}$ & C\&D, X\&Y & $\mathrm{Q}, \mathrm{CC}$ & $\mathrm{D}, \mathrm{M}, \mathrm{DD}$ \\
\hline${ }^{144} \mathrm{Nd} /{ }^{148} \mathrm{Nd}$ & $\mathrm{J}$ & $\mathrm{J}, \mathrm{R}$ & $C \& D, X \& Y$ & $\mathrm{Q}, \mathrm{CC}$ & $\mathrm{D}, \mathrm{M}, \mathrm{DD}$ \\
\hline${ }^{145} \mathrm{Nd} / /^{148} \mathrm{Nd}$ & J & $\mathrm{J}, \mathrm{R}$ & $C \& D, X \& Y$ & $\mathrm{Q}, \mathrm{CC}$ & $\mathrm{D}, \mathrm{M}, \mathrm{DD}$ \\
\hline${ }^{146} \mathrm{Nd} /{ }^{148} \mathrm{Nd}$ & $\mathrm{J}$ & $\mathrm{J}, \mathbf{R}$ & $C \& D, X \& Y$ & $\mathrm{Q}, \mathrm{CC}$ & $\mathrm{D}, \mathrm{M}, \mathrm{DD}$ \\
\hline${ }^{148} \mathrm{Nd}$ & $\mathrm{J}$ & $\mathbf{J}, \mathbf{R}$ & $C \& D, X \& Y$ & $\mathrm{Q}, \mathrm{CC}$ & $\mathrm{D}, \mathrm{M}, \mathrm{DD}$ \\
\hline${ }^{150} \mathrm{Nd} /{ }^{148} \mathrm{Nd}$ & $\mathrm{J}$ & $\mathbf{J}, \mathbf{R}$ & $C \& D, X \& Y$ & $\mathrm{Q}, \mathrm{CC}$ & $\mathrm{D}, \mathrm{M}, \mathrm{DD}$ \\
\hline
\end{tabular}


Table 4.1. (contd)

\begin{tabular}{|c|c|c|c|c|}
\hline Analyses & MLA091 & MKP070 & NBD095 & NBD131 \\
\hline & \multicolumn{4}{|c|}{ Cladding Chemistry } \\
\hline${ }^{14} \mathrm{C}$ Cladding & $D, G, L, P, S$ & $\mathrm{D}, \mathrm{G}, \mathrm{M}, \mathrm{P}, \mathrm{T}$ & $\begin{array}{l}\mathrm{H}, \mathrm{P}, \mathrm{HH}, \\
\mathrm{PP}, \mathrm{EEE}\end{array}$ & $\begin{array}{l}\mathrm{D}, \mathrm{K}, \mathrm{S}, \mathrm{X} \\
\mathrm{EE}\end{array}$ \\
\hline $\begin{array}{l}{ }^{137} \mathrm{Cs} \text { on } \\
\text { cladding interior }\end{array}$ & $\mathrm{C}, \mathrm{F}, \mathrm{K}, \mathrm{O}, \mathrm{R}$ & $C, F, L, O, S$ & $\begin{array}{l}\mathrm{F}, \mathrm{K}, \mathrm{N}, \\
\mathrm{AA}, \mathrm{FF}, \\
\mathrm{MM}, \mathrm{XX}, \\
\mathrm{CCC}\end{array}$ & $\begin{array}{l}C, F, J, N, \\
R, W, Z \text {, } \\
\text { DD }\end{array}$ \\
\hline $\begin{array}{l}{ }^{135} \mathrm{Cs} \text { on } \\
\text { cladding interior }\end{array}$ & $\mathrm{C}, \mathrm{F}, \mathrm{K}, \mathrm{O}, \mathrm{R}$ & $\mathrm{C}, \mathrm{F}, \mathrm{L}, \mathrm{O}, \mathrm{S}$ & $\begin{array}{l}\mathrm{F}, \mathrm{K}, \mathrm{N}, \\
\mathrm{AA}, \mathrm{FF}, \\
\mathrm{MM}, \mathrm{XX}, \\
\mathrm{CCC}\end{array}$ & $\begin{array}{l}C, F, J, N, \\
R, W, Z, \\
D D\end{array}$ \\
\hline $\begin{array}{l}\text { I129 on } \\
\text { cladding interior }\end{array}$ & $\mathrm{C}, \mathrm{F}, \mathrm{K}, \mathrm{O}, \mathrm{R}$ & C, F, L, O, s & $\begin{array}{l}\mathrm{F}, \mathrm{K}, \mathrm{N}, \\
\mathrm{AA}, \mathrm{FF}, \\
\mathrm{MM}, \mathrm{XX}, \\
\mathrm{CCC}\end{array}$ & $\begin{array}{l}\mathrm{C}, \mathrm{F}, \mathrm{J}, \mathrm{N}, \\
\mathrm{R}, \mathrm{W}, \mathrm{Z}, \\
\mathrm{DD}\end{array}$ \\
\hline
\end{tabular}

Table 4.2. Description of Radiochemical Analysis Procedures for Cladding Samples

Analysis
${ }^{14} \mathrm{C}$
${ }^{135} \mathrm{Cs}$ Interior and
Exterior Surfaces
${ }^{137}$ Cs Interior and
Exterior Surfaces
${ }^{129} \mathrm{I}$ Interior Surface

The carbon in the cladding is evolved by total combustion in pure oxygen, the $\mathrm{CO}_{2}$ collected, and the ${ }^{14} \mathrm{C}$ measured by liquid scintillation counting. Uncertainty: $\pm 5.6 \%$.

The cesium is leached from (interior or exterior) surface and separated from other elements by chromatographic elution from a cation exchange column. Isotope abundance of cesium isotopes is determined by mass spectrometry. Uncertainty: $\pm 14 \%$.

The cesium is leached from interior or exterior surface and determined by gamma ray spectrometry on an aliquot of the leachate. Uncertainty: $\pm 3.7 \%$.

The cladding interior surface is leached in nitric acid. The iodine is separated from the nitric acid leachate by distillation and precipitation as AgI. Iodine-129 is determined in a $\mathrm{GeLi}$ well detector. Uncertainty: $\pm 2.8 \%$.

Hydrogen in Cladding

A weighed cladding sample is melted under a flowing inert cover gas and analyzed by gas chromotography. Uncertainty: $\pm 10 \%$. 
Table 4.3. Description of Radiochemical Analyses Procedures for Fuel Samples

\begin{tabular}{|c|c|}
\hline Analysis & Description \\
\hline $\begin{array}{l}\text { Burnup Sample } \\
\text { Preparation }\end{array}$ & $\begin{array}{l}\text { Weighed sample is dissolved in heated } 12 \mathrm{~N} \mathrm{HNO}_{3}(+ \text { trace } \mathrm{HF}) \text {. Solution is } \\
\text { separated from cladding and made up to } 100 \mathrm{~mL} \text {. Aliquots are taken for } \\
\text { subsequent analyses. Uncertainty: } \pm 1.0 \% \text {. (a) }\end{array}$ \\
\hline $\begin{array}{l}\text { Burnup (including } \\
\mathrm{U} \text { and } \mathrm{Pu} \text { isotopes) }\end{array}$ & $\begin{array}{l}\text { Fission product neodymium is chemically separated from irradiated fuel and } \\
\text { determined by isotopic dilution mass spectrometry. Enriched }{ }^{150} \mathrm{Nd} \text { is used as } \\
\text { the Nd isotope diluent, and mass } 142 \text { is used to determine natural } \mathrm{Nd} \\
\text { contamination. Uranium and plutonium are also determined by mass } \\
\text { spectrometry. The method uses a calibrated triple spike of }{ }^{150} \mathrm{Nd},{ }^{233} \mathrm{U} \text {, and } \\
{ }^{242} \mathrm{Pu} \text { per ANSI/ASTM Standard Test Method E321-79. Uncertainty: Atom } \% \\
\text { burnup, } \pm 2.5 \% ; \mathrm{Pu}, \pm 1.6 \% ; \mathrm{U}, \pm 1.6 \% \text {. }\end{array}$ \\
\hline${ }^{14} \mathrm{C}$ & $\begin{array}{l}\text { The carbon in a specially crushed sample of the fuel is evolved by combustion in } \\
\text { pure oxygen. The } \mathrm{CO}_{2} \text { is collected and }{ }^{14} \mathrm{C} \text { is measured by liquid scintillation } \\
\text { counting. Uncertainty: } \pm 5.6 \% \text {. }\end{array}$ \\
\hline${ }^{79} \mathrm{Se}$ & $\begin{array}{l}\text { Selenium-79 is separated from other radioactive species by passing the } \\
\text { chemically adjusted solution through a cation plus anion exchange resin column. } \\
\text { The selenium in the column effluent is distilled from hydrobromic acid and } \\
\text { precipitated as metal by reducing it with hydroxylamine hydrochloride. The } \\
\text { reduced metal is dissolved in nitric acid, and the }{ }^{79} \mathrm{Se} \text { is measured using liquid } \\
\text { scintillation counting. Uncertainty: } \pm 4.9 \% \text {. }\end{array}$ \\
\hline${ }^{90} \mathrm{Sr}$ & $\begin{array}{l}\text { The }{ }^{90} \mathrm{Sr} \text { is separated from other radioactive species by selective elution from a } \\
\text { cation exchange resin using } 2 \text {-methyllactic acid. Following separation, the } \\
\text { growth of }{ }^{90} \mathrm{Y} \text { is measured by beta counting. The }{ }^{90} \mathrm{Sr} \text { is then calculated based } \\
\text { on the growth of the }{ }^{90} \mathrm{Y} \text { radioactive decay product over a specific time. } \\
\text { Uncertainty: } \pm 5.7 \% \text {. }\end{array}$ \\
\hline${ }^{99} \mathrm{Tc}$ & $\begin{array}{l}\text { Technetium is separated from other radioactive species by a process that absorbs } \\
\text { most other species on to a cation exchange resin. The technetium is extracted } \\
\text { from the effluent into hexone as tetraphenylarsonium pertechnetate. The } \\
\text { technetium activity is then measured by beta counting. Uncertainty: } \pm 3.5 \% \text {. }\end{array}$ \\
\hline${ }^{129} \mathrm{I}$ & $\begin{array}{l}\text { Iodine is separated by distillation and precipitation as AgI. Iodine-129 is } \\
\text { determined in a GeLi well detector. Uncertainty: } \pm 2.2 \% \text {. }\end{array}$ \\
\hline${ }^{126} \mathrm{Sn}$ & $\begin{array}{l}\text { Tin is separated by a combination of cation and anion exchange resins. Tin is } \\
\text { finally eluted with dilute nitric acid and measured using a GeLi gamma spectro- } \\
\text { meter. Uncertainty: } \pm 10.2 \% \text {. }\end{array}$ \\
\hline
\end{tabular}


Table 4.3. (contd)

Analysis

${ }^{135} \mathrm{Cs}$

${ }^{137} \mathrm{Cs}$

${ }^{237} \mathrm{~Np}$

${ }^{241} \mathrm{Am},{ }^{243} \mathrm{Cm}$ plus

${ }^{244} \mathrm{Cm}$
Description

Cesium is separated from other elements by chromatographic elution from a cation exchange column. Isotopic abundance of the cesium isotope is determined by mass spectrometry. Uncertainty: $\pm 14 \%$.

The cesium is determined by gamma ray spectrometry on an aliquot of the aqueous solution. Uncertainty: $\pm 3.5 \%$.

Neptunium-237 is separated from other radionuclides species by extraction into a mixture of tri-iso-octyl-amine (TiOA) in xylene, stripped from the TiOA phase with $\mathrm{HCl}$ and re-extraction into a mixture of thenoyltrifluoracetone (TTA) in xylene for additional separation. Neptunium-237 is measured by alpha counting. $A^{239} \mathrm{~Np}$ tracer is added to the sample and gamma-counted to determine a recovery factor. Uncertainty: $\pm 1.9 \%$.

Americium and curium are separated using cation and anion exchange and determined by alpha spectrometry. Uncertainty: ${ }^{241} \mathrm{Am}, \pm 4.9 \% ;{ }^{243} \mathrm{Cm}$ plus ${ }^{244} \mathrm{Cm}, \pm 4.1 \%$.

(a) Uncertainties are one relative standard deviation that is based on experience in the laboratory at PNL.

Previous estimates of the fission gas release were made for the rods based on the gas sample volumes, the approximate rod-average burnup, and assuming $31.0 \mathrm{~cm}^{3}$ of fission gas was generated for each MWd of fuel at STP (SSA 1982). Examples of these calculations are provided in characterization reports, such as Guenther et al. (1991a). No records were found to verify the calculated fission gas releases for these rods, but nonrecord information provides a valuable reference for the fission gas releases from these rods and is summarized in Table 4.4. All other data were obtained in accordance with Impact Level I of PNL-MA-70 and meet the criteria of NQA-1 quality assurance. 
Table 4.4. Estimated Fission Gas Releases from Characterized Rods

\begin{tabular}{|c|c|c|}
\hline Rod Number & $\begin{array}{c}\text { Estimated Rod-Average } \\
\text { Burnup, MWd/kgM }\end{array}$ & $\begin{array}{c}\text { Estimated Fission } \\
\text { Gas Release, \% }\end{array}$ \\
\hline MLA091 & 28 & $<1$ \\
\hline MKP070 & 38 & $<1$ \\
\hline NBD095 & 40 & 7 \\
\hline NBD131 & 46 & 18 \\
\hline ADN0206 & 24 & 9 \\
\hline
\end{tabular}




\subsection{References}

Barner, J. O. 1985. Characterization of LWR Spent Fuel MCC-Approved Testing Material ATM-101. PNL-5109, Rev. 1, Pacific Northwest Laboratory, Richland, Washington.

Guenther, R. J., D. E. Blahnik, T. K. Campbell, U. P. Jenquin, J. E. Mendel, L. E. Thomas, and C. K. Thornhill. 1988a. Characterization of Spent Fuel Approved Testing Material-ATM-103. PNL-5109-103, Pacific Northwest Laboratory, Richland, Washington.

Guenther, R. J., D. E. Blahnik, T. K. Campbell, U. P. Jenquin, J. E. Mendel, and C. K. Thornhill. 1988b. Characterization of Spent Fuel Approved Testing Material-ATM-106. PNL-5109-106, Pacific Northwest Laboratory, Richland, Washington.

Guenther, R. J., D. E. Blahnik, U. P. Jenquin, J. E. Mendel, L. E. Thomas, and C. K. Thornhill. 1991a. Characterization of Spent Fuel Approved Testing Material-ATM-104. PNL-5109-104, Pacific Northwest Laboratory, Richland, Washington.

Guenther, R. J., D. E. Blahnik, T. K. Campbell, U. P. Jenquin, J. E. Mendel, L. E. Thomas, and C. K. Thornhill. 1991b. Characterization of Spent Fuel Approved Testing Material-ATM-105. PNL-5109-105, Pacific Northwest Laboratory, Richland, Washington.

McKinnon, M. A., J. W. Doman, J. E. Tanner, R. J. Guenther, J. M. Creer, and C. E. King. 1986. BWR Spent Fuel Storage Cask Performance Test, Vol. I, Cask Handling Experience and Decay Heat, Heat Transfer, and Shielding Data. PNL-5777, Vol 1., Pacific Northwest Laboratory, Richland, Washington. NNA.900404.0136.

SSA (Southern Science Applications, Inc.). 1982. Background and Derivation of ANS 5.4 Standard Fission Product Release Model. NUREG/CR-2507, U.S. Nuclear Regulatory Commission, Washington, D.C. NNA.910410.0160. 


\section{Appendix A}

\section{Gamma Scans and Sectioning Diagrams}




\section{Appendix A}

\section{Gamma Scans and Sectioning Diagrams}

Full-length gamma scans were made of each of the rods receiving examination. The gamma scan was used to determine the location of appropriate samples and for estimating the burnup in samples for which actual measurements were not made. The gamma scans for Rods MLA091, MKP070, NBD095, NBD131, and ADN0206 are provided in Figures A.1 through A.5. A gamma scan of ATM-108 Rod ADN1313 was also made and is shown in Figure A.6. The samples taken from five rods destructively examined are listed in Tables A.1 through A.4 and include the average cesium activity for each sample along with the estimated burnups. The sectioning diagrams for Rods MLA091, MKP070, NBD095, NBD095, NBD131, and ADN0206 are provided in Figures A.7 through A.11, respectively. Not all of the samples taken were analyzed or delivered to those conducting the experiments. 
Distance from Top, in.

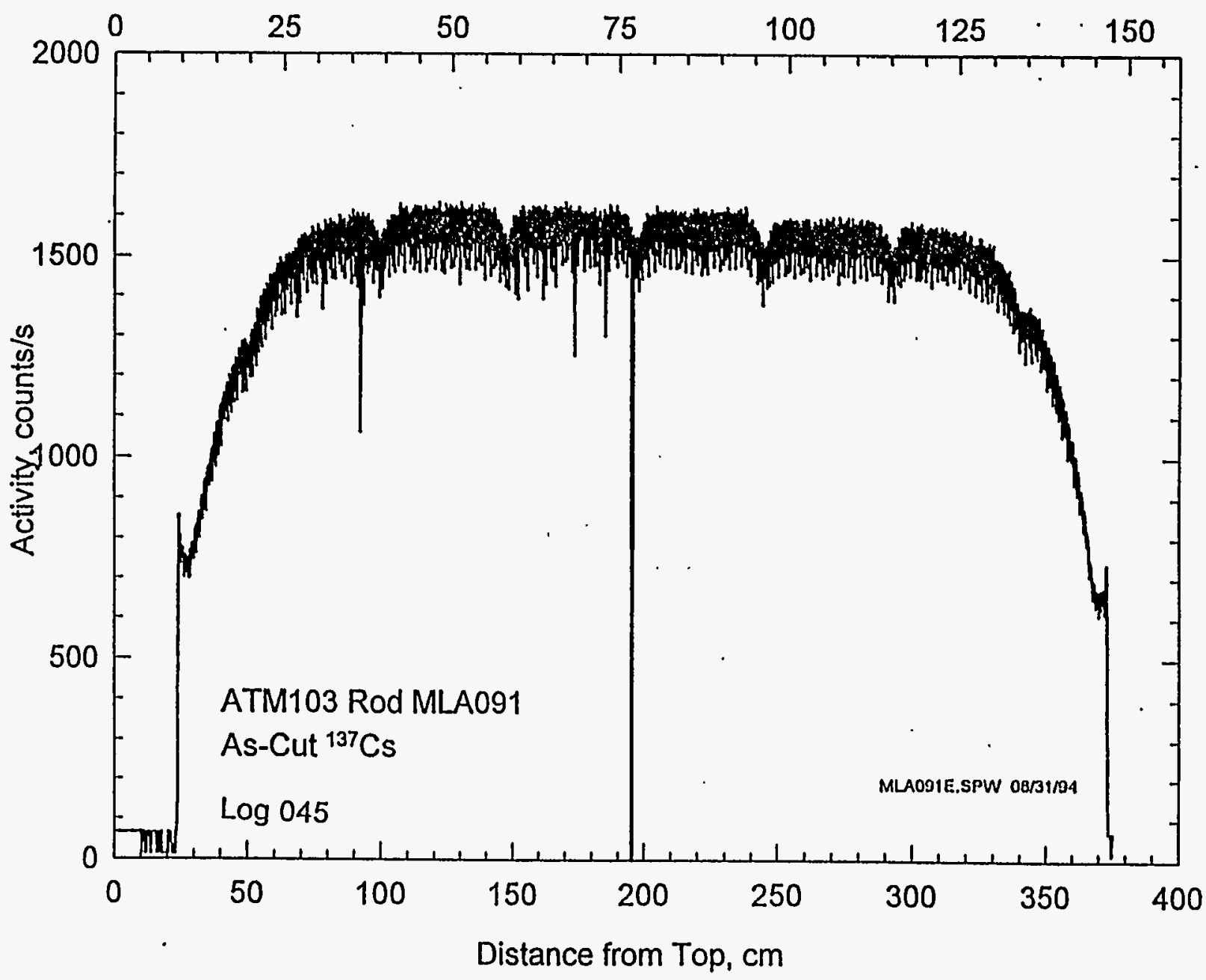

Figure A.1. Gamma Scan of Rod MLA091 of ATM-130 


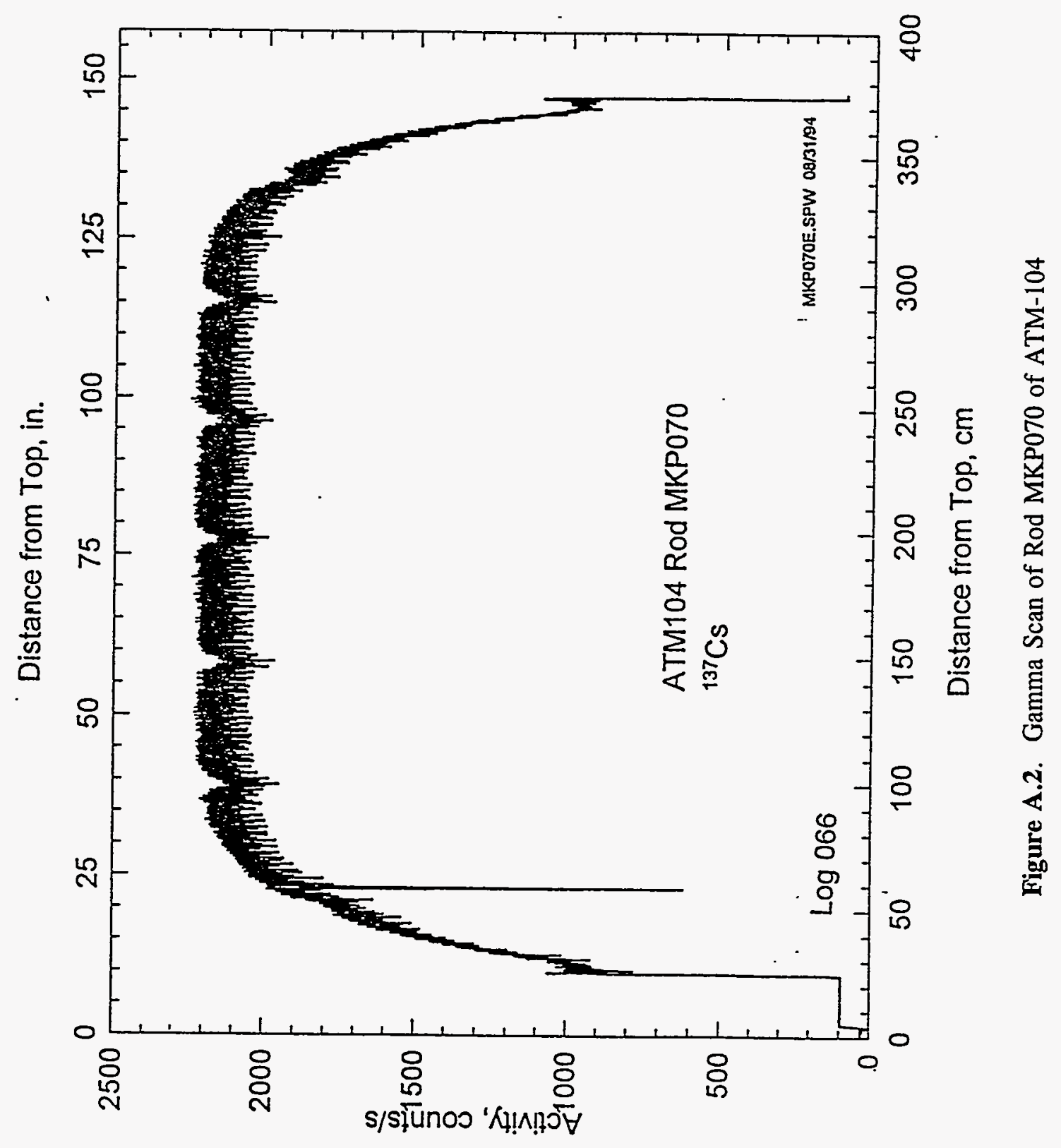

A. 3 


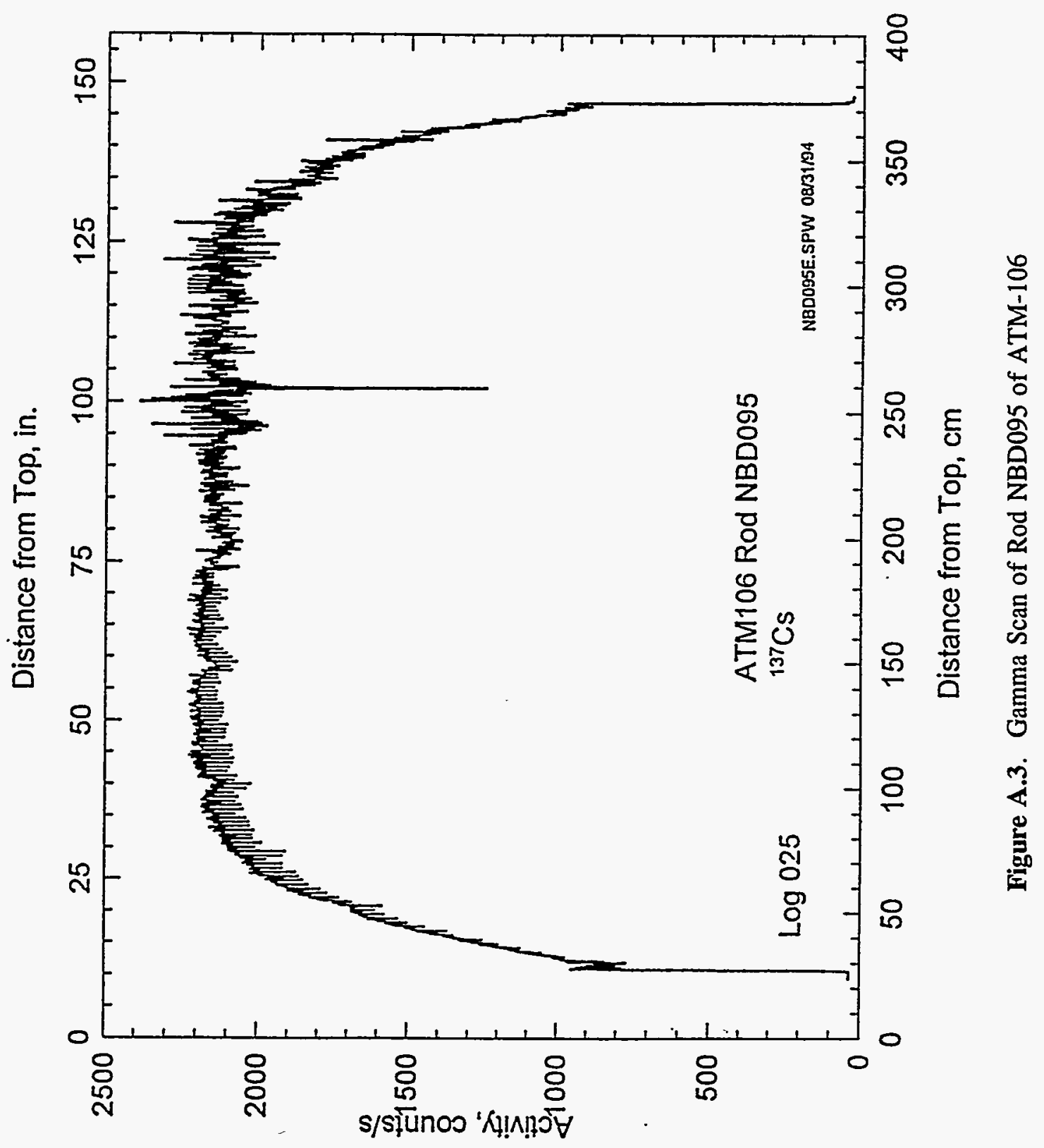

A. 4 


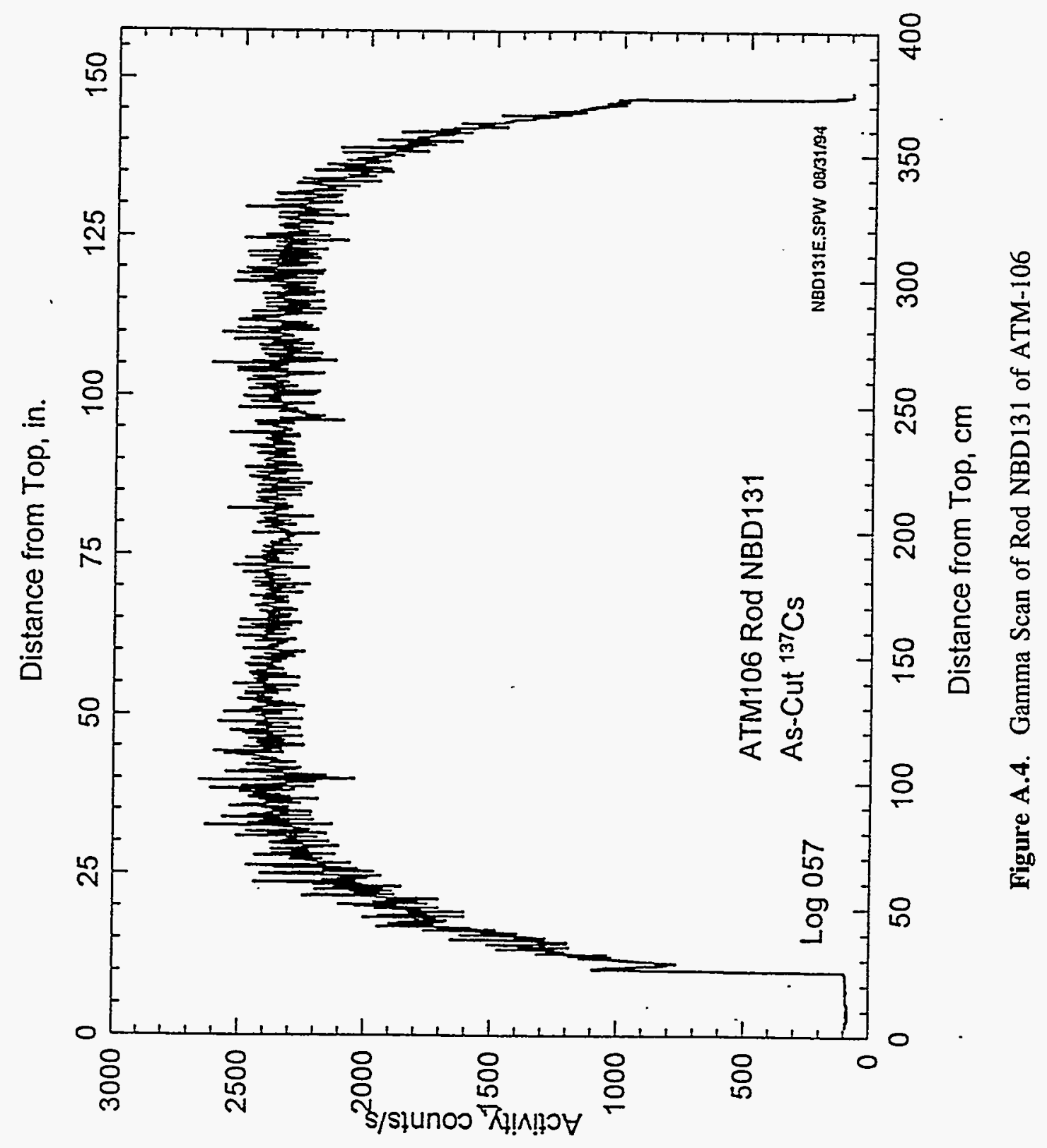

A. 5 


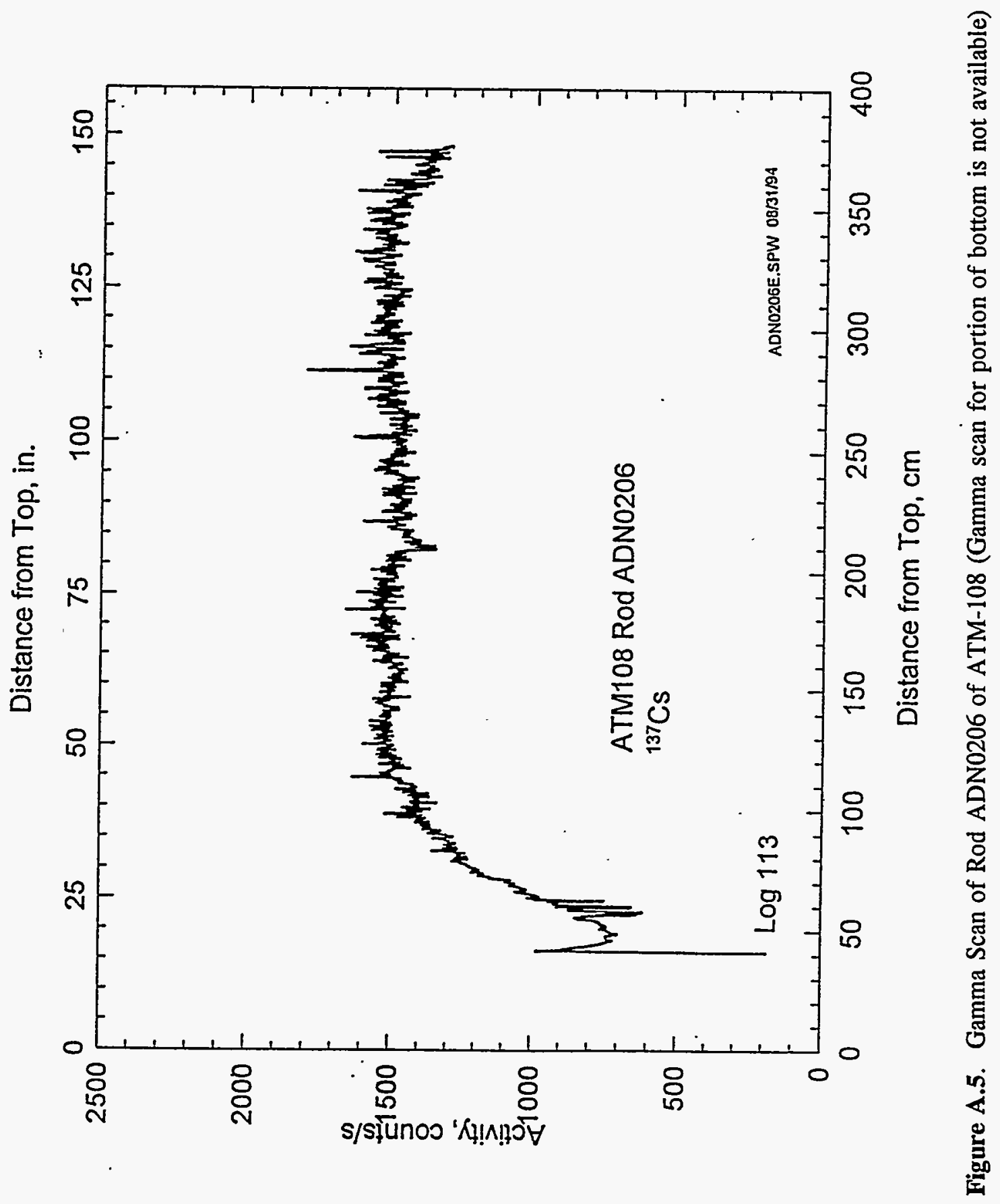

A. 6 


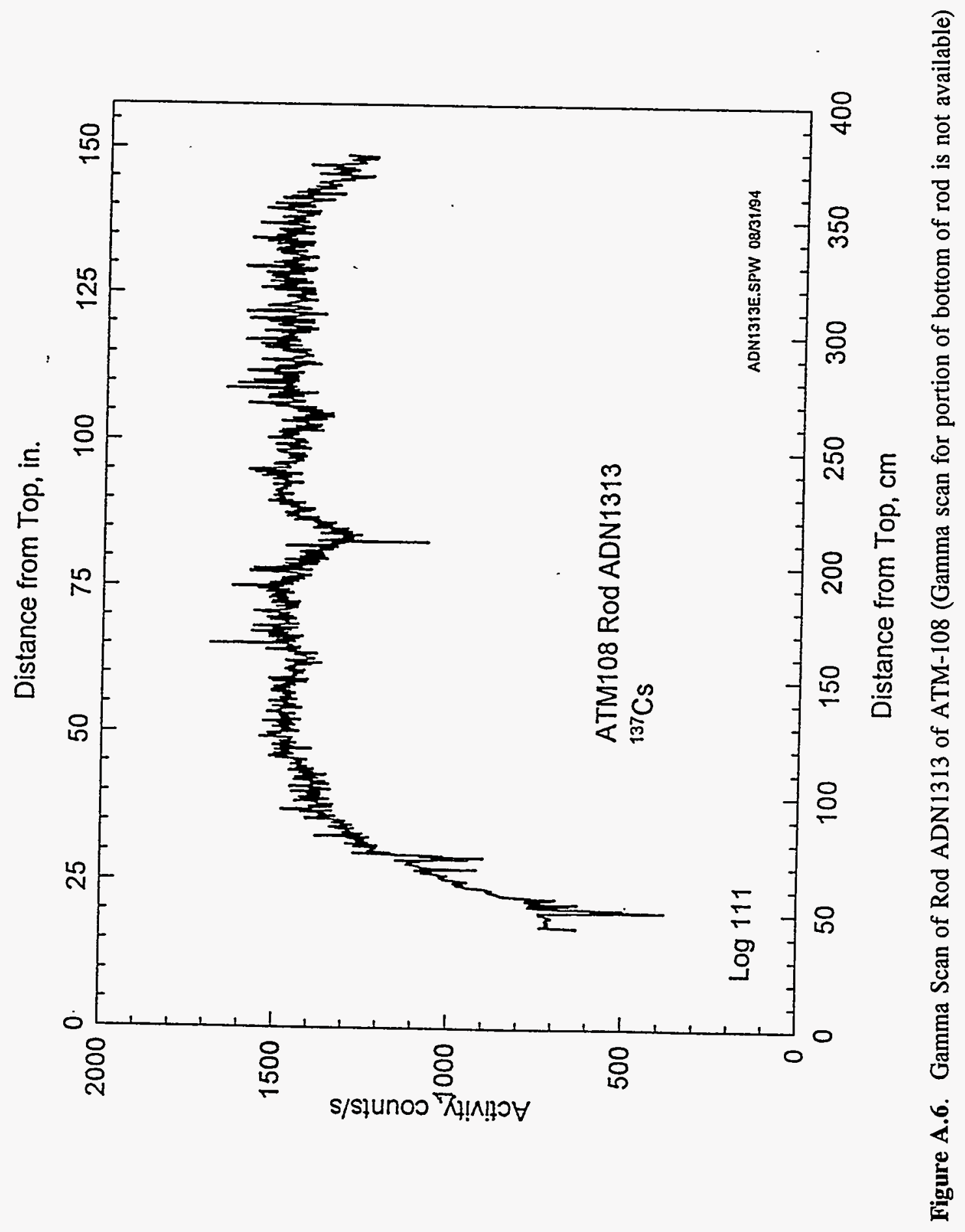

A. 7 
Table A.1. Cesium-137 Activities and Estimated Burnups for Rod MLA091

\begin{tabular}{|c|c|c|c|}
\hline Section Identification & Section Assignment & $\begin{array}{c}\text { Original Activity } \\
\text { Counts/s }\end{array}$ & $\begin{array}{c}\text { Burnup, MWd/KgM } \\
\text { (Measured) }\end{array}$ \\
\hline 103-MLA091-A & MCC Spare Material & 393.3 & 6.5 \\
\hline 103-MLA091-B & $\begin{array}{l}\text { MCC Transverse Metallography- } \\
\text { Ceramography }\end{array}$ & 1143.6 & 22.5 \\
\hline 103-MLA091-C & $\begin{array}{l}\mathrm{MCC}{ }^{129} \mathrm{I} \text { on Cladding } \mathrm{D}, \mathrm{MCC} \\
{ }^{135} \mathrm{Cs} \text { and }{ }^{137} \mathrm{Cs} \text { on Cladding ID }\end{array}$ & 1177.8 & 23.2 \\
\hline 103-MLA091-D & MCC ${ }^{14} \mathrm{C}$ in Fuel and Cladding & 1208.9 & 23.8 \\
\hline 103-MLA091-E & MCC Spare and Archive Material & 1508.2 & 30.2 \\
\hline 103-MLA091-F & $\begin{array}{l}\text { MCC }{ }^{129} \mathrm{I} \text { on Cladding ID, MCC } \\
{ }^{135} \mathrm{Cs} \text { and }{ }^{137} \mathrm{Cs} \text { on Cladding ID }\end{array}$ & 1590.5 & 32.0 \\
\hline 103-MLA091-G & MCC ${ }^{14} \mathrm{C}$ in Fuel and Cladding & 1586.6 & 31.9 \\
\hline 103-MLA091-H & MCC Spare Material & $1580.4^{(a)}$ & 31.7 \\
\hline 103-MLA091-I & $\begin{array}{l}\text { MCC Transverse Metallography- } \\
\text { Ceramography }\end{array}$ & 1592.9 & 32.0 \\
\hline 103-MLA091-J & $\begin{array}{l}\text { MCC Burnup, Isotopes, and } \\
\text { Radionuclides }\end{array}$ & 1601.2 & $32.2(32.91)$ \\
\hline 103-MLA091-K & $\begin{array}{l}\mathrm{MCC}{ }^{129} \mathrm{I} \text { in Fuel and on } \\
\text { Cladding ID, MCC }{ }^{135} \mathrm{Cs} \text { and } \\
{ }^{137} \mathrm{Cs} \text { on Cladding ID }\end{array}$ & 1583.5 & 31.8 \\
\hline 103-MLA091-L & MCC ${ }^{14} \mathrm{C}$ in Fuel and Cladding & 1581.7 & 31.8 \\
\hline 103-MLA091-M & MCC Spare and Archive Material & 1569.6 & 31.5 \\
\hline 103-MLA091-N & MCC Spare Material & 1495.1 & 29.9 \\
\hline 103-MLA091-O & $\begin{array}{l}\mathrm{MCC}{ }^{129} \mathrm{I} \text { in Fuel and on } \\
\text { Cladding ID, MCC }{ }^{135} \mathrm{Cs} \text { and } \\
{ }^{137} \mathrm{Cs} \text { on Cladding ID }\end{array}$ & 1285.4 & 25.5 \\
\hline 103-MLA091-P & $\mathrm{MCC}{ }^{14} \mathrm{C}$ in Fuel and Cladding & 1246.0 & 24.6 \\
\hline 103-MLA091-Q & MCC Spare Material & 1095.7 & 21.4 \\
\hline 103-MLA091-R & $\begin{array}{l}\text { MCC }{ }^{129} \mathrm{I} \text { in Fuel and on } \\
\text { Cladding ID, MCC }{ }^{135} \mathrm{Cs} \text { and } \\
{ }^{137} \mathrm{Cs} \text { on Cladding ID }\end{array}$ & 863.7 & 16.5 \\
\hline
\end{tabular}


Table A.1. (contd)

\begin{tabular}{|c|c|c|c|}
\hline Section Identification & Section Assignment & $\begin{array}{c}\text { Original Activity } \\
\text { Counts/s }\end{array}$ & $\begin{array}{c}\text { Burnup, MWd/KgM } \\
\text { (Measured) }\end{array}$ \\
\hline 103-MLA091-S & $\mathrm{MCC}{ }^{14} \mathrm{C}$ in Fuel and Cladding & 761.6 & 14.3 \\
\hline 103-MLA091-T & MCC Spare Material & 523.7 & 9.3 \\
\hline \multicolumn{4}{|c|}{$\begin{array}{l}\text { (a) At } 76.800,76.900 \text {, and } 77.000 \text { in. from the top of the rod, the Cesium- } 137 \text { activity was an } \\
\text { unreasonable } 0.0 \text { counts/s. Had the average activity of Cesium-137 been calculated without } \\
\text { correcting the } 0.0 \text { values to more reasonable numbers, Section } H \text { would have shown a lower } \\
\text { average Cesium- } 137 \text { activity than what would have been expected. The } 0.0 \text { values were } \\
\text { corrected by averaging the counts/s of the data point } 0.3 \text { in. above and } 0.3 \text { in. below the } \\
76.800 \text {-in., } 76.900 \text {-in., and } 77.000 \text {-in. points, the corrected averages being } 1529.4,1522.2 \text {, } \\
\text { and } 1558.6 \text {, respectively. Then the average Cesium- } 137 \text { in counts/s was calculated using } \\
\text { simple averaging techniques with program AREA. }\end{array}$} \\
\hline Note: & $\begin{array}{l}\text { tained from AREA for each secti } \\
\text { table and then used to find the bu } \\
\text { only section where the burnup was } \\
\text { ILA091 ( } 32.91 \text { ) and the burnup e } \\
\text { and activity over Section J whic } \\
\text { burnup into the equation and sc }\end{array}$ & $\begin{array}{l}\text { have been correct } \\
\text { lups shown in this } \\
\text { neasured, the knon } \\
\text { lation, } \mathrm{BU}=0.0212 \\
\text { was } 1635.2 \text {. This } \\
\text { ing for the activity }\end{array}$ & $\begin{array}{l}\text { ed by the multiplier } \\
\text { table. Since Sec- } \\
\text { n burnup over Sec- } \\
6 \text { A- } 1.855 \text {, were } \\
\text { was done by insert- } \\
\text { (A). }\end{array}$ \\
\hline \multicolumn{4}{|c|}{$\begin{array}{l}\text { Then an average activity of } 1620 \text { was found graphically over Section J and divided into } 1635.2 \text {. } \\
\text { This determined the multiplier (1.0094) that would correct the activity of the scan of Rod } \\
\text { MLA091, which was scanned December } 11,1987 \text {, to what it should have been had Rod MLA091 } \\
\text { been scanned the same time Rod MLA098 had been scanned (i.e., March 5, 1987). }\end{array}$} \\
\hline
\end{tabular}


Table A.2. Cesium-137 Activities and Estimated Burnups for Rod MK070

\begin{tabular}{|c|c|c|c|}
\hline Section Identification & Section Assignment & $\begin{array}{c}\text { Original Activity } \\
\text { Counts/s }\end{array}$ & $\begin{array}{l}\text { Burnup, MWd/KgM } \\
\text { (Measured) }\end{array}$ \\
\hline 104-MKP070-A & MCC Spare Material & 526.5 & 4.9 \\
\hline 104-MKP070-B & $\begin{array}{l}\text { MCC Transverse Metallography- } \\
\text { Ceramography }\end{array}$ & 1574.5 & 29.0 \\
\hline 104-MKP070-C & $\begin{array}{l}\text { MCC }{ }^{129} \mathrm{I} \text { in Fuel and on } \\
\text { Cladding ID, MCC }{ }^{135} \mathrm{Cs} \text { and } \\
{ }^{137} \mathrm{Cs} \text { on Cladding ID }\end{array}$ & 1622.1 & 30.0 \\
\hline 104-MKP070-D & $\mathrm{MCC}{ }^{14} \mathrm{C}$ in Fuel and Cladding & 1670.7 & 31.2 \\
\hline 104-MKP070-E & MCC Spare and Archive Material & $2053.0^{(a)}$ & 39.9 \\
\hline 104-MKP070-F & $\begin{array}{l}\text { MCC }{ }^{129} \mathrm{I} \text { on Cladding ID, MCC } \\
{ }^{135} \mathrm{Cs} \text { and }{ }^{137} \mathrm{Cs} \text { on Cladding ID }\end{array}$ & 2170.3 & 42.6 \\
\hline 104-MKP070-G & MCC ${ }^{14} \mathrm{C}$ in Fuel and Cladding & 2166.1 & 42.5 \\
\hline 104-MKP070-H & MCC Spare Material & 2163.8 & 42.5 \\
\hline 104-MKP070-I & $\begin{array}{l}\text { MCC Transverse Metallography- } \\
\text { Ceramography }\end{array}$ & 2176.4 & 42.8 \\
\hline 104-MKP070-J & $\begin{array}{l}\text { MCC Burnup, Isotopes, and } \\
\text { Radionuclides }\end{array}$ & 2175.3 & $42.7(43.75)$ \\
\hline 104-MKP070-K1 & ORNL Comparative Analysis & 2162.2 & 42.4 \\
\hline 104-MKР070-К2 & ORNL Comparative Analysis & 2167.9 & 42.6 \\
\hline 104-MKP070-K3 & ORNL Comparative Analysis & 2179.3 & 42.8 \\
\hline 104-MKP070-K4 & ORNL Comparative Analysis & 2202.6 & 43.4 \\
\hline 104-MKP070-L & $\begin{array}{l}\text { MCC }{ }^{129} \mathrm{I} \text { in Fuel and on } \\
\text { Cladding ID, MCC }{ }^{135} \mathrm{Cs} \text { and } \\
{ }^{137} \mathrm{Cs} \text { on Cladding ID }\end{array}$ & 2188.1 & 43.0 \\
\hline 104-MKP070-M & MCC ${ }^{14} \mathrm{C}$ in Fuel and Cladding & 2173.4 & 42.7 \\
\hline 104-MKP070-N & MCC Spare and Archive Material & 2170.8 & 42.6 \\
\hline 104-MKP070-O & $\begin{array}{l}\mathrm{MCC}{ }^{129} \mathrm{I} \text { on Cladding ID, MCC } \\
{ }^{135} \mathrm{Cs} \text { and }{ }^{137} \mathrm{Cs} \text { on Cladding ID }\end{array}$ & 2173.1 & 42.7 \\
\hline 104-MKP070-P & $\mathrm{MCC}{ }^{14} \mathrm{C}$ in Fuel and Cladding & 2180.8 & 42.9 \\
\hline 104-MKP070-Q & MCC Spare Material & 2002.9 & 38.9 \\
\hline
\end{tabular}


Table A.2. (contd)

\begin{tabular}{|c|c|c|c|c|}
\hline \multicolumn{2}{|c|}{ Section Identification } & Section Assignment & $\begin{array}{c}\text { Original Activity } \\
\text { Counts/s }\end{array}$ & $\begin{array}{l}\text { Burnup, } \mathrm{MWd} / \mathrm{KgM} \\
\text { (Measured) }\end{array}$ \\
\hline \multicolumn{2}{|c|}{ 104-MKP070-R } & $\begin{array}{l}\text { MCC Burnup, Isotopes, and } \\
\text { Radionuclides }\end{array}$ & 1366.5 & $24.2(24.96)$ \\
\hline \multicolumn{2}{|c|}{ 104-MKP070-S } & $\begin{array}{l}\text { MCC }{ }^{129} \mathrm{I} \text { in Fuel and on } \\
\text { Cladding ID, MCC }{ }^{135} \mathrm{Cs} \text { and } \\
{ }^{137} \mathrm{Cs} \text { on Cladding ID }\end{array}$ & 1256.3 & 21.7 \\
\hline \multicolumn{2}{|c|}{ 104-MKP070-T } & $\mathrm{MCC}{ }^{14} \mathrm{C}$ in Fuel and Cladding & 1117.5 & 18.5 \\
\hline \multicolumn{2}{|c|}{ 104-MKP070-U } & MCC Spare Material & 816.2 & 11.6 \\
\hline \multicolumn{5}{|c|}{$\begin{array}{l}\text { (a) In the data file MKP070.2ND, at } 23.050 \text { in. from the top of the rod, the Cesium-137 activity } \\
\text { drops to an unreasonable } 620.2 \text { counts/s. The } 620.2 \text { was replaced with } 1978.2 \text {, which was an } \\
\text { average of the measured Cesium-137 activity at } 23.250 \text { in. (1984.0) and } 22.850 \text { in. (1972.5) } \\
\text { in the data file. Then the average activity over the entire section was calculated using the } \\
\text { program AREA (code custodian NJ Wildung) with the corrected value } 1978.2 \text { in place of } \\
620.2 \text { counts/s at } 23.050 \text { in. from the top of the rod. }\end{array}$} \\
\hline Note: & \multicolumn{4}{|c|}{$\begin{array}{l}\text { The burnups were calculated using the burnup equation } B U=0.02294 \mathrm{~A}-7.16 \text {. The } \\
\text { burnup equation was formulated by plotting the known burnups of Sections } \mathrm{J} \text { and } \mathrm{R} \\
\text { against the measured Cesium-137 activity over the two sections which were found } \\
\text { graphically ( } 2219.1 \text { counts/s over Section J and } 1400.0 \text { over Section } \mathrm{R} \text { ). Then the linear } \\
\text { burnup equation was found that related the burnup as a function of Cesium- } 137 \text { activity so } \\
\text { that the burnup over any section of the rod could be estimated by knowing the Cesium- } \\
137 \text { activity over the section. }\end{array}$} \\
\hline
\end{tabular}

\section{A.11}


Table A.3. Cesium-137 Activities and Estimated Burnups for Rod NBD095

\begin{tabular}{|c|c|c|c|}
\hline $\begin{array}{c}\text { Section } \\
\text { Identification }\end{array}$ & Section Assignment & $\begin{array}{c}\text { Original Activity } \\
\text { Counts/s }\end{array}$ & $\begin{array}{c}\text { Burnup, MWd/KgM } \\
\text { (Measured) }\end{array}$ \\
\hline 106-NBD095-A & MCC Spare Material & 706.6 & 12.5 \\
\hline 106-NBD095-B & $\begin{array}{l}\text { ORNL Spark Source and Mass } \\
\text { Spectrometry }\end{array}$ & 1236.1 & 24.6 \\
\hline 106-NBD095-C & $\begin{array}{l}\text { ORNL Spark Source and Mass } \\
\text { Spectrometry } \\
\text { (a) }\end{array}$ & 1307.3 & 26.2 \\
\hline 106-NBD095-D & $\begin{array}{l}\text { MCC Burnup, Isotopes, and } \\
\text { Radionuclides }^{(\mathrm{a})}\end{array}$ & 1359.0 & $27.4(27.42)$ \\
\hline 106-NBD095-E & $\mathrm{MCC}{ }^{3} \mathrm{H}$ in Cladding & 1398.8 & 28.3 \\
\hline 106-NBD095-F & $\begin{array}{l}\mathrm{MCC}{ }^{129} \mathrm{I} \text { in Fuel and on Cladding } \\
\mathrm{I}, \mathrm{MCC}{ }^{135} \mathrm{Cs} \text { and }{ }^{137} \mathrm{Cs} \text { on } \\
\text { Cladding ID; Hydrogen in Cladding }\end{array}$ & 1470.3 & 30.0 \\
\hline 106-NBD095-G & $\begin{array}{l}\text { MCC Transverse Metallography- } \\
\text { Ceramography }\end{array}$ & 1551.1 & 31.8 \\
\hline 106-NBD095-H & $\mathrm{MCC}{ }^{14} \mathrm{C}$ in Fuel and Cladding & 1566.9 & 32.2 \\
\hline 106-NBD095-I & MCC Spare and Archive Material & 1763.2 & 36.7 \\
\hline 106-NBD095-J & $\mathrm{MCC}{ }^{3} \mathrm{H}$ in Cladding & 1920.8 & 40.3 \\
\hline 106-NBD095-K & $\begin{array}{l}\text { MCC }{ }^{129} \mathrm{I} \text { in Fuel and on Cladding } \\
\text { ID, MCC }{ }^{135} \mathrm{Cs} \text { and }{ }^{137} \mathrm{Cs} \text { on } \\
\text { Cladding } \mathrm{D} \text {; Hydrogen in Cladding }\end{array}$ & 1976.4 & 41.5 \\
\hline 106-NBD095-L & MCC Spare Material & 2055.8 & 43.3 \\
\hline 106-NBD095-M & MCC ${ }^{3} \mathrm{H}$ in Cladding & 2125.5 & 44.9 \\
\hline $106-N B D 095-N$ & $\begin{array}{l}\text { MCC }{ }^{129} \mathrm{I} \text { in Fuel and on Cladding } \\
\text { ID, MCC }{ }^{135} \mathrm{Cs} \text { and }{ }^{137} \mathrm{Cs} \text { on } \\
\text { Cladding ID; Hydrogen in Cladding }\end{array}$ & 2117.5 & 44.7 \\
\hline 106-NBD095-O & $\begin{array}{l}\text { MCC Transverse Metallography- } \\
\text { Ceramography }\end{array}$ & 2122.6 & 44.9 \\
\hline 106-NBD095-P & $\mathrm{MCC}{ }^{14} \mathrm{C}$ in Fuel and Cladding & 2133.5 & 45.1 \\
\hline 106-NBD095-Q & MCC Spare and Archive Material & 2161.5 & 45.7 \\
\hline 106-NBD095-R & MCC Acid Etch Assay & 2190.8 & 46.6 \\
\hline 106-NBD095-S & MCC Acid Etch Assay & 2169.4 & 45.9 \\
\hline
\end{tabular}


Table A.3. (contd)

\begin{tabular}{|c|c|c|c|}
\hline $\begin{array}{c}\text { Section } \\
\text { Identification }\end{array}$ & Section Assignment & $\begin{array}{l}\text { Original Activity } \\
\text { Counts/s }\end{array}$ & $\begin{array}{l}\text { Burnup, MWd/KgM } \\
\text { (Measured) }\end{array}$ \\
\hline 106-NBD095-T & MCC Acid Etch Assay & 2176.0 & 46.1 \\
\hline 106-NBD095-U & MCC Acid Etch Assay & 2193.5 & 46.5 \\
\hline 106-NBD095-V & MCC Acid Etch Assay & 2197.7 & 46.6 \\
\hline 106-NBD095-W & $\begin{array}{l}\text { ORNL Spark Source and Mass } \\
\text { Spectrometry }\end{array}$ & 2183.0 & 46.2 \\
\hline 106-NBD095-X & $\begin{array}{l}\text { ORNL Spark Source and Mass } \\
\text { Spectrometry }\end{array}$ & 2177.1 & 46.1 \\
\hline 106-NBD095-Y & $\begin{array}{l}\text { MCC Burnup, Isotopes, and } \\
\text { Radionuclides } \\
\text { (a) }\end{array}$ & 2205.3 & $46.7(46.75)$ \\
\hline 106-NBD095-Z & $\mathrm{MCC}{ }^{3} \mathrm{H}$ in Cladding & 2205.5 & 46.8 \\
\hline 106-NBD095-AA & $\begin{array}{l}\text { MCC }{ }^{129} \mathrm{I} \text { in Fuel and on Cladding } \\
\mathrm{ID}, \mathrm{MCC}{ }^{135} \mathrm{Cs} \text { and }{ }^{137} \mathrm{Cs} \text { on } \\
\text { Cladding ID; Hydrogen in Cladding }\end{array}$ & 2184.3 & 46.3 \\
\hline 106-NBD095-BB & $\begin{array}{l}\text { MCC Transverse Metallography- } \\
\text { Ceramography }\end{array}$ & 2205.2 & 46.7 \\
\hline 106-NBD095-CC & MCC GGBI Sample & 2207.0 & 46.8 \\
\hline 106-NBD095-CC-2 & MCC GGBI Sample & 2186.6 & 46.3 \\
\hline 106-NBD095-DD & MCC Spare Material & 2162.2 & 45.8 \\
\hline 106-NBD095-EE & $\mathrm{MCC}^{3} \mathrm{H}$ in Cladding & 2156.6 & 45.6 \\
\hline 106-NBD095-FF & $\begin{array}{l}\text { MCC }{ }^{129} \mathrm{I} \text { in Fuel and on Cladding } \\
\mathrm{ID} \text {, MCC }{ }^{135} \mathrm{Cs} \text { and }{ }^{137} \mathrm{Cs} \text { on } \\
\text { Cladding ID; Hydrogen in Cladding }\end{array}$ & 2145.4 & 45.4 \\
\hline 106-NBD095-GG & $\begin{array}{l}\text { MCC Transverse Metallography- } \\
\text { Ceramography }\end{array}$ & 2133.5 & 45.1 \\
\hline 106-NBD095-HH & $\mathrm{MCC}{ }^{14} \mathrm{C}$ in Fuel and Cladding & 2112.2 & 44.6 \\
\hline 106-NBD095-II & MCC Spare and Archive Material & 2132.0 & 45.1 \\
\hline 106-NBD095-JJ & MCC GGBI Sample & 2134.3 & 45.1 \\
\hline 106-NBD095-KK & $\mathrm{MCC}{ }^{3} \mathrm{H}$ in Cladding & 2152.0 & 45.5 \\
\hline 106-NBD095-LL & $\mathrm{MCC}{ }^{135} \mathrm{Cs}$ and ${ }^{137} \mathrm{Cs}$ in Fuel & 2135.8 & 45.2 \\
\hline
\end{tabular}


Table A.3. (contd)

\begin{tabular}{|c|c|c|c|}
\hline $\begin{array}{c}\text { Section } \\
\text { Identification }\end{array}$ & Section Assignment & $\begin{array}{c}\text { Original Activity } \\
\text { Counts/s }\end{array}$ & $\begin{array}{l}\text { Burnup, MWd/KgM } \\
\text { (Measured) }\end{array}$ \\
\hline 106-NBD095-MM & $\begin{array}{l}\mathrm{MCC}{ }^{129} \mathrm{I} \text { in Fuel and on Cladding } \\
\mathrm{ID}, \mathrm{MCC}{ }^{135} \mathrm{Cs} \text { and }{ }^{137} \mathrm{Cs} \text { on } \\
\text { Cladding } \mathrm{D} \text {; Hydrogen in Cladding }\end{array}$ & 2156.9 & 45.6 \\
\hline 106-NBD095-NN & $\begin{array}{l}\text { MCC Transverse Metallography- } \\
\text { Ceramography }\end{array}$ & 2134.8 & 45.1 \\
\hline 106-NBD095-OO & $\begin{array}{l}\text { MCC Longitudinal Metallography- } \\
\text { Ceramography }\end{array}$ & 2175.3 & 46.1 \\
\hline 106-NBD095-PP & $\mathrm{MCC}{ }^{14} \mathrm{C}$ in Fuel and Cladding & 2121.8 & 44.8 \\
\hline 106-NBD095-QQ & MCC Acid Etch Assay & 2097.2 & 44.3 \\
\hline 106-NBD095-RR & MCC Acid Etch Assay & 2155.5 & 45.6 \\
\hline 106-NBD095-SS & MCC Acid Etch Assay & 2187.6 & 46.3 \\
\hline 106-NBD095-TT & MCC Acid Etch Assay & 2177.7 & 46.1 \\
\hline 106-NBD095-UU & MCC Acid Etch Assay & 2113.4 & 44.6 \\
\hline 106-NBD095-VV & MCC Spare Material & 2132.6 & 45.1 \\
\hline 106-NBD095-WW & $\mathrm{MCC}{ }^{3} \mathrm{H}$ in Cladding & 2117.1 & 44.7 \\
\hline 106-NBD095-XX & $\begin{array}{l}\text { MCC }{ }^{129} \mathrm{I} \text { in Fuel and on Cladding } \\
\mathrm{D} \text {, MCC }{ }^{135} \mathrm{Cs} \text { and }{ }^{137} \mathrm{Cs} \text { on } \\
\text { Cladding } \mathrm{D} \text {; Hydrogen in Cladding }\end{array}$ & 2108.7 & 44.5 \\
\hline 106-NBD095-YY & $\begin{array}{l}\text { MCC Transverse Metallography- } \\
\text { Ceramography }\end{array}$ & 2111.9 & 44.6 \\
\hline 106-NBD095-ZZ & MCC Spare Material & 1900.8 & 39.8 \\
\hline 106-NBD095-AAA & MCC GGBI Sample & 1562.4 & 32.1 \\
\hline 106-NBD095-BBB & $\mathrm{MCC}^{3} \mathrm{H}$ in Cladding & 1501.1 & 30.7 \\
\hline 106-NBD095-CCC & $\begin{array}{l}\text { MCC }{ }^{129} \mathrm{I} \text { in Fuel and on Cladding } \\
\mathrm{ID}, \mathrm{MCC}{ }^{135} \mathrm{Cs} \text { and }{ }^{137} \mathrm{Cs} \text { on } \\
\text { Cladding } \mathrm{ID} \text {; Hydrogen in Cladding }\end{array}$ & 1432.2 & 29.1 \\
\hline 106-NBD095-DDD & $\begin{array}{l}\text { MCC Transverse Metallography- } \\
\text { Ceramography }\end{array}$ & 1338.8 & 27.0 \\
\hline
\end{tabular}


Table A.3. (contd)

\begin{tabular}{|c|c|c|c|c|}
\hline \multicolumn{2}{|c|}{$\begin{array}{l}\text { Section } \\
\text { Identification }\end{array}$} & Section Assignment & $\begin{array}{l}\text { Original Activity } \\
\text { Counts/s }\end{array}$ & $\begin{array}{l}\text { Burnup, MWd/KgM } \\
\text { (Measured) }\end{array}$ \\
\hline \multicolumn{2}{|c|}{ 106-NBD095-EEE } & $\mathrm{MCC}{ }^{14} \mathrm{C}$ in Fuel and Cladding & 1269.2 & 25.4 \\
\hline \multicolumn{2}{|c|}{ 106-NBD095-FFF } & MCC Spare Material & 802.7 & 14.7 \\
\hline \multicolumn{5}{|c|}{$\begin{array}{l}\text { (a) Samples C and D and Samples X and Y from Rod NBD095 were combined to provide a } \\
\text { blended fuel sample for SSMS and burnup analyses. }\end{array}$} \\
\hline Note: & \multicolumn{4}{|c|}{$\begin{array}{l}\text { To determine the burnups in this table, the two known burnups from Sections } \mathrm{C} / \mathrm{D} \text { and } \mathrm{X} / \mathrm{Y} \\
\text { were plotted against the average Cesium-137 activity found over sections by the program } \\
\text { AREA (code custodian NJ Wildung). A linear equation was found that related the burnup } \\
\text { as a function of Cesium- } 137 \text { activity so that the burnup over any section of the rod could be } \\
\text { estimated by knowing the Cesium- } 137 \text { activity over the section. The equation created and } \\
\text { used was } \mathrm{BU}=0.02284 \mathrm{~A}-3.620 \text { where } \mathrm{BU} \text { is burnup in } \mathrm{MWd} / \mathrm{KgM} \text { and } \mathrm{A} \text { is Cesium-137 } \\
\text { activity in counts/s. }\end{array}$} \\
\hline
\end{tabular}


Table A.4. Cesium-137 Activities and Estimated Burnups for Rod NBD131

\begin{tabular}{|c|c|c|c|}
\hline Section Identification & Section Assignment & $\begin{array}{c}\text { Original Activity } \\
\text { Counts/s }\end{array}$ & $\begin{array}{l}\text { Burnup, MWd/KgM } \\
\text { (Measured) }\end{array}$ \\
\hline 106-NBD131-A & MCC Spare Material & 429.2 & 5.7 \\
\hline 106-NBD131-B & $\begin{array}{l}\text { MCC Transverse Metallography- } \\
\text { Ceramography }\end{array}$ & 1351.1 & 25.8 \\
\hline 106-NBD131-B(lost) & Lost Sample & 1332.5 & 25.4 \\
\hline 106-NBD131-C & $\begin{array}{l}\text { MCC }{ }^{129} \mathrm{I} \text { on Cladding ID, MCC } \\
{ }^{135} \mathrm{Cs} \text { and }{ }^{137} \mathrm{Cs} \text { on Cladding ID }\end{array}$ & 1533.7 & 29.8 \\
\hline 106-NBD131-D & MCC ${ }^{14} \mathrm{C}$ in Fuel and Cladding & 1689.3 & 33.2 \\
\hline 106-NBD131-E & MCC Spare and Archive Material & 1932.6 & 38.6 \\
\hline 106-NBD131-F & $\begin{array}{l}\text { MCC }{ }^{129} \mathrm{I} \text { in Fuel and on } \\
\text { Cladding ID, MCC }{ }^{135} \mathrm{Cs} \text { and } \\
{ }^{137} \mathrm{Cs} \text { on Cladding ID }\end{array}$ & 2147.1 & 43.2 \\
\hline 106-NBD131-G & MCC Spare Material & 2283.3 & 46.2 \\
\hline 106-NBD131-H & $\begin{array}{l}\text { MCC Longitudinal } \\
\text { Metallography-Ceramography }\end{array}$ & 2386.5 & 48.5 \\
\hline 106-NBD131-I & $\begin{array}{l}\text { MCC Transverse Metallography- } \\
\text { Ceramography }\end{array}$ & 2364.4 & 48.0 \\
\hline 106-NBD131-J & $\begin{array}{l}\text { MCC }{ }^{129} \mathrm{I} \text { on Cladding ID, MCC } \\
{ }^{135} \mathrm{Cs} \text { and }{ }^{137} \mathrm{Cs} \text { on Cladding ID }\end{array}$ & 2323.1 & 47.1 \\
\hline 106-NBD131-K & $\mathrm{MCC}{ }^{14} \mathrm{C}$ in Fuel and Cladding & 2447.6 & 49.8 \\
\hline 106-NBD131-L & MCC Spare and Archive Material & 2384.0 & 48.4 \\
\hline 106-NBD131-M & $\begin{array}{l}\text { MCC Transverse Metallography- } \\
\text { Ceramography }\end{array}$ & 2358.6 & 47.9 \\
\hline 106-NBD131-N & $\begin{array}{l}\text { MCC }{ }^{129} \mathrm{I} \text { on Cladding ID, MCC } \\
{ }^{135} \mathrm{Cs} \text { and }{ }^{137} \mathrm{Cs} \text { on Cladding ID }\end{array}$ & 2406.5 & 48.9 \\
\hline 106-NBD131-O & MCC Spare Material & 2368.6 & 48.1 \\
\hline 106-NBD131-P & $\begin{array}{l}\text { MCC Transverse Metallography- } \\
\text { Ceramography }\end{array}$ & 2376.7 & 48.3 \\
\hline 106-NBD131-Q & $\begin{array}{l}\text { MCC Burnup, Isotopes, and } \\
\text { Radionuclides }\end{array}$ & 2404.6 & $48.9(49.65)$ \\
\hline
\end{tabular}


Table A.4. (contd)

\begin{tabular}{|c|c|c|c|}
\hline Section Identification & Section Assignment & $\begin{array}{c}\text { Original Activity } \\
\text { Counts/s }\end{array}$ & $\begin{array}{c}\text { Burnup, MWd/KgM } \\
\text { (Measured) }\end{array}$ \\
\hline 106-NBD131-R & $\begin{array}{l}\mathrm{MCC}{ }^{129} \mathrm{I} \text { in Fuel and on } \\
\text { Cladding ID, MCC }{ }^{135} \mathrm{Cs} \text { and } \\
{ }^{137} \mathrm{Cs} \text { on Cladding ID }\end{array}$ & 2374.1 & 48.2 \\
\hline 106-NBD131-S & $\mathrm{MCC}{ }^{14} \mathrm{C}$ in Fuel and Cladding & 2367.0 & 48.1 \\
\hline 106-NBD131-T & MCC Spare and Archive Material & 2352.7 & 47.7 \\
\hline 106-NBD131-U & $\begin{array}{l}\text { MCC Longitudinal } \\
\text { Metallography-Ceramography }\end{array}$ & 2338.7 & 47.4 \\
\hline 106-NBD131-V & $\begin{array}{l}\text { MCC Transverse Metallography- } \\
\text { Ceramography }\end{array}$ & 2459.7 & 50.1 \\
\hline 106-NBD131-W & $\begin{array}{l}\text { MCC }{ }^{129} \mathrm{I} \text { in Fuel and on } \\
\text { Cladding ID, MCC }{ }^{135} \mathrm{Cs} \text { and } \\
{ }^{137} \mathrm{Cs} \text { on Cladding ID }\end{array}$ & 2393.9 & 48.6 \\
\hline 106-NBD131-X & $\mathrm{MCC}{ }^{14} \mathrm{C}$ in Fuel and Cladding & 2252.1 & 45.5 . \\
\hline 106-NBD131-Y & MCC Spare Material & 2340.8 & 47.5 \\
\hline 106-NBD131-Z & $\begin{array}{l}\text { MCC }{ }^{129} \mathrm{I} \text { on Cladding ID, MCC } \\
{ }^{135} \mathrm{Cs} \text { and }{ }^{137} \mathrm{Cs} \text { on Cladding ID }\end{array}$ & 2292.5 & 46.4 \\
\hline 106-NBD131-AA & MCC Spare Material & 2104.9 & 42.3 \\
\hline 106-NBD13̣1-BB & $\begin{array}{l}\text { MCC Transverse Metallography- } \\
\text { Ceramography }\end{array}$ & 1699.6 & 33.5 \\
\hline 106-NBD131-CC & $\begin{array}{l}\text { MCC Burnup, Isotopes, and } \\
\text { Radionuclides }\end{array}$ & 1544.4 & $30.3(31.28)$ \\
\hline 106-NBD131-DD & $\begin{array}{l}\text { MCC }{ }^{129} \mathrm{I} \text { in Fuel and on } \\
\text { Cladding ID, MCC }{ }^{135} \mathrm{Cs} \text { and } \\
{ }^{137} \mathrm{Cs} \text { on Cladding ID }\end{array}$ & 1505.8 & 29.2 \\
\hline 106-NBD131-EE & $\mathrm{MCC}{ }^{14} \mathrm{C}$ in Fuel and Cladding & 1342.6 & 25.7 \\
\hline 106-NBD131-FF & MCC Spare Material & 842.9 & 14.7 \\
\hline \multicolumn{4}{|c|}{$\begin{array}{l}\text { Note: The burnups were calculated using the burnup equation } B U=0.02187 \mathrm{~A}-3.71 \text {. The } \\
\text { burnup equation was formulated by plotting the known burnups of Sections } \mathrm{Q} \text { and } \mathrm{CC} \\
\text { against the measured Cesium-137 activity over the two sections which were found } \\
\text { graphically. Then the linear burnup equation was found that related the burnup as a } \\
\text { function of Cesium-137 activity so that the burnup over any section of the rod could be } \\
\text { estimated by knowing the Cesium-137 activity over the section. }\end{array}$} \\
\hline
\end{tabular}




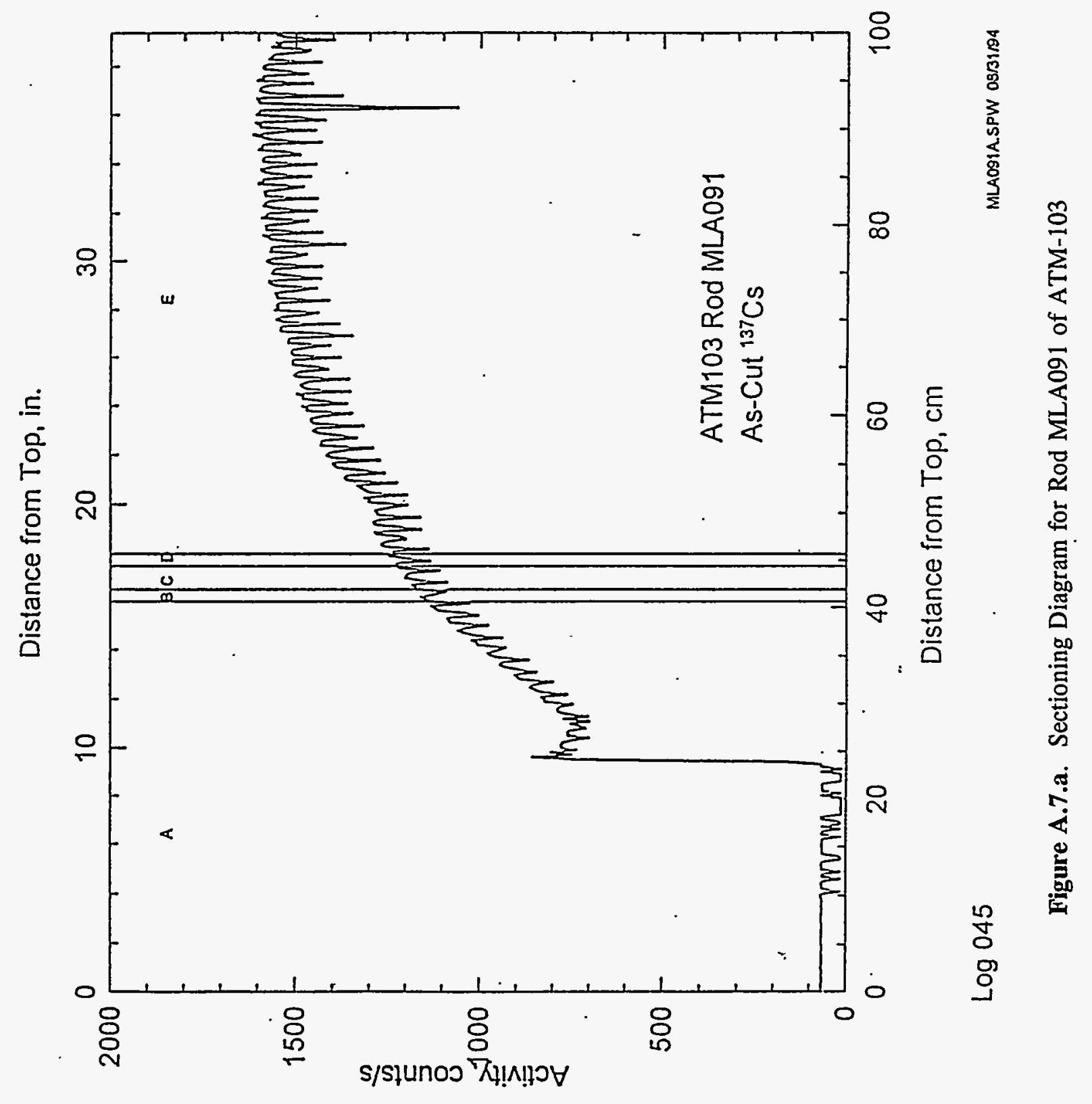

A. 18 


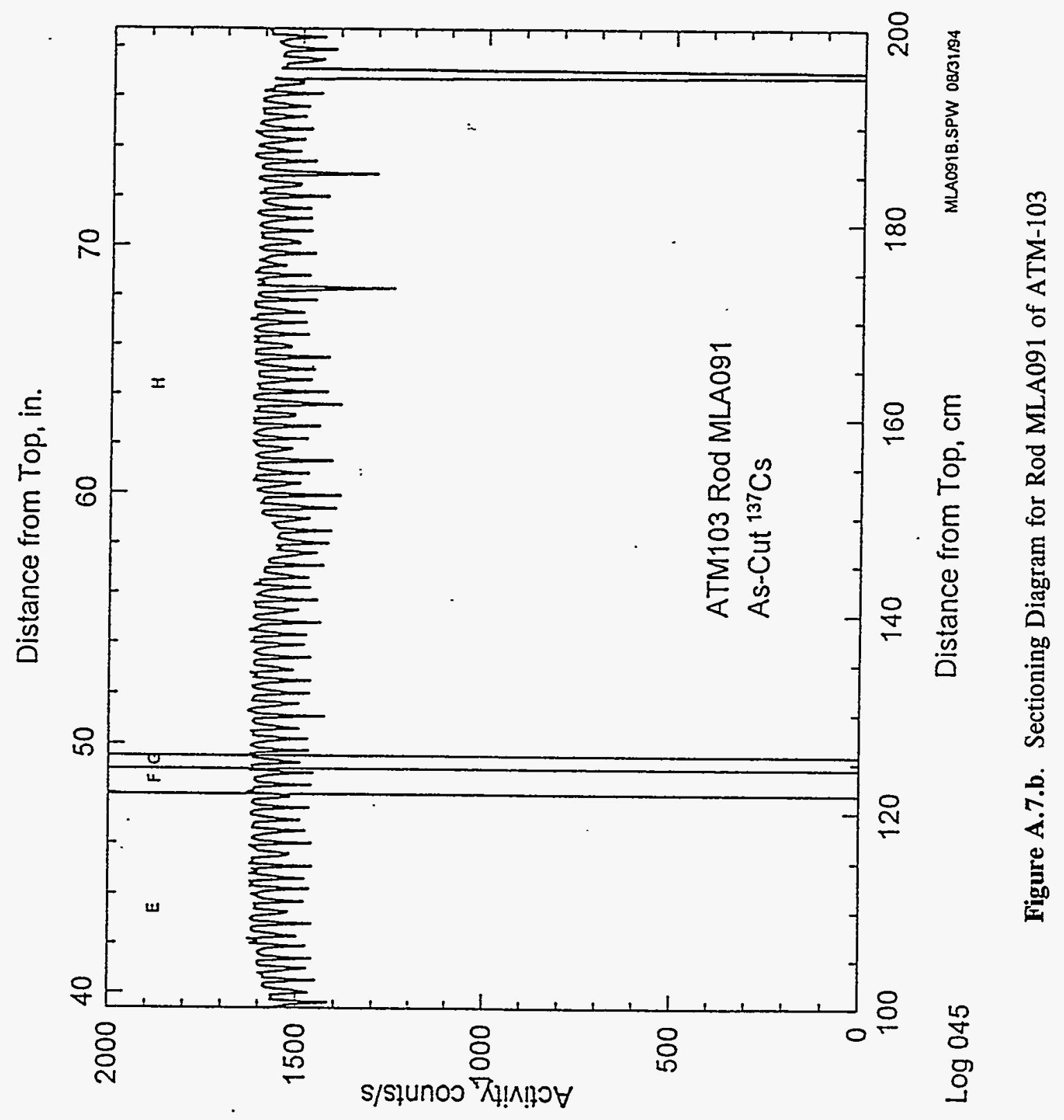

A. 19 


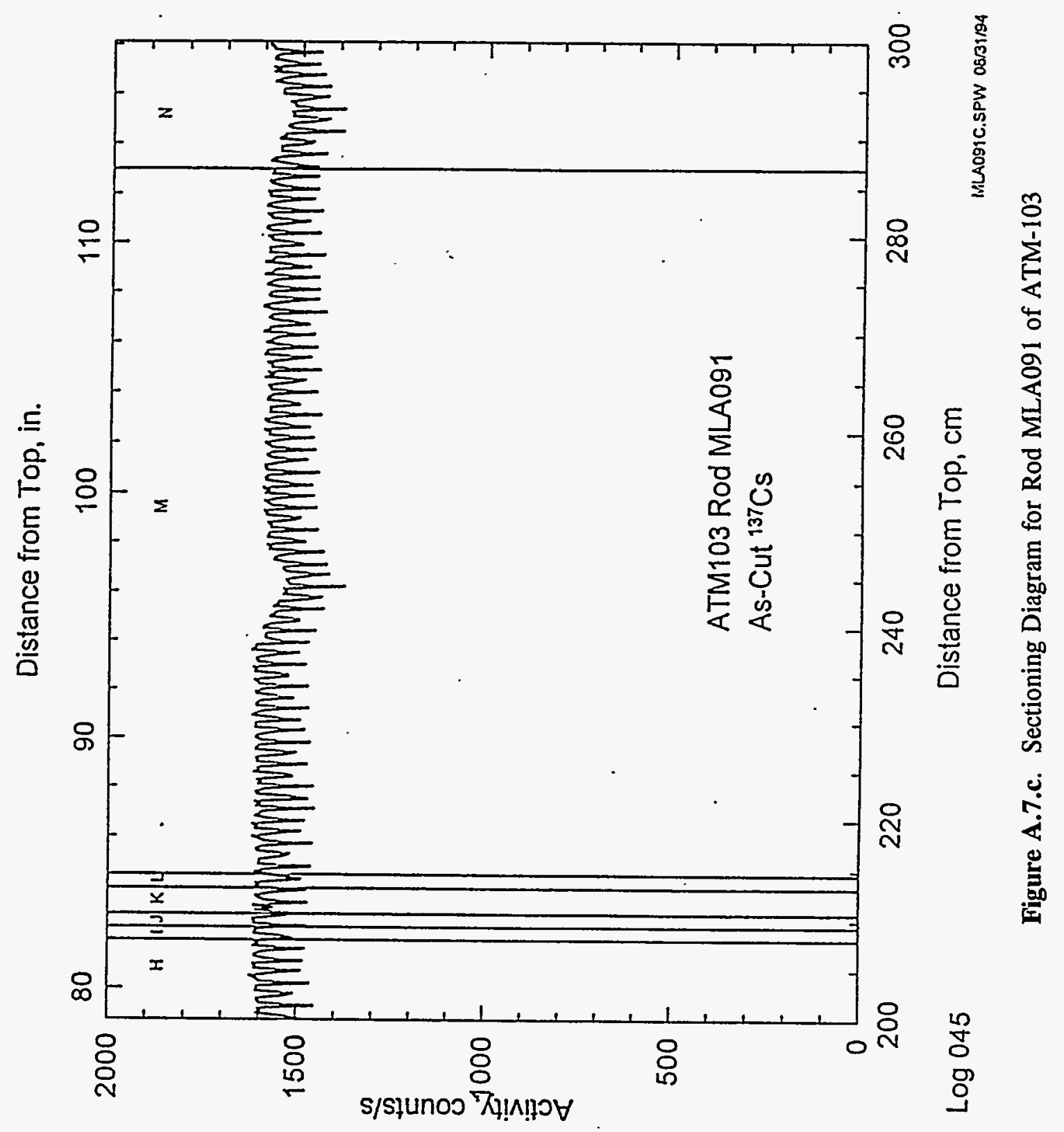

A. 20 


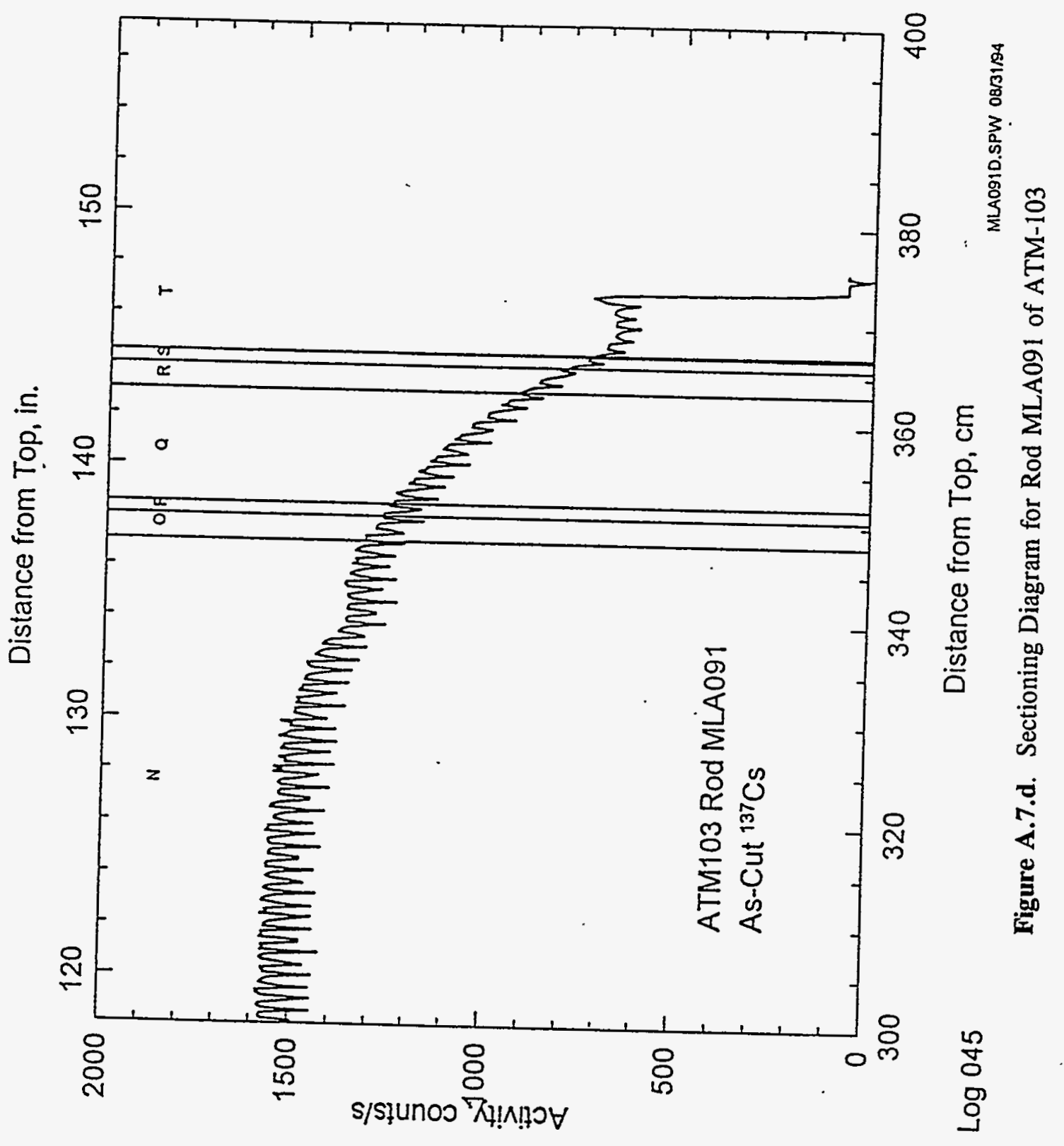

A. 21 


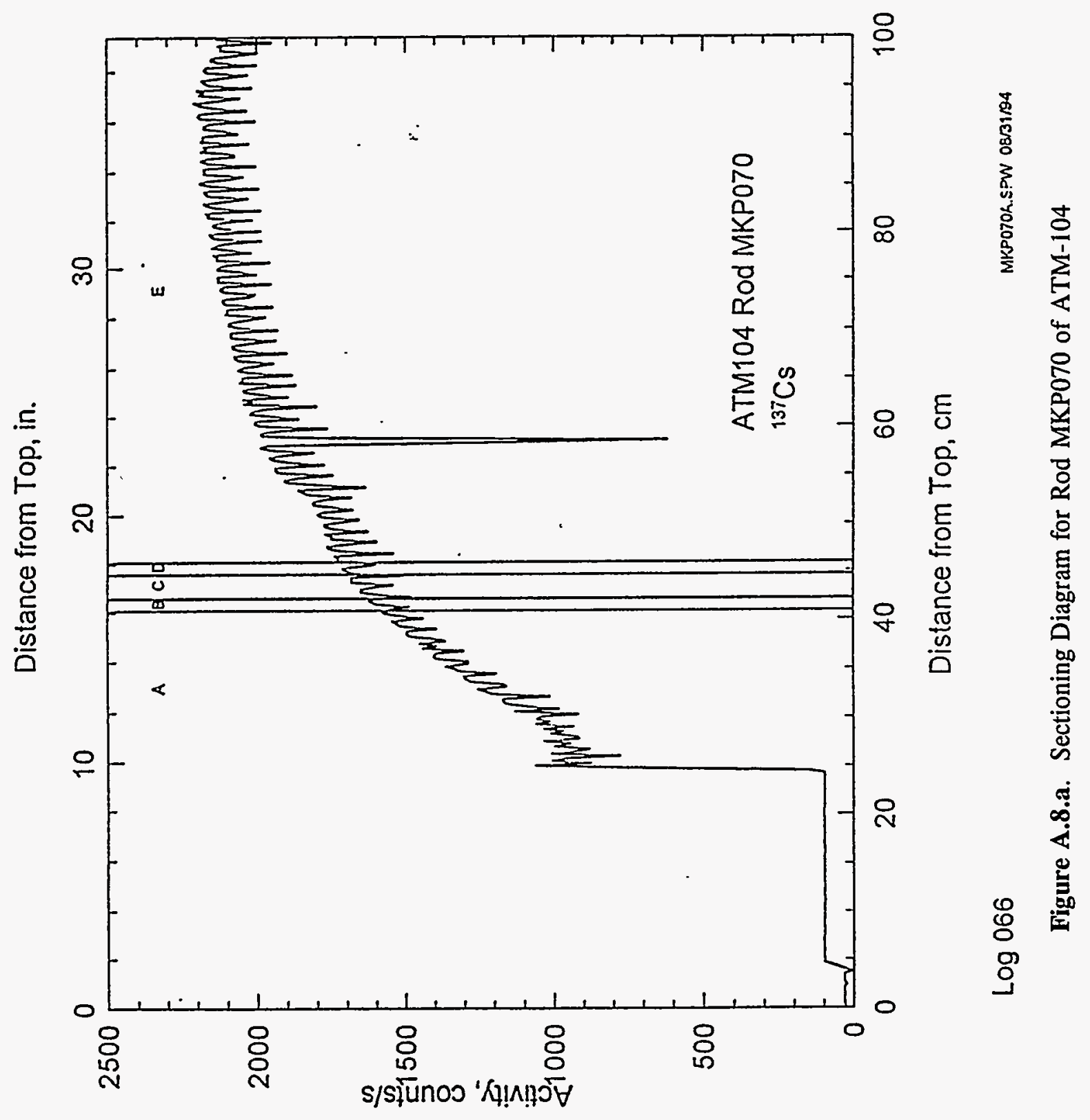




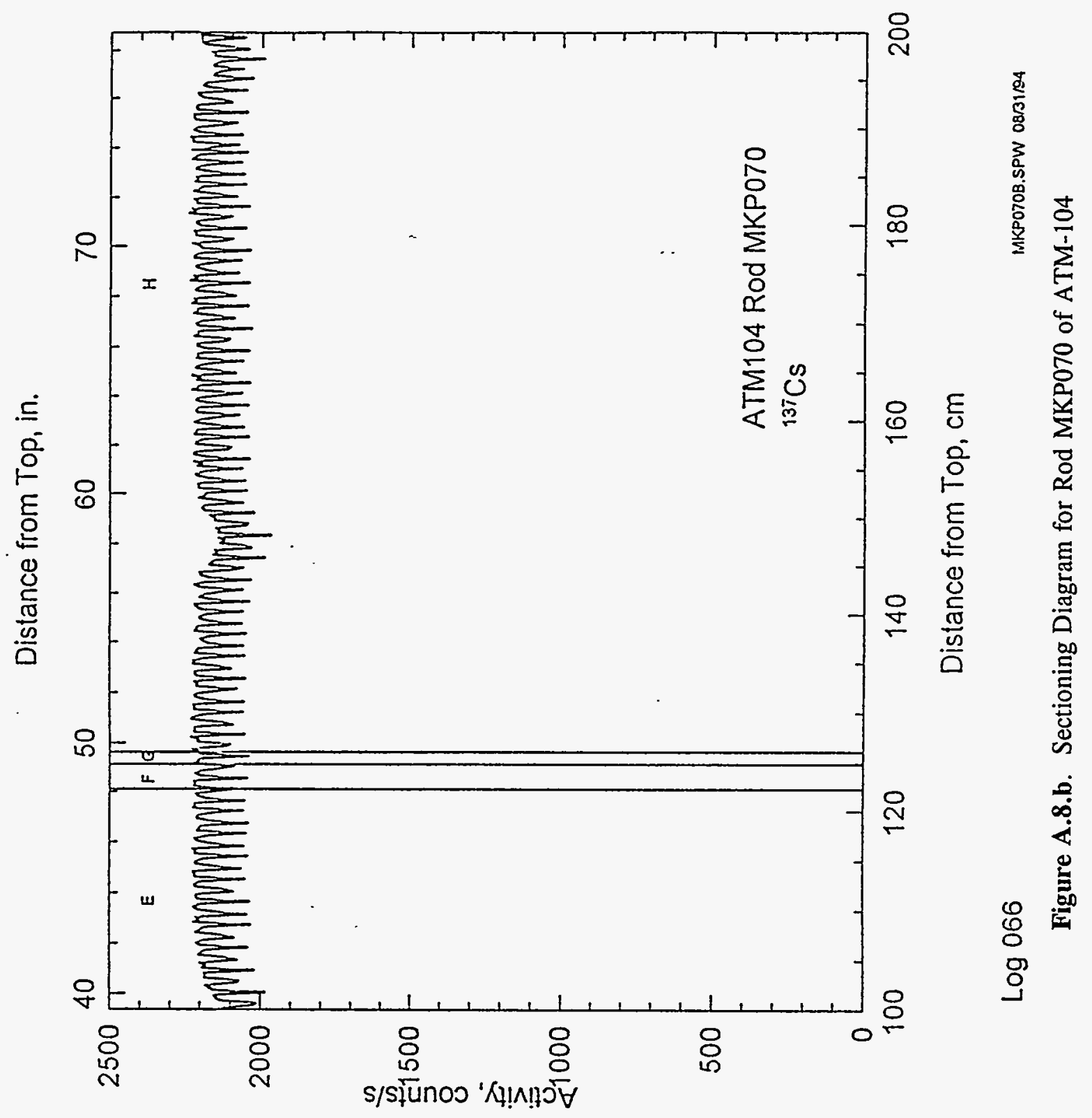




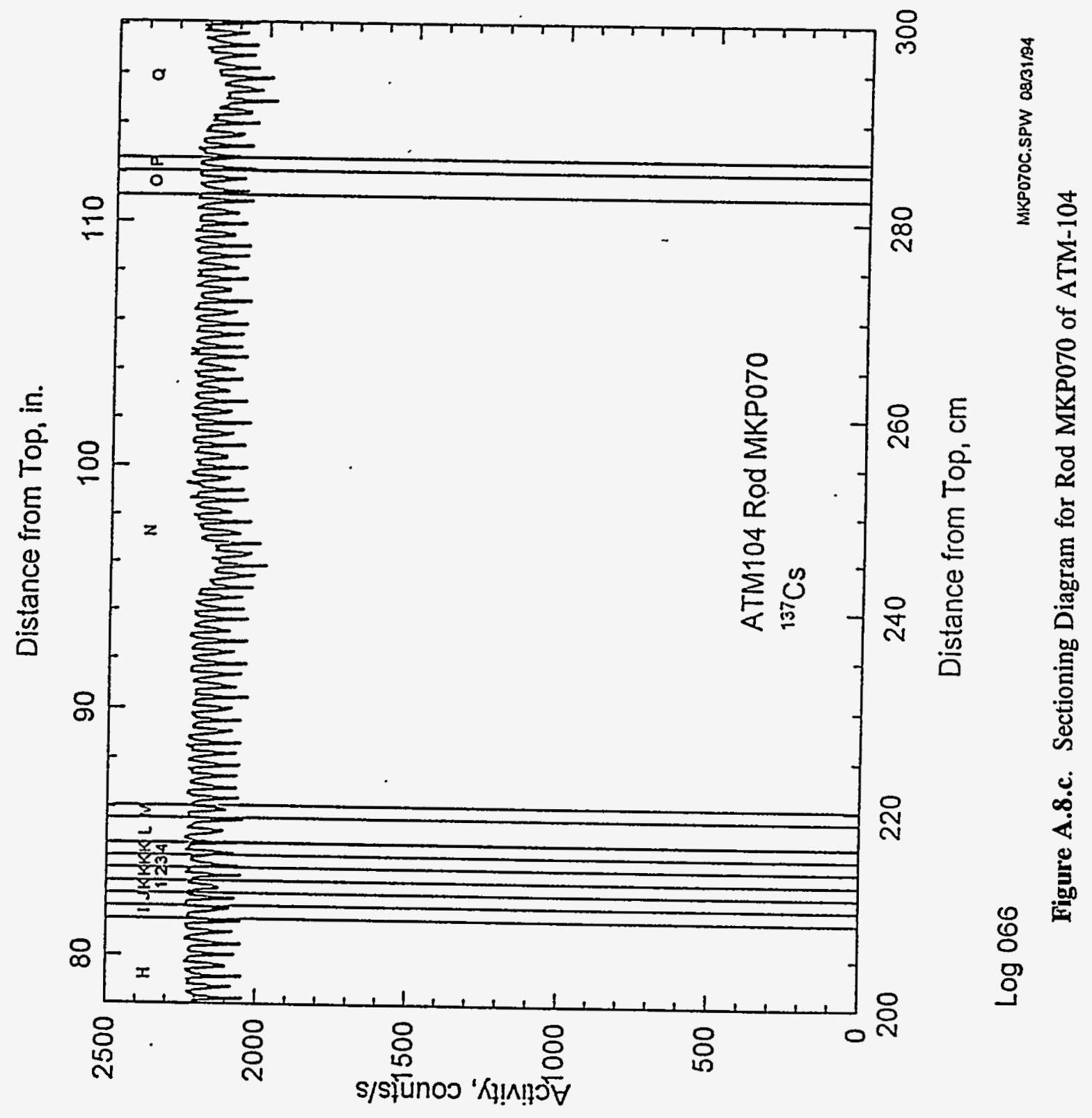

A.24 


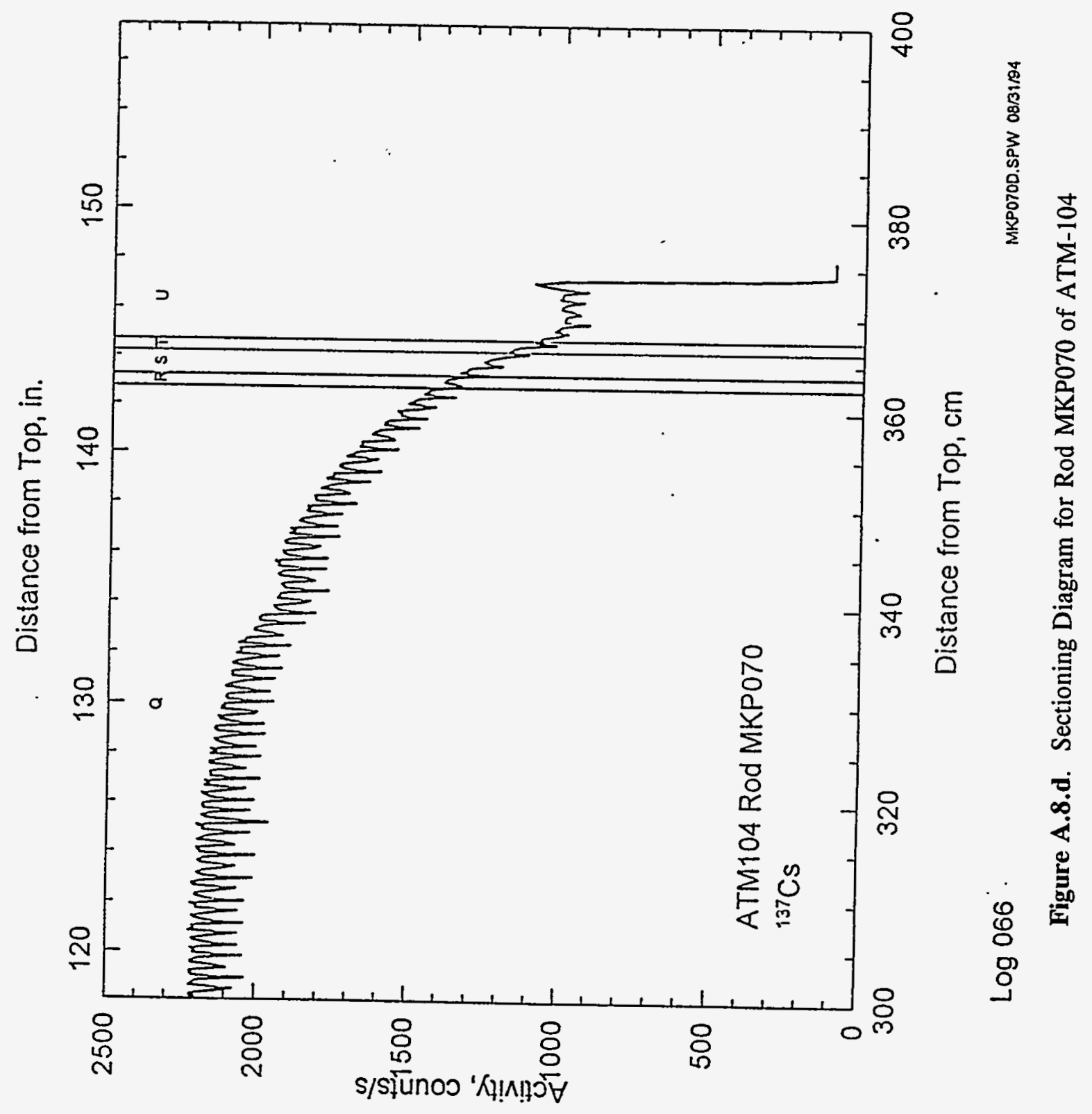




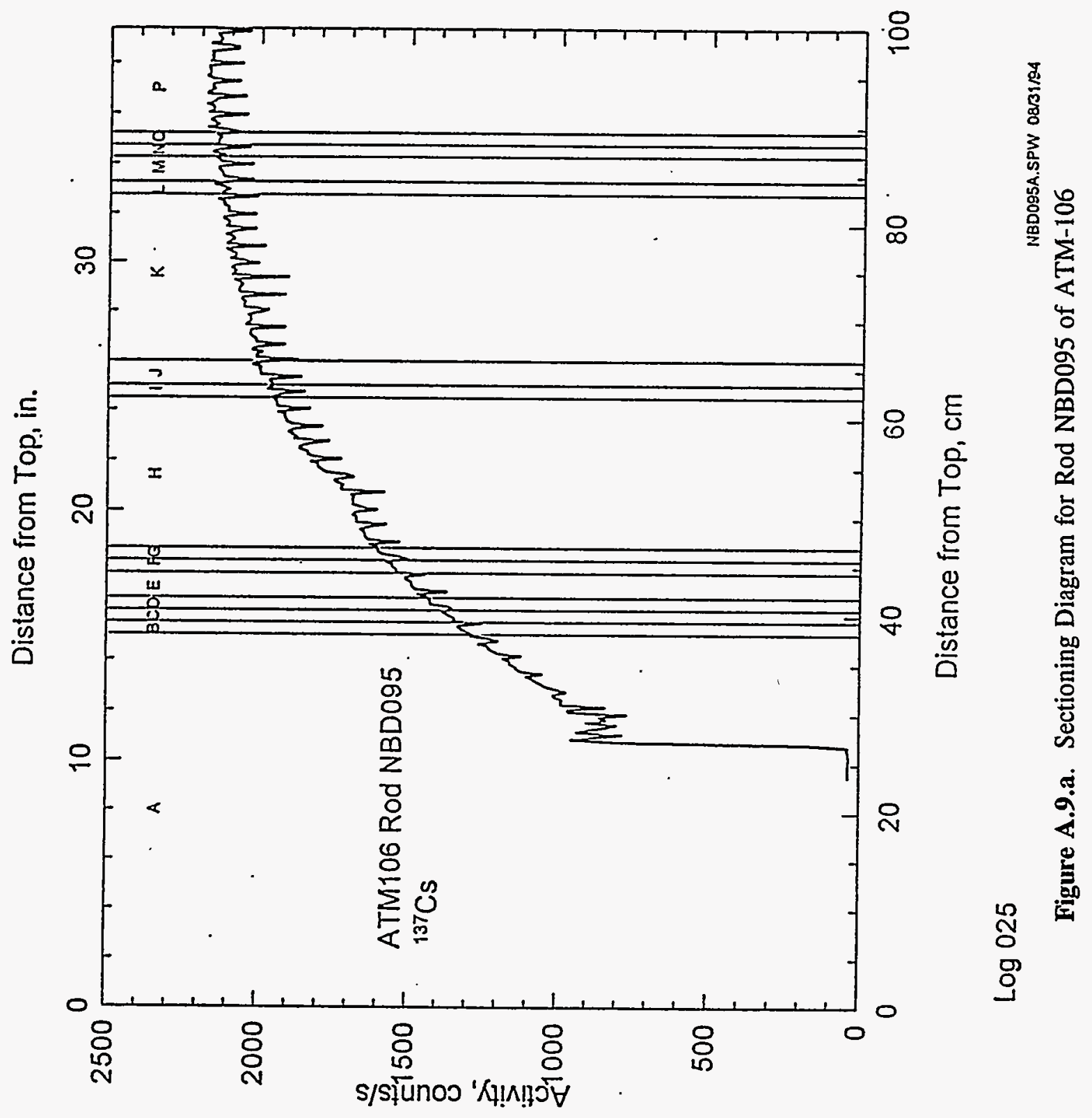

A. 26 


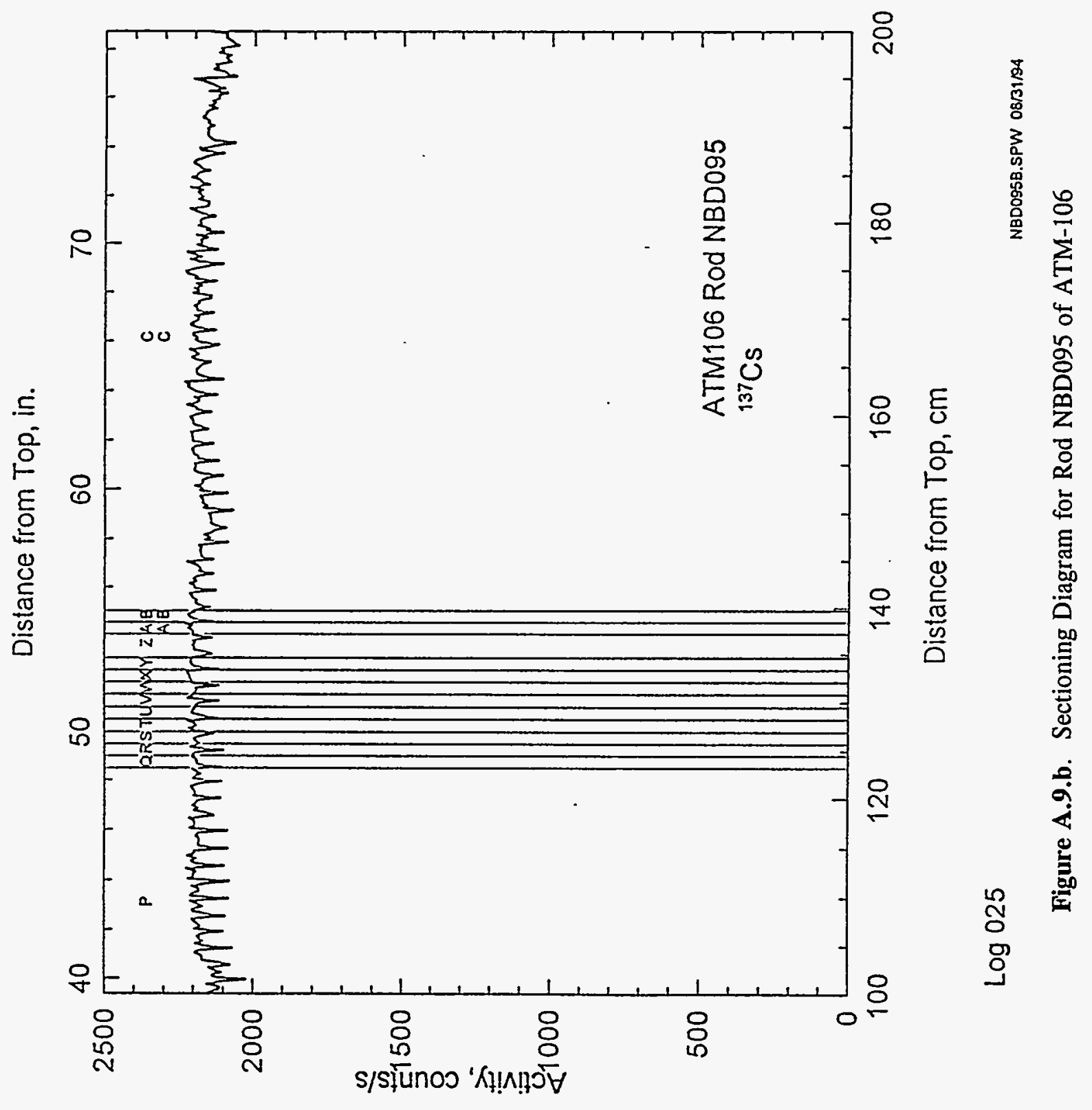




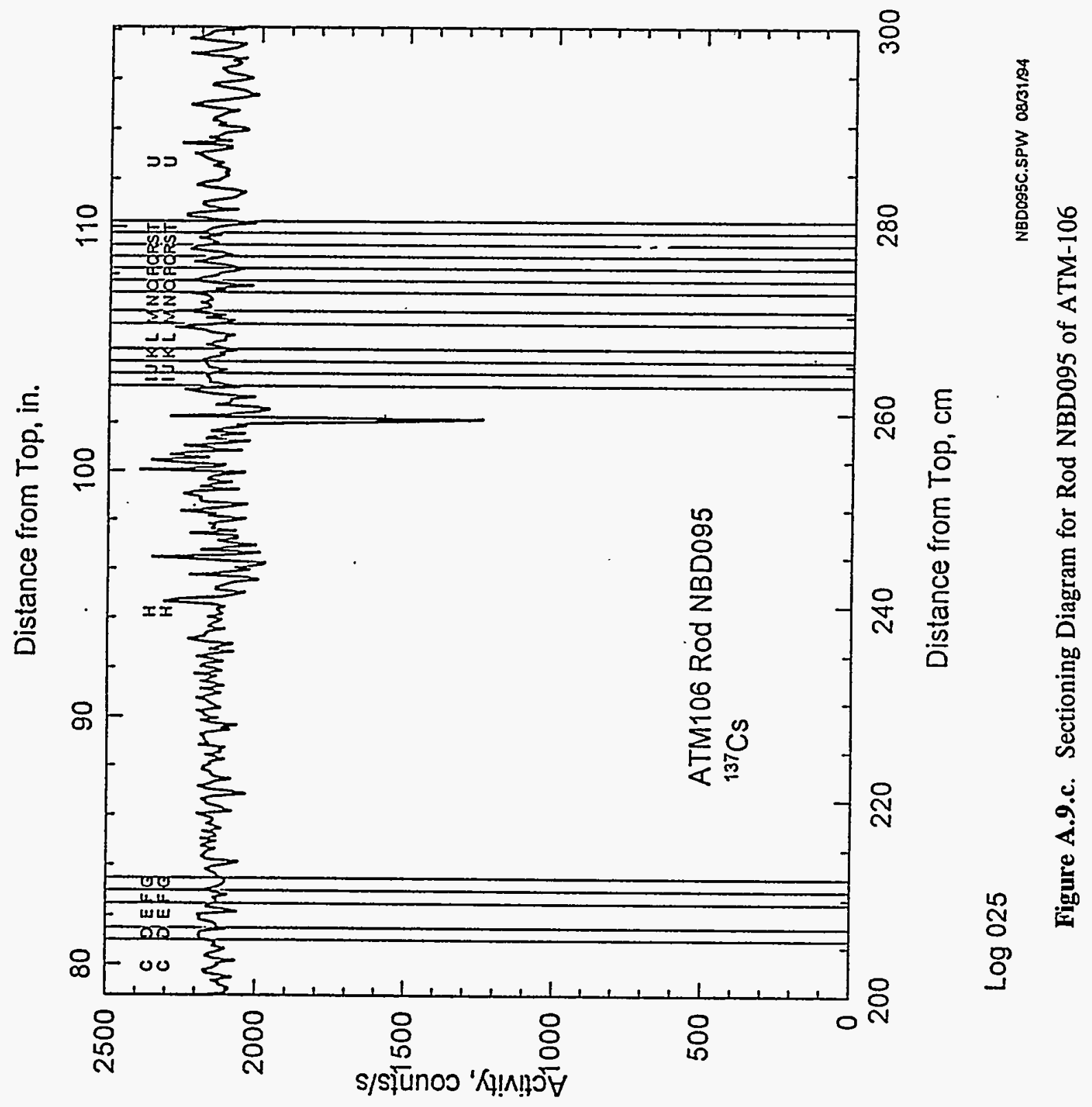




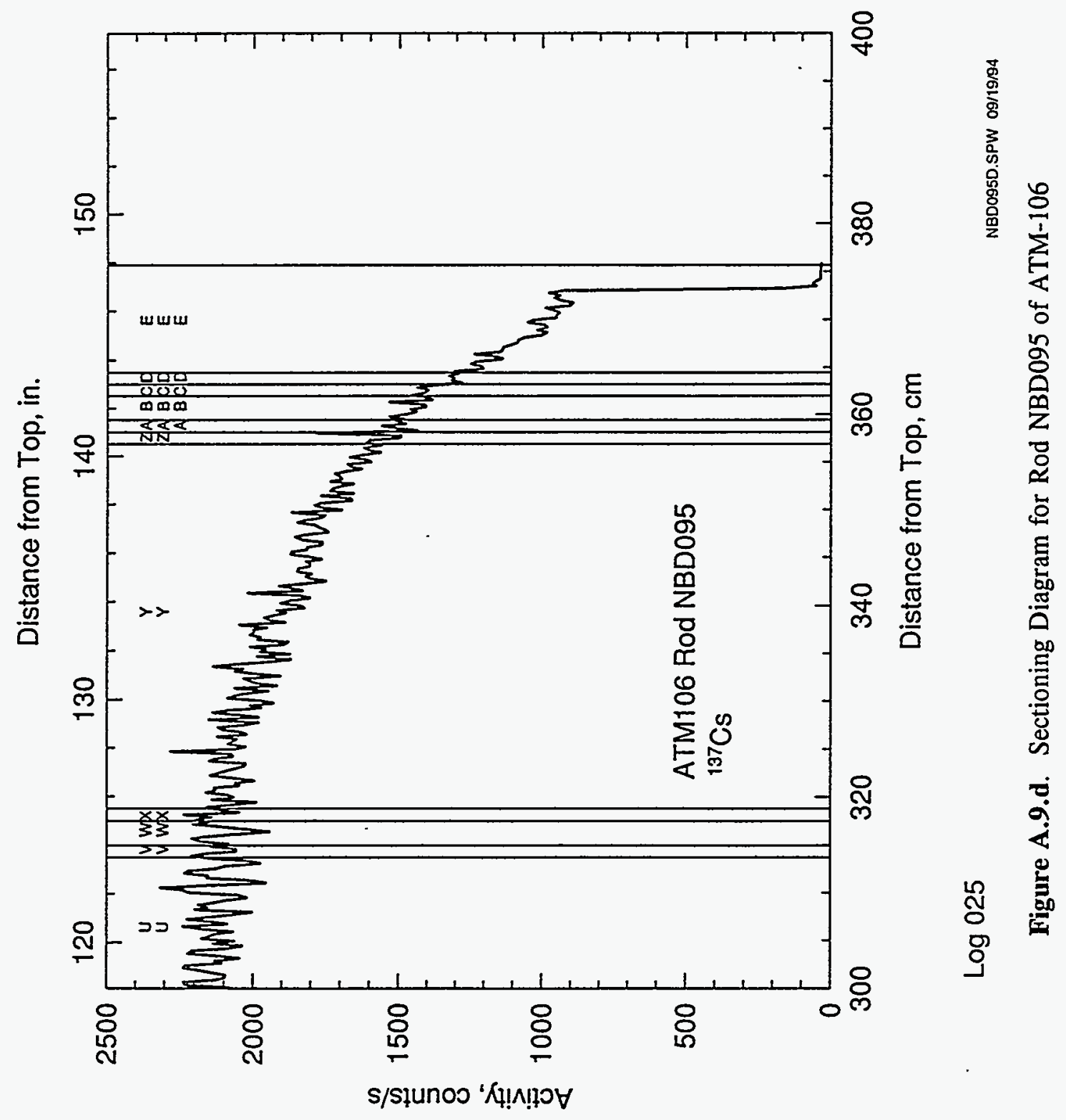




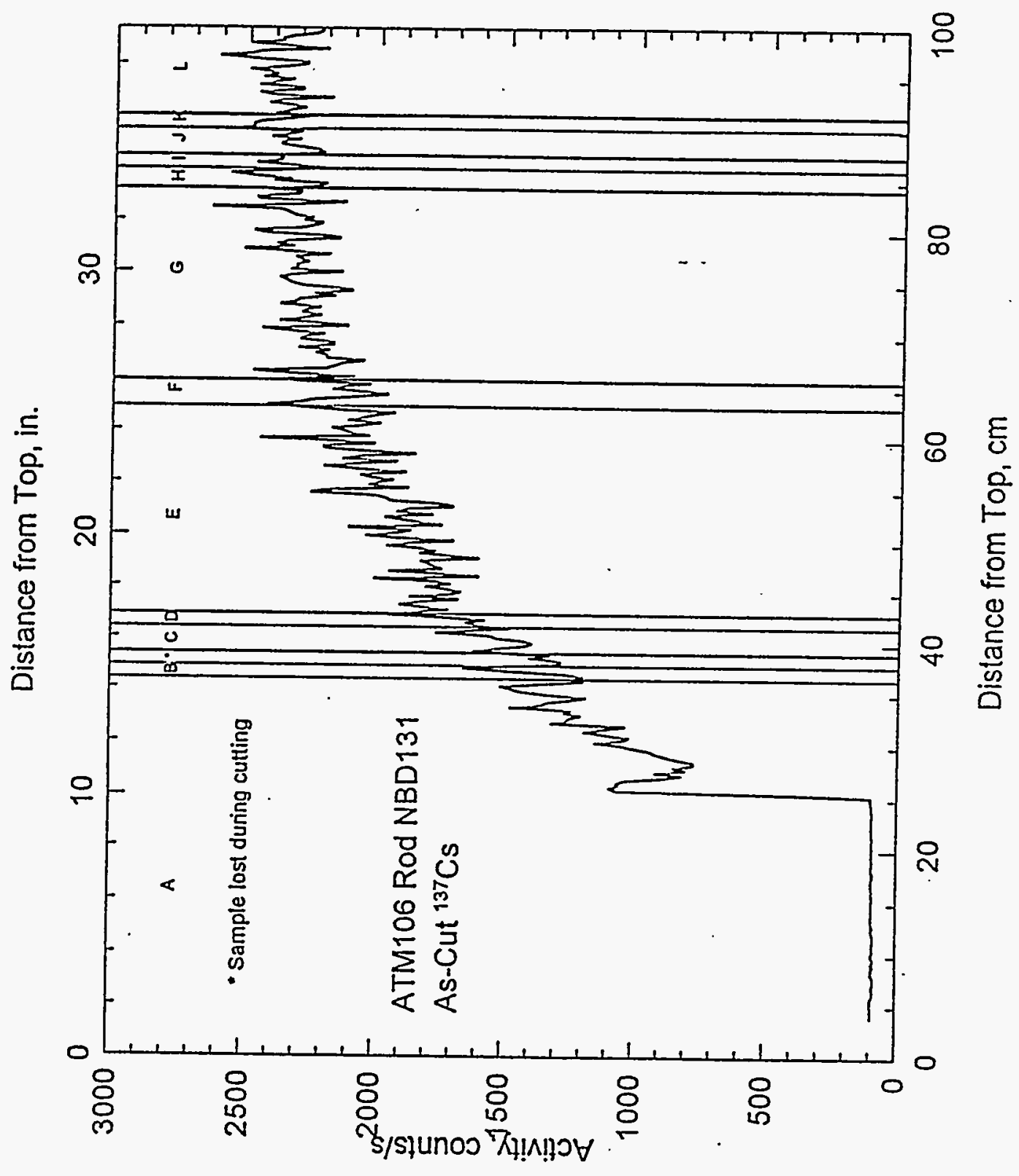

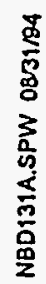



مَ 


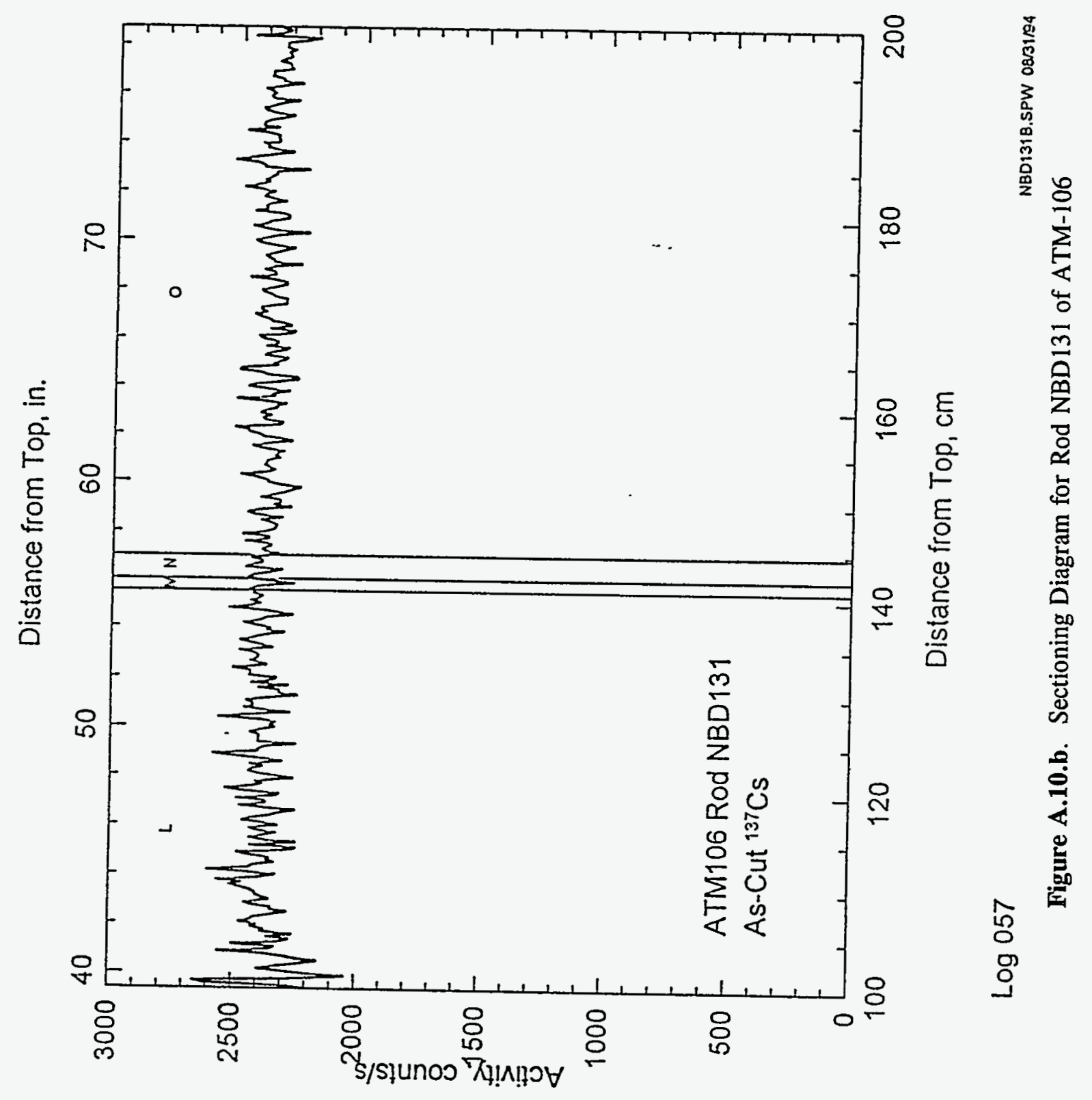

A. 31 


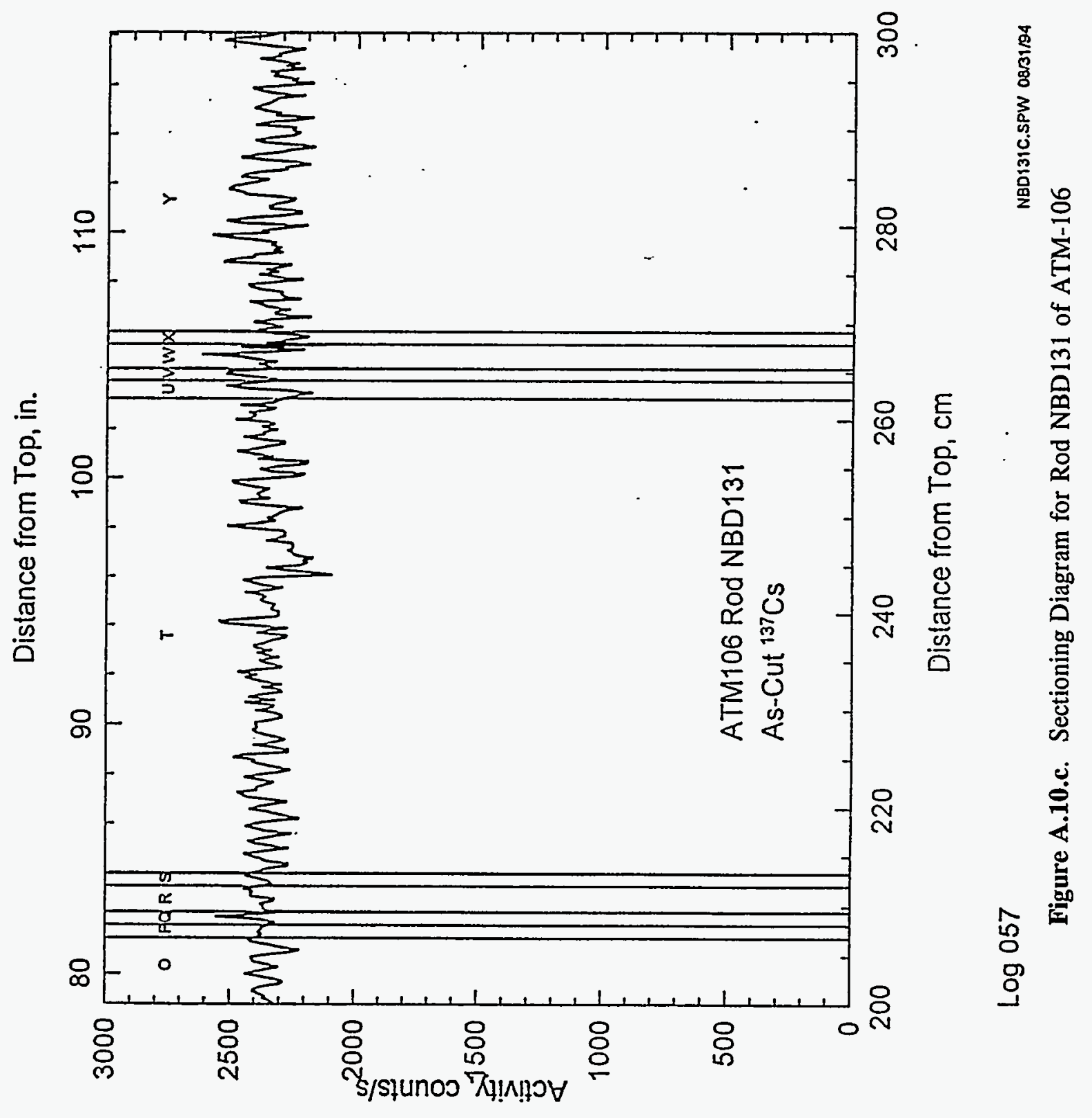

A. 32 


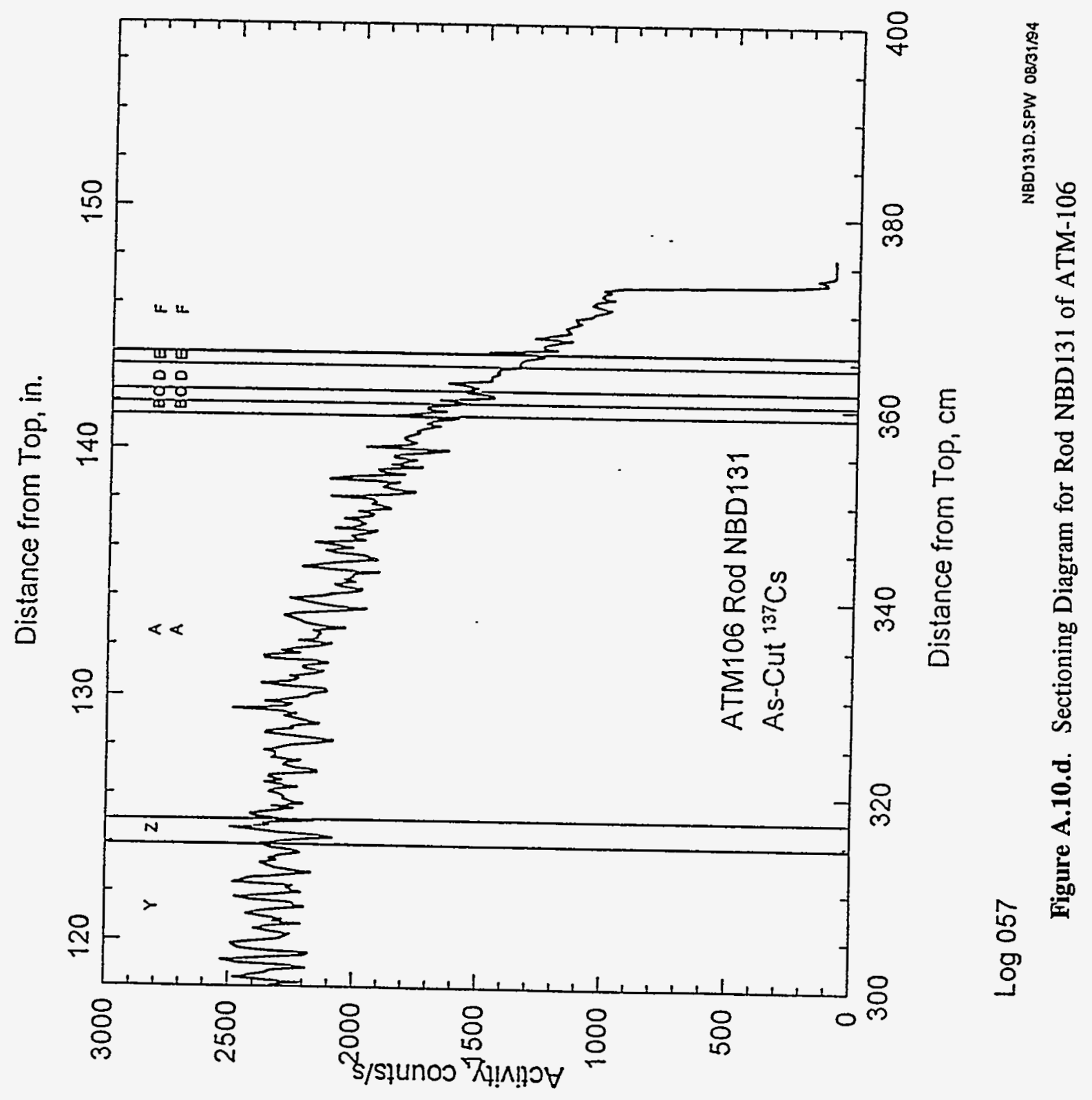

A. 33 


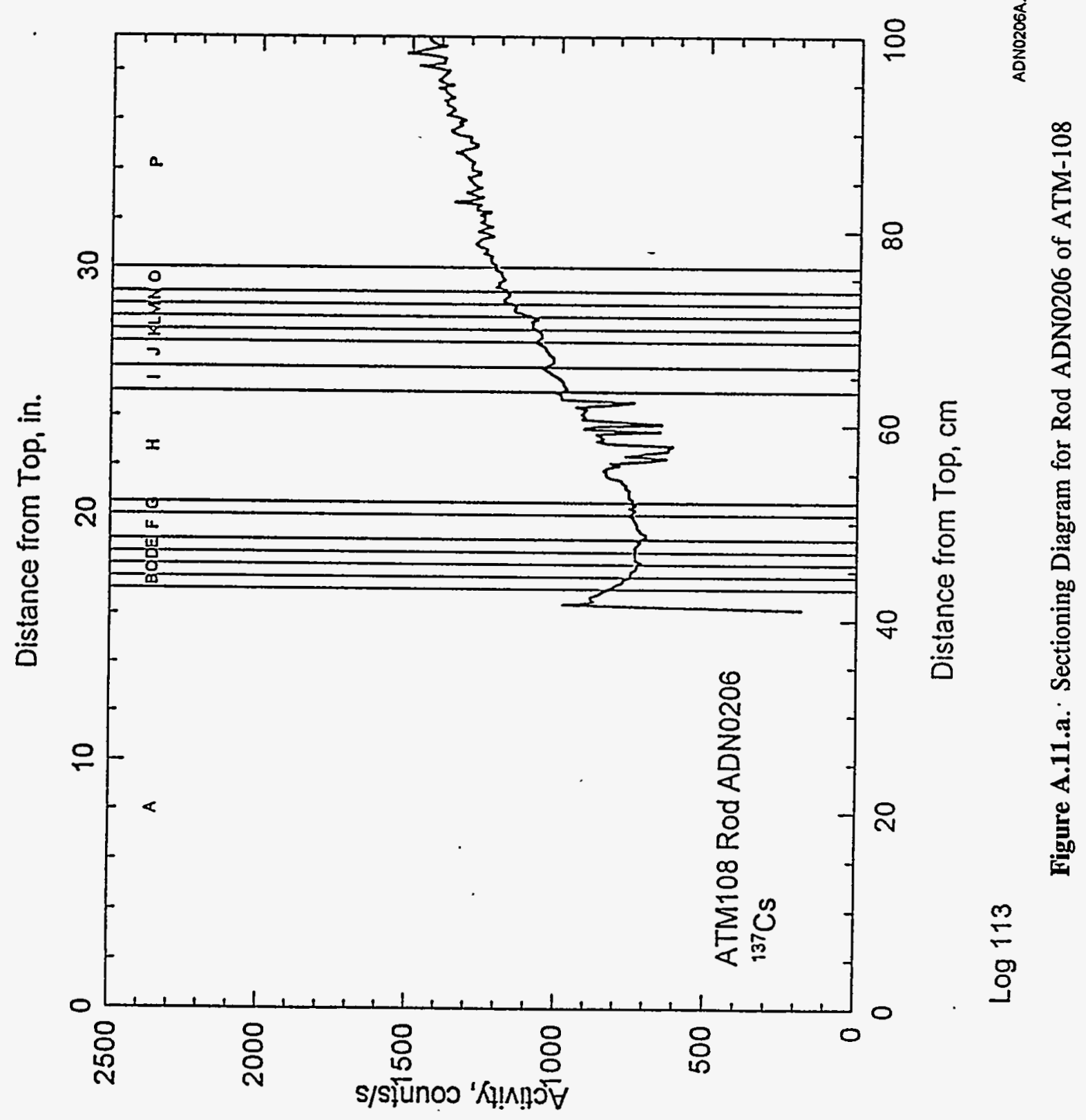




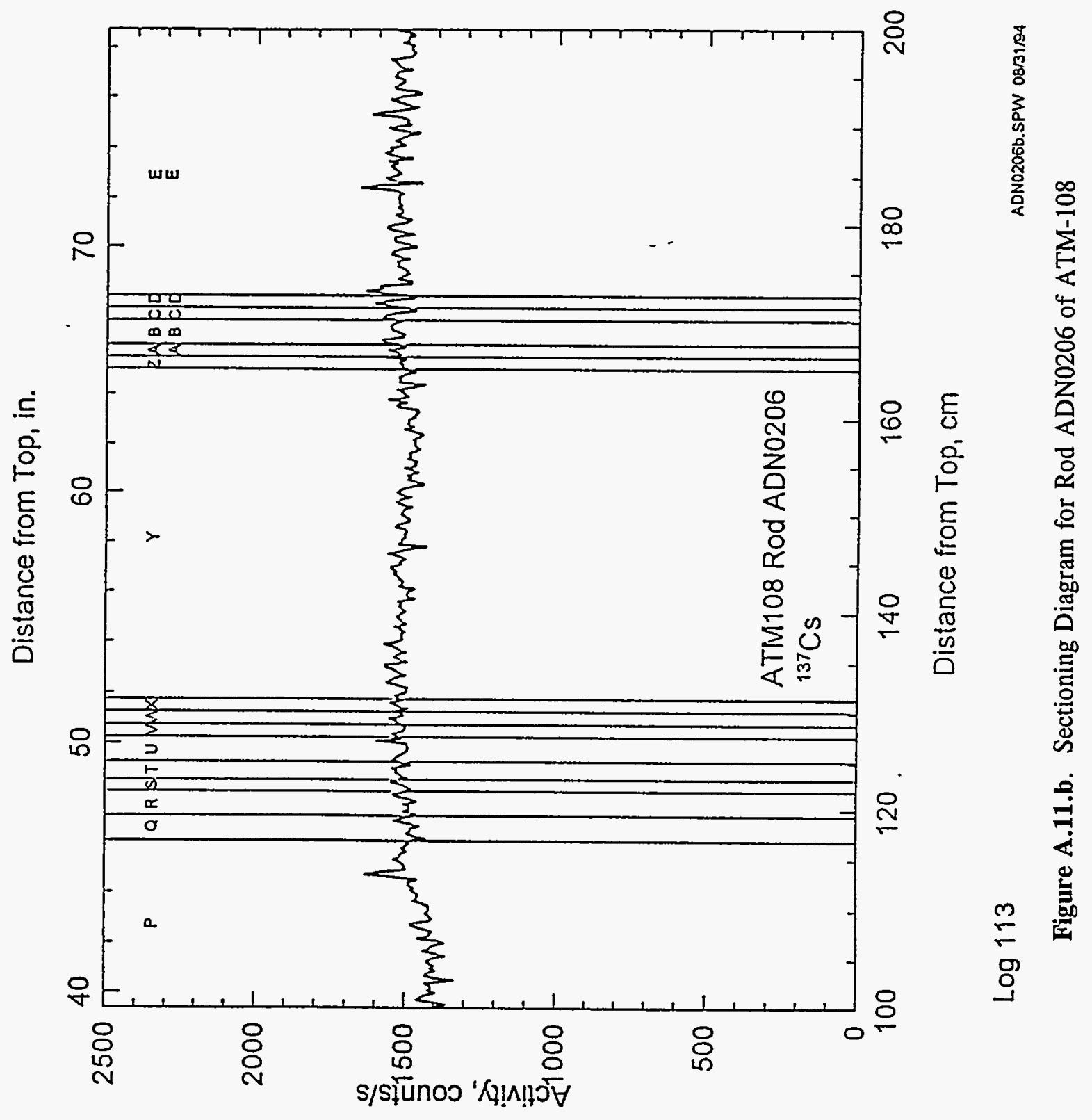




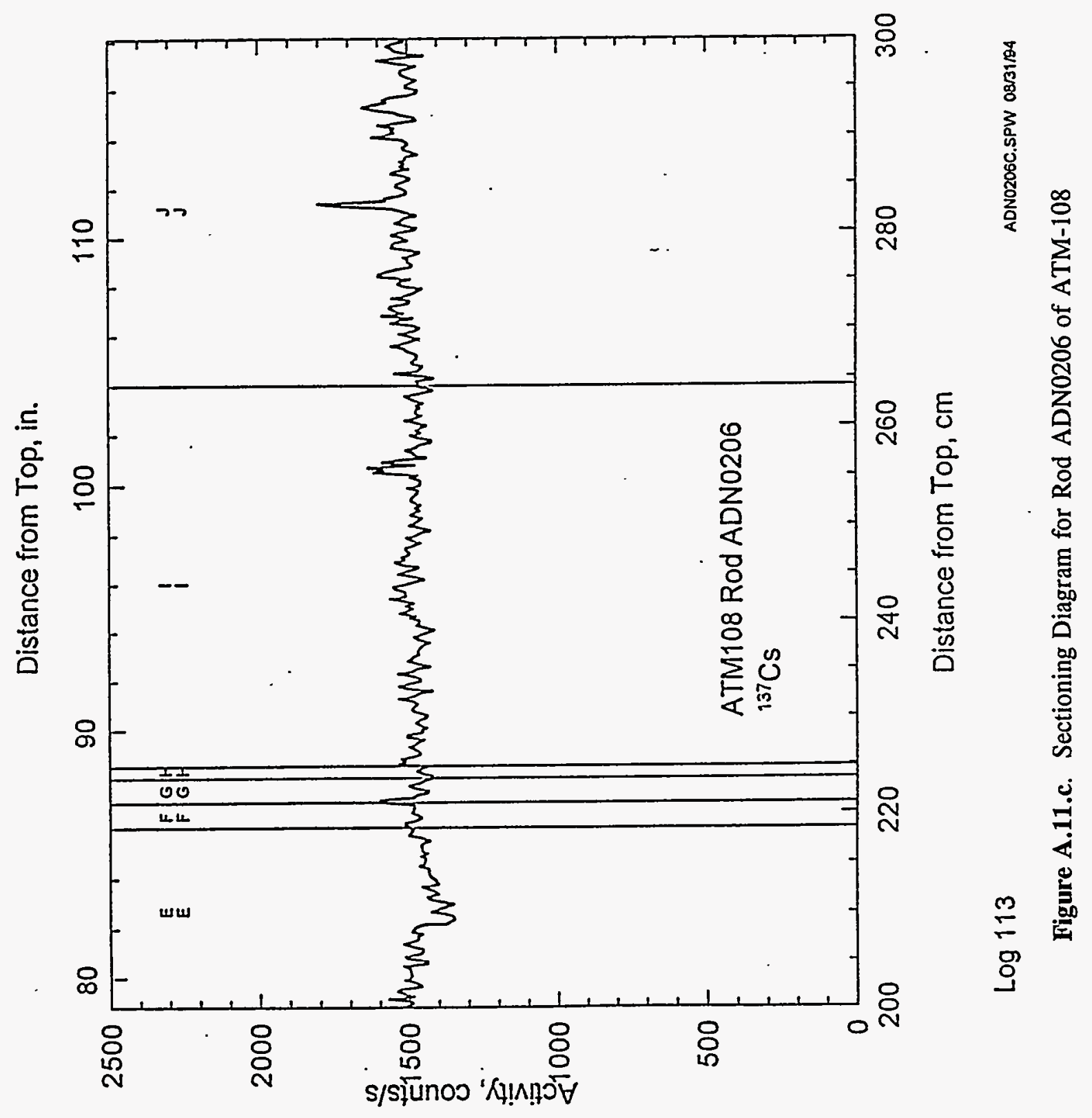




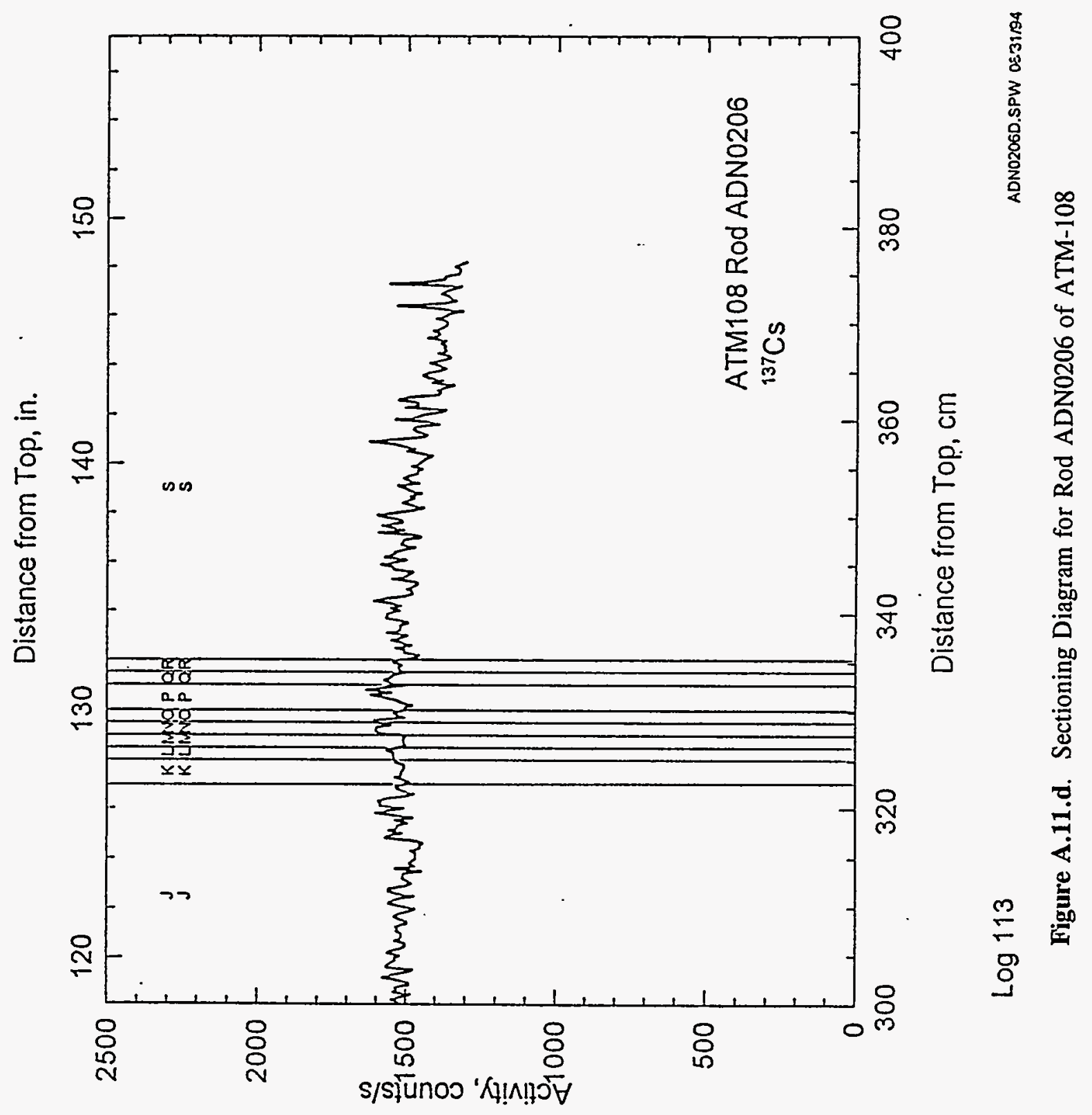




\section{Appendix B}

\section{Radiochemical Analyses}




\section{Appendix B}

\section{Radiochemical Analyses}

Available radiochemical analyses for Rods MLA091, MKP070, NBD095, NBD131, and ADN0206 are provided in Table B.1. The hydrogen content in the cladding of samples from the lower third of Rod G13 of ATM-101 (G13B) and from the upper third of this rod (G13T) are also reported. Design and power history data are provided in Barner (1985). Information in the table includes the ATM rod number, section number as identified in the sectioning diagrams of Appen$\operatorname{dix} A$, the sample number used to mark transfer containers and maintain identity of the samples during radiochemical analyses, the number of the analytical request, the type of analyses, the measured values, uncertainties assigned to the measured value according to the completed analytical requests, and the date the measurement was made. The number of analyses reported varies because some of the rods were not examined as extensively and multiple analyses are reported for some samples. Only the analyses for burnup and a few isotopes were completed from three samples of Rod ADN0206. Analytical results for the fuel and cladding are presented first, followed by the gas analyses where available. All of the data in this appendix meet the Impact Level I requirements of PNL-MA-70, which is consistent with NQA-1 quality assurance. 


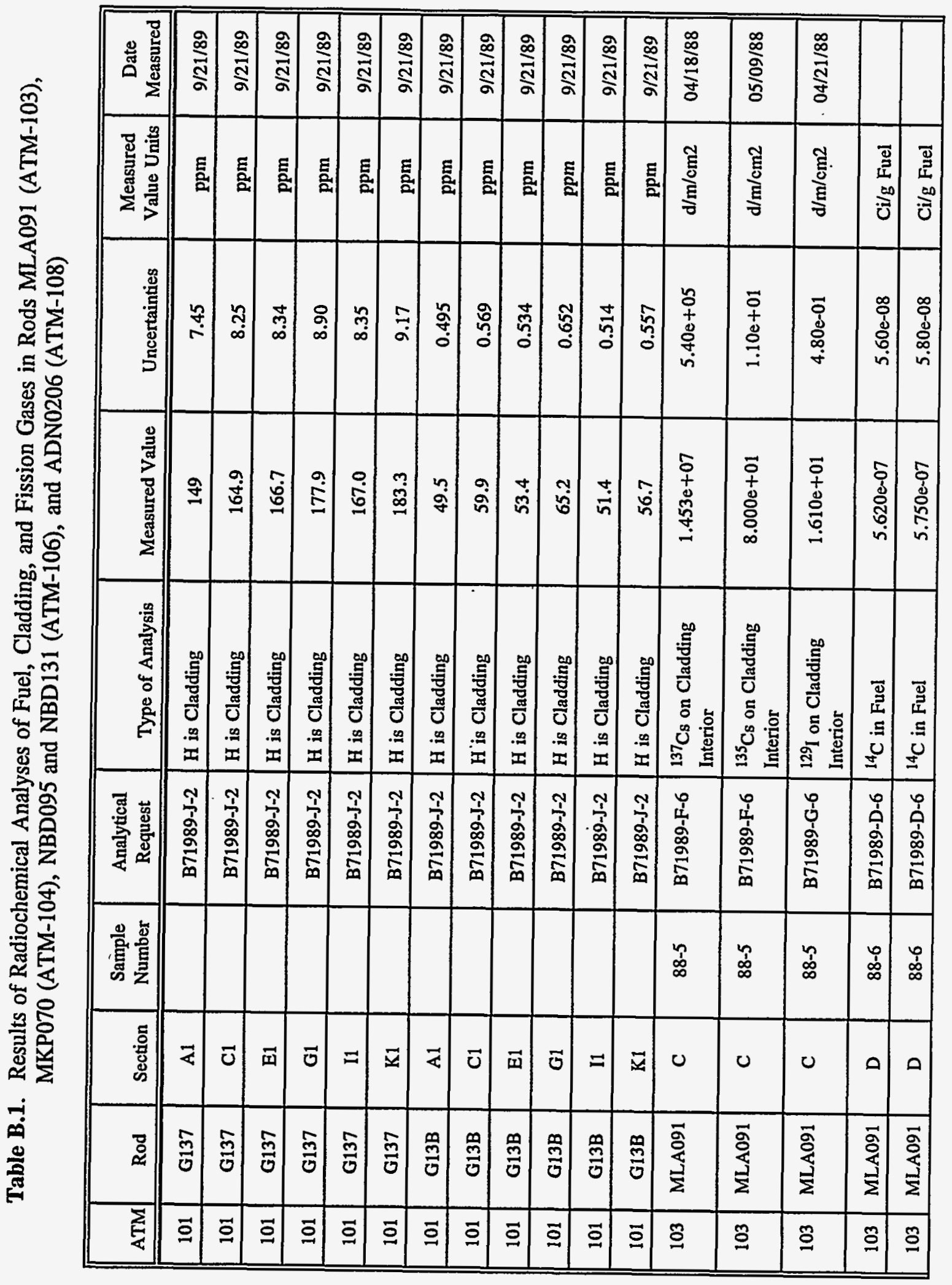


Table B.1. (contd)

\begin{tabular}{|c|c|c|c|c|c|c|c|c|c|}
\hline ATM & Rod & Section & $\begin{array}{l}\text { Sample } \\
\text { Number }\end{array}$ & $\begin{array}{l}\text { Analytical } \\
\text { Request }\end{array}$ & Type of Analysis & Measured Value & Uncertainties & $\begin{array}{c}\text { Measured } \\
\text { Value Units }\end{array}$ & $\begin{array}{c}\text { Date } \\
\text { Measured }\end{array}$ \\
\hline 103 & MLA091 & D & $88-6$ & B71989-E-6 & ${ }^{14} \mathrm{C}$ in Cladding & $1.560 \mathrm{e}-07$ & $1.60 \mathrm{e}-08$ & $\mathrm{Ci} / \mathrm{g} \mathrm{Zr}$ & \\
\hline 103 & MLA091 & $\mathrm{D}$ & $88-6$ & B71989-E-6 & ${ }^{14} \mathrm{C}$ in Cladding & $4.360 \mathrm{e}-07$ & $4.40 \mathrm{e}-08$ & $\mathrm{Ci} / \mathrm{g} \mathrm{Zr}$ & \\
\hline 103 & MLA091 & $\mathbf{F}$ & $88-7$ & B71989-F-6 & $\begin{array}{l}{ }^{137} \mathrm{Cs} \text { on Cladding } \\
\text { Interior }\end{array}$ & $2.492 \mathrm{e}+07$ & $9.20 \mathrm{e}+05$ & $\mathrm{~d} / \mathrm{m} / \mathrm{cm} 2$ & $04 / 18 / 88$ \\
\hline 103 & MLA091 & F & $88-7$ & B71989-F-6 & $\begin{array}{l}{ }^{135} \mathrm{Cs} \text { on Cladding } \\
\text { Interior }\end{array}$ & $1.100 \mathrm{e}+02$ & $1.50 \mathrm{e}+01$ & $\mathrm{~d} / \mathrm{m} / \mathrm{cm} 2$ & $05 / 09 / 88$ \\
\hline 103 & MLA091 & F & $88-7$ & B71989-G-6 & $\begin{array}{l}129 \text { I on Cladding } \\
\text { Interior }\end{array}$ & $6.360 e+01$ & $1.90 e+00$ & $\mathrm{~d} / \mathrm{m} / \mathrm{cm} 2$ & $04 / 21 / 88$ \\
\hline 103 & MLA091 & G & $88-8$ & B71989-D-6 & ${ }^{14} \mathrm{C}$ in Fuel & $7.320 \mathrm{e}-07$ & $7.30 \mathrm{e}-08$ & $\mathrm{Ci} / \mathrm{g}$ Fuel & \\
\hline 103 & MLA091 & $\mathbf{G}$ & $88-8$ & B71989-D-6 & ${ }^{14} \mathrm{C}$ in Fuel & $7.320 \mathrm{e}-07$ & $7.30 \mathrm{e}-08$ & $\mathrm{Ci} / \mathrm{g}$ fuel & \\
\hline 103 & MLA091 & $\mathbf{G}$ & $88-8$ & B71989-E-6 & ${ }^{14} \mathrm{C}$ in Cladding & $5.290 \mathrm{e}-07$ & $5.30 \mathrm{e}-08$ & $\mathrm{Ci} / \mathrm{g} \mathrm{Zr}$ & \\
\hline 103 & MLA091 & $G$ & $88-8$ & B71989-E-6 & ${ }^{14} \mathrm{C}$ in Cladding & $6.860 \mathrm{e}-07$ & $6.90 \mathrm{e}-08$ & $\mathrm{Ci} / \mathrm{g} \mathrm{Zr}$ & \\
\hline 103 & MLA091 & $\mathbf{J}$ & $88-10$ & B71989-B-6 & $\begin{array}{l}\text { Measured Fuel } \\
\text { Burnup }\end{array}$ & $3.291 \mathrm{e}+01$ & & $\mathrm{MWd} / \mathrm{kgM}$ & \\
\hline 103 & MLA091 & $\mathbf{J}$ & $88-10$ & B71989-B-6 & ${ }^{234} \mathrm{U}$ & $1.400 \mathrm{e}-02$ & $1.00 \mathrm{e}-03$ & ${ }^{234} \mathrm{U}$ wt\% & \\
\hline 103 & MLA091 & J & $88-10$ & B71989-B-6 & ${ }^{235} \mathrm{U}$ & $6.090 \mathrm{e}-01$ & $7.00 \mathrm{e}-03$ & ${ }^{235} \mathrm{U} w t \%$ & \\
\hline 103 & MLA091 & J & $88-10$ & B71989-B-6 & ${ }^{236} \mathrm{U}$ & $3.800 \mathrm{e}-01$ & $4.00 \mathrm{e}-03$ & ${ }^{236} \mathrm{U} w t \%$ & \\
\hline 103 & MLA091 & $\mathrm{J}$ & $88-10$ & B71989-B-6 & ${ }^{238} \mathrm{U}$ & $9.900 e+01$ & $2.00 \mathrm{e}-02$ & ${ }^{238} \mathrm{U}$ wt\% & \\
\hline 103 & MLA091 & J & $88-10$ & B71989-B-6 & ${ }^{238} \mathrm{Pu}$ & $2.273 \mathrm{e}+00$ & $6.90 \mathrm{e}-02$ & ${ }^{238} \mathrm{Pu}$ wt $\%$ & \\
\hline 103 & MLA091 & J & $88-10$ & B71989-B-6 & ${ }^{239} \mathrm{Pu}$ & $5.472 \mathrm{e}+01$ & $1.60 \mathrm{e}-01$ & ${ }^{239} \mathrm{Pu} w \mathrm{t} \%$ & \\
\hline 103 & MLA091 & J & $88-10$ & B71989-B-6 & ${ }^{240} \mathrm{Pu}$ & $2.700 e+01$ & $1.60 \mathrm{e}-01$ & ${ }^{240} \mathrm{Pu}$ wt $\%$ & \\
\hline 103 & MLA091 & $\mathrm{J}$ & $88-10$ & B71989-B-6 & ${ }^{241} \mathrm{Pu}$ & $9.600 \mathrm{e}+00$ & $7.70 \mathrm{e}-02$ & ${ }^{241} \mathrm{Pu}$ wt\% & \\
\hline 103 & MLA091 & J & $88-10$ & B71989-B-6 & ${ }^{242} \mathrm{Pu}$ & $6.415 e+00$ & $1.00 \mathrm{e}-01$ & ${ }^{242} \mathrm{Pu}$ wt $\%$ & \\
\hline
\end{tabular}


Table B.1. (contd)

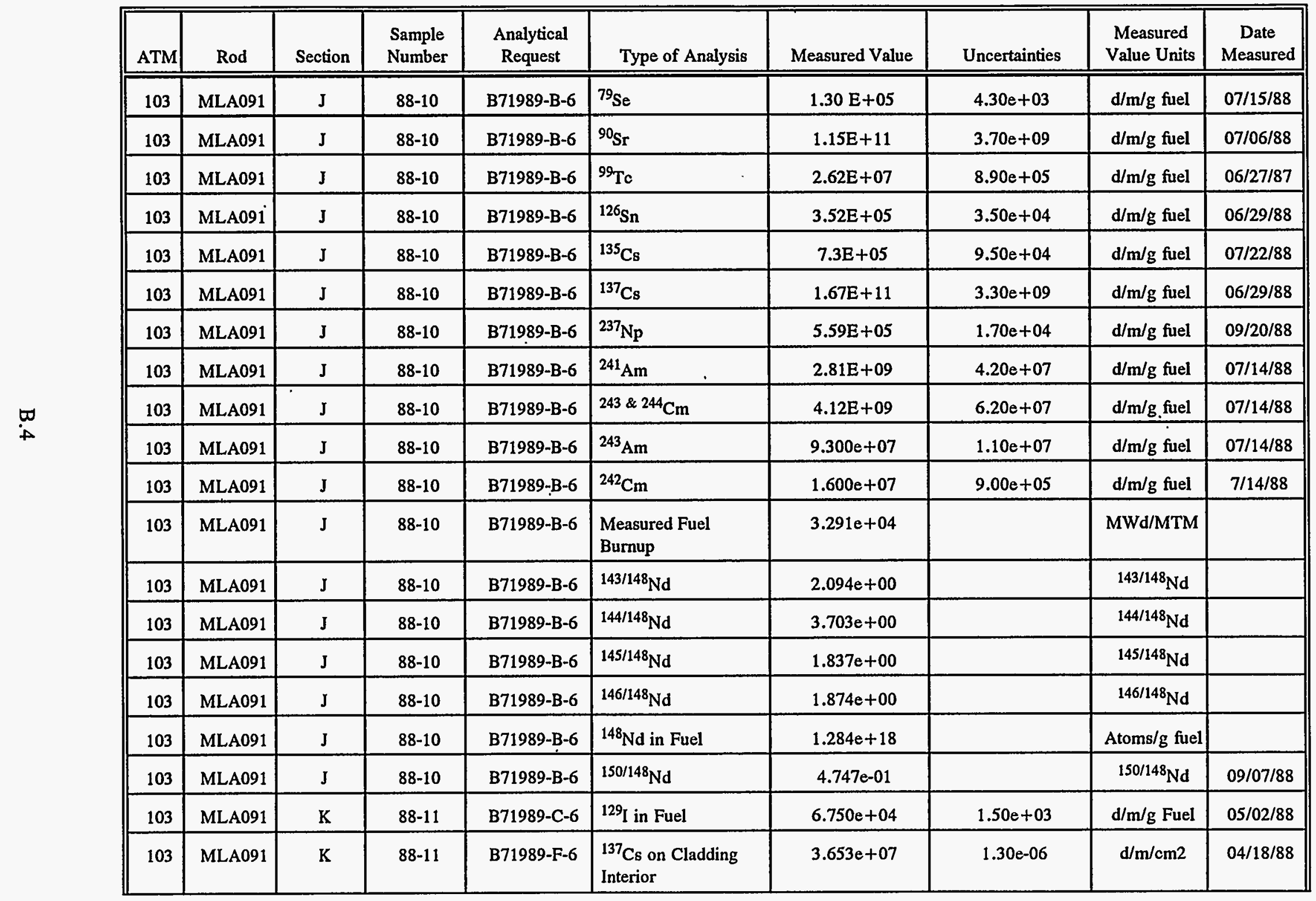


Table B.1. (contd)

\begin{tabular}{|c|c|c|c|c|c|c|c|c|c|}
\hline ATM & Rod & Section & $\begin{array}{l}\text { Sample } \\
\text { Number }\end{array}$ & $\begin{array}{l}\text { Analytical } \\
\text { Request }\end{array}$ & Type of Analysis & Measured Value & Uncertainties & $\begin{array}{c}\text { Measured } \\
\text { Value Units }\end{array}$ & $\begin{array}{c}\text { Date } \\
\text { Measured }\end{array}$ \\
\hline 103 & MLA091 & $\mathbf{K}$ & $88-11$ & B71989-F-6 & $\begin{array}{l}{ }^{135} \mathrm{C} s \text { on Cladding } \\
\text { Interior }\end{array}$ & $1.590 e+02$ & $2.20 \mathrm{e}+01$ & $\mathrm{~d} / \mathrm{m} / \mathrm{cm} 2$ & $05 / 09 / 88$ \\
\hline 103 & MLA091 & $\mathrm{K}$ & $88-11$ & B71989-G-6 & $\begin{array}{l}{ }^{129} \text { I on Cladding } \\
\text { Interior }\end{array}$ & $5.840 e+01$ & $1.80 \mathrm{e}+00$ & $\mathrm{~d} / \mathrm{m} / \mathrm{cm} 2$ & $04 / 20 / 88$ \\
\hline 103 & MLA091 & $\mathrm{L}$ & $88-12$ & B71989-D-6 & ${ }^{14} \mathrm{C}$ in Fuel & $7.640 \mathrm{e}-07$ & $7.60 \mathrm{e}-08$ & $\mathrm{Ci} / \mathrm{g}$ Fuel & \\
\hline 103 & MLA091 & L & $88-12$ & B71989-D-6 & ${ }^{14} \mathrm{C}$ in Fuel & $7.720 \mathrm{e}-07$ & $7.70 \mathrm{e}-08$ & $\mathrm{Ci} / \mathrm{g}$ Fuel & \\
\hline 103 & MLA091 & $\mathrm{L}$ & $88-12$ & B71989-E-6 & ${ }^{14} \mathrm{C}$ in Cladding & $5.160 \mathrm{e}-07$ & $5.20 \mathrm{e}-08$ & $\mathrm{Ci} / \mathrm{g}_{\mathrm{Zr}}$ & \\
\hline 103 & MLA091 & $\mathbf{L}$ & $88-12$ & B71989-E-6 & ${ }^{14} \mathrm{C}$ in Cladding & $8.460 \mathrm{e}-07$ & $8.50 \mathrm{e}-08$ & $\mathrm{Ci} / \mathrm{g} \mathrm{Zr}$ & \\
\hline 103 & MLA091 & $\mathbf{0}$ & $88-13$ & B71989-C-6 & ${ }^{129} \mathrm{I}$ in Fuel & $5.000 \mathrm{e}+04$ & $1.10 e+03$ & $\mathrm{~d} / \mathrm{m} / \mathrm{g}$ Fuel & $05 / 02 / 88$ \\
\hline 103 & MLA091 & o & $88-13$ & B71989-F-6 & $\begin{array}{l}{ }^{137} \mathrm{Cs} \text { on Cladding } \\
\text { Interior }\end{array}$ & $1.667 e+07$ & $6.20 \mathrm{e}+05$ & $\mathrm{~d} / \mathrm{m} / \mathrm{cm} 2$ & $04 / 18 / 88$ \\
\hline 103 & MLA091 & 0 & $88-13$ & B71989-F-6 & $\begin{array}{l}{ }^{135} \mathrm{Cs} \text { on Cladding } \\
\text { Interior }\end{array}$ & $8.500 e+01$ & $1.20 \mathrm{e}+01$ & $\mathrm{~d} / \mathrm{m} / \mathrm{cm} 2$ & $05 / 09 / 88$ \\
\hline 103 & MLA091 & 0 & $88-13$ & B71989-G-6 & $\begin{array}{l}{ }^{129} \mathrm{I} \text { on Cladding } \\
\text { Interior }\end{array}$ & $2.020 \mathrm{e}+01$ & $6.10 \mathrm{e}-01$ & $\mathrm{~d} / \mathrm{m} / \mathrm{cm} 2$ & $05 / 02 / 88$ \\
\hline 103 & MLA091 & $\mathrm{P}$ & $88-14$ & B71989-D-6 & ${ }^{14} \mathrm{C}$ in Fuel & $5.580 e-07$ & $5.60 \mathrm{e}-08$ & $\mathrm{Ci} / \mathrm{g}$ Fuel & \\
\hline 103 & MLA091 & $\mathbf{P}$ & $88-14$ & B71989-D-6 & ${ }^{14} \mathrm{C}$ in Fuel & $5.630 \mathrm{e}-07$ & $5.60 \mathrm{e}-08$ & $\mathrm{Ci} / \mathrm{g}$ Fuel & \\
\hline 103 & MLA091 & $\mathbf{P}$ & $88-14$ & B71989-E-6 & ${ }^{14} \mathrm{C}$ in Cladding & $5.960 \mathrm{e}-07$ & $6.00 e-08$ & $\mathrm{Ci} / \mathrm{g} \mathrm{Zr}$ & \\
\hline 103 & MLA091 & $\mathbf{P}$ & $88-14$ & B71989-E-6 & ${ }^{14} \mathrm{C}$ in Cladding & $2.250 \mathrm{e}-07$ & $2.30 \mathrm{e}-08$ & $\mathrm{Ci} / \mathrm{g} \mathrm{Zr}$ & \\
\hline 103 & MLA091 & $\mathbf{R}$ & $88-15$ & B71989-C-6 & ${ }^{129} \mathrm{I}$ in Fuel & $2.960 \mathrm{e}+04$ & $6.50 e+02$ & $\mathrm{~d} / \mathrm{m} / \mathrm{g}$ Fuel & $05 / 02 / 88$ \\
\hline 103 & MLA091 & $\mathbf{R}$ & $88-15$ & B71989-F-6 & $\begin{array}{l}{ }^{137} \mathrm{Cs} \text { on Cladding } \\
\text { Interior }\end{array}$ & $1.124 \mathrm{e}+07$ & $4.20 \mathrm{e}+05$ & $\mathrm{~d} / \mathrm{m} / \mathrm{cm} 2$ & $04 / 18 / 88$ \\
\hline 103 & MLA091 & $\mathrm{R}$ & $88-15$ & B71989-F-6 & $\begin{array}{l}{ }^{135} \mathrm{Cs} \text { on Cladding } \\
\text { Interior }\end{array}$ & $7.800 e+01$ & $1.10 \mathrm{e}+01$ & $\mathrm{~d} / \mathrm{m} / \mathrm{cm} 2$ & $05 / 09 / 88$ \\
\hline
\end{tabular}


Table B.1. (contd)

\begin{tabular}{|c|c|c|c|c|c|c|c|c|c|}
\hline ATM & Rod & Section & $\begin{array}{l}\text { Sample } \\
\text { Number }\end{array}$ & $\begin{array}{c}\text { Analytical } \\
\text { Request }\end{array}$ & Type of Analysis & Measured Value & Uncertainties & $\begin{array}{c}\text { Measured } \\
\text { Value Units } \\
\end{array}$ & $\begin{array}{c}\text { Date } \\
\text { Measured } \\
\end{array}$ \\
\hline 103 & MLA091 & $\mathbf{R}$ & $88-15$ & B71989-G-6 & $\begin{array}{l}129 \text { I on Cladding } \\
\text { Interior }\end{array}$ & $7.100 e+00$ & $2.10 \mathrm{e}-01$ & $\mathrm{~d} / \mathrm{m} / \mathrm{cm} 2$ & $05 / 03 / 88$ \\
\hline 103 & MLA091 & s & $88-16$ & B71989-D-6 & ${ }^{14} \mathrm{C}$ in Fuel & $3.110 \mathrm{e}-07$ & $3.10 \mathrm{e}-08$ & $\mathrm{Ci} / \mathrm{g}$ Fuel & \\
\hline 103 & MLA091 & $\mathbf{s}$ & $88-16$ & B71989-D-6 & ${ }^{14} \mathrm{C}$ in Fuel & $2.960 \mathrm{e}-07$ & $3.00 \mathrm{e}-08$ & $\mathrm{Ci} / \mathrm{g}$ Fuel & \\
\hline 103 & MLA091 & $\mathbf{s}$ & $88-16$ & B71989-E-6 & ${ }^{14} \mathrm{C}$ in Cladding & $2.720 \mathrm{e}-07$ & $2.70 \mathrm{e}-08$ & $\mathrm{Ci} / \mathrm{g} \mathrm{Zr}$ & \\
\hline 103 & MLA091 & $\mathbf{s}$ & $88-16$ & B71989-E-6 & ${ }^{14} \mathrm{C}$ in Cladding & $1.530 \mathrm{e}-07$ & $1.50 \mathrm{e}-08$ & $\mathrm{Ci} / \mathrm{g} \mathrm{Zr}$ & \\
\hline 104 & MKP070 & C & $88-48$ & B71989-C-8 & ${ }^{129} I$ in Fuel & $6.610 \mathrm{e}+04$ & $1.90 \mathrm{e}+03$ & $\mathrm{~d} / \mathrm{m} / \mathrm{g}$ Fuel & $09 / 14 / 88$ \\
\hline 104 & MKP070 & C & $88-48$ & B71989-F-8 & $\begin{array}{l}{ }^{137} \mathrm{Cs} \text { on Cladding } \\
\text { Interior }\end{array}$ & $2.000 e+07$ & $7.60 \mathrm{e}+05$ & $\mathrm{~d} / \mathrm{m} / \mathrm{cm} 2$ & $09 / 28 / 88$ \\
\hline 104 & MKP070 & C & $88-48$ & B71989-F-8 & $\begin{array}{l}{ }^{135} \mathrm{Cs} \text { on Cladding } \\
\text { Interior }\end{array}$ & $1.150 \mathrm{e}+02$ & $1.60 \mathrm{e}+01$ & $\mathrm{~d} / \mathrm{m} / \mathrm{cm} 2$ & $09 / 28 / 88$ \\
\hline 104 & MKP070 & C & $88-48$ & B71989-G-8 & $\begin{array}{l}{ }^{129} \text { I on Cladding } \\
\text { Interior } \\
\end{array}$ & $1.620 \mathrm{e}+01$ & $4.90 \mathrm{e}-01$ & $\mathrm{~d} / \mathrm{m} / \mathrm{cm} 2$ & $09 / 15 / 88$ \\
\hline 104 & MKP070 & D & $88-49$ & B71989-D-8 & ${ }^{14} \mathrm{C}$ in Fuel & $7.140 \mathrm{e}-07$ & $7.10 \mathrm{e}-08$ & $\mathrm{Ci} / \mathrm{g}$ Fuel & \\
\hline 104 & MKP070 & D & $88-49$ & B71989-D-8 & ${ }^{14} \mathrm{C}$ in Fuel & $6.650 \mathrm{e}-07$ & $6.70 \mathrm{e}-08$ & $\mathrm{Ci} / \mathrm{g}$ Fuel & \\
\hline 104 & MKP070 & $\mathrm{D}$ & $88-49$ & B71989-E-8 & ${ }^{14} \mathrm{C}$ in Cladding & $2.230 \mathrm{e}-07$ & $2.20 \mathrm{e}-08$ & $\mathrm{Ci} / \mathrm{g} \mathrm{Zr}$ & \\
\hline 104 & MKP070 & D & $88-49$ & B71989-E-8 & ${ }^{14} \mathrm{C}$ in Cladding & $3.140 \mathrm{e}-07$ & $3.10 \mathrm{e}-08$ & $\mathrm{Ci} / \mathrm{g} \mathrm{Zr}$ & \\
\hline 104 & MKP070 & $\mathbf{F}$ & $88-50$ & B71989-F-8 & \begin{tabular}{|l}
${ }^{137} \mathrm{Cs}$ on Cladding \\
Interior \\
\end{tabular} & $2.080 e+08$ & $7.90 \mathrm{e}+06$ & $\mathrm{~d} / \mathrm{m} / \mathrm{cm} 2$ & $09 / 28 / 88$ \\
\hline 104 & MKP070 & $\mathrm{F}$ & $88-50$ & B71989-F-8 & $\begin{array}{l}{ }^{135} \mathrm{Cs} \text { on Cladding } \\
\text { Interior } \\
\end{array}$ & $9.520 e+03$ & $1.30 \mathrm{e}+03$ & $\mathrm{~d} / \mathrm{m} / \mathrm{cm} 2$ & $09 / 28 / 88$ \\
\hline 104 & MKP070 & F & $88-50$ & B71989-G-8 & $\begin{array}{l}{ }^{129} \text { I on Cladding } \\
\text { Interior }\end{array}$ & $1.260 \mathrm{e}+02$ & $3.70 e+00$ & $\mathrm{~d} / \mathrm{m} / \mathrm{cm} 2$ & $09 / 15 / 88$ \\
\hline 104 & MKP070 & G & $88-51$ & B71989-D-8 & ${ }^{14} \mathrm{C}$ in Fuel & $9.980 \mathrm{e}-07$ & $1.00 \mathrm{e}-07$ & $\mathrm{Ci} / \mathrm{g}$ Fuel & \\
\hline
\end{tabular}


Table B.1. (contd)

\begin{tabular}{|c|c|c|c|c|c|c|c|c|c|}
\hline ATM & Rod & Section & $\begin{array}{l}\text { Sample } \\
\text { Number }\end{array}$ & $\begin{array}{c}\text { Analytical } \\
\text { Request }\end{array}$ & Type of Analysis & Measured Value & Uncertainties & $\begin{array}{c}\text { Measured } \\
\text { Value Units }\end{array}$ & $\begin{array}{c}\text { Date } \\
\text { Measured }\end{array}$ \\
\hline 104 & MKP070 & $G$ & $88-51$ & B71989-D-8 & ${ }^{14} \mathrm{C}$ in Fuel & $1.003 \mathrm{e}-06$ & $1.00 \mathrm{e}-07$ & $\mathrm{Ci} / \mathrm{g}$ Fuel & \\
\hline 104 & MKP070 & G & $88-51$ & B71989-E-8 & ${ }^{14} \mathrm{C}$ in Cladding & $9.470 \mathrm{e}-07$ & $9.50 \mathrm{e}-08$ & $\mathrm{Ci} / \mathrm{g} \mathrm{Zr}$ & \\
\hline 104 & MKP070 & G & $88-51$ & B71989-E-8 & ${ }^{14} \mathrm{C}$ in Cladding & $9.700 \mathrm{e}-07$ & $9.70 \mathrm{e}-08$ & $\mathrm{Ci} / \mathrm{g} \mathrm{Zr}$ & \\
\hline 104 & MKP070 & J & $88-53$ & B71989-B-8 & $\begin{array}{l}\text { Measured Fuel } \\
\text { Burnup }\end{array}$ & $4.375 \mathrm{e}+01$ & & $\mathrm{MWd} / \mathrm{kgM}$ & \\
\hline 104 & MKP070 & J & $88-53$ & B71989-B-8 & ${ }^{234} \mathrm{U}$ & $1.500 \mathrm{e}-02$ & $2.00 \mathrm{e}-03$ & ${ }^{234} \mathrm{U} w t \%$ & \\
\hline 104 & MKP070 & $\mathbf{J}$ & $88-53$ & B71989-B-8 & ${ }^{235} \mathrm{U}$ & $4.140 \mathrm{e}-01$ & $6.00 \mathrm{e}-03$ & ${ }^{235} \mathrm{U}$ wt\% & \\
\hline 104 & MKP070 & $\mathrm{J}$ & 88-53 & B71989-B-8 & ${ }^{236} \mathrm{U}$ & $4.460 \mathrm{e}-01$ & $6.00 \mathrm{e}-03$ & ${ }^{236} \mathrm{U} w \mathrm{t} \%$ & \\
\hline 104 & MKP070 & $\mathrm{J}$ & $88-53$ & B71989-B-8 & ${ }^{238} \mathrm{U}$ & $9.912 e+01$ & $1.20 \mathrm{e}-02$ & ${ }^{238} \mathrm{U} w t \%$ & \\
\hline 104 & MKP070 & $\mathrm{J}$ & $88-53$ & B71989-B-8 & ${ }^{238} \mathrm{Pu}$ & $2.937 e+00$ & $2.00 \mathrm{e}-02$ & ${ }^{238} \mathrm{Pu}$ wt $\%$ & \\
\hline 104 & MKP070 & $J$ & $88-53$ & B71989-B-8 & ${ }^{239} \mathrm{Pu}$ & $4.842 e+01$ & $1.50 \mathrm{e}-01$ & ${ }^{239} \mathrm{Pu} w t \%$ & \\
\hline 104 & MKP070 & $\mathrm{J}$ & $88-53$ & B71989-B-8 & ${ }^{240} \mathrm{Pu}$ & $2.861 e+01$ & $1.50 \mathrm{e}-01$ & ${ }^{240} \mathrm{Pu} w t \%$ & \\
\hline 104 & MKP070 & $\mathrm{J}$ & $88-53$ & B71989-B-8 & ${ }^{241} \mathrm{Pu}$ & $1.060 e+01$ & $1.00 \mathrm{e}-01$ & ${ }^{241} \mathrm{Pu}$ wt\% & \\
\hline 104 & MKP070 & $\mathrm{J}$ & $88-53$ & B71989-B-8 & ${ }^{242} \mathrm{Pu}$ & $9.445 e+00$ & $9.00 \mathrm{e}-02$ & ${ }^{242} \mathrm{Pu} w t \%$ & \\
\hline 104 & MKP070 & $\mathrm{J}$ & 88.53 & B71989-B-8 & ${ }^{79} \mathrm{Se}$ & $1.400 e+05$ & $7.40 e+03$ & $\mathrm{~d} / \mathrm{m} / \mathrm{g}$ fuel & $09 / 23 / 88$ \\
\hline 104 & MKP070 & $\mathrm{J}$ & $88-53$ & B71989-B-8 & ${ }^{90} \mathrm{Sr}$ & $8.760 e+10$ & $6.00 \mathrm{e}+09$ & $\mathrm{~d} / \mathrm{m} / \mathrm{g}$ fuel & $09 / 21 / 88$ \\
\hline 104 & MKP070 & $J$ & $88-53$ & B71989-B-8 & ${ }^{99} \mathrm{Tc}$ & $3.770 e+07$ & $1.70 e+06$ & $\mathrm{~d} / \mathrm{m} / \mathrm{g}$ fuel & $09 / 21 / 88$ \\
\hline 104 & MKP070 & $\mathrm{J}$ & $88-53$ & B71989-B-8 & ${ }^{126} \mathrm{Sn}$ & $5.260 e+05$ & $5.50 \mathrm{e}+04$ & $\mathrm{~d} / \mathfrak{m} / \mathrm{g}$ fuel & $09 / 20 / 88$ \\
\hline 104 & MKP070 & $\mathrm{J}$ & $88-53$ & B71989-B-8 & ${ }^{135} \mathrm{Cs}$ & $1.090 e+06$ & $1.50 \mathrm{e}+05$ & $\mathrm{~d} / \mathrm{m} / \mathrm{g}$ fuel & $10 / 03 / 88$ \\
\hline 104 & MKP070 & $\mathrm{J}$ & $88-53$ & B71989-B-8 & ${ }^{137} \mathrm{Cs}$ & $2.320 e+11$ & $8.60 e+09$ & $\mathrm{~d} / \mathrm{m} / \mathrm{g}$ fuel & $10 / 03 / 88$ \\
\hline 104 & MKP070 & J & $88-53$ & B71989-B-8 & ${ }^{237} \mathrm{~Np}$ & $5.610 e+05$ & $1.08 \mathrm{e}+05$ & $\mathrm{~d} / \mathrm{m} / \mathrm{g}$ fuel & $09 / 20 / 88$ \\
\hline
\end{tabular}


Table B.1. (contd)

\begin{tabular}{|c|c|c|c|c|c|c|c|c|c|}
\hline ATM & Rod & Section & $\begin{array}{l}\text { Sample } \\
\text { Number }\end{array}$ & $\begin{array}{l}\text { Analytical } \\
\text { Request }\end{array}$ & Type of Analysis & Measured Value & Uncertainties & $\begin{array}{c}\text { Measured } \\
\text { Value Units } \\
\end{array}$ & $\begin{array}{c}\text { Date } \\
\text { Measured }\end{array}$ \\
\hline 104 & MKP070 & J & $88-53$ & B71989-B-8 & ${ }^{237} \mathrm{~Np}$ & $7.370 e+05$ & $1.43 e+05$ & $\mathrm{~d} / \mathrm{m} / \mathrm{g}$ fuel & $09 / 20 / 88$ \\
\hline 104 & MKP070 & J & $88-53$ & B71989-B-8 & ${ }^{241} \mathrm{Am}$ & $3.020 e+09$ & $4.80 e+07$ & $\mathrm{~d} / \mathrm{m} / \mathrm{g}$ fuel & $09 / 15 / 88$ \\
\hline 104 & MKP070 & $\mathbf{J}$ & $88-53$ & B71989-B-8 & ${ }^{243} \& 244 \mathrm{Cm}$ & $1.250 e+10$ & $6.50 e+07$ & $\mathrm{~d} / \mathrm{m} / \mathrm{g}$ fuel & $09 / 15 / 88$ \\
\hline 104 & MKP070 & $\mathrm{J}$ & $88-53$ & B71989-B-8 & ${ }^{243} \mathrm{Am}$ in Fuel & $1.540 e+08$ & $2.10 e+07$ & $\mathrm{~d} / \mathbf{m} / \mathrm{g}$ Fuel & $09 / 15 / 88$ \\
\hline 104 & MKP070 & J & $88-53$ & B71989-B-8 & ${ }^{242} \mathrm{Cm}$ in Fuel & $3.450 e+07$ & $7.00 e+06$ & $\mathrm{~d} / \mathrm{m} / \mathrm{g}$ Fuel & $09 / 15 / 88$ \\
\hline 104 & MKP070 & $\mathbf{J}$ & $88-53$ & B71989-B-8 & $\begin{array}{l}\text { Measured Fuel } \\
\text { Burnup }\end{array}$ & $4.375 e+04$ & & $\mathrm{MWd} / \mathrm{MTM}$ & $12 / 09 / 88$ \\
\hline 104 & MKP070 & J & $88-53$ & B71989-B-8 & ${ }^{143 / 148} \mathrm{Nd}$ & $1.795 \mathrm{e}+00$ & & ${ }^{143 / 148} \mathrm{Nd}$ & $12 / 09 / 88$ \\
\hline 104 & MKP070 & $\mathrm{J}$ & $88-53$ & B71989-B-8 & ${ }^{144 / 148} \mathrm{Nd}$ & $3.898 e+00$ & & $144 / 148 \mathrm{Nd}$ & $12 / 09 / 88$ \\
\hline 104 & MKP070 & J & $88-53$ & B71989-B-8 & ${ }^{145 / 148} \mathrm{Nd}$ & $1.742 e+00$ & & $145 / 148 \mathrm{Nd}$ & $12 / 09 / 88$ \\
\hline 104 & MKP070 & J & $88-53$ & B71989-B-8 & ${ }^{146 / 148} \mathrm{Nd}$ & $1.939 e+00$ & & $146 / 148 \mathrm{Nd}$ & $12 / 09 / 88$ \\
\hline 104 & MKP070 & J & $88-53$ & B71989-B-8 & ${ }^{148} \mathrm{Nd}$ in Fuel & $1.738 e+18$ & & Atoms/g Fuel & $12 / 09 / 88$ \\
\hline 104 & MKP070 & J & $88-53$ & B71989-B-8 & ${ }^{150 / 148} \mathrm{Nd}$ & $4.833 \mathrm{e}-01$ & & ${ }^{150 / 148} \mathrm{Nd}$ & $12 / 09 / 88$ \\
\hline 104 & MKP070 & $\mathrm{L}$ & $88-55$ & B71989-C-8 & ${ }^{129} \mathrm{I}$ in Fuel & $1.030 \mathrm{e}+05$ & $3.00 e+03$ & $\mathrm{~d} / \mathrm{m} / \mathrm{g}$ Fuel & $09 / 14 / 88$ \\
\hline 104 & MKP070 & $\mathrm{L}$ & $88-55$ & B71989-F-8 & $\begin{array}{l}{ }^{137} \mathrm{Cs} \text { on Cladding } \\
\text { Interior }\end{array}$ & $2.960 e+08$ & $1.10 \mathrm{e}+07$ & $\mathrm{~d} / \mathrm{m} / \mathrm{cm} 2$ & $09 / 28 / 88$ \\
\hline 104 & MKP070 & $\mathbf{L}$ & $88-55$ & B71989-F-8 & $\begin{array}{l}{ }^{135} \mathrm{Cs} \text { on Cladding } \\
\text { Interior }\end{array}$ & $1.370 \mathrm{e}+03$ & $1.90 e+02$ & $\mathrm{~d} / \mathrm{m} / \mathrm{cm} 2$ & $09 / 28 / 88$ \\
\hline 104 & MKP070 & L & $88-55$ & B71989-G-8 & $\begin{array}{l}129 \text { I on Cladding } \\
\text { Interior }\end{array}$ & $1.260 \mathrm{e}+02$ & $3.70 e+00$ & $\mathrm{~d} / \mathrm{m} / \mathrm{cm} 2$ & $09 / 15 / 88$ \\
\hline 104 & MKP070 & M & $88-56$ & B71989-D-8 & ${ }^{14} \mathrm{C}$ in Fuel & $1.080 \mathrm{e}-06$ & $1.10 \mathrm{e}-07$ & $\mathrm{Ci} / \mathrm{g}$ Fuel & \\
\hline 104 & MKP070 & M & $88-56$ & B71989-D-8 & ${ }^{14} \mathrm{C}$ in Fuel & $1.051 \mathrm{e}-06$ & $1.10 \mathrm{e}-07$ & $\mathrm{Ci} / \mathrm{g}$ Fuel & \\
\hline 104 & MKP070 & M & $88-56$ & B71989-E-8 & ${ }^{14} \mathrm{C}$ in Cladding & $3.960 \mathrm{e}-07$ & $4.00 \mathrm{e}-08$ & $\mathrm{Ci} / \mathrm{g} \mathrm{Zr}$ & \\
\hline
\end{tabular}


Table B.1. (contd)

\begin{tabular}{|c|c|c|c|c|c|c|c|c|c|}
\hline ATM & Rod & Section & $\begin{array}{l}\text { Sample } \\
\text { Number }\end{array}$ & $\begin{array}{l}\text { Analytical } \\
\text { Request }\end{array}$ & Type of Analysis & Measured Value & Uncertainties & $\begin{array}{c}\text { Measured } \\
\text { Value Units }\end{array}$ & $\begin{array}{c}\text { Date } \\
\text { Measured }\end{array}$ \\
\hline 104 &. $\mathrm{MKP} 070$ & $\mathrm{M}$ & $88-56$ & B71989-E-8 & ${ }^{14} \mathrm{C}$ in Cladding & $9.400 \mathrm{e}-07$ & $9.40 \mathrm{e}-08$ & $\mathrm{Ci} / \mathrm{g} \mathrm{Zr}$ & \\
\hline 104 & MKP070 & o & $88-57$ & B71989-F-8 & $\begin{array}{l}{ }^{137} \mathrm{Cs} \text { on Cladding } \\
\text { Interior }\end{array}$ & $3.300 e+08$ & $1.30 e+07$ & $\mathrm{~d} / \mathrm{m} / \mathrm{cm} 2$ & $09 / 28 / 88$ \\
\hline 104 & MKP070 & o & $88-57$ & B71989-F-8 & $\begin{array}{l}{ }^{135} \mathrm{Cs} \text { on Cladding } \\
\text { Interior }\end{array}$ & $1.500 e+03$ & $2.10 e+02$ & $\mathrm{~d} / \mathrm{m} / \mathrm{cm} 2$ & $09 / 28 / 88$ \\
\hline 104 & MKP070 & o & $88-57$ & B71989-G-8 & $\begin{array}{l}129 \text { I on Cladding } \\
\text { Interior }\end{array}$ & $1.390 \mathrm{e}+02$ & $4.00 e+00$ & $\mathrm{~d} / \mathrm{m} / \mathrm{cm} 2$ & $09 / 15 / 88$ \\
\hline 104 & MKP070 & $\mathbf{P}$ & $88-58$ & B71989-D-8 & ${ }^{14} \mathrm{C}$ in Fuel & $1.076 \mathrm{e}-06$ & $1.10 \mathrm{e}-07$ & $\mathrm{Ci} / \mathrm{g}$ Fuel & \\
\hline 104 & MKP070 & $\mathbf{P}$ & $88-58$ & B71989-D-8 & ${ }^{14} \mathrm{C}$ in Fuel & $1.163 \mathrm{e}-06$ & $1.20 \mathrm{e}-07$ & Ci/g Fuel & \\
\hline 104 & MKP070 & $\mathbf{P}$ & $88-58$ & B71989-E-8 & ${ }^{14} \mathrm{C}$ in Cladding & $1.006 \mathrm{e}-06$ & $1.00 \mathrm{e}-07$ & $\mathrm{Ci} / \mathrm{g} \mathrm{Zr}$ & \\
\hline 104 & MKP070 & $\mathbf{P}$ & $88-58$ & B71989-E-8 & ${ }^{14} \mathrm{C}$ in Cladding & $9.520 \mathrm{e}-07$ & $9.50 \mathrm{e}-08$ & $\mathrm{Ci} / \mathrm{g} \mathrm{Zr}$ & \\
\hline 104 & MKP070 & $\mathbf{R}$ & $88-59$ & B71989-B-8 & $\begin{array}{l}\text { Measured Fuel } \\
\text { Burnup }\end{array}$ & $2.496 e+01$ & & $\mathrm{MWd} / \mathrm{kgM}$ & \\
\hline 104 & MKP070 & $\mathbf{R}$ & $88-59$ & B71989-B-8 & ${ }^{234} \mathrm{U}$ & $1.900 \mathrm{e}-02$ & $2.00 \mathrm{e}-03$ & ${ }^{234} \mathrm{U} w t \%$ & \\
\hline 104 & MKP070 & $\mathbf{R}$ & $88-59$ & B71989-B-8 & ${ }^{235} \mathrm{U}$ & $1.088 e+00$ & $8.00 \mathrm{e}-03$ & ${ }^{235} \mathrm{U}$ wt \% & \\
\hline 104 & MKP070 & $\mathbf{R}$ & $88-59$ & B71989-B-8 & ${ }^{236} \mathrm{U}$ & $3.540 \mathrm{e}-01$ & $6.00 \mathrm{e}-03$ & ${ }^{236} \mathrm{U}$ wt\% & \\
\hline 104 & MKP070 & $\mathbf{R}$ & $88-59$ & B71989-B-8 & ${ }^{238} \mathrm{U}$ & $9.854 e+01$ & $2.00 \mathrm{e}-02$ & ${ }^{238} \mathrm{U} w \mathrm{t} \%$ & \\
\hline 104 & MKP070 & $\mathbf{R}$ & $88-59$ & B71989-B-8 & ${ }^{238} \mathrm{Pu}$ & $1.239 e+00$ & $2.00 \mathrm{e}-02$ & ${ }^{238} \mathrm{Pu}$ wt\% & \\
\hline 104 & MKP070 & $\mathbf{R}$ & $88-59$ & B71989-B-8 & ${ }^{239} \mathrm{Pu}$ & $6.290 \mathrm{e}+01$ & $1.50 \mathrm{e}-01$ & ${ }^{239} \mathrm{Pu}$ wt $\%$ & \\
\hline 104 & MKP070 & $\mathbf{R}$ & $88-59$ & B71989-B-8 & ${ }^{240} \mathrm{Pu}$ & $2.363 e+01$ & $1.50 \mathrm{e}-01$ & ${ }^{240} \mathrm{Pu} w \mathrm{wt} \%$ & \\
\hline 104 & MKP070 & $\mathbf{R}$ & $88-59$ & B71989-B-8 & ${ }^{241} \mathrm{Pu}$ & $8.709 e+00$ & $8.00 \mathrm{e}-02$ & ${ }^{241} \mathrm{Pu}$ wt $\%$ & \\
\hline 104 & MKP070 & $\mathrm{R}$ & $88-59$ & B71989-B-8 & ${ }^{242} \mathrm{Pu}$ & $3.521 e+00$ & $3.00 \mathrm{e}-02$ & ${ }^{242} \mathrm{Pu} w \mathrm{wt} \%$ & \\
\hline 104 & MKP070 & $\mathbf{R}$ & $88-59$ & B71989-B-8 & ${ }^{79} \mathrm{Se}$ & $9.300 e+04$ & $4.90 \mathrm{e}+03$ & $\mathrm{~d} / \mathrm{m} / \mathrm{g}$ fuel & $9 / 23 / 88$ \\
\hline
\end{tabular}


Table B.1. (contd)

\begin{tabular}{|c|c|c|c|c|c|c|c|c|c|}
\hline ATM & Rod & Section & $\begin{array}{l}\text { Sample } \\
\text { Number }\end{array}$ & $\begin{array}{l}\text { Analytical } \\
\text { Request }\end{array}$ & Type of Analysis & Measured Value & Uncertainties & $\begin{array}{c}\text { Measured } \\
\text { Value Units }\end{array}$ & $\begin{array}{c}\text { Date } \\
\text { Measured }\end{array}$ \\
\hline 104 & MKP070 & $\mathbf{R}$ & $88-59$ & B71989-B-8 & ${ }^{90} \mathrm{Sr}$ & $5.730 e+10$ & $3.90 e+09$ & $\mathrm{~d} / \mathrm{m} / \mathrm{g}$ fuel & $09 / 21 / 88$ \\
\hline 104 & MKP070 & $\mathbf{R}$ & $88-59$ & B71989-B-8 & ${ }^{99} \mathrm{Tc}$ & $2.050 e+02$ & $9.60 e+00$ & $\mathrm{~d} / \mathrm{m} / \mathrm{g}$ fuel & $09 / 21 / 88$ \\
\hline 104 & MKP070 & $\mathbf{R}$ & $88-59$ & B71989-B-8 & ${ }^{126} \mathrm{Sn}$ & $1.950 e+05$ & $2.05 e+04$ & $\mathrm{~d} / \mathrm{m} / \mathrm{g}$ fuel & $09 / 20 / 88$ \\
\hline 104 & MKP070 & $\mathbf{R}$ & $.88-59$ & B71989-B-8 & ${ }^{135} \mathrm{Cs}$ & $8.740 e+05$ & $1.20 \mathrm{e}+05$ & $\mathrm{~d} / \mathrm{m} / \mathrm{g}$ fuel & $09 / 29 / 88$ \\
\hline 104 & MKP070 & $\mathbf{R}$ & $88-59$ & B71989-B-8 & ${ }^{137} \mathrm{Cs}$ & $1.300 e+11$ & $4.80 e+09$ & $\mathrm{~d} / \mathrm{m} / \mathrm{g}$ fuel & $09 / 29 / 88$ \\
\hline 104 & MKP070 & $\mathbf{R}$ & $88-59$ & B71989-B-8 & ${ }^{237} \mathrm{~Np}$ & $3.760 e+05$ & $1.10 \mathrm{e}+04$ & $\mathrm{~d} / \mathrm{m} / \mathrm{g}$ fuel & $09 / 20 / 88$ \\
\hline 104 & MKP070 & $\mathbf{R}$ & $88-59$ & B71,989-B-8 & ${ }^{241} \mathrm{Am}$ & $1.830 e+09$ & $2.20 e+07$ & $\mathrm{~d} / \mathrm{m} / \mathrm{g}$ fuel & $09 / 15 / 88$ \\
\hline 104 & MKP070 & $\mathbf{R}$ & $88-59$ & B71989-B-8 & $243 \&{ }^{244} \mathrm{Cm}$ & $9.850 e+08$ & $1.70 e+07$ & $\mathrm{~d} / \mathrm{m} / \mathrm{g}$ fuel & $09 / 15 / 88$ \\
\hline 104 & MKP070 & $\mathbf{R}$ & $88-59$ & & ${ }^{243} \mathrm{Am}$ in Fuel & $5.140 e+07$ & $1.90 e+07$ & $\mathrm{~d} / \mathrm{m} / \mathrm{g}$ Fuel & $09 / 15 / 88$ \\
\hline 104 & MKP070 & $\mathbf{R}$ & $88-59$ & & ${ }^{242} \mathrm{Cm}$ in Fuel & $1.980 \mathrm{e}+07$ & $1.05 e+06$ & $\mathrm{~d} / \mathrm{m} / \mathrm{g}$ Fuel & $09 / 15 / 88$ \\
\hline 104 & MKP070 & $\mathbf{R}$ & $88-59$ & & $\begin{array}{l}\text { Measured Fuel } \\
\text { Burnup }\end{array}$ & $2.496 e+04$ & & $\mathrm{MWd} / \mathrm{MTM}$ & \\
\hline 104 & MKP070 & $\mathbf{R}$ & $88-59$ & & ${ }^{143 / 148} \mathrm{Nd}$ & $2.437 e+00$ & & ${ }^{143 / 148} \mathrm{Nd}$ & \\
\hline 104 & MKP070 & $\mathbf{R}$ & $88-59$ & & ${ }^{144 / 148} \mathrm{Nd}$ & $3.586 e+00$ & & ${ }^{144 / 148} \mathrm{Nd}$ & \\
\hline 104 & MKP070 & $\mathbf{R}$ & $88-59$ & & $145 / 148 \mathrm{Nd}$ & $1.964 e+00$ & & ${ }^{145 / 148} \mathrm{Nd}$ & \\
\hline 104 & MKP070 & $\mathbf{R}$ & $88-59$ & & ${ }^{146 / 148} \mathrm{Nd}$ & $1.847 \mathrm{e}+00$ & & $146 / 148 \mathrm{Nd}$ & \\
\hline 104 & MKP070 & $\mathbf{R}$ & $88-59$ & & ${ }^{148} \mathrm{Nd}$ in Fuel & $9.919 e+17$ & & Atoms/g Fuel & \\
\hline 104 & MKP070 & $\mathbf{R}$ & $88-59$ & & ${ }^{150 / 148} \mathrm{Nd}$ & $4.596 \mathrm{e}-01$ & & ${ }^{150 / 148} \mathrm{Nd}$ & \\
\hline 104 & MKP070 & $\mathbf{s}$ & $88-60$ & B71989-C-8 & ${ }^{129} \mathrm{I}$ in Fuel & $4.900 \mathrm{e}+04$ & $1.40 \mathrm{e}+03$ & $\mathrm{~d} / \mathrm{m} / \mathrm{g}$ Fuel & $09 / 14 / 88$ \\
\hline 104 & MKP070 & s & $88-60$ & B71989-F-8 & $\begin{array}{l}{ }^{137} \mathrm{Cs} \text { on Cladding } \\
\text { Interior }\end{array}$ & $1.170 e+07$ & $4.40 \mathrm{e}+05$ & $\mathrm{~d} / \mathrm{m} / \mathrm{cm} 2$ & $09 / 28 / 88$ \\
\hline
\end{tabular}


Table B.1. (contd)

\begin{tabular}{|c|c|c|c|c|c|c|c|c|c|}
\hline ATM & Rod & Section & $\begin{array}{l}\text { Sample } \\
\text { Number }\end{array}$ & $\begin{array}{c}\text { Analytical } \\
\text { Request }\end{array}$ & Type of Analysis & Measured Value & Uncertainties & $\begin{array}{c}\text { Measured } \\
\text { Value Units }\end{array}$ & $\begin{array}{c}\text { Date } \\
\text { Measured }\end{array}$ \\
\hline 104 & MKP070 & $s$ & $88-60$ & B71989-F-8 & $\begin{array}{l}{ }^{135} \mathrm{Cs} \text { on Cladding } \\
\text { Interior }\end{array}$ & $7.860 e+01$ & $1.30 \mathrm{e}+01$ & $\mathrm{~d} / \mathrm{m} / \mathrm{cm} 2$ & $09 / 28 / 88$ \\
\hline 104 & MKP070 & s & $88-60$ & B71989-G-8 & $\begin{array}{l}129 \text { I on Cladding } \\
\text { Interior }\end{array}$ & $7.800 e+00$ & $2.70 \mathrm{e}-01$ & $\mathrm{~d} / \mathrm{m} / \mathrm{cm} 2$ & $09 / 15 / 88$ \\
\hline 104 & MKP070 & $\mathrm{T}$ & $88-61$ & B71989-D-8 & ${ }^{14} \mathrm{C}$ in Fuel & $4.850 \mathrm{e}-07$ & $4.90 \mathrm{e}-08$ & $\mathrm{Ci} / \mathrm{g}$ Fuel & \\
\hline 104 & MKP070 & $\mathrm{T}$ & $88-61$ & B71989-D-8 & ${ }^{14} \mathrm{C}$ in Fuel & $4.470 \mathrm{e}-07$ & $4.50 \mathrm{e}-08$ & $\mathrm{Ci} / \mathrm{g}$ Fuel & \\
\hline 104 & MKP070 & $\mathrm{T}$ & $88-61$ & B71989-E-8 & ${ }^{14} \mathrm{C}$ in Cladding & $3.470 \mathrm{e}-07$ & $3.50 \mathrm{e}-08$ & $\mathrm{Ci} / \mathrm{g} \mathrm{Zr}$ & \\
\hline 104 & MKP070 & $\mathrm{T}$ & $88-61$ & B71989-E-8 & ${ }^{14} \mathrm{C}$ in Cladding & $3.180 \mathrm{e}-07$ & $3.20 \mathrm{e}-08$ & $\mathrm{Ci} / \mathrm{g} \mathrm{Zr}$ & \\
\hline 106 & NBD095 & $C \& D$ & $88-67 / 68$ & B71989-B-9 & $\begin{array}{l}\text { Measured Fuel } \\
\text { Burnup }\end{array}$ & $2.742 e+01$ & & $\mathrm{MWd} / \mathrm{kgM}$ & \\
\hline 106 & NBD095 & $C \& D$ & $88-67 / 68$ & B71989-B-9 & ${ }^{234} U$ & $1.200 \mathrm{e}-02$ & $1.00 \mathrm{e}-03$ & ${ }^{234} \mathrm{U} w \mathrm{t} \%$ & \\
\hline 106 & NBD095 & $C \& D$ & $88-67 / 68$ & B71989-B-9 & ${ }^{235} \mathrm{U}$ & $6.050 \mathrm{e}-01$ & $6.00 e-03$ & ${ }^{235} \mathrm{U} w t \%$ & \\
\hline 106 & NBD095. & $C \& D$ & $88-67 / 68$ & B71989-B-9 & ${ }^{236} \mathrm{U}$ & $3.240 \mathrm{e}-01$ & $3.00 \mathrm{e}-03$ & ${ }^{236} \mathrm{U} w t \%$ & \\
\hline 106 & NBD095 & $C \& D$ & $88-67 / 68$ & B71989-B-9 & ${ }^{238} \mathrm{U}$ & $9.906 \mathrm{e}+01$ & $9.00 \mathrm{e}-02$ & ${ }^{238} \mathrm{U}$ wt\% & \\
\hline 106 & NBD095 & $C \& D$ & $88-67 / 68$ & B71989-B-9 & ${ }^{238} \mathrm{Pu}$ & $1.644 \mathrm{e}+00$ & $2.00 \mathrm{e}-02$ & ${ }^{238} \mathrm{Pu}$ wt\% & \\
\hline 106 & NBD095 & $C \& D$ & $88-67 / 68$ & B71989-B-9 & ${ }^{239} \mathrm{Pu}$ & $5.726 e+01$ & $1.00 \mathrm{e}-01$ & ${ }^{239} \mathrm{Pu} w t \%$ & \\
\hline 106 & NBD095 & $C \& D$ & $88-67 / 68$ & B71989-B-9 & ${ }^{240} \mathrm{Pu}$ & $2.662 e+01$ & $1.00 \mathrm{e}-01$ & ${ }^{240} \mathrm{Pu} w t \%$ & \\
\hline 106 & NBD095 & $C \& D$ & $88-67 / 68$ & B71989-B-9 & ${ }^{241} \mathrm{Pu}$ & $8.815 e+00$ & $5.00 \mathrm{e}-02$ & ${ }^{241} \mathrm{Pu}$ wt\% & \\
\hline 106 & NBD095 & $C \& D$ & $88-67 / 68$ & B71989-B-9 & ${ }^{242} \mathrm{Pu}$ & $5.665 e+00$ & $3.00 \mathrm{e}-02$ & ${ }^{242} \mathrm{Pu} w t \%$ & \\
\hline 106 & NBD095 & $C \& D$ & $88-67 / 68$ & B71989-B-9 & ${ }^{79} \mathrm{Se}$ & $1.080 e+05$ & $8.50 \mathrm{e}+03$ & $\mathrm{~d} / \mathrm{m} / \mathrm{g}$ fuel & $09 / 29 / 89$ \\
\hline 106 & NBD095 & $C \& D$ & $88-67 / 68$ & B71989-B-9 & ${ }^{90} \mathrm{Sr}$ & $9.170 e+10$ & $4.20 \mathrm{e}+09$ & $\mathrm{~d} / \mathrm{m} / \mathrm{g}$ fuel & $04 / 06 / 89$ \\
\hline 106 & NBD095 & $C \& D$ & $88-67 / 68$ & B71989-B-9 & ${ }^{99} \mathrm{Tc}$ & $2.040 e+07$ & $7.80 e+05$ & $\mathrm{~d} / \mathrm{m} / \mathrm{g}$ fuel & $04 / 03 / 89$ \\
\hline
\end{tabular}


Table B.1. (contd)

\begin{tabular}{|c|c|c|c|c|c|c|c|c|c|}
\hline ATM & Rod & Section & $\begin{array}{l}\text { Sample } \\
\text { Number }\end{array}$ & $\begin{array}{l}\text { Analytical } \\
\text { Request }\end{array}$ & Type of Analysis & Measured Value & Uncertainties & $\begin{array}{c}\text { Measured } \\
\text { Value Units }\end{array}$ & $\begin{array}{c}\text { Date } \\
\text { Measured }\end{array}$ \\
\hline 106 & NBD095 & $C \& D$ & $88-67 / 68$ & B71989-B-9 & ${ }^{126} \mathrm{Sn}$ & $7.900 e+05$ & $4.00 e+04$ & $\mathrm{~d} / \mathrm{m} / \mathrm{g}$ fuel & $04 / 04 / 89$ \\
\hline 106 & NBD095 & $C \& D$ & $88-67 / 68$ & B71989-B-9 & ${ }^{135} \mathrm{Cs}$ & $8.820 e+05$ & $1.30 \mathrm{e}+05$ & $\mathrm{~d} / \mathrm{m} / \mathrm{g}$ fuel & $04 / 10 / 89$ \\
\hline 106 & NBD095 & C \& D & $88-67 / 68$ & B71989-B-9 & ${ }^{137} \mathrm{Cs}$ & $1.420 \mathrm{e}+11$ & $6.00 e+09$ & $\mathrm{~d} / \mathrm{m} / \mathrm{g}$ fuel & $04 / 10 / 89$ \\
\hline 106 & NBD095 & $C \& D$ & $88-67 / 68$ & В71989-B-9 & ${ }^{237} \mathrm{~Np}$ & $4.460 \mathrm{e}+05$ & $3.20 \mathrm{e}+04$ & $\mathrm{~d} / \mathrm{m} / \mathrm{g}$ fuel & $09 / 19 / 89$ \\
\hline 106 & NBD095 & $C \& D$ & $88-67 / 68$ & B71989-B-9 & ${ }^{241} \mathrm{Am}$ & $2.790 e+09$ & $1.70 \mathrm{e}+08$ & $\mathrm{~d} / \mathrm{m} / \mathrm{g}$ fuel & $04 / 27 / 89$ \\
\hline 106 & NBD095 & $C \& D$ & $88-67 / 68$ & B71989-B-9 & ${ }^{243} \&{ }^{244} \mathrm{Cm}$ & $2.470 e+09$ & $1.50 \mathrm{e}+08$ & $\mathrm{~d} / \mathrm{m} / \mathrm{g}$ fuel & $04 / 27 / 89$ \\
\hline 106 & NBD095 & $C \& D$ & $88-67 / 68$ & B71989-B-9 & ${ }^{242} \mathrm{Cm}$ in Fuel & $2.400 e+07$ & $1.90 e+06$ & $\mathrm{~d} / \mathrm{m} / \mathrm{g}$ Fuel & $08 / 27 / 89$ \\
\hline 106 & NBD095 & $C \& D$ & $88-67 / 68$ & B71989-B-9 & $\begin{array}{l}\text { Measured Fuel } \\
\text { Burnup }\end{array}$ & $2.742 e+04$ & & $\mathrm{MWd} / \mathrm{MTM}$ & $04 / 15 / 89$ \\
\hline 106 & NBD095 & $C \& D$ & $88-67 / 68$ & B71989-B-9 & $143 / 148 \mathrm{Nd}$ & $2.169 e+00$ & & ${ }^{143 / 148} \mathrm{Nd}$ & $04 / 15 / 89$ \\
\hline 106 & NBD095 & $C \& D$ & $88-67 / 68$ & B71989-B-9 & ${ }^{144 / 148} \mathrm{Nd}$ & $3.723 e+00$ & & ${ }^{144 / 148} \mathrm{Nd}$ & $04 / 15 / 89$ \\
\hline 106 & NBD095 & $C \& D$ & $88-67 / 68$ & B71989-B-9 & ${ }^{145 / 148} \mathrm{Nd}$ & $1.891 e+00$ & & ${ }^{145 / 148} \mathrm{Nd}$ & $04 / 15 / 89$ \\
\hline 106 & NBD095 & $C \& D$ & $88-67 / 68$ & B71989-B-9 & ${ }^{146 / 148} \mathrm{Nd}$ & $1.863 \mathrm{e}+00$ & & ${ }^{146 / 148} \mathrm{Nd}$ & $04 / 15 / 89$ \\
\hline 106 & NBD095 & C \& D & $88-67 / 68$ & B71989-B-9 & ${ }^{148} \mathrm{Nd}$ in Fuel & $1.093 e+18$ & & Atoms/g Fuel & $04 / 15 / 89$ \\
\hline 106 & NBD095 & $C \& D$ & $88-67 / 68$ & B71989-B-9 & ${ }^{150 / 148} \mathrm{Nd}$ & $4.734 \mathrm{e}-01$ & & ${ }^{150 / 148} \mathrm{Nd}$ & $04 / 15 / 89$ \\
\hline 106 & NBD095 & F & $88-70$ & B71989-F-9 & $\begin{array}{l}{ }^{137} \mathrm{Cs} \text { on Cladding } \\
\text { Interior }\end{array}$ & $2.120 \mathrm{e}+07$ & $8.70 e+05$ & $\mathrm{~d} / \mathrm{m} / \mathrm{cm} 2$ & $04 / 25 / 89$ \\
\hline 106 & NBD095 & F & $88-70$ & B71989-F-9 & $\begin{array}{l}{ }^{135} \mathrm{Cs} \text { on Cladding } \\
\text { Interior }\end{array}$ & $1.180 \mathrm{e}+02$ & $1.69 \mathrm{e}+01$ & $\mathrm{~d} / \mathrm{m} / \mathrm{cm} 2$ & $04 / 25 / 89$ \\
\hline 106 & NBD095 & $\mathrm{F}$ & $88-70$ & B71989-G-9 & $\begin{array}{l}{ }^{129} \text { I on Cladding } \\
\text { Interior }\end{array}$ & $2.990 e+02$ & $1.40 e+01$ & $\mathrm{~d} / \mathrm{m} / \mathrm{cm} 2$ & $08 / 31 / 89$ \\
\hline 106 & NBD095 & H & $88-72$ & B71989-D-9 & ${ }^{14} \mathrm{C}$ in Fuel & $8.690 \mathrm{e}-07$ & $8.70 \mathrm{e}-08$ & $\mathrm{Ci} / \mathrm{g}$ fuel & \\
\hline 106 & NBD095 & H & $88-72$ & B71989-D-9 & ${ }^{14} \mathrm{C}$ in Fuel & $7.400 \mathrm{e}-07$ & $7.40 \mathrm{e}-08$ & $\mathrm{Ci} / \mathrm{g}$ fuel & \\
\hline
\end{tabular}


Table B.1. (contd)

\begin{tabular}{|c|c|c|c|c|c|c|c|c|c|}
\hline ATM & Rod & Section & $\begin{array}{l}\text { Sample } \\
\text { Number }\end{array}$ & $\begin{array}{l}\text { Analytical } \\
\text { Request }\end{array}$ & Type of Analysis & Measured Value & Uncertainties & $\begin{array}{c}\text { Measured } \\
\text { Value Units }\end{array}$ & $\begin{array}{c}\text { Date } \\
\text { Measured }\end{array}$ \\
\hline 106 & NBD095 & $\mathrm{H}$ & $88-72$ & B71989-E-9 & ${ }^{14} \mathrm{C}$ in Cladding & $1.080 \mathrm{e}-06$ & $1.10 \mathrm{e}-07$ & $\mathrm{Ci} / \mathrm{g} \mathrm{Zr}$ & \\
\hline 106 & NBD095 & H & $88-72$ & B71989-E-9 & ${ }^{14} \mathrm{C}$ in Cladding & $9.830 \mathrm{e}-07$ & $9.80 \mathrm{e}-07$ & $\mathrm{Ci} / \mathrm{g} \mathrm{Zr}$ & \\
\hline 106 & NBD095 & K & $88-74$ & B71989-F-9 & $\begin{array}{l}{ }^{137} \mathrm{Cs} \text { on Cladding } \\
\text { Interior }\end{array}$ & $6.610 e+07$ & $2.64 e+06$ & $\mathrm{~d} / \mathrm{m} / \mathrm{cm} 2$ & $04 / 25 / 89$ \\
\hline 106 & NBD095 & K & $88-74$ & B71989-F-9 & $\begin{array}{l}{ }^{135} \mathrm{Cs} \text { on Cladding } \\
\text { Interior }\end{array}$ & $3.050 \mathrm{e}+02$ & $4.39 \mathrm{e}+01$ & $\mathrm{~d} / \mathrm{m} / \mathrm{cm} 2$ & $04 / 25 / 89$ \\
\hline 106 & NBD095 & K & $88-74$ & B71989-G-9 & $\begin{array}{l}129 \text { I on Cladding } \\
\text { Interior }\end{array}$ & $1.010 \mathrm{e}+03$ & $5.10 e+01$ & $\mathrm{~d} / \mathrm{m} / \mathrm{cm} 2$ & $08 / 31 / 89$ \\
\hline 106 & NBD095 & $\mathrm{N}$ & $88-76$ & B71989-F-9 & $\begin{array}{l}{ }^{137} \mathrm{Cs} \text { on Cladding } \\
\text { Interior }\end{array}$ & $2.890 e+08$ & $1.10 e+07$ & $\mathrm{~d} / \mathrm{m} / \mathrm{cm} 2$ & $04 / 25 / 89$ \\
\hline 106 & NBD095 & $N$ & $88-76$ & B71989-F-9 & $\begin{array}{l}{ }^{135} \mathrm{Cs} \text { on Cladding } \\
\text { Interior }\end{array}$ & $1.310 e+03$ & $1.82 \mathrm{e}+02$ & $\mathrm{~d} / \mathrm{m} / \mathrm{cm} 2$ & $04 / 25 / 89$ \\
\hline 106 & NBD095 & $\mathrm{N}$ & $88-76$ & B71989-G-9 & $\begin{array}{l}{ }^{129} \text { I on Cladding } \\
\text { Interior }\end{array}$ & $1.300 \mathrm{e}+03$ & $5.20 \mathrm{e}+01$ & $\mathrm{~d} / \mathrm{m} / \mathrm{cm} 2$ & 09/07/89 \\
\hline 106 & NBD095 & $\mathbf{P}$ & $88-78$ & B71989-D-9 & ${ }^{14} \mathrm{C}$ in fuel & $1.400 \mathrm{e}-06$ & $1.40 \mathrm{e}-07$ & Ci/g Fuel & \\
\hline 106 & NBD095 & $\mathbf{P}$ & $88-78$ & B71989-D-9 & ${ }^{14} \mathrm{C}$ in Fuel & $1.420 \mathrm{e}-06$ & $1.40 \mathrm{e}-07$ & $\mathrm{Ci} / \mathrm{g}$ fuel & \\
\hline 106 & NBD095 & $\mathbf{P}$ & $88-78$ & B71989-E-9 & ${ }^{14} \mathrm{C}$ in Cladding & $1.560 \mathrm{e}-06$ & $1.60 \mathrm{e}-07$ & $\mathrm{Ci} / \mathrm{g}$ fuel & \\
\hline 106 & NBD095 & $\mathbf{P}$ & $88-78$ & B71989-E-9 & ${ }^{14} \mathrm{C}$ in cladding & $1.480 \mathrm{e}-06$ & $1.50 \mathrm{e}-07$ & $\mathrm{Ci} / \mathrm{g} \mathrm{Zr}$ & \\
\hline 106 & NBD095 & $X \& Y$ & $88-85 / 86$ & B71989-B-9 & $\begin{array}{l}\text { Measured Fuel } \\
\text { Burnup }\end{array}$ & $4.675 e+01$ & & $\mathrm{MWd} / \mathrm{kgM}$ & \\
\hline 106 & NBD095 & $X \& Y$ & $88-85 / 86$ & B71989-B-9 & ${ }^{234} \mathrm{U}$ & $1.000 \mathrm{e}-02$ & $1.00 \mathrm{e}-03$ & ${ }^{234} \mathrm{U} w t \%$ & \\
\hline 106 & NBD095 & $X \& Y$ & $88-85 / 86$ & B71989-B-9 & ${ }^{235} \mathrm{U}$ & $1.540 \mathrm{e}-01$ & $2.00 \mathrm{e}-03$ & ${ }^{235} \mathrm{U}$ wt\% & \\
\hline 106 & NBD095 & $X \& Y$ & $88-85 / 86$ & B71989-B-9 & ${ }^{236} \mathrm{U}$ & $3.660 \mathrm{e}-01$ & $4.00 \mathrm{e}-03$ & ${ }^{236} U$ wt \% & \\
\hline 106 & NBD095 & $X \& Y$ & $88-85 / 86$ & B71989-B-9 & ${ }^{238} \mathrm{U}$ & $9.947 e+01$ & $9.00 \mathrm{e}-02$ & ${ }^{238} \mathrm{U}$ wt\% & \\
\hline
\end{tabular}


Table B.1. (contd)

\begin{tabular}{|c|c|c|c|c|c|c|c|c|c|}
\hline ATM & Rod & Section & $\begin{array}{c}\text { Sample } \\
\text { Number }\end{array}$ & $\begin{array}{c}\text { Analytical } \\
\text { Request }\end{array}$ & Type of Analysis & Measured Value & Uncertainties & $\begin{array}{c}\text { Measured } \\
\text { Value Units }\end{array}$ & $\begin{array}{c}\text { Date } \\
\text { Measured }\end{array}$ \\
\hline 106 & NBD095 & $X \& Y$ & $88-85 / 86$ & B71989-B-9 & ${ }^{238} \mathrm{Pu}$ & $3.290 e+00$ & $2.00 \mathrm{e}-02$ & ${ }^{238} \mathrm{Pu} w \mathrm{t} \%$ & \\
\hline 106 & NBD095 & $X \& Y$ & $88-85 / 86$ & B71989-B-9 & ${ }^{239} \mathrm{Pu}$ & $4.331 e+01$ & $1.00 \mathrm{e}-01$ & ${ }^{239} \mathrm{Pu} w t \%$ & \\
\hline 106 & NBD095 & $X \& Y$ & $88-85 / 86$ & B71989-B-9 & ${ }^{240} \mathrm{Pu}$ & $3.021 e+01$ & $1.00 \mathrm{e}-01$ & ${ }^{240} \mathrm{Pu} w t \%$ & \\
\hline 106 & NBD095 & $X \& Y$ & $88-85 / 86$ & B71989-B-9 & ${ }^{241} \mathrm{Pu}$ & $9.388 \mathrm{e}+00$ & $5.00 \mathrm{e}-02$ & ${ }^{241} \mathrm{Pu}$ wt\% & \\
\hline 106 & NBD095 & $X \& Y$ & $88-85 / 86$ & B71989-B-9 & ${ }^{242} \mathrm{Pu}$ & $1.380 e+01$ & $7.00 \mathrm{e}-02$ & ${ }^{242} \mathrm{Pu} w t \%$ & \\
\hline 106 & NBD095 & $X \& Y$ & $88-85 / 86$ & B71989-B-9 & ${ }^{79} \mathrm{Se}$ & $1.720 \mathrm{e}+05$ & $1.20 \mathrm{e}+04$ & $\mathrm{~d} / \mathrm{m} / \mathrm{g}$ fuel & 09/29/89 \\
\hline 106 & NBD095 & $X \& Y$ & $88-85 / 86$ & B71989-B-9 & ${ }^{90} \mathrm{Sr}$ & $1.310 \mathrm{e}+11$ & $5.80 e+09$ & $\mathrm{~d} / \mathrm{m} / \mathrm{g}$ fuel & $04 / 06 / 89$ \\
\hline 106 & NBD095 & $X \& Y$ & $88-85 / 86$ & B71989-B-9 & ${ }^{99} \mathrm{Tc}$ & $3.080 e+07$ & $9.90 \mathrm{e}+05$ & $\mathrm{~d} / \mathrm{m} / \mathrm{g}$ fuel & $04 / 03 / 89$ \\
\hline 106 & NBD095 & $X \& Y$ & $88-85 / 86$ & B71989-B-9 & ${ }^{126} \mathrm{Sn}$ & $7.660 e+05$ & $4.10 \mathrm{e}+04$ & $\mathrm{~d} / \mathrm{m} / \mathrm{g}$ fuel & 04/04/89 \\
\hline 106 & NBD095 & $X \& Y$ & $88-85 / 86$ & B71989-B-9 & ${ }^{135} \mathrm{Cs}$ & $1.060 \mathrm{e}+06$ & $1.45 \mathrm{e}+05$ & $\mathrm{~d} / \mathrm{m} / \mathrm{g}$ fuel & $04 / 10 / 89$ \\
\hline 106 & NBD095 & $X \& Y$ & $88-85 / 86$ & B71989-B-9 & ${ }^{137} \mathrm{C}_{8}$ & $2.450 e+11$ & $1.10 \mathrm{e}+10$ & $\mathrm{~d} / \mathrm{m} / \mathrm{g}$ fuel & $04 / 10 / 89$ \\
\hline 106 & NBD095 & $X \& Y$ & $88-85 / 86$ & B71989-B-9 & ${ }^{237} \mathrm{~Np}$ & $7.100 e+05$ & $3.30 \mathrm{e}+04$ & $\mathrm{~d} / \mathrm{m} / \mathrm{g}$ fuel & $09 / 18 / 89$ \\
\hline 106 & NBD095 & $X \& Y$ & $88-85 / 86$ & B71989-B-9 & ${ }^{241} \mathrm{Am}$ & $3.640 e+09$ & & $\mathrm{~d} / \mathrm{m} / \mathrm{g}$ fuel & $04 / 27 / 89$ \\
\hline 106 & NBD095 & $X \& Y$ & $88-85 / 86$ & B71989-B-9 & ${ }^{243} \mathrm{Am}$ & $2.4 \mathrm{E}+08$ & $5.28 \mathrm{E}+107$ & $\mathrm{~d} / \mathrm{m} / \mathrm{g}$ fuel & $04 / 27 / 89$ \\
\hline 106 & NBD095 & $X \& Y$ & $88-85 / 86$ & B71989-B-9 & $243 \& 244 \mathrm{Cm}$ & $2.210 e+10$ & $1.30 \mathrm{e}+09$ & $\mathrm{~d} / \mathrm{m} / \mathrm{g}$ fuel & $04 / 27 / 89$ \\
\hline 106 & NBD095 & $X \& Y$ & $88-85 / 86$ & B71989-B-9 & ${ }^{242} \mathrm{Cm}$ in Fuel & $3.100 e+08$ & $2.70 e+06$ & $\mathrm{~d} / \mathrm{m} / \mathrm{g}$ Fuel & $08 / 27 / 89$ \\
\hline 106 & NBD095 & $X \& Y$ & $88-85 / 86$ & B71989-B-9 & $\begin{array}{l}\text { Measured Fuel } \\
\text { Burnup }\end{array}$ & $4.675 \mathrm{e}+04$ & & $\mathrm{MWd} / \mathrm{MTM}$ & $04 / 15 / 89$ \\
\hline 106 & NBD095 & $X \& Y$ & $88-85 / 86$ & B71989-B-9 & ${ }^{143 / 148} \mathrm{Nd}$ & $1.428 \mathrm{e}+00$ & & ${ }^{143 / 148} \mathrm{Nd}$ & $04 / 15 / 89$ \\
\hline 106 & NBD095 & $X \& Y$ & $88-85 / 86$ & B71989-B-9 & $144 / 148 \mathrm{Nd}$ & $4.112 e+00$ & & ${ }^{144 / 148} \mathrm{Nd}$ & $04 / 15 / 89$ \\
\hline 106 & NBD095 & $X \& Y$ & $88-85 / 86$ & B71989-B-9 & $145 / 148 \mathrm{Nd}$ & $1.646 e+00$ & & ${ }^{145 / 148} \mathrm{Nd}$ & $04 / 15 / 89$ \\
\hline
\end{tabular}


Table B.1. (contd)

\begin{tabular}{|c|c|c|c|c|c|c|c|c|c|}
\hline ATM & Rod & Section & $\begin{array}{c}\text { Sample } \\
\text { Number }\end{array}$ & $\begin{array}{c}\text { Analytical } \\
\text { Request }\end{array}$ & Type of Analysis & Measured Value & Uncertainties & $\begin{array}{c}\text { Measured } \\
\text { Value Units }\end{array}$ & $\begin{array}{c}\text { Date } \\
\text { Measured }\end{array}$ \\
\hline 106 & NBD095 & $X \& Y$ & $88-85 / 86$ & B71989-B-9 & ${ }^{146 / 148} \mathrm{Nd}$ & $1.971 \mathrm{e}+00$ & & ${ }^{146 / 148} \mathrm{Nd}$ & $04 / 15 / 89$ \\
\hline 106 & NBD095 & $X \& Y$ & $88-85 / 86$ & B71989-B-9 & ${ }^{148} \mathrm{Nd}$ in Fuel & $1.849 e+18$ & $\therefore$ & Atoms/g Fuel & $04 / 15 / 89$ \\
\hline 106 & NBD095 & $X \& Y$ & $88-85 / 86$ & B71989-B-9 & ${ }^{150 / 148} \mathrm{Nd}$ & $4.953 \mathrm{e}-01$ & $\therefore$ & $150 / 148 \mathrm{Nd}$ & $04 / 15 / 89$ \\
\hline 106 & NBD095 & $\mathrm{AA}$ & $88-88$ & B71989-F-9 & $\begin{array}{l}{ }^{137} \mathrm{Cs} \text { on Cladding } \\
\text { Interior }\end{array}$ & $8.570 e+08$ & $3.30 \mathrm{e}+07$ & $\mathrm{~d} / \mathrm{m} / \mathrm{cm} 2$ & $04 / 24 / 89$ \\
\hline 106 & NBD095 & $\mathrm{AA}$ & $88-88$ & B71989-F-9 & $\begin{array}{l}{ }^{135} \mathrm{Cs} \text { on Cladding } \\
\text { Interior }\end{array}$ & $3.830 \mathrm{e}+03$ & $5.44 e+02$ & $\mathrm{~d} / \mathrm{m} / \mathrm{cm} 2$ & $04 / 24 / 89$ \\
\hline 106 & NBD095 & $\mathrm{AA}$ & $88-88$ & B71989-G-9 & $\begin{array}{l}129 \text { I on Cladding } \\
\text { Interior }\end{array}$ & $2.500 e+03$ & $1.20 \mathrm{e}+02$ & $\mathrm{~d} / \mathrm{m} / \mathrm{cm} 2$ & $09 / 07 / 89$ \\
\hline 106 & NBD095 & FF & $88-92$ & B71989-F-9 & $\begin{array}{l}{ }^{137} \mathrm{Cs} \text { on Cladding } \\
\text { Interior }\end{array}$ & $2.480 e+09$ & $1.00 \mathrm{e}+08$ & $\mathrm{~d} / \mathrm{m} / \mathrm{cm} 2$ & $04 / 24 / 89$ \\
\hline 106 & NBD095 & FF & $88-92$ & B71989-F-9 & $\begin{array}{l}{ }^{135} \mathrm{Cs} \text { on Cladding } \\
\text { Interior }\end{array}$ & $1.180 e+04$ & $1.68 \mathrm{e}+03$ & $\mathrm{~d} / \mathrm{m} / \mathrm{cm} 2$ & $04 / 24 / 89$ \\
\hline 106 & NBD095 & $\mathrm{FF}$ & $88-92$ & B71989-G-9 & $\begin{array}{l}{ }^{129} \text { I on Cladding } \\
\text { Interior }\end{array}$ & $3.230 \mathrm{e}+04$ & $1.40 \mathrm{e}+03$ & $\mathrm{~d} / \mathrm{m} / \mathrm{cm} 2$ & $09 / 07 / 89$ \\
\hline 106 & NBD095 & $\mathrm{HH}$ & $88-94$ & B71989-D-9 & ${ }^{14} \mathrm{C}$ in Fuel & $1.440 \mathrm{e}-06$ & $1.40 \mathrm{e}-07$ & $\mathrm{Ci} / \mathrm{g}$ fuel & \\
\hline 106 & NBD095 & HH & $88-94$ & B71989-D-9 & ${ }^{14} \mathrm{C}$ in Fuel & $1.640 \mathrm{e}-06$ & $1.60 \mathrm{e}-07$ & $\mathrm{Ci} / \mathrm{g}$ fuel & \\
\hline 106 & NBD095 & $\mathrm{HH}$ & $88-94$ & B71989-E-9 & ${ }^{14} \mathrm{C}$ in Cladding & $2.080 \mathrm{e}-06$ & $2.10 \mathrm{e}-07$ & $\mathrm{Ci} / \mathrm{g} \mathrm{Zr}$ & \\
\hline 106 & NBD095 & HH & $88-94$ & B71989-E-9 & ${ }^{14} \mathrm{C}$ in Cladding & $2.300 \mathrm{e}-06$ & $2.30 \mathrm{e}-07$ & $\mathrm{Ci} / \mathrm{g}$ fuel & \\
\hline 106 & NBD095 & $\mathrm{LL}$ & $88-97$ & B71989-B-9A & ${ }^{135} \mathrm{Cs}$ in Fuel & $9.800 e+05$ & $1.39 e+05$ & $\mathrm{~d} / \mathrm{m} / \mathrm{g}$ fuel & $04 / 11 / 89$ \\
\hline 106 & NBD095 & LL & $88-97$ & B71989-B-9A & ${ }^{137} \mathrm{Cs}$ in Fuel & $2.270 \mathrm{e}+11$ & $8.90 \mathrm{e}+09$ & $\mathrm{~d} / \mathrm{m} / \mathrm{g}$ fuel & $04 / 11 / 89$ \\
\hline 106 & NBD095 & MM & $88-98$ & B71989-F-9 & $\begin{array}{l}{ }^{137} \mathrm{Cs} \text { on Cladding } \\
\text { Interior }\end{array}$ & $6.310 e+09$ & $2.70 e+08$ & $\mathrm{~d} / \mathrm{m} / \mathrm{cm} 2$ & $04 / 24 / 89$ \\
\hline
\end{tabular}


Table B.1. (contd)

\begin{tabular}{|c|c|c|c|c|c|c|c|c|c|}
\hline ATM & Rod & Section & $\begin{array}{l}\text { Sample } \\
\text { Number }\end{array}$ & $\begin{array}{l}\text { Analytical } \\
\text { Request }\end{array}$ & Type of Analysis & Measured Value & Uncertainties & $\begin{array}{c}\text { Measured } \\
\text { Value Units }\end{array}$ & $\begin{array}{c}\text { Date } \\
\text { Measured }\end{array}$ \\
\hline 106 & NBD095 & MM & 88-98 & B71989-F-9 & $\begin{array}{l}{ }^{135} \mathrm{Cs} \text { on Cladding } \\
\text { Interior }\end{array}$ & $2.950 e+04$ & $4.07 e+03$ & $\mathrm{~d} / \mathrm{m} / \mathrm{cm} 2$ & $04 / 24 / 89$ \\
\hline 106 & NBD095 & $\mathrm{MM}$ & 88-98 & B71989-G-9 & $\begin{array}{l}129 \text { I on Cladding } \\
\text { Interior }\end{array}$ & $5.820 \mathrm{e}+04$ & $3.80 e+03$ & $\mathrm{~d} / \mathrm{m} / \mathrm{cm} 2$ & $09 / 08 / 89$ \\
\hline 106 & NBD095 & PP & $88-101$ & B71989-D-9 & ${ }^{14} \mathrm{C}$ in Fuel & $1.150 \mathrm{e}-06$ & $1.20 \mathrm{e}-07$ & $\mathrm{Ci} / \mathrm{g}$ fuel & \\
\hline 106 & NBD095 & PP & $88-101$ & B71989-D-9 & ${ }^{14} \mathrm{C}$ in Fuel & $1.420 \mathrm{e}-06$ & $1.40 \mathrm{e}-07$ & $\mathrm{Ci} / \mathrm{g}$ fuel & \\
\hline 106 & NBD095 & PP & $88-101$ & B71989-E-9 & ${ }^{14} \mathrm{C}$ in Cladding & $1.820 \mathrm{e}-06$ & $1.80 \mathrm{e}-07$ & $\mathrm{Ci} / \mathrm{g} \mathrm{Zr}$ & \\
\hline 106 & NBD095 & PP & 88-101 & B71989-E-9 & ${ }^{14} \mathrm{C}$ in Cladding & $2.100 \mathrm{e}-06$ & $2.10 \mathrm{e}-07$ & $\mathrm{Ci} / \mathrm{g} \mathrm{Zr}$ & \\
\hline 106 & NBD095 & $\mathrm{xx}$ & $88-108$ & B71989-F-9 & $\begin{array}{l}{ }^{137} \mathrm{Cs} \text { on Cladding } \\
\text { Interior }\end{array}$ & $1.050 e+10$ & $4.00 e+08$ & $\mathrm{~d} / \mathrm{m} / \mathrm{cm} 2$ & $04 / 24 / 89$ \\
\hline 106 & NBD095 & $\mathrm{xx}$ & $88-108$ & .B71989-F-9 & $\begin{array}{l}{ }^{135} \mathrm{Cs} \text { on Cladding } \\
\text { Interior } \\
\end{array}$ & $5.030 e+04$ & $6.89 e+03$ & $\mathrm{~d} / \mathrm{m} / \mathrm{cm} 2$ & $04 / 24 / 89$ \\
\hline 106 & NBD095 & $x x$ & $88-108$ & B71989-G-9 & $\begin{array}{l}129 \text { I on Cladding } \\
\text { Interior }\end{array}$ & $8.530 e+04$ & $4.60 \mathrm{e}+03$ & $\mathrm{~d} / \mathrm{m} / \mathrm{cm} 2$ & $09 / 08 / 89$ \\
\hline 106 & NBD095 & $\mathrm{CCC}$ & $88-112$ & B71989-F-9 & $\begin{array}{l}{ }^{137} \mathrm{Cs} \text { on Cladding } \\
\text { Interior }\end{array}$ & $1.150 e+10$ & $4.90 \mathrm{e}+08$ & $\mathrm{~d} / \mathrm{m} / \mathrm{cm} 2$ & $04 / 24 / 89$ \\
\hline 106 & NBD095 & $\mathrm{CCC}$ & $88-112$ & B71989-F-9 & $\begin{array}{l}{ }^{135} \mathrm{Cs} \text { on Cladding } \\
\text { Interior } \\
\end{array}$ & $7.270 e+04$ & $1.05 e+04$ & $\mathrm{~d} / \mathrm{m} / \mathrm{cm} 2$ & $04 / 24 / 89$ \\
\hline 106 & NBD095 & $\mathrm{CCC}$ & $88-112$ & B71989-G-9 & $\begin{array}{l}129 \text { I on Cladding } \\
\text { Interior }\end{array}$ & $1.870 \mathrm{e}+04$ & $1.10 \mathrm{e}+03$ & $\mathrm{~d} / \dot{\mathrm{m}} / \mathrm{cm} 2$ & $09 / 08 / 89$ \\
\hline 106 & NBD095 & EEE & $88-114$ & B71989-D-9 & ${ }^{14} \mathrm{C}$ in Fuel & $5.550 \mathrm{e}-07$ & $5.60 \mathrm{e}-08$ & $\mathrm{Ci} / \mathrm{g}$ fuel & \\
\hline 106 & NBD095 & EEE & $88-114$ & B71989-D-9 & ${ }^{14} \mathrm{C}$ in Fuel & $5.740 \mathrm{e}-07$ & $.5 .70 \mathrm{e}-08$ & $\mathrm{Ci} / \mathrm{g}$ fuel & \\
\hline 106 & NBD095 & EEE & $88-114$ & B71989-E-9 & ${ }^{14} \mathrm{C}$ in Cladding & $8.280 \mathrm{e}-07$ & $8.30 \mathrm{e}-08$ & $\mathrm{Ci} / \mathrm{g}$ fuel & \\
\hline 106 & NBD095 & EEE & $88-114$ & B71989-E-9 & ${ }^{14} \mathrm{C}$ in Cladding & $1.150 \mathrm{e}-06$ & $1.20 \mathrm{e}-07$ & $\mathrm{Ci} / \mathrm{g} \mathrm{Zr}$ & \\
\hline
\end{tabular}


Table B.1. (contd)

\begin{tabular}{|c|c|c|c|c|c|c|c|c|c|}
\hline ATM & Rod & Section & $\begin{array}{l}\text { Sample } \\
\text { Number }\end{array}$ & $\begin{array}{l}\text { Analytical } \\
\text { Request }\end{array}$ & Type of Analysis & Measured Value & Uncertainties & $\begin{array}{c}\text { Measured } \\
\text { Value Units }\end{array}$ & $\begin{array}{c}\text { Date } \\
\text { Measured }\end{array}$ \\
\hline 106 & NBD131 & C & $88-18$ & B71989-F-7 & $\begin{array}{l}{ }^{137} \mathrm{Cs} \text { on Cladding } \\
\text { Interior }\end{array}$ & $2.190 \mathrm{e}+10$ & $8.10 \mathrm{e}+08$ & $\mathrm{~d} / \mathrm{m} / \mathrm{cm} 2$ & $08 / 12 / 88$ \\
\hline 106 & NBD131 & C & $88-18$ & B71989-F-7 & $\begin{array}{l}{ }^{135} \mathrm{Cs} \text { on Cladding } \\
\text { Interior }\end{array}$ & $1.220 \mathrm{e}+05$ & $1.70 \mathrm{e}+04$ & $\mathrm{~d} / \mathrm{m} / \mathrm{cm} 2$ & $08 / 12 / 88$ \\
\hline 106 & NBD131 & $\mathrm{C}$ & $88-18$ & B71989-G-7 & $\begin{array}{l}129 \text { I on Cladding } \\
\text { Interior }\end{array}$ & $3.510 \mathrm{e}+04$ & $1.10 \mathrm{e}+03$ & $\mathrm{~d} / \mathrm{m} / \mathrm{cm} 2$ & $08 / 15 / 88$ \\
\hline 106 & NBD131 & D & $88-19$ & B71989-D-7 & ${ }^{14} \mathrm{C}$ in Fuel & $8.320 \mathrm{e}-07$ & $8.30 \mathrm{e}-08$ & $\mathrm{Ci} / \mathrm{g}$ fuel & \\
\hline 106 & NBD131 & D & 88-19 & B71989-D-7 & ${ }^{14} \mathrm{C}$ in Fuel & $9.170 \mathrm{e}-07$ & $9.20 \mathrm{e}-08$ & $\mathrm{Ci} / \mathrm{g}$ fuel & \\
\hline 106 & NBD131 & D & 88-19 & B71989-E-7 & ${ }^{14} \mathrm{C}$ in Cladding & $2.390 \mathrm{e}-06$ & $2.40 \mathrm{e}-07$ & $\mathrm{Ci} / \mathrm{g} \mathrm{Zr}$ & \\
\hline 106 & NBD131 & D & $88-19$ & B71989-E-7 & ${ }^{14} \mathrm{C}$ in Cladding & $2.540 \mathrm{e}-06$ & $2.50 \mathrm{e}-07$ & $\mathrm{Ci} / \mathrm{g} \mathrm{Zr}$ & \\
\hline 106 & NBD131 & $\mathrm{F}$ & $88-20$ & B71989-C-7 & ${ }^{129} \mathrm{I}$ in Fuel & $7.540 e+04$ & $5.70 \mathrm{e}+03$ & $d / m / g$ fuel & $08 / 19 / 88$ \\
\hline 106 & NBD131 & $F$ & $88-20$ & B71989-F-7 & $\begin{array}{l}{ }^{137} \mathrm{Cs} \text { on Cladding } \\
\text { Interior }\end{array}$ & $1.840 \mathrm{e}+10$ & $6.80 e+08$ & $\mathrm{~d} / \mathrm{m} / \mathrm{cm} 2$ & $08 / 12 / 88$ \\
\hline 106 & NBD131 & $\mathrm{F}$ & $88-20$ & B71989-F-7 & $\begin{array}{l}{ }^{135} \mathrm{Cs} \text { on Cladding } \\
\text { Interior }\end{array}$ & $8.360 e+04$ & $1.20 \mathrm{e}+04$ & $\mathrm{~d} / \mathrm{m} / \mathrm{cm} 2$ & $08 / 12 / 88$ \\
\hline 106 & NBD131 & $\mathbf{F}$ & $88-20$ & B71989-G-7 & $\begin{array}{l}129 \text { I on Cladding } \\
\text { Interior }\end{array}$ & $2.980 e+04$ & $8.90 \mathrm{e}+02$ & $\mathrm{~d} / \mathrm{m} / \mathrm{cm} 2$ & $08 / 15 / 88$ \\
\hline 106 & NBD131 & J & $88-23$ & B71989-F-7 & $\begin{array}{l}{ }^{137} \mathrm{Cs} \text { on Cladding } \\
\text { Interior }\end{array}$ & $1.510 \mathrm{e}+10$ & $5.60 \mathrm{e}+08$ & $\mathrm{~d} / \mathrm{m} / \mathrm{cm} 2$ & $08 / 12 / 88$ \\
\hline 106 & NBD131 & J & $88-23$ & B71989-F-7 & $\begin{array}{l}{ }^{135} \mathrm{Cs} \text { on Cladding } \\
\text { Interior }\end{array}$ & $6.670 e+04$ & $9.30 \mathrm{e}+03$ & $\mathrm{~d} / \mathrm{m} / \mathrm{cm} 2$ & $08 / 12 / 88$ \\
\hline 106 & NBD131 & J & $88-23$ & B71989-G-7 & $\begin{array}{l}129 \text { I on Cladding } \\
\text { Interior }\end{array}$ & $2.060 \mathrm{e}+04$ & $6.20 \mathrm{e}+02$ & $\mathrm{~d} / \mathbf{m} / \mathrm{cm} 2$ & $08 / 15 / 88$ \\
\hline 106 & NBD131 & $\mathrm{K}$ & $88-24$ & B71989-D-7 & ${ }^{14} \mathrm{C}$ in Fuel & $1.620 \mathrm{e}-06$ & $1.60 \mathrm{e}-07$ & $\mathrm{Ci} / \mathrm{g}$ fuel & \\
\hline 106 & NBD131 & K & $88-24$ & B71989-D-7 & ${ }^{14} \mathrm{C}$ in Fuel & $1.650 \mathrm{e}-06$ & $1.70 \mathrm{e}-07$ & $\mathrm{Ci} / \mathrm{g}$ fuel & \\
\hline
\end{tabular}


Table B.1. (contd)

\begin{tabular}{|c|c|c|c|c|c|c|c|c|c|}
\hline ATM & Rod & Section & $\begin{array}{l}\text { Sample } \\
\text { Number }\end{array}$ & $\begin{array}{l}\text { Analytical } \\
\text { Request }\end{array}$ & Type of Analysis & Measured Value & Uncertainties & $\begin{array}{l}\text { Measured } \\
\text { Value Units }\end{array}$ & $\begin{array}{c}\text { Date } \\
\text { Measured }\end{array}$ \\
\hline 106 & NBD131 & $\mathbf{K}$ & $88-24$ & B71989-E-7 & ${ }^{14} \mathrm{C}$ in Cladding & $3.270 \mathrm{e}-06$ & $3.30 \mathrm{e}-07$ & $\mathrm{Ci} / \mathrm{g} \mathrm{Zr}$ & \\
\hline 106 & NBD131 & $\mathbf{K}$ & $88-24$ & B71989-E-7 & ${ }^{14} \mathrm{C}$ in Cladding & $3.450 \mathrm{e}-06$ & $3.50 \mathrm{e}-07$ & $\mathrm{Ci} / \mathrm{g} \mathrm{Zr}$ & \\
\hline 106 & NBD131 & $\mathrm{N}$ & $88-26$ & B71989-F-7 & $\begin{array}{l}{ }^{137} \mathrm{Cs} \text { on Cladding } \\
\text { Interior }\end{array}$ & $4.860 e+09$ & $1.80 \mathrm{e}+08$ & $\mathrm{~d} / \mathrm{m} / \mathrm{cm} 2$ & $08 / 12 / 88$ \\
\hline 106 & NBD131 & $\mathrm{N}$ & $88-26$ & B71989-F-7 & $\begin{array}{l}{ }^{135} \mathrm{Cs} \text { on Cladding } \\
\text { Interior }\end{array}$ & $2.200 e+04$ & $3.10 \mathrm{e}+03$ & $\mathrm{~d} / \mathrm{m} / \mathrm{cm} 2$ & $08 / 12 / 88$ \\
\hline 106 & NBD131 & $\mathbf{N}$ & $88-26$ & B71989-G-7 & $\begin{array}{l}{ }^{129} \text { I on Cladding } \\
\text { Interior }\end{array}$ & $5.980 e+03$ & $1.80 e+02$ & $\mathrm{~d} / \mathrm{m} / \mathrm{cm} 2$ & $08 / 15 / 88$ \\
\hline 106 & NBD131 & Q & $88-28$ & B71989-B-7 & $\begin{array}{l}\text { Measured Fuel } \\
\text { Burnup }\end{array}$ & $4.965 e+01$ & & $\mathrm{MWd} / \mathrm{kgM}$ & \\
\hline 106 & NBD131 & $Q$ & $88-28$ & B71989-B-7 & ${ }^{234} \mathrm{U}$ & $1.000 \mathrm{e}-02$ & $2.00 \mathrm{e}-03$ & ${ }^{234} \mathrm{U} w \mathrm{t} \%$ & \\
\hline 106 & NBD131 & $\mathbf{Q}$ & $88-28$ & B71989-B-7 & ${ }^{235} \mathrm{U}$ & $1.180 \mathrm{e}-01$ & $5.00 \mathrm{e}-03$ & ${ }^{235} \mathrm{U} w \mathrm{t} \%$ & \\
\hline 106 & NBD131 & Q & $88-28$ & B71989-B-7 & ${ }^{236} U$ & $3.660 \mathrm{e}-01$ & $5.00 \mathrm{e}-03$ & ${ }^{236} \mathrm{U} w \mathrm{t} \%$ & \\
\hline 106 & NBD131 & $\mathbf{Q}$ & $88-28$ & B71989-B-7 & $238 U$ & $9.951 e+01$ & $1.00 \mathrm{e}-02$ & ${ }^{238} \mathrm{U}$ wt\% & \\
\hline 106 & NBD131 & $\mathbf{Q}$ & $88-28$ & B71989-B-7 & ${ }^{238} \mathrm{Pu}$ & $3.381 \mathrm{e}+00$ & $3.10 \mathrm{e}-02$ & ${ }^{238} \mathrm{Pu} w \mathrm{wt} \%$ & \\
\hline 106 & NBD131 & $\mathbf{Q}$ & $88-28$ & B71989-B-7 & ${ }^{239} \mathrm{Pu}$ & $4.190 \mathrm{e}+01$ & $2.06 \mathrm{e}-01$ & ${ }^{239} \mathrm{Pu} w \mathrm{w} \%$ & \\
\hline 106 & NBD131 & Q & $88-28$ & B71989-B-7 & ${ }^{240} \mathrm{Pu}$ & $3.017 e+01$ & $2.06 \mathrm{e}-01$ & ${ }^{240} \mathrm{Pu} w t \%$ & \\
\hline 106 & NBD131 & $\mathbf{Q}$ & 88-28 & B71989-B-7 & ${ }^{241} \mathrm{Pu}$ & $9.588 \mathrm{e}+00$ & $6.90 \mathrm{e}-02$ & ${ }^{241} \mathrm{Pu} w \mathrm{t} \%$ & \\
\hline 106 & NBD131 & $Q$ & $88-28$ & B71989-B-7 & ${ }^{242} \mathrm{Pu}$ & $1.497 e+01$ & $1.11 \mathrm{e}-01$ & ${ }^{242} \mathrm{Pu} w t \%$ & \\
\hline 106 & NBD131 & $Q$ & $88-28$ & B71989-B-7 & ${ }^{79} \mathrm{Se}$ & $1.720 \mathrm{e}+05$ & $4.10 \mathrm{e}+03$ & $\mathrm{~d} / \mathrm{m} / \mathrm{g}$ fuel & 07/07/88 \\
\hline 106 & NBD131 & $\mathbf{Q}$ & $88-28$ & B71989-B-7 & ${ }^{90} \mathrm{Sr}$ & $1.460 \mathrm{e}+11$ & $4.70 \mathrm{e}+09$ & $\mathrm{~d} / \mathrm{m} / \mathrm{g}$ fuel & $07 / 06 / 88$ \\
\hline 106 & NBD131 & $Q$ & $88-28$ & B71989-B-7 & ${ }^{99} \mathrm{Tc}$ & $3.460 e+07$ & $1.00 e+06$ & $\mathrm{~d} / \mathrm{m} / \mathrm{g}$ fuel & $06 / 27 / 88$ \\
\hline 106 & NBD131 & $\mathbf{Q}$ & $88-28$ & B71989-B-7 & ${ }^{126} \mathrm{Sn}$ & $5.990 e+05$ & $6.00 \mathrm{e}+04$ & $\mathrm{~d} / \mathrm{m} / \mathrm{g}$ fuel & $06 / 24 / 88$ \\
\hline
\end{tabular}


Table B.1. (contd)

\begin{tabular}{|c|c|c|c|c|c|c|c|c|c|}
\hline ATM & Rod & Section & $\begin{array}{l}\text { Sample } \\
\text { Number }\end{array}$ & $\begin{array}{c}\text { Analytical } \\
\text { Request }\end{array}$ & Type of Analysis & Measured Value & Uncertainties & $\begin{array}{c}\text { Measured } \\
\text { Value Units }\end{array}$ & $\begin{array}{c}\text { Date } \\
\text { Measured }\end{array}$ \\
\hline 106 & NBD131 & $\mathbf{Q}$ & $88-28$ & B71989-B-7 & ${ }^{135} \mathrm{Cs}$ & $9.600 e+05$ & $1.20 \mathrm{e}+05$ & $\mathrm{~d} / \mathrm{m} / \mathrm{g}$ fuel & $07 / 05 / 88$ \\
\hline 106 & NBD131 & Q & $88-28$ & B71989-B-7 & ${ }^{137} \mathrm{Cs}$ & $2.330 \mathrm{e}+11$ & $4.70 \mathrm{e}+09$ & $\mathrm{~d} / \mathrm{m} / \mathrm{g}$ fuel & $07 / 05 / 88$ \\
\hline 106 & NBD131 & Q & $88-28$ & B71989-B-7 & ${ }^{237} \mathrm{~Np}$ & $5.560 e+05$ & $1.70 e+04$ & $\mathrm{~d} / \mathrm{m} / \mathrm{g}$ fuel & $09 / 20 / 88$ \\
\hline 106 & NBD131 & $\mathbf{Q}$ & $88-28$ & B71989-B-7 & ${ }^{241} \mathrm{Am}$ & $3.400 \mathrm{e}+09$ & $1.60 \mathrm{e}+08$ & $\mathrm{~d} / \mathrm{m} / \mathrm{g}$ fuel & $07 / 14 / 88$ \\
\hline 106 & NBD131 & $\mathbf{Q}$ & $88-28$ & B71989-B-7 & $243 \&{ }^{244} \mathrm{Cm}$ & $2.640 \mathrm{e}+10$ & $6.10 e+08$ & $\mathrm{~d} / \mathrm{m} / \mathrm{g}$ fuel & $07 / 14 / 88$ \\
\hline 106 & NBD131 & $Q$ & $88-28$ & B71989-B-7 & ${ }^{243} \mathrm{Am}$ in Fuel & $3.490 e+08$ & $6.60 e+07$ & $\mathrm{~d} / \mathrm{m} / \mathrm{g}$ fuel & $07 / 14 / 88$ \\
\hline 106 & NBD131 & $Q$ & $88-28$ & B71989-B-7 & ${ }^{242} \mathrm{Cm}$ in Fuel & $2.240 e+07$ & $1.00 \mathrm{e}+06$ & $\mathrm{~d} / \mathrm{m} / \mathrm{g}$ fuel & $07 / 14 / 88$ \\
\hline 106 & NBD131 & Q & $88-28$ & B71989-B-7 & $\begin{array}{l}\text { Measured Fuel } \\
\text { Burnup }\end{array}$ & $4.965 e+04$ & & MWd/MTM & \\
\hline 106 & NBD131 & $\mathbf{Q}$ & $88-28$ & B71989-B-7 & ${ }^{143 / 148} \mathrm{Nd}$ & $1.341 \mathrm{e}+00$ & & ${ }^{143 / 148} \mathrm{Nd}$ & \\
\hline 106 & NBD131 & $\mathbf{Q}$ & $88-28$ & B71989-B-7 & ${ }^{144 / 148} \mathrm{Nd}$ & $4.216 \mathrm{e}+00$ & & $144 / 148 \mathrm{Nd}$ & \\
\hline 106 & NBD131 & Q & $88-28$ & B71989-B-7 & ${ }^{145 / 148} \mathrm{Nd}$ & $1.628 \mathrm{e}+00$ & & ${ }^{145 / 148} \mathrm{Nd}$ & \\
\hline 106 & NBD131 & $\mathbf{Q}$ & $88-28$ & B71989-B-7 & $146 / 148 \mathrm{Nd}$ & $1.995 \mathrm{e}+00$ & & ${ }^{146 / 148} \mathrm{Nd}$ & \\
\hline 106 & NBD131 & Q & $88-28$ & B71989-B-7 & ${ }^{148} \mathrm{Nd}$ in Fuel & $1.973 e+18$ & & Atoms/g Fuel & \\
\hline 106 & NBD131 & $\mathbf{Q}$ & $88-28$ & B71989-B-7 & ${ }^{150 / 148} \mathrm{Nd}$ & $4.954 \mathrm{e}-01$ & & ${ }^{150 / 148} . \mathrm{Nd}$ & \\
\hline 106 & NBD131 & $\mathbf{R}$ & 88-29 & B71989-C-7 & ${ }^{129} \mathrm{I}$ in Fuel & $1.110 \mathrm{e}+05$ & $2.40 e+03$ & $\mathrm{~d} / \mathrm{m} / \mathrm{g}$ fuel & $08 / 03 / 88$ \\
\hline 106 & NBD131 & $\mathbf{R}$ & $88-29$ & B71989-F-7 & $\begin{array}{l}{ }^{137} \mathrm{Cs} \text { on Cladding } \\
\text { Interior }\end{array}$ & $5.090 \mathrm{e}+09$ & $1.90 e+08$ & $\mathrm{~d} / \mathrm{m} / \mathrm{cm} 2$ & $08 / 12 / 88$ \\
\hline 106 & NBD131 & $\mathbf{R}$ & $88-29$ & B71989-F-7 & $\begin{array}{l}{ }^{135} \mathrm{Cs} \text { on Cladding } \\
\text { Interior }\end{array}$ & $2.300 \mathrm{e}+04$ & $3.20 \mathrm{e}+03$ & $\mathrm{~d} / \mathrm{m} / \mathrm{cm} 2$ & $08 / 12 / 88$ \\
\hline 106 & NBD131 & $\mathbf{R}$ & $88-29$ & B71989-G-7 & $\begin{array}{l}129 \text { I on Cladding } \\
\text { Interior }\end{array}$ & $4.190 \mathrm{e}+03$ & $1.30 \mathrm{e}+02$ & $\mathrm{~d} / \mathrm{m} / \mathrm{cm} 2$ & $08 / 15 / 88$ \\
\hline 106 & NBD131 & s & $88-30$ & B71989-D-7 & ${ }^{14} \mathrm{C}$ in Fuel & $1.910 \mathrm{e}-06$ & $1.90 \mathrm{e}-07$ & $\mathrm{Ci} / \mathrm{g}$ fuel & \\
\hline
\end{tabular}


Table B.1. (contd)

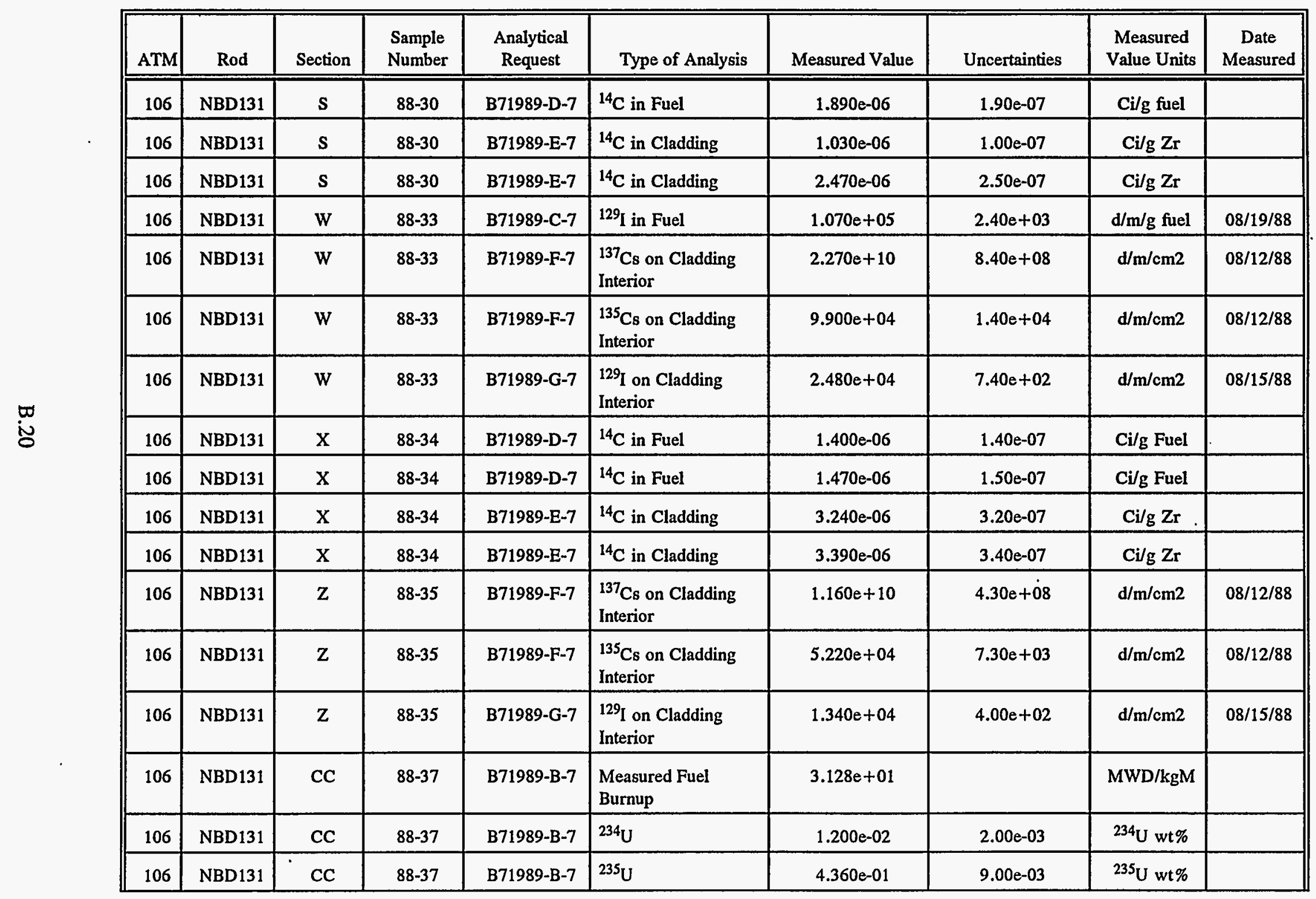


Table B.1. (contd)

\begin{tabular}{|c|c|c|c|c|c|c|c|c|c|}
\hline ATM & Rod & Section & $\begin{array}{l}\text { Sample } \\
\text { Number }\end{array}$ & $\begin{array}{c}\text { Analytical } \\
\text { Request }\end{array}$ & Type of Analysis & Measured Value & Uncertainties & $\begin{array}{c}\text { Measured } \\
\text { Value Units }\end{array}$ & $\begin{array}{c}\text { Date } \\
\text { Measured }\end{array}$ \\
\hline 106 & NBD131 & $\mathrm{CC}$ & $88-37$ & B71989-B-7 & ${ }^{236} \mathrm{U}$ & $3.390 \mathrm{e}-01$ & $5.00 \mathrm{e}-03$ & ${ }^{236} \mathrm{U}$ wt\% & \\
\hline 106 & NBD131 & $\mathrm{CC}$ & $88-37$ & B71989-B-7 & ${ }^{238} \mathrm{U}$ & $9.921 \mathrm{e}+01$ & $1.00 \mathrm{e}-02$ & ${ }^{238} \mathrm{U} w \mathrm{wt} \%$ & \\
\hline 106 & NBD131 & $\mathrm{CC}$ & $88-37$ & B71989-B-7 & ${ }^{238} \mathrm{Pu}$ & $2.176 e+00$ & $3.76 \mathrm{e}-01$ & ${ }^{238} \mathrm{Pu}$ wt $\%$ & \\
\hline 106 & NBD131 & $\mathrm{CC}$ & $88-37$ & B71989-B-7 & ${ }^{239} \mathrm{Pu}$ & $5.226 \mathrm{e}+01$ & $3.28 \mathrm{e}-01$ & ${ }^{239} \mathrm{Pu}$ wt \% & \\
\hline 106 & NBD131 & $\mathrm{CC}$ & $88-37$ & B71989-B-7 & ${ }^{240} \mathrm{Pu}$ & $2.846 e+01$ & $1.79 \mathrm{e}-01$ & ${ }^{240} \mathrm{Pu} w t \%$ & \\
\hline 106 & NBD131 & $\mathrm{CC}$ & $88-37$ & B71989-B-7 & ${ }^{241} \mathrm{Pu}$ & $9.502 e+00$ & $6.60 \mathrm{e}-02$ & ${ }^{241} \mathrm{Pu} w t \%$ & \\
\hline 106 & NBD131 & $\mathrm{CC}$ & $88-37$ & B71989-B-7 & ${ }^{242} \mathrm{Pu}$ & $7.604 e+00$ & $8.40 \mathrm{e}-02$ & ${ }^{242} \mathrm{Pu} w t \%$ & \\
\hline 106 & NBD131 & $\mathrm{CC}$ & $88-37$ & B71989-B-7 & $\begin{array}{l}{ }^{243} \mathrm{Cm} \&{ }^{244} \mathrm{Cm} \text { in } \\
\text { Fuel }\end{array}$ & $3.790 e+09$ & $6.10 e+07$ & $\mathrm{~d} / \mathrm{m} / \mathrm{g}$ fuel & $07 / 14 / 88$ \\
\hline 106 & NBD131 & $\mathrm{CC}$ & $88-37$ & B71989-B-7 & ${ }^{79} \mathrm{Se}$ & $1.220 \mathrm{e}+05$ & $2.90 \mathrm{e}+03$ & $\mathrm{~d} / \mathrm{m} / \mathrm{g}$ fuel & $07 / 07 / 88$ \\
\hline 106 & NBD131 & $\mathrm{CC}$ & 88-37 & B71989-B-7 & ${ }^{90} \mathrm{Sr}$ & $1.050 \mathrm{e}+11$ & $3.40 \mathrm{e}+09$ & $\mathrm{~d} / \mathrm{m} / \mathrm{g}$ fuel & $07 / 06 / 88$ \\
\hline 106 & NBD131 & $\mathrm{CC}$ & 88-37 & B71989-B-7 & ${ }^{99} \mathrm{Tc}$ & $2.370 e+07$ & $8.10 e+05$ & $\mathrm{~d} / \mathrm{m} / \mathrm{g}$ fuel & $06 / 27 / 88$ \\
\hline 106 & NBD131 & $\mathrm{CC}$ & $88-37$ & B71989-B-7 & ${ }^{126} \mathrm{Sn}$ & $3.700 \mathrm{e}+05$ & $3.70 \mathrm{e}+04$ & $\mathrm{~d} / \mathrm{m} / \mathrm{g}$ fuel & $06 / 24 / 88$ \\
\hline 106 & NBD131 & $\mathrm{CC}$ & 88-37 & B71989-B-7 & ${ }^{135} \mathrm{Cs}$ & $8.800 e+05$ & $1.10 \mathrm{e}+05$ & $\mathrm{~d} / \mathrm{m} / \mathrm{g}$ fuel & $07 / 05 / 88$ \\
\hline 106 & NBD131 & $\mathrm{CC}$ & $88-37$ & B71989-B-7 & ${ }^{137} \mathrm{Cs}$ & $1.630 \mathrm{e}+11$ & $3.30 \mathrm{e}+09$ & $\mathrm{~d} / \mathrm{m} / \mathrm{g}$ fuel & $07 / 05 / 88$ \\
\hline 106 & NBD131 & $\mathrm{CC}$ & $88-37$ & B71989-B-7 & ${ }^{237} \mathrm{~Np}$ & $4.180 \mathrm{e}+05$ & $1.30 \mathrm{e}+04$ & $\mathrm{~d} / \mathrm{m} / \mathrm{g}$ fuel & $09 / 20 / 88$ \\
\hline 106 & NBD131 & $\mathrm{CC}$ & $88-37$ & B71989-B-7 & ${ }^{241} \mathrm{Am}$ & $2.600 \mathrm{e}+09$ & $4.20 \mathrm{e}+07$ & $\mathrm{~d} / \mathrm{m} / \mathrm{g}$ fuel & $07 / 14 / 88$ \\
\hline 106 & NBD131 & $\mathrm{CC}$ & $88-37$ & B71989-B-7 & ${ }^{243} \mathrm{Am}$ in Fuel & $7.670 e+07$ & $1.20 \mathrm{e}+07$ & $\mathrm{~d} / \mathrm{m} / \mathrm{g}$ fuel & $07 / 14 / 88$ \\
\hline 106 & NBD131 & $\mathrm{CC}$ & $88-37$ & B71989-B-7 & ${ }^{242} \mathrm{Cm}$ in Fuel & $1.870 e+07$ & $8.00 e+05$ & $\mathrm{~d} / \mathrm{m} / \mathrm{g}$ fuel & $07 / 14 / 88$ \\
\hline 106 & NBD131 & $\mathrm{CC}$ & $88-37$ & B71989-B-7 & $\begin{array}{l}\text { Measured Fuel } \\
\text { Burnup }\end{array}$ & $3.128 \mathrm{e}+04$ & & $\mathrm{MWd} / \mathrm{MTM}$ & \\
\hline 106 & NBD131 & $\mathrm{CC}$ & $88-37$ & B71989-B-7 & $143 / 148 \mathrm{Nd}$ & $1.941 \mathrm{e}+00$ & & ${ }^{143 / 148} \mathrm{Nd}$ & \\
\hline
\end{tabular}


Table B.1. (contd)

\begin{tabular}{|c|c|c|c|c|c|c|c|c|c|}
\hline ATM & Rod & Section & $\begin{array}{l}\text { Sample } \\
\text { Number }\end{array}$ & $\begin{array}{c}\text { Analytical } \\
\text { Request }\end{array}$ & Type of Analysis & Measured Value & Uncertainties & $\begin{array}{c}\text { Measured } \\
\text { Value Units }\end{array}$ & $\begin{array}{c}\text { Date } \\
\text { Measured }\end{array}$ \\
\hline 106 & NBD131 & CC & $88-37$ & B71989-B-7 & ${ }^{144 / 148} \mathrm{Nd}$ & $3.828 \mathrm{e}+00$ & & $144 / 148 \mathrm{Nd}$ & \\
\hline 106 & NBD131 & $\mathrm{CC}$ & $88-37$ & B71989-B-7 & ${ }^{145 / 148} \mathrm{Nd}$ & $1.836 e+00$ & & ${ }^{145 / 148} \mathrm{Nd}$ & \\
\hline 106 & NBD131 & CC & $88-37$ & B71989-B-7 & ${ }^{146 / 148} \mathrm{Nd}$ & $1.870 \mathrm{e}+00$ & & ${ }^{146 / 148} \mathrm{Nd}$ & \\
\hline 106 & NBD131 & $\mathrm{CC}$ & 88-37 & B71989-B-7 & ${ }^{148} \mathrm{Nd}$ in Fuel & $1.238 e+18$ & & Atoms/g Fuel & \\
\hline 106 & NBD131 & $\mathrm{cc}$ & 88-37 & B71989-B-7 & ${ }^{150 / 148} \mathrm{Nd}$ & $4.787 \mathrm{e}-01$ & & ${ }^{150 / 148} \mathrm{Nd}$ & \\
\hline 106 & NBD131 & DD & $88-38$ & B71989-C-7 & ${ }^{129} \mathrm{I}$ in Fuel & $5.930 e+04$ & $1.20 e+03$ & $\mathrm{~d} / \mathrm{m} / \mathrm{g}$ fuel & $08 / 19 / 88$ \\
\hline 106 & NBD131 & DD & $88-38$ & B71989-F-7 & $\begin{array}{l}{ }^{137} \mathrm{Cs} \text { on Cladding } \\
\text { Interior }\end{array}$ & $8.220 e+09$ & $3.00 \mathrm{e}+08$ & $\mathrm{~d} / \mathrm{m} / \mathrm{cm} 2$ & $08 / 12 / 88$ \\
\hline 106 & NBD131 & DD & $88-38$ & B71989-F-7 & $\begin{array}{l}{ }^{135} \mathrm{Cs} \text { on Cladding } \\
\text { Interior }\end{array}$ & $5.010 \mathrm{e}+04$ & $7.00 e+03$ & $\mathrm{~d} / \mathrm{m} / \mathrm{cm} 2$ & $08 / 12 / 88$ \\
\hline 106 & NBD131 & DD & $88-38$ & B71989-G-7 & $\begin{array}{l}129 \text { I on Cladding } \\
\text { Interior }\end{array}$ & $1.080 \mathrm{e}+04$ & $3.20 e+02$ & $\mathrm{~d} / \mathrm{m} / \mathrm{cm} 2$ & $08 / 15 / 88$ \\
\hline 106 & NBD131 & $\mathrm{EE}$ & $88-39$ & B71989-D-7 & ${ }^{14} \mathrm{C}$ in Fuel & $4.870 \mathrm{e}-07$ & $4.90 \mathrm{e}-08$ & $\mathrm{Ci} / \mathrm{g}$ Fuel & \\
\hline 106 & NBD131 & $\mathrm{EE}$ & $88-39$ & B71989-D-7 & ${ }^{14} \mathrm{C}$ in Fuel & $4.560 \mathrm{e}-07$ & $4.60 \mathrm{e}-08$ & $\mathrm{Ci} / \mathrm{g}$ Fuel & \\
\hline 106 & NBD131 & $\mathrm{EE}$ & $88-39$ & B71989-E-7 & ${ }^{14} \mathrm{C}$ in Cladding & $1.050 \mathrm{e}-06$ & $1.10 \mathrm{e}-07$ & $\mathrm{Ci} / \mathrm{g} \mathrm{Zr}$ & \\
\hline 106 & NBD131 & $\mathrm{EE}$ & $88-39$ & B71989-E-7 & ${ }^{14} \mathrm{C}$ in Cladding & $1.050 \mathrm{e}-06$ & $1.10 \mathrm{e}-07$ & $\mathrm{Ci} / \mathrm{g} \mathrm{Zr}$ & \\
\hline 108 & ADN0206 & D & $89-37$ & B71989-B-10 & $\begin{array}{l}\text { Measured Fuel } \\
\text { Burnup }\end{array}$ & $1.221 \mathrm{e}+01$ & & $\mathrm{MWd} / \mathrm{KgM}$ & \\
\hline 108 & ADN0206 & D & 89-37 & B71989-B-10 & ${ }^{234} \mathrm{U}$ in Fuel & $2.000 \mathrm{e}-02$ & $1.00 \mathrm{e}-03$ & ${ }^{234} \mathrm{U} w t \%$ & \\
\hline 108 & ADN0206 & D & $89-37$ & B71989-B-10 & ${ }^{235} \mathrm{U}$ & $1.816 \mathrm{e}+00$ & $2.00 \mathrm{e}-02$ & ${ }^{235} \mathrm{U} w t \%$ & . \\
\hline 108 & ADN0206 & D & $89-37$ & B71989-B-10 & ${ }^{236} \mathrm{U}$ & $2.180 \mathrm{e}-01$ & $2.00 \mathrm{e}-03$ & ${ }^{236} \mathrm{U}$ wt\% & \\
\hline 108 & ADN0206 & D & $89-37$ & B71989-B-10 & ${ }^{238} U$ & $9.795 e+01$ & $2.00 \mathrm{e}-02$ & ${ }^{238} \mathrm{U} w t \%$ & \\
\hline 108 & ADN0206 & D & $89-37$ & B71989-B-10 & ${ }^{238} \mathrm{Pu}$ & $4.600 \mathrm{e}-01$ & $5.00 \mathrm{e}-03$ & ${ }^{238} \mathrm{Pu} w t \%$ & \\
\hline
\end{tabular}


Table B.1. (contd)

\begin{tabular}{|c|c|c|c|c|c|c|c|c|c|}
\hline ATM & Rod & Section & $\begin{array}{l}\text { Sample } \\
\text { Number }\end{array}$ & $\begin{array}{c}\text { Analytical } \\
\text { Request }\end{array}$ & Type of Analysis & Measured Value & Uncertainties & $\begin{array}{c}\text { Measured } \\
\text { Value Units }\end{array}$ & $\begin{array}{c}\text { Date } \\
\text { Measured }\end{array}$ \\
\hline 108 & ADN0206 & D & $89-37$ & B71989-B-10 & ${ }^{239} \mathrm{Pu}$ & $7.507 e+01$ & $1.00 \mathrm{e}-01$ & ${ }^{239} \mathrm{Pu}$ wit\% & \\
\hline 108 & ADN0206 & D & $89-37$ & B71989-B-10 & ${ }^{240} \mathrm{Pu}$ & $1.963 e+01$ & $1.00 \mathrm{e}-01$ & $240 \mathrm{Pu} w t \%$ & \\
\hline 108 & ADN0206 & D & $89-37$ & B71989-B-10 & ${ }^{241} \mathrm{Pu}$ & $3.963 e+00$ & $3.00 \mathrm{e}-02$ & ${ }^{241} \mathrm{Pu}$ wt $\%$ & \\
\hline 108 & ADN0206 & D & $89-37$ & B71989-B-10 & ${ }^{242} \mathrm{Pu}$ & $8.800 \mathrm{e}-01$ & $5.00 \mathrm{e}-03$ & ${ }^{242} \mathrm{Pu} w t \%$ & \\
\hline 108 & ADN0206 & D & $89-37$ & B71989-B-10 & ${ }^{143 / 148} \mathrm{Nd}$ & $2.890 e+00$ & & ${ }^{143 / 148} \mathrm{Nd}$ & \\
\hline 108 & ADN0206 & D & $89-37$ & B71989-B-10 & ${ }^{144 / 148} \mathrm{Nd}$ & $3.383 e+00$ & & ${ }^{144 / 148} \mathrm{Nd}$ & \\
\hline 108 & ADN0206 & D & $89-37$ & B71989-B-10 & ${ }^{145 / 148} \mathrm{Nd}$ & $2.128 \mathrm{e}+00$ & & ${ }^{145 / 148} \mathrm{Nd}$ & \\
\hline 108 & ADN0206 & D & $89-37$ & B71989-B-10 & ${ }^{146 / 148} \mathrm{Nd}$ & $1.791 \mathrm{e}+00$ & & ${ }^{146 / 148} \mathrm{Nd}$ & \\
\hline 108 & ADN0206 & D & 89-37 & B71989-B-10 & ${ }^{148} \mathrm{Nd}$ in Fuel & $3.890 e+17$ & & \multicolumn{2}{|c|}{ Atoms/g Fuel } \\
\hline 108 & ADN0206 & $\mathrm{D}$ & $89-37$ & B71989-B-10 & ${ }^{150 / 148} \mathrm{Nd}$ & $4.427 \mathrm{e}-01$ & & ${ }^{150 / 148} \mathrm{Nd}$ & \\
\hline 108 & ADN0206 & $\mathbf{M}$ & $89-45$ & B71989-B-10 & $\begin{array}{l}\text { Measured Fuel } \\
\text { Burnup }\end{array}$ & $1.958 \mathrm{e}+01$ & & $\mathrm{MWd} / \mathrm{kgM}$ & \\
\hline 108 & ADN0206 & M & $89-45$ & B71989-B-10 & ${ }^{234} U$ & $1.700 \mathrm{e}-02$ & $1.00 \mathrm{e}-03$ & ${ }^{234} \mathrm{U} w \mathrm{t} \%$ & \\
\hline 108 & ADN0206 & M & $89-45$ & B71989-B-10 & ${ }^{235} \mathrm{U}$ & $1.413 e+00$ & $1.00 \mathrm{e}-02$ & ${ }^{235} \mathrm{U} w \mathrm{t} \%$ & \\
\hline 108 & ADN0206 & $\mathrm{M}$ & $89-45$ & B71989-B-10 & ${ }^{236} \mathrm{U}$ & $3.080 \mathrm{e}-01$ & $3.00 \mathrm{e}-03$ & ${ }^{236} \mathrm{U} \mathrm{wt} \%$ & \\
\hline 108 & ADN0206 & $\mathrm{M}$ & $89-45$ & B71989-B-10 & ${ }^{238} \mathrm{U}$ & $9.826 e+01$ & $1.00 \mathrm{e}-02$ & ${ }^{238} \mathrm{U} w \mathrm{t} \%$ & \\
\hline 108 & ADN0206 & $\mathbf{M}$ & $89-45$ & B71989-B-10 & ${ }^{238} \mathrm{Pu}$ & $1.114 \mathrm{e}+00$ & $2.00 \mathrm{e}-02$ & ${ }^{238} \mathrm{Pu}$ wt $\%$ & \\
\hline 108 & ADN0206 & $\mathrm{M}$ & $89-45$ & B71989-B-10 & ${ }^{239} \mathrm{Pu}$ & $6.708 \mathrm{e}+01$ & $1.00 \mathrm{e}-01$ & ${ }^{239} \mathrm{Pu}$ wt $\%$ & \\
\hline 108 & ADN0206 & $\mathbf{M}$ & $89-45$ & B71989-B-10 & ${ }^{240} \mathrm{Pu}$ & $2.334 \mathrm{e}+01$ & $1.00 \mathrm{e}-01$ & ${ }^{240} \mathrm{Pu} w t \%$ & \\
\hline 108 & ADN0206 & $\mathbf{M}$ & $89-45$ & B71989-B-10 & ${ }^{241} \mathrm{Pu}$ & $6.287 e+00$ & $4.00 \mathrm{e}-02$ & ${ }^{241} \mathrm{Pu} w \mathrm{t} \%$ & \\
\hline 108 & ADN0206 & $M$ & $89-45$ & B71989-B-10 & ${ }^{242} \mathrm{Pu}$ & $2.189 e+00$ & $2.00 \mathrm{e}-02$ & ${ }^{242} \mathrm{Pu}$ wt $\%$ & \\
\hline
\end{tabular}


Table B.1. (contd)

\begin{tabular}{|c|c|c|c|c|c|c|c|c|c|}
\hline ATM & Rod & Section & $\begin{array}{l}\text { Sample } \\
\text { Number }\end{array}$ & $\begin{array}{l}\text { Analytical } \\
\text { Request }\end{array}$ & Type of Analysis & Measured Value & Uncertainties & $\begin{array}{c}\text { Measured } \\
\text { Value Units }\end{array}$ & $\begin{array}{c}\text { Date } \\
\text { Measured }\end{array}$ \\
\hline 108 & ADN0206 & $\mathbf{M}$ & $89-45$ & B71989-B-10 & ${ }^{143 / 148} \mathrm{Nd}$ & $2.665 \mathrm{e}+00$ & & ${ }^{143 / 148} \mathrm{Nd}$ & \\
\hline 108 & ADN0206 & $\mathbf{M}$ & $89-45$ & B71989-B-10 & ${ }^{144 / 148} \mathrm{Nd}$ & $3.441 e+00$ & & ${ }^{144 / 148} \mathrm{Nd}$ & \\
\hline 108 & ADN0206 & $\mathbf{M}$ & $89-45$ & B71989-B-10 & ${ }^{145 / 148} \cdot{ }^{\mathrm{Nd}}$ & $2.018 \mathrm{e}+00$ & & ${ }^{145 / 148} \mathrm{Nd}$ & \\
\hline 108 & ADN0206 & $\mathbf{M}$ & $89-45$ & B71989-B-10 & ${ }^{146 / 148} \mathrm{Nd}$ & $1.826 e+00$ & & $146 / 148 \mathrm{Nd}$ & \\
\hline 108 & ADN0206 & M & $89-45^{\circ}$ & B71989-B-10 & ${ }^{148} \mathrm{Nd}$ in Fuel & $6.360 e+17$ & & Atoms/g Fuel & \\
\hline 108 & ADN0206 & $\mathbf{M}$ & $89-45$ & B71989-B-10 & ${ }^{150 / 148} \mathrm{Nd}$ & $4.617 \mathrm{e}-01$ & & $150 / 148 \mathrm{Nd}$ & \\
\hline 108 & ADN0206 & DD & $89-60$ & B71989-B-10 & $\begin{array}{l}\text { Measured Fuel } \\
\text { Burnup }\end{array}$ & $2.767 e+01$ & & $\mathrm{MWd} / \mathrm{kgM}$ & \\
\hline 108 & ADN0206 & $\mathrm{DD}$ & $89-60$ & B71989-B-10 & ${ }^{234} \mathrm{U}$ & $1.600 \mathrm{e}-02$ & $1.00 \mathrm{e}-03$ & ${ }^{234} \mathrm{U}$ wt \% & \\
\hline 108 & ADN0206 & $\mathrm{DD}$ & $89-60$ & B71989-B-10 & ${ }^{235} \mathrm{U}$ & $9.890 \mathrm{e}-01$ & $9.00 \mathrm{e}-03$ & ${ }^{235} \mathrm{U}$ wt\% & \\
\hline 108 & ADN0206 & DD & $89-60$ & B71989-B-10 & ${ }^{236} \mathrm{U}$ & $3.800 \mathrm{e}-01$ & $4.00 \mathrm{e}-03$ & ${ }^{236} \mathrm{U} \mathrm{wt} \%$ & \\
\hline 108 & ADN0206 & $\mathrm{DD}$ & $89-60$ & B71989-B-10 & ${ }^{238} \mathrm{U}$ & $9.862 e+01$ & $1.00 \mathrm{e}-02$ & ${ }^{238} \mathrm{U}$ wt\% & \\
\hline 108 & ADN0206 & DD & $89-60$ & B71989-B-10 & ${ }^{238} \mathrm{Pu}$ & $1.907 \mathrm{e}+00$ & $2.00 \mathrm{e}-02$ & ${ }^{238} \mathrm{Pu}$ wt\% & \\
\hline 108 & ADN0206 & DD & $89-60$ & B71989-B-10 & ${ }^{239} \mathrm{Pu}$ & $5.811 \mathrm{e}+01$ & $2.00 \mathrm{e}-01$ & ${ }^{239} \mathrm{Pu}$ wt $\%$ & \\
\hline 108 & ADN0206 & $\mathrm{DD}$ & $89-60$ & B71989-B-10 & ${ }^{240} \mathrm{Pu}$ & $2.784 e+01$ & $2.00 \mathrm{e}-01$ & ${ }^{240} \mathrm{Pu} w \mathrm{t} \%$ & \\
\hline 108 & ADN0206 & $\mathrm{DD}$ & $89-60$ & B71989-B-10 & ${ }^{241} \mathrm{Pu}$ & $7.897 \mathrm{e}+00$ & $5.00 \mathrm{e}-02$ & ${ }^{241} \mathrm{Pu}$ wt $\%$ & \\
\hline 108 & ADN0206 & $\mathrm{DD}$ & $89-60$ & B71989-B-10 & ${ }^{242} \mathrm{Pu}$ & $4.253 e+00$ & $4.00 \mathrm{e}-02$ & ${ }^{242} \mathrm{Pu} w \mathrm{w} \%$ & \\
\hline 108 & ADN0206 & DD & $89-60$ & B71989-B-10 & $143 / 148 \mathrm{Nd}$ & $2.376 e+00$ & & ${ }^{143 / 148} \mathrm{Nd}$ & \\
\hline 108 & ADN0206 & DD & $89-60$ & B71989-B-10 & ${ }^{144 / 148} \mathrm{Nd}$ & $3.601 \mathrm{e}+00$ & & ${ }^{144 / 148} \mathrm{Nd}$ & \\
\hline 108 & ADN0206 & DD & $89-60$ & B71989-B-10 & ${ }^{145 / 148} \mathrm{Nd}$ & $1.931 e+00$ & & ${ }^{145 / 148} \mathrm{Nd}$ & \\
\hline 108 & ADN0206 & DD & $89-60$ & B71989-B-10 & ${ }^{146 / 148} \mathrm{Nd}$ & $1.861 \mathrm{e}+00$ & & $146 / 148 \mathrm{Nd}$ & \\
\hline
\end{tabular}


Table B.1. (contd)

\begin{tabular}{|c|c|c|c|c|c|c|c|c|c|}
\hline ATM & Rod & Section & $\begin{array}{l}\text { Sample } \\
\text { Number }\end{array}$ & $\begin{array}{c}\text { Analytical } \\
\text { Request } \\
\end{array}$ & Type of Analysis & Measured Value & Uncertainties & $\begin{array}{c}\text { Measured } \\
\text { Value Units }\end{array}$ & $\begin{array}{c}\text { Date } \\
\text { Measured }\end{array}$ \\
\hline 108 & ADN0206 & DD & $89-60$ & B71989-B-10 & ${ }^{148} \mathrm{Nd}$ in Fuel & $8.927 e+17$ & & Atoms/g Fuel & \\
\hline 108 & ADN0206 & $\mathrm{DD}$ & $89-60$ & B71989-B-10 & ${ }^{150 / 148} \mathrm{Nd}$ & $4.722 \mathrm{e}-01$ & & ${ }^{150 / 148} \mathrm{Nd}$ & \\
\hline 103 & MLA091 & & $10 \mathrm{~A}$ & B71989-A-13 & He in Gas & $9.940 e+01$ & $1.00 \mathrm{e}+00$ & Mole \% & $03 / 25 / 88$ \\
\hline 103 & MLA091 & & $10 \mathrm{~A}$ & B71989-A-13 & $\mathrm{Xe}$ in Gas & $5.100 \mathrm{e}-01$ & & Mole \% & $03 / 25 / 88$ \\
\hline 103 & MLA091 & & $10 \mathrm{~A}$ & B71989-A-13 & $\mathrm{Xe}-124$ in Gas & $<1 \mathrm{E}-02$ & & Mole \% & $03 / 25 / 88$ \\
\hline 103 & MLA091 & & $10 \mathrm{~A}$ & B71989-A-13 & $\mathrm{Xe}-126$ in Gas & $<1 \mathrm{E}-02$ & & Mole \% & $03 / 25 / 88$ \\
\hline 103 & MLA091 & & $10 \mathrm{~A}$ & B71989-A-13 & $\mathrm{Xe}-128$ in Gas & $<1 \mathrm{E}-02$ & & Mole \% & $03 / 25 / 88$ \\
\hline 103 & MLA091 & & $10 \mathrm{~A}$ & B71989-A-13 & $\mathrm{Xe}-129$ in Gas & $<1 \mathrm{E}-02$ & & Mole \% & $03 / 25 / 88$ \\
\hline 103 & MLA091 & & $10 \mathrm{~A}$ & B71989-A-13 & $\mathrm{Xe}-130$ in Gas & $<1 \mathrm{E}-02$ & & Mole \% & $03 / 25 / 88$ \\
\hline 103 & MLA091 & & $10 \mathrm{~A}$ & B71989-A-13 & $\mathrm{Xe}-131$ in Gas & $4.000 \mathrm{e}-02$ & $4.00 \mathrm{e}-04$ & Mole \% & $03 / 25 / 88$ \\
\hline 103 & MLA091 & & $10 \mathrm{~A}$ & B71989-A-13 & $\mathrm{Xe}-132$ in Gas & $1.100 \mathrm{e}-01$ & $1.00 \mathrm{e}-03$ & Mole \% & $03 / 25 / 88$ \\
\hline 103 & MLA091 & & $10 \mathrm{~A}$ & B71989-A-13 & $\mathrm{Xe}-134$ in Gas & $1.400 \mathrm{e}-01$ & $1.00 \mathrm{e}-03$ & Mole \% & $03 / 25 / 88$ \\
\hline 103 & MLA091 & & $10 \mathrm{~A}$ & B71989-A-13 & $\mathrm{Xe}-136$ in Gas & $2.200 \mathrm{e}-01$ & $2.00 \mathrm{e}-03$ & Mole \% & $03 / 25 / 88$ \\
\hline 103 & MLA091 & & $10 \mathrm{~A}$ & B71989-A-13 & $\mathrm{Kr}$ in Gas & $6.000 \mathrm{e}-02$ & & Mole \% & $03 / 25 / 88$ \\
\hline 103 & MLA091 & & $10 \mathrm{~A}$ & B71989-A-13 & $\mathrm{Kr}-78$ in Gas & $<1 \mathrm{E}-02$ & & Mole \% & $03 / 25 / 88$ \\
\hline 103 & MLA091 & & $10 \mathrm{~A}$ & B71989-A-13 & $\mathrm{Kr}-80$ in Gas & $<1 \mathrm{E}-02$ & & Mole \% & $03 / 25 / 88$ \\
\hline 103 & MLA091 & & $10 \mathrm{~A}$ & B71989-A-13 & $\mathrm{Kr}-82$ in Gas & $<1 \mathrm{E}-02$ & & Mole \% & $03 / 25 / 88$ \\
\hline 103 & MLA091 & & $10 \mathrm{~A}$ & B71989-A-13 & $\mathrm{Kr}-83$ in Gas & $1.000 \mathrm{e}-02$ & $1.00 \mathrm{e}-04$ & Mole \% & $03 / 25 / 88$ \\
\hline 103 & MLA091 & & $10 \mathrm{~A}$ & B71989-A-13 & $\mathrm{Kr}-84$ in Gas & $2.000 \mathrm{e}-02$ & $2.00 \mathrm{e}-04$ & Mole \% & $03 / 25 / 88$ \\
\hline 103 & MLA091 & & $10 \mathrm{~A}$ & B71989-A-13 & $\mathrm{Kr}-86$ in Gas & $3.000 \mathrm{e}-02$ & $3.00 \mathrm{e}-04$ & Mole \% & $03 / 25 / 88$ \\
\hline 103 & MLA091 & & $10 \mathrm{~A}$ & B71989-A-13 & Xe/Kr ratio & $8.500 e+00$ & & & $03 / 25 / 88$ \\
\hline
\end{tabular}


Table B.1. (contd)

\begin{tabular}{|c|c|c|c|c|c|c|c|c|c|}
\hline ATM & Rod & Section & $\begin{array}{c}\text { Sample } \\
\text { Number }\end{array}$ & $\begin{array}{c}\text { Analytical } \\
\text { Request }\end{array}$ & Type of Analysis & Measured Value & Uncertainties & $\begin{array}{l}\text { Measured } \\
\text { Value Units }\end{array}$ & $\begin{array}{c}\text { Date } \\
\text { Measured }\end{array}$ \\
\hline 103 & MLA091 & & $10 \mathrm{~A}$ & B71989-A-13 & Ar in Gas & $<1 \mathrm{E}-02$ & & Mole \% & $03 / 25 / 88$ \\
\hline 103 & MLA091 & & $10 \mathrm{~A}$ & B71989-A-13 & $\mathrm{H} 2$ in Gas & $<1 \mathrm{E}-02$ & & Mole \% & $03 / 25 / 88$ \\
\hline 103 & MLA091 & & $10 \mathrm{~A}$ & B71989-A-13 & $\mathrm{CO} 2$ in Gas & $<1 \mathrm{E}-02$ & & Mole \% & $03 / 25 / 88$ \\
\hline 103 & MLA091 & & $10 \mathrm{~A}$ & B71989-A-13 & CO in Gas & $<3 \mathrm{E}-02$ & & Mole \% & $03 / 25 / 88$ \\
\hline 103 & MLA091 & & $10 \mathrm{~A}$ & B71989-A-13 & N2 in Gas & $3.000 \mathrm{e}-02$ & $3.00 \mathrm{e}-04$ & Mole \% & $03 / 25 / 88$ \\
\hline 103 & MLA091 & & $10 \mathrm{~A}$ & B71989-A-13 & O2 in Gas & $<1 \mathrm{E}-02$ & & Mole $\%$ & $03 / 25 / 88$ \\
\hline 103 & MLA091 & & $10 \mathrm{~A}$ & B71989-A-13 & Organics in Gas & $<1 \mathrm{E}-02$ & & Mole \% & $03 / 25 / 88$ \\
\hline 103 & MLA091 & & $10 \mathrm{~A}$ & B71989-A-14 & ${ }^{14} \mathrm{C}$ in Gas & $5.060 \mathrm{e}-13$ & & $\mathrm{Ci} / \mathrm{cc}$ & $04 / 05 / 88$ \\
\hline 104 & MKP063 & & $10 \mathrm{~A}$ & & Xe-in Gas & $9.850 e+01$ & & Mole $\%$ & $12 / 06 / 88$ \\
\hline 104 & MKP063 & & $10 \mathrm{~A}$ & & $\mathrm{Xe}-124$ in Gas & $1.400 \mathrm{e}+00$ & & Mole \% & $12 / 06 / 88$ \\
\hline 104 & MKP063 & & $10 \mathrm{~A}$ & & $\mathrm{Xe}-126$ in Gas & $<1 \mathrm{E}-02$ & & Mole \% & $12 / 06 / 88$ \\
\hline 104 & MKP063 & & $10 \mathrm{~A}$ & & $\mathrm{Xe}-128$ in Gas & $<1 \mathrm{E}-02$ & & Mole \% & $12 / 06 / 88$ \\
\hline 104 & MKP063 & & $10 \mathrm{~A}$ & & $\mathrm{Xe}-129$ in Gas & $<1 \mathrm{E}-02$ & & Mole \% & $12 / 06 / 88$ \\
\hline 104 & MKP063 & & $10 \mathrm{~A}$ & & $\mathrm{Xe}-130$ in Gas & $<1 \mathrm{E}-02$ & & Mole \% & $12 / 06 / 88$ \\
\hline 104 & MKP063 & & $10 \mathrm{~A}$ & & $\mathrm{Xe}-131$ in Gas & $<1 \mathrm{E}-02$ & & Mole \% & $12 / 06 / 88$ \\
\hline 104 & MKP063 & & $10 \mathrm{~A}$ & & $\mathrm{Xe}-132$ in Gas & $1.000 \mathrm{e}-01$ & $1.00 \mathrm{e}-03$ & Mole \% & $12 / 06 / 88$ \\
\hline 104 & MKP063 & & $10 \mathrm{~A}$ & & $\mathrm{Xe}-134$ in Gas & $3.100 \mathrm{e}-01$ & $3.00 \mathrm{e}-03$ & Mole \% & $12 / 06 / 88$ \\
\hline 104 & MKP063 & & $10 \mathrm{~A}$ & & $\mathrm{Xe}-136$ in Gas & $4.000 \mathrm{e}-01$ & $4.00 \mathrm{e}-03$ & Mole \% & $12 / 06 / 88$ \\
\hline 104 & MKP063 & & $10 \mathrm{~A}$ & & $\mathrm{Kr}$ in Gas & $5.900 \mathrm{e}-01$ & $6.00 \mathrm{e}-03$ & Mole \% & $12 / 06 / 88$ \\
\hline 104 & MKP063 & & $10 \mathrm{~A}$ & & $\mathrm{Kr}-78$ in Gas & $1.300 \mathrm{e}-01$ & & Mole \% & $12 / 06 / 88$ \\
\hline 104 & MKP063 & & $10 \mathrm{~A}$ & & $\mathrm{Kr}-80$ in Gas & $<1 \mathrm{E}-02$ & & Mole \% & $12 / 06 / 88$ \\
\hline
\end{tabular}




\begin{tabular}{|c|c|c|c|c|c|c|c|c|c|c|c|c|c|c|c|c|c|c|c|c|c|}
\hline 焉 & 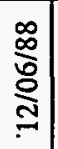 & $\begin{array}{l}\infty \\
\stackrel{0}{0} \\
\stackrel{0}{0} \\
\text { a }\end{array}$ & 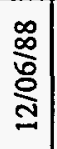 & 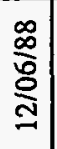 & $\begin{array}{l}\infty \\
\infty \\
\vdots \\
\vdots \\
\stackrel{0}{\leftrightarrows}\end{array}$ & 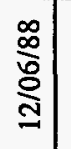 & 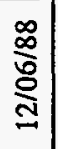 & 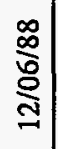 & 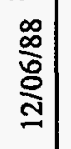 & 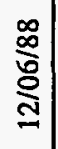 & $\begin{array}{l}\infty \\
\infty \\
\stackrel{0}{0} \\
\stackrel{-}{-}\end{array}$ & 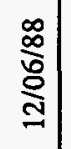 & $\begin{array}{l}\infty \\
\infty \\
\stackrel{0}{0} \\
\stackrel{0}{S}\end{array}$ & 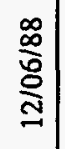 & 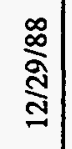 & $\underset{\substack{\infty \\
\stackrel{\infty}{\Xi}}}{\stackrel{\infty}{\delta}}$ & $\stackrel{\infty}{\stackrel{\infty}{\Xi}}$ & $\underset{\substack{\infty \\
\stackrel{\infty}{0}}}{\stackrel{5}{0}}$ & 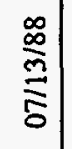 & 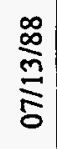 & 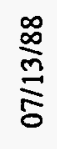 \\
\hline 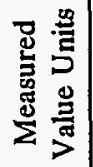 & $\begin{array}{l}00 \\
0 \\
0 \\
\Sigma\end{array}$ & \begin{tabular}{l|}
0 \\
00 \\
0 \\
$\vdots$ \\
$\Sigma$
\end{tabular} & $\begin{array}{l}20 \\
\stackrel{0}{0} \\
\stackrel{0}{\Sigma}\end{array}$ & $\begin{array}{l}50 \\
\stackrel{0}{0} \\
\Sigma\end{array}$ & $\begin{array}{l}00 \\
0 \\
0 \\
\\
\Sigma\end{array}$ & & & $\begin{array}{l}\text { so } \\
\frac{\Delta}{0} \\
\dot{0}\end{array}$ & $\begin{array}{l}50 \\
\stackrel{0}{0} \\
\stackrel{2}{\Sigma}\end{array}$ & $\begin{array}{l}\Delta \\
0 \\
\stackrel{0}{2}\end{array}$ & $\begin{array}{l}\circ \\
0 \\
\stackrel{0}{0} \\
\Sigma\end{array}$ & $\begin{array}{l}\text { so } \\
\stackrel{0}{0} \\
\sum \\
\sum\end{array}$ & $\begin{array}{l}\stackrel{5}{0} \\
\stackrel{0}{0} \\
\Sigma\end{array}$ & $\begin{array}{l}\circ \\
0 \\
\vdots \\
\vdots\end{array}$ & : & $\begin{array}{l}50 \\
\stackrel{0}{0} \\
\dot{0}\end{array}$ & $\begin{array}{l}\infty e \\
\stackrel{0}{0} \\
\Sigma\end{array}$ & $\begin{array}{l}\circ \\
\circ \\
0 \\
\Sigma\end{array}$ & $\begin{array}{l}\Delta 8 \\
\frac{0}{0} \\
\dot{0}\end{array}$ & $\begin{array}{l}00 \\
\stackrel{0}{0} \\
\Sigma\end{array}$ & $\begin{array}{l}50 \\
\frac{0}{0} \\
\Sigma\end{array}$ \\
\hline 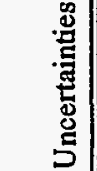 & & & 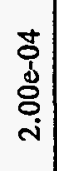 & 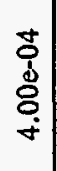 & & 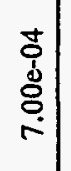 & & & & & & & & & 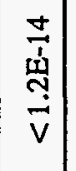 & $\begin{array}{l}8 \\
+ \\
+ \\
8 \\
8 \\
-\end{array}$ & & & & & \\
\hline 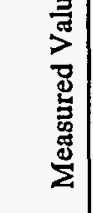 & 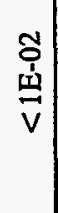 & 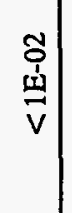 & 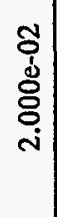 & $\begin{array}{l}\text { Oे } \\
\dot{8} \\
\stackrel{8}{8} \\
\dot{+}\end{array}$ & 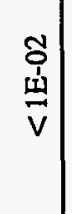 & 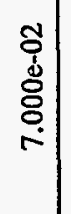 & 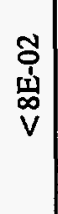 & $\begin{array}{l}\text { ô } \\
\stackrel{+}{4} \\
\vec{v}\end{array}$ & $\begin{array}{l}\text { ô } \\
\text { dै } \\
\text { v }\end{array}$ & $\begin{array}{l}\text { ơ } \\
\text { 山ै } \\
\text { V }\end{array}$ & 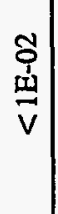 & 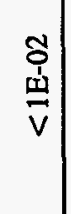 & $\begin{array}{c}\text { 安 } \\
\stackrel{\dot{q}}{\mathrm{v}} \\
\mathrm{v}\end{array}$ & 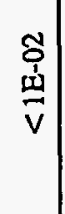 & 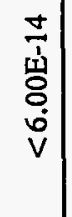 & $\begin{array}{c}\overline{0} \\
+ \\
0 \\
0 \\
0 \\
0 \\
0\end{array} \mid$ & 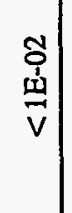 & 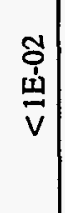 & $\begin{array}{l}\text { ơ } \\
\text { ⿶凵 } \\
\text { ปे }\end{array}$ & 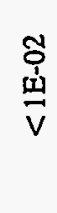 & 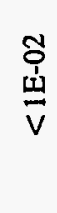 \\
\hline 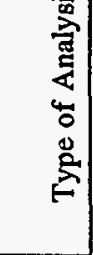 & 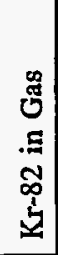 & $\begin{array}{l}\infty \\
5 \\
5 \\
. \Xi \\
0 \\
0 \\
0 \\
5\end{array}$ & 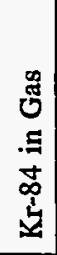 & 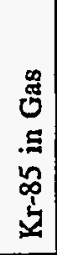 & 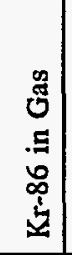 & 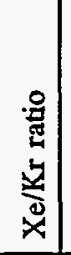 & 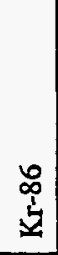 & 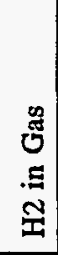 & $\begin{array}{l}0 \\
\tilde{J} \\
. \Xi \\
\delta \\
\delta\end{array}$ & $\begin{array}{l}0 \\
\tilde{J} \\
.5 \\
0 \\
0\end{array}$ & 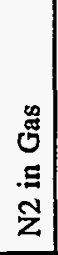 & 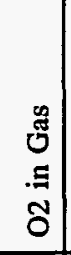 & 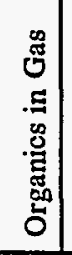 & $\begin{array}{l}0 \\
0 \\
: \Xi \\
0 \\
\pm\end{array}$ & 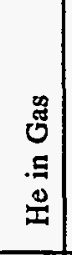 & 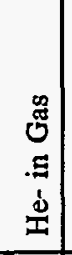 & 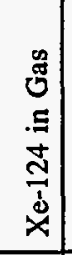 & 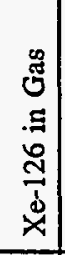 & 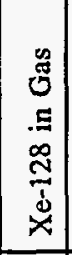 & 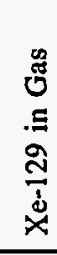 & 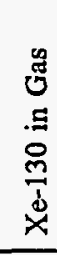 \\
\hline 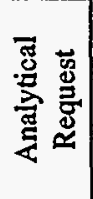 & & & & & & & & & & & & & & & & 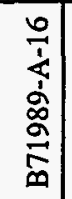 & 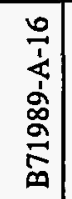 & 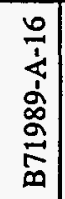 & 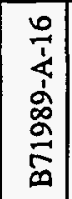 & 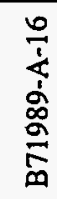 & 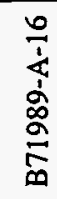 \\
\hline $\begin{array}{l}\text { 岕 } \\
\text { 总 } \\
\text { है }\end{array}$ & ఏ్ & 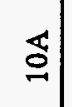 & $\Phi$ & 楁 & $\overleftarrow{\Xi}$ & $\Phi$ & 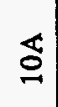 & $\$$ & $\Phi$ & $\$$ & 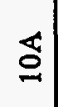 & $\$$ & 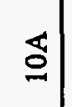 & $\overleftarrow{0}$ & 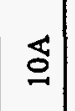 & త్రీ & $\underset{\Xi}{\Phi}$ & 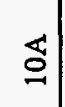 & త્વ & 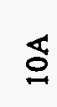 & 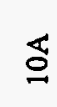 \\
\hline : & $\begin{array}{l}0 \\
0 \\
0 \\
\vdots \\
\Sigma\end{array}$ & 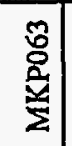 & 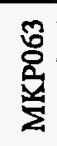 & 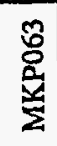 & 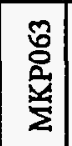 & 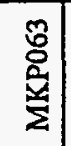 & $\begin{array}{l}\mathscr{0} \\
\dot{0} \\
\Sigma\end{array}$ & 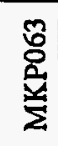 & 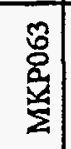 & $\begin{array}{l}\hat{\sigma} \\
\text { 离 } \\
z\end{array}$ & 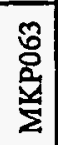 & $\begin{array}{l}0 \\
0 \\
0 \\
\end{array}$ & 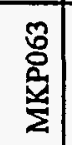 & $\begin{array}{l}0 \\
8 \\
0 \\
2 \\
2\end{array}$ & $\begin{array}{l} \\
0 \\
0 \\
0 \\
\Sigma\end{array}$ & \begin{tabular}{|l|} 
\\
\\
0 \\
0 \\
$\Sigma$ \\
$\Sigma$
\end{tabular} & 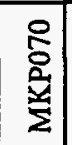 & $\begin{array}{l} \\
8 \\
0 \\
\vdots \\
\Sigma\end{array}$ & 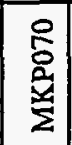 & 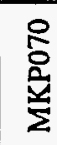 & 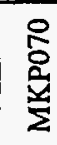 \\
\hline 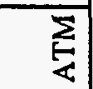 & 苛 & 吉 & 芩 & 苛 & \& & $\underset{\sim}{ \pm}$ & $\underset{-}{\stackrel{D}{O}}$ & ఫ્ & 苍 & 吉 & 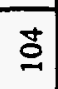 & $\stackrel{+}{0}$ & $\stackrel{+}{0}$ & 巳 & $\stackrel{+}{0}$ & $\stackrel{ \pm}{\circ}$ & $\stackrel{+}{0}$ & 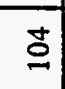 & $\stackrel{ \pm}{\Xi}$ & 으 & ષ્ \\
\hline
\end{tabular}


Table B.1. (contd)

\begin{tabular}{|c|c|c|c|c|c|c|c|c|c|}
\hline ATM & Rod & Section & $\begin{array}{l}\text { Sample } \\
\text { Number }\end{array}$ & $\begin{array}{l}\text { Analytical } \\
\text { Request }\end{array}$ & Type of Analysis & Measured Value & Uncertainties & $\begin{array}{l}\text { Measured } \\
\text { Value Units }\end{array}$ & $\begin{array}{c}\text { Date } \\
\text { Measured }\end{array}$ \\
\hline 104 & MKP070 & & $10 \mathrm{~A}$ & B71989-A-16 & $\mathrm{Xe}-131$ in Gas & $1.000 \mathrm{e}-01$ & $1.00 \mathrm{e}-03$ & Mole \% & $07 / 13 / 88$ \\
\hline 104 & MKP070 & & $10 \mathrm{~A}$ & B71989-A-16 & $\mathrm{Xe}-132$ in Gas & $2.900 \mathrm{e}-01$ & $3.00 \mathrm{e}-03$ & Mole \% & $07 / 13 / 88$ \\
\hline 104 & MKP070 & & $10 \mathrm{~A}$ & B71989-A-16 & $\mathrm{Xe}-134$ in Gas & $3.800 \mathrm{e}-01$ & $4.00 \mathrm{e}-03$ & Mole \% & $07 / 13 / 88$ \\
\hline 104 & MKP070 & & $10 \mathrm{~A}$ & B71989-A-16 & $\mathrm{Xe}-136$ in Gas & $5.700 \mathrm{e}-01$ & $6.00 \mathrm{e}-03$ & Mole \% & $07 / 13 / 88$ \\
\hline 104 & MKP070 & & $10 \mathrm{~A}$ & B71989-A-16 & $\mathrm{Kr}$ in $\mathrm{Gas}$ & $1.100 \mathrm{e}-01$ & & Mole \% & $07 / 13 / 88$ \\
\hline 104 & MKP070 & & $10 \mathrm{~A}$ & B71989-A-16 & $\mathrm{Kr}-78$ in Gas & $<1 \mathrm{E}-02$ & & Mole \% & $07 / 13 / 88$ \\
\hline 104 & MKP070 & & $10 \mathrm{~A}$ & B71989-A-16 & $\mathrm{Kr}-80$ in Gas & $<1 \mathrm{E}-02$ & & Mole \% & $07 / 13 / 88$ \\
\hline 104 & MKP070 & & $10 \mathrm{~A}$ & B71989-A-16 & $\mathrm{Kr}-82$ in Gas & $<1 \mathrm{E}-02$ & & Mole \% & $07 / 13 / 88$ \\
\hline 104 & MKP070 & & $10 \mathrm{~A}$ & B71989-A-16 & $\mathrm{Kr}-83$ in Gas & $1.000 \mathrm{e}-02$ & $1.00 \mathrm{e}-04$ & Mole \% & $07 / 13 / 88$ \\
\hline 104 & MKP070 & & $10 \mathrm{~A}$ & B71989-A-16 & $\mathrm{Kr}-84$ in Gas & $4.000 \mathrm{e}-02$ & $4.00 \mathrm{e}-04$ & Mole \% & $07 / 13 / 88$ \\
\hline 104 & MKP070 & & $10 \mathrm{~A}$ & B71989-A-16 & $\mathrm{Kr}-85$ in Gas & $<1 \mathrm{E}-02$ & & Mole \% & $07 / 13 / 88$ \\
\hline 104 & MKP070 & & $10 \mathrm{~A}$ & B71989-A-16 & $\mathrm{Kr}-86$ in Gas & $6.000 \mathrm{e}-02$ & $6.00 \mathrm{e}-04$ & Mole \% & $07 / 13 / 88$ \\
\hline 104 & MKP070 & & $10 \mathrm{~A}$ & B71989-A-16 & $\mathrm{Xe} / \mathrm{Kr}$ ratio & $1.220 \mathrm{e}+01$ & & & $07 / 13 / 88$ \\
\hline 104 & MKP070 & & $10 \mathrm{~A}$ & B71989-A-16 & $\mathrm{Ar}$ in Gas & $<1 \mathrm{E}-02$ & & Mole \% & $07 / 13 / 88$ \\
\hline 104 & MKP070 & & $10 \mathrm{~A}$ & B71989-A-16 & $\mathrm{H} 2$ in Gas & $<1 \mathrm{E}-02$ & & Mole \% & $07 / 13 / 88$ \\
\hline 104 & MKP070 & & $10 \mathrm{~A}$ & B71989-A-16 & $\mathrm{CO} 2$ in Gas & $<1 \mathrm{E}-02$ & & Mole \% & $07 / 13 / 88$ \\
\hline 104 & MKP070 & & $10 \mathrm{~A}$ & B71989-A-16 & $\mathrm{CO}$ in Gas & $<1 \mathrm{E}-02$ & & Mole \% & $07 / 13 / 88$ \\
\hline 104 & MKP070 & & $10 \mathrm{~A}$ & B71989-A-16 & $\mathrm{N} 2$ in Gas & $<1 \mathrm{E}-02$ & & Mole \% & $07 / 13 / 88$ \\
\hline 104 & MKP070 & & $10 \mathrm{~A}$ & B71989-A-16 & $\mathrm{O} 2$ in Gas & $<1 \mathrm{E}-02$ & & Mole \% & $07 / 13 / 88$ \\
\hline 104 & MKP070 & & $10 \mathrm{~A}$ & B71989-A-16 & Organics in Gas & $<1 \mathrm{E}-02$ & & Mole \% & $07 / 13 / 88$ \\
\hline 104 & MKP070 & & $10 \mathrm{~A}$ & B71989-A-16 & ${ }^{14} \mathrm{C}$ in Gas & $9.730 \mathrm{e}-13$ & & $\mathrm{Ci} / \mathrm{g}$ & $08 / 03 / 88$ \\
\hline
\end{tabular}




\begin{tabular}{|c|c|c|c|c|c|c|c|c|c|c|c|c|c|c|c|c|c|c|c|c|c|}
\hline 总 & & & & & $\stackrel{\infty}{\equiv}$ & $\stackrel{\infty}{\Xi}$ & $\stackrel{\infty}{\equiv}$ & $\stackrel{\infty}{\equiv}$ & $\stackrel{\infty}{=}$ & $\stackrel{\infty}{\equiv}$ & $\stackrel{\infty}{\equiv}$ & $\stackrel{\infty}{\stackrel{\infty}{\sigma}}$ & $\stackrel{\infty}{\equiv}$ & $\stackrel{\infty}{=}$ & $\stackrel{\infty}{\equiv}$ & $\stackrel{\infty}{\Xi}$ & $\stackrel{\infty}{\stackrel{\infty}{\sigma}}$ & $\stackrel{\infty}{=}$ & $\stackrel{\infty}{=}$ & 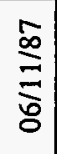 & $\stackrel{\infty}{\equiv}$ \\
\hline 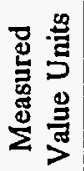 & & & & & $\begin{array}{l}80 \\
\frac{\omega}{0} \\
\grave{2}\end{array}$ & $\begin{array}{l}09 \\
\frac{0}{0} \\
\Sigma\end{array}$ & $\begin{array}{l}\infty 8 \\
\frac{0}{0} \\
\Sigma\end{array}$ & $\begin{array}{l}\Delta 8 \\
\frac{0}{0} \\
\Sigma\end{array}$ & $\begin{array}{l}\infty \\
\frac{0}{0} \\
\sum\end{array}$ & $\begin{array}{l}\Delta \\
0 \\
\stackrel{0}{0} \\
\Sigma\end{array}$ & $\begin{array}{l}\text { so } \\
\frac{0}{0} \\
\Sigma\end{array}$ & $\begin{array}{l}5 \\
\frac{0}{0} \\
\Sigma\end{array}$ & $\begin{array}{l}\infty \\
\frac{0}{0} \\
\sum\end{array}$ & 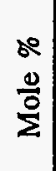 & $\begin{array}{l}0 \\
0 \\
\stackrel{0}{0}\end{array}$ & $\begin{array}{l}00 \\
\frac{0}{0} \\
\Sigma\end{array}$ & $\begin{array}{l}s e \\
\frac{0}{0} \\
\Sigma\end{array}$ & $\begin{array}{l}\Delta 0 \\
\frac{0}{0} \\
\Sigma\end{array}$ & $\begin{array}{l}\Delta 0 \\
\frac{0}{0} \\
\Sigma\end{array}$ & $\begin{array}{l}\Delta 0 \\
\frac{0}{0} \\
\Sigma\end{array}$ & $\begin{array}{l}\text { of } \\
\frac{0}{0} \\
\Sigma\end{array}$ \\
\hline 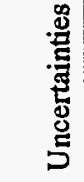 & & & & & $\begin{array}{l}\bar{c} \\
\vdots \\
0 \\
\stackrel{0}{i} \\
i\end{array}$ & $\begin{array}{l}\bar{o} \\
\dot{d} \\
8 \\
i \\
\text { i }\end{array}$ & & & 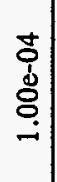 & & 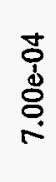 & $\begin{array}{l}0 \\
0 \\
\vdots \\
0 \\
0 \\
\infty\end{array}$ & 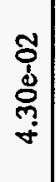 & 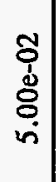 & 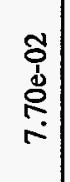 & & & & & 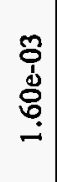 & 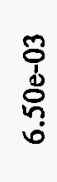 \\
\hline 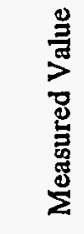 & & & & & $\begin{array}{l}\overrightarrow{0} \\
+ \\
0 \\
o \\
0 \\
0 \\
\end{array}$ & $\begin{array}{l}\overrightarrow{0} \\
+ \\
0 \\
5 \\
5 \\
-\end{array}$ & 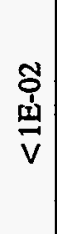 & 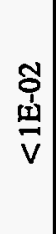 & 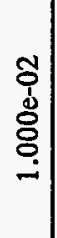 & 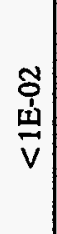 & 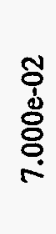 & $\begin{array}{c}\bar{\phi} \\
\grave{d} \\
\stackrel{0}{0} \\
\infty \\
\infty\end{array}$ & $\begin{array}{l}8 \\
+ \\
+ \\
0 \\
\stackrel{0}{0} \\
+ \\
\dot{+}\end{array}$ & 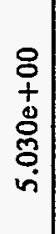 & $\begin{array}{l}8 \\
+ \\
+ \\
0 \\
8 \\
⿱ 亠 䒑 \\
i\end{array}$ & \begin{tabular}{l}
8 \\
+ \\
+ \\
0 \\
0 \\
0 \\
\hdashline \\
-1
\end{tabular} & 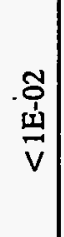 & 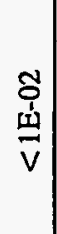 & 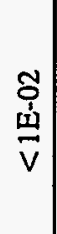 & $\begin{array}{l}\overline{0} \\
\dot{d} \\
\delta \\
0 \\
0 \\
-1\end{array}$ & 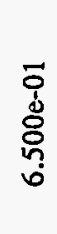 \\
\hline 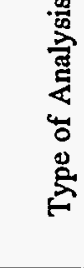 & 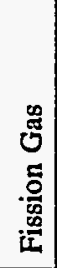 & 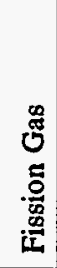 & 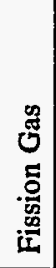 & & $\begin{array}{l}0 \\
0 \\
.5 \\
.5 \\
0 \\
0\end{array}$ & 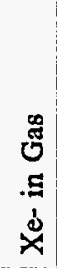 & 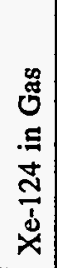 & 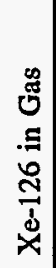 & 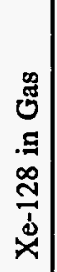 & 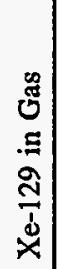 & 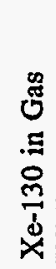 & 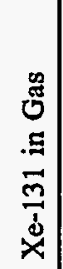 & 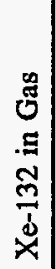 & 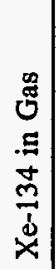 & 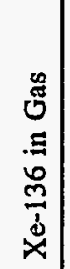 & $\begin{array}{l}\text { D } \\
\tilde{J} \\
. \Xi \\
\vdots\end{array}$ & 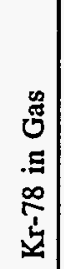 & 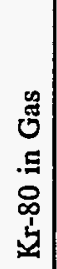 & 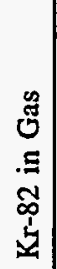 & 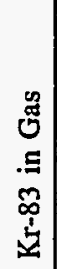 & 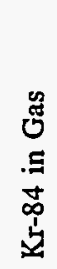 \\
\hline 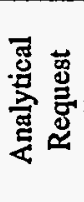 & 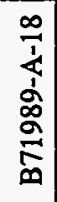 & 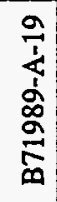 & 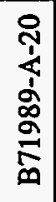 & & 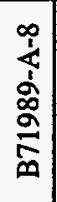 & 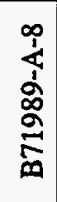 & 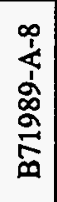 & 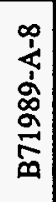 & 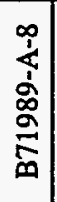 & 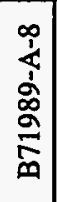 & 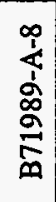 & 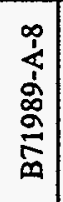 & 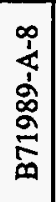 & 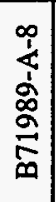 & 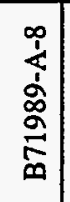 & 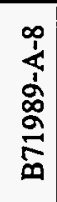 & 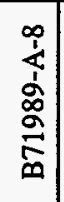 & 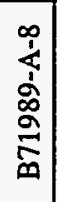 & 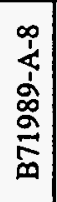 & 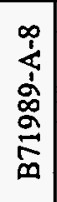 & 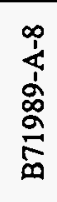 \\
\hline 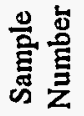 & $\$$ & $\stackrel{8}{8}$ & 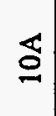 & $\$$ & త్ర & $\Phi$ & తీ & 狤 & 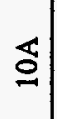 & 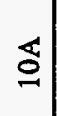 & 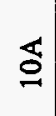 & ऽీ & 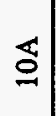 & 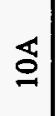 & $\overleftarrow{\Xi}$ & 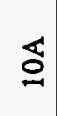 & ఏ & ఠ్ & త్ర & ఏ્త & $\Xi$ \\
\hline 范 & $\begin{array}{l}\vec{o} \\
\overline{\mathbf{o}} \\
\overline{\mathbf{z}} \\
\bar{z}\end{array}$ & $\begin{array}{l}\overrightarrow{0} \\
\stackrel{0}{0} \\
\underline{\Sigma} \\
\Sigma\end{array}$ & $\begin{array}{l}\widehat{\infty} \\
0 \\
\stackrel{1}{\Sigma} \\
\Sigma\end{array}$ & $\begin{array}{l}\stackrel{8}{\circ} \\
\text { 总 } \\
\text { z }\end{array}$ & $\begin{array}{l}\text { 号 } \\
\text { 鱼 }\end{array}$ & $\begin{array}{l}\stackrel{n}{\hat{\partial}} \\
\text { مि } \\
z\end{array}$ & 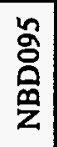 & 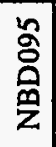 & 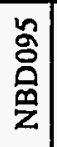 & $\begin{array}{l}\text { 영 } \\
\text { 鱼 }\end{array}$ & 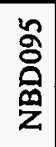 & 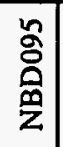 & $\begin{array}{l}\text { 冾 } \\
\text { 商 }\end{array}$ & $\begin{array}{l}\text { 号 } \\
\text { 受 }\end{array}$ & 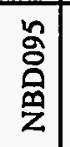 & $\begin{array}{l}\text { 号 } \\
\text { مิ } \\
z\end{array}$ & 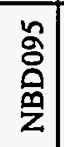 & 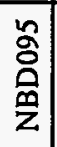 & 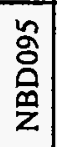 & 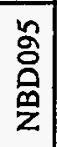 & 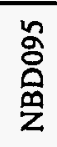 \\
\hline$\sum_{\varepsilon}$ & 总 & 吉 & $\stackrel{+}{\circ}$ & $\nsubseteq$ & $\Xi$ & Ð & 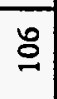 & 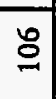 & 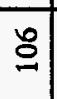 & $\stackrel{8}{\circ}$ & 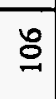 & 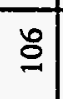 & 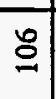 & 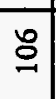 & 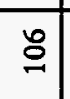 & $\check{\sigma}$ & 号 & 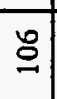 & $\stackrel{\circ}{\circ}$ & ๖ & 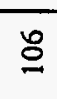 \\
\hline
\end{tabular}




\begin{tabular}{|c|c|c|c|c|c|c|c|c|c|c|c|c|c|c|c|c|c|c|c|c|c|}
\hline 宽 & $\stackrel{\infty}{ٍ}$ & $\stackrel{\infty}{=}$ & 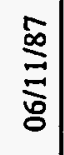 & $\stackrel{\infty}{\vdots}$ & $\stackrel{\infty}{\stackrel{\infty}{\sigma}}$ & 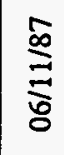 & 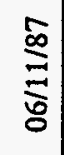 & $\stackrel{\infty}{\stackrel{\infty}{\Xi}}$ & $\stackrel{\infty}{\equiv}$ & $\stackrel{\infty}{\stackrel{\infty}{\Xi}}$ & $\stackrel{\infty}{\stackrel{\infty}{\Xi}}$ & 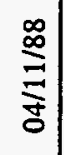 & 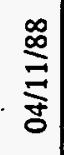 & 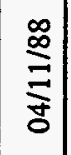 & $\stackrel{\infty}{\stackrel{\infty}{\Xi}}$ & 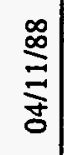 & 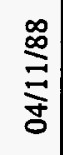 & 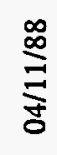 & 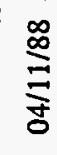 & 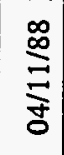 & $\stackrel{\infty}{\stackrel{\infty}{\xi}}$ \\
\hline 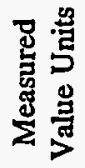 & $\begin{array}{l}08 \\
\stackrel{0}{\circ} \\
\dot{\Sigma}\end{array}$ & 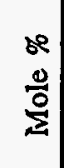 & & $\begin{array}{l}0 \\
0 \\
0 \\
\end{array}$ & $\begin{array}{l}80 \\
\frac{0}{0} \\
\stackrel{0}{\Sigma}\end{array}$ & $\begin{array}{l}s \\
0 \\
0 \\
\Sigma\end{array}$ & $\begin{array}{l}8 e \\
\stackrel{0}{0} \\
\Sigma\end{array}$ & $\begin{array}{l}\infty \\
\frac{0}{0} \\
\stackrel{0}{\Sigma}\end{array}$ & $\begin{array}{l}\Delta e \\
\stackrel{0}{0} \\
\Sigma\end{array}$ & $\begin{array}{l}\infty \\
0 \\
0 \\
\Sigma\end{array}$ & $\frac{8}{8}$ & $\begin{array}{l}\infty \\
0 \\
0 \\
\Sigma\end{array}$ & $\begin{array}{l}\infty \\
0 \\
0 \\
\Sigma\end{array}$ & $\mid \begin{array}{l}80 \\
0 \\
0 \\
\Sigma\end{array}$ & $\begin{array}{l}s \\
0 \\
0 \\
\dot{a}\end{array}$ & $\begin{array}{l}\infty \\
\frac{0}{0} \\
\dot{\Delta}\end{array}$ & $\begin{array}{l}s e \\
\frac{0}{0} \\
\Sigma\end{array}$ & $\begin{array}{l}80 \\
\frac{0}{0} \\
\frac{0}{\Sigma}\end{array}$ & $\begin{array}{l}80 \\
\frac{1}{0} \\
\Sigma\end{array}$ & 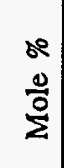 & $\begin{array}{l}\text { se } \\
\frac{D}{0} \\
\frac{0}{\Sigma}\end{array}$ \\
\hline 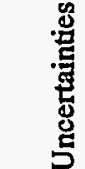 & 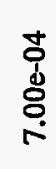 & 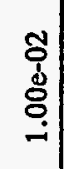 & & $\begin{array}{l}\tilde{\sigma} \\
\vdots \\
\delta \\
\tilde{\sigma} \\
\dot{m}\end{array}$ & & & & & & & & $\begin{array}{l}\overrightarrow{0} \\
\dot{d} \\
\dot{\delta} \\
\dot{0}\end{array}$ & & & & 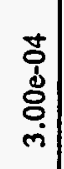 & & $\begin{array}{l}\stackrel{0}{0} \\
\dot{d} \\
\stackrel{5}{-}\end{array}$ & 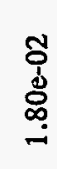 & $\begin{array}{l}\tilde{\delta} \\
\dot{d} \\
\delta \\
0 \\
\infty\end{array}$ & 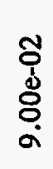 \\
\hline 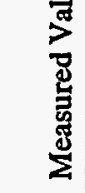 & 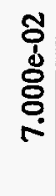 & $\begin{array}{c}\overline{0} \\
\vdots \\
\vdots \\
0 \\
0 \\
0\end{array}$ & $\begin{array}{l}8 \\
+ \\
+ \\
\stackrel{0}{0} \\
⿱ ⺊ \\
0\end{array}$ & 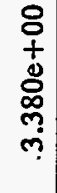 & 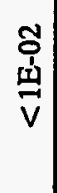 & 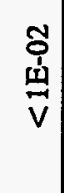 & 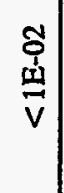 & 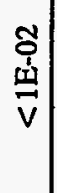 & 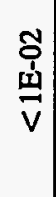 & 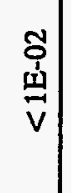 & 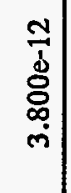 & $\begin{array}{l}\overline{0} \\
+ \\
\mathbf{0} \\
\mathbf{0} \\
0 \\
0\end{array}$ & $\begin{array}{l}\overline{0} \\
+ \\
+ \\
\dot{0} \\
\dot{p} \\
\dot{m}\end{array}$ & 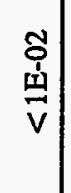 & 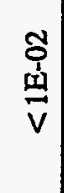 & 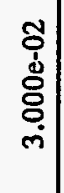 & 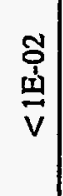 & 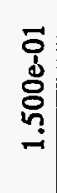 & $\begin{array}{l}8 \\
+ \\
+ \\
0 \\
0 \\
0 \\
0 \\
-1\end{array}$ & 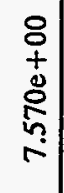 & 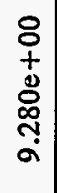 \\
\hline 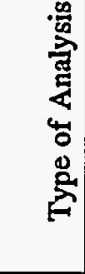 & 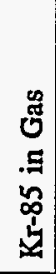 & 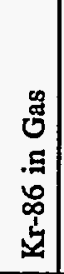 & 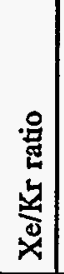 & $\begin{array}{l}\mathscr{9} \\
\tilde{5} \\
.5 \\
4\end{array}$ & 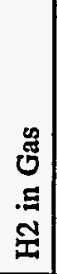 & 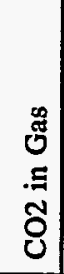 & $\begin{array}{c}0 \\
0 \\
0 \\
. \Xi \\
0 \\
0\end{array}$ & 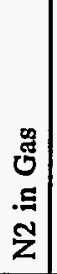 & 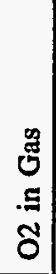 & 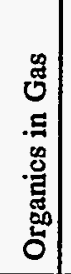 & 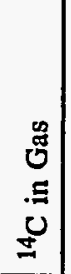 & 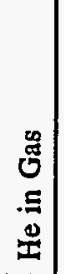 & 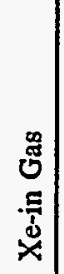 & 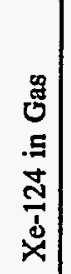 & 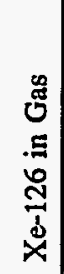 & 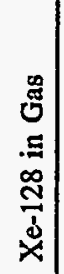 & 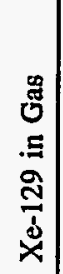 & 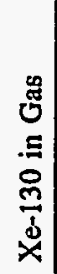 & $\begin{array}{l}\stackrel{\infty}{0} \\
. \\
\bar{m} \\
\vec{d} \\
\dot{d}\end{array}$ & 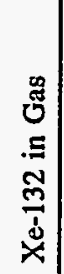 & 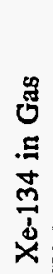 \\
\hline 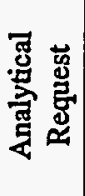 & 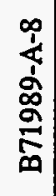 & 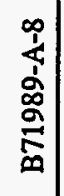 & 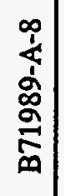 & 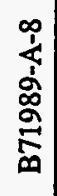 & 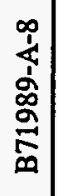 & 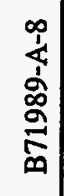 & 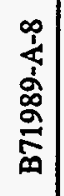 & 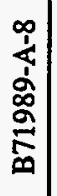 & 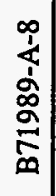 & 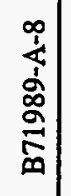 & 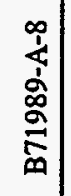 & 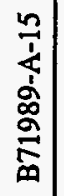 & & 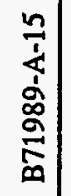 & 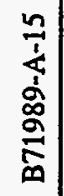 & 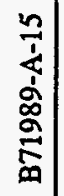 & 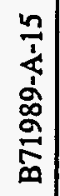 & 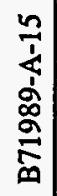 & $\begin{array}{l}\frac{n}{4} \\
\dot{\alpha} \\
\stackrel{\alpha}{\alpha} \\
\stackrel{\infty}{\alpha}\end{array}$ & 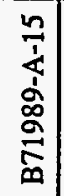 & 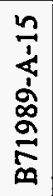 \\
\hline 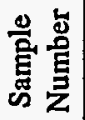 & త్ర & کీ & 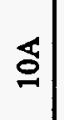 & 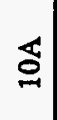 & ડ્ડ & 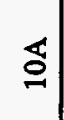 & $\underset{\Xi}{\Phi}$ & ఏ & 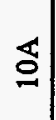 & 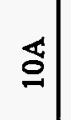 & 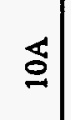 & 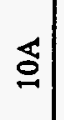 & $\stackrel{\nwarrow}{ذ}$ & ऽ & ذ్ర & $\underset{ీ}{~}$ & $\overleftarrow{\Xi}$ & کీ & 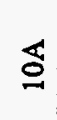 & 顿 & $\$$ \\
\hline 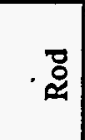 & 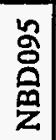 & $\begin{array}{l}\text { 号 } \\
\text { 善 }\end{array}$ & 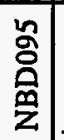 & 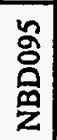 & 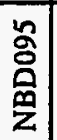 & 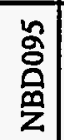 & 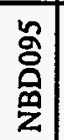 & 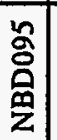 & $\begin{array}{l}\text { nू } \\
\text { 号 } \\
\text { 爱 }\end{array}$ & 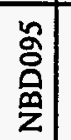 & 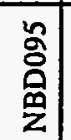 & $\begin{array}{l}\vec{m} \\
\stackrel{9}{\mathbf{n}} \\
\bar{z}\end{array}$ & $\begin{array}{l}\vec{m} \\
\vec{m} \\
\bar{z}\end{array}$ & $\begin{array}{l}\vec{m} \\
\overline{\mathbf{n}}\end{array}$ & $\begin{array}{l}\vec{m} \\
\stackrel{m}{0} \\
z\end{array}$ & $\begin{array}{l}\vec{m} \\
\vec{m} \\
\text { 商 }\end{array}$ & $\begin{array}{l}\bar{m} \\
\overline{\mathrm{g}} \\
\mathrm{g}\end{array}$ & $\begin{array}{l}\vec{m} \\
\stackrel{m}{\mathbf{m}}\end{array}$ & $\begin{array}{l}\vec{m} \\
\stackrel{\vec{a}}{z} \\
\underline{z}\end{array}$ & $\begin{array}{l}\bar{m} \\
\overline{0} \\
\bar{z}\end{array}$ & $\begin{array}{l}\vec{m} \\
\overline{\mathrm{m}} \\
\overline{\mathrm{g}}\end{array}$ \\
\hline$\underset{\langle}{Z}$ & 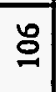 & 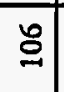 & ஜ & ஜ & 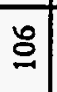 & $\Xi$ & $\stackrel{0}{\circ}$ & Ð & 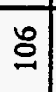 & $\stackrel{2}{\circ}$ & 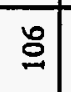 & $\stackrel{\circ}{\circ}$ & ๕ & ஜ & $\stackrel{\square}{0}$ & ঃ & ঃ & ঃ & 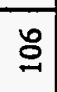 & : & ๖ \\
\hline
\end{tabular}




\begin{tabular}{|c|c|c|c|c|c|c|c|c|c|}
\hline $68 / 92 / 90$ & $\%$ ग०W & & $20-\exists I>$ & $\operatorname{seD} u ! \dagger Z I^{-\theta} \mathrm{X}$ & $s Z-\nabla-686 \mathrm{~L} L \mathrm{~g}$ & YOI & & $90 Z 0 N G V$ & $80 I$ \\
\hline $68 / 9 Z / 90$ & $\%$ әโ०W & & I0+2ISS'9 & sep u! $-2 \mathrm{X}$ & & VOI & & $90 Z 0 N a r$ & $80 I$ \\
\hline $68 / 92 / 90$ & $\%$ गा०W & $10^{-}-200^{\circ} \varepsilon$ & $10+20+s \cdot z$ & sep u! әH & $s Z-\nabla-686 I \angle g$ & VOI & & $90 Z 0 N a V$ & $80 I$ \\
\hline $88 /$ SZ/t0 & $00 / ! 0$ & & I I-ə00I' I & $\operatorname{seg}$ u! $\supset_{t I}$ & SI- $\forall-686$ ILQ & VOI & & IEIवGN & $90 I$ \\
\hline $88 /[I /$ t 0 & $\%$ วए०ผ & & $20-9 I>$ & seפ u! sọuesio & SI-V-686ILg & VOI & & IEIQGN & $90 I$ \\
\hline $88 /[1 / 60$ & \% әा०พ & & 20-GI > & seg u! zo & SI- $\forall-686 I L 8$ & VOI & & IEIGGN & $90 I$ \\
\hline $88 / 1 / / 70$ & $\%$ गโOW & & $20-3 I>$ & seg u! ZN & $S I-\forall-686 I L g$ & $\forall 0 I$ & & IEIGRN & $90 I$ \\
\hline $88 /[I / t 00$ & $\%$ әा०W & & $20-\mathrm{gI}>$ & | & SI-V-686ILg & VOI & & IEIOGN & $90 I$ \\
\hline $88 / I I / t 0$ & $\%$ ә०W & & $20-9 I>$ & seD u! zOJ & SI- -686 ILG & VOI & & IEIवGN & $90 I$ \\
\hline $88 /[I / 70$ & \% गоพ & & $20-\exists I>$ & $\operatorname{seg}$ u! $\mathrm{ZH}$ & SI- $-6886 I L \mathrm{~g}$ & VOI & & IEIGGN & $90 I$ \\
\hline $88 /[I / / 70$ & $\%$ ग०W & $20-20 \operatorname{s}^{\circ} \tau$ & $00+20 I S \cdot 2$ & sed uा x & $S I-\forall-686 I L G$ & VOI & & IEIGGN & $90 I$ \\
\hline $88 / / \mathrm{l} / \mathrm{t} 0$ & & & $00+2000^{\circ} 6$ & 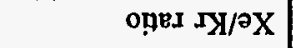 & & VOI & & IEIGGN & $90 I$ \\
\hline $88 / \mathrm{I} / \mathrm{t} 0$ & $\%$ әоК & $z 0^{-}-200^{\circ} z$ & $00+20 \mathrm{I} 6^{\circ} I$ & seD u! 98-ry & SI-V-686ILG & VOI & & IEIGQN & 90I \\
\hline $88 / I I / 70$ & $\%$ गा०W & $\varepsilon 0-20 t^{\prime} I$ & $I 0^{-2} 00 t^{\circ} I$ & sed u! s8-זY & SI-V-686ILg & VOI & & IEIGRN & $90 I$ \\
\hline $88 / \mathrm{I} / /$ t0 & $\%$ әए० & $20-ə 0 Z \cdot I$ & $00+20 Z Z \cdot I$ & SED u! $\downarrow 8-5 Y$ & SI-V-686ILG & VOI & & IEIGgN & $90 I$ \\
\hline $88 / I I / t 0$ & $\%$ गा०स & $\varepsilon 0^{-200^{\circ} \emptyset}$ & I0-ว006 $\mathcal{E}$ & SED U! E8-זY & $S I-\forall-686 I L 8$ & VOI & & I $\varepsilon$ IवgN & 901 \\
\hline $88 / I / / 70$ & $\%$ әроพ & $70-200^{\circ} I$ & $20-2000^{\circ} I$ & seD u! $28-5 y$ & SI-V-686ILg & VOI & & IEIवgN & 901 \\
\hline $88 / I I /$ 0 & $\%$ ә०พ & & 20-GI> & seD u! 08-IX & $S I-\nabla-686 I L G$ & VOI & & IยІดgN & $90 I$ \\
\hline $88 / I I / 70$ & $\%$ गГणW & & $20-\exists I>$ & seg u! $8 L-5 y$ & SI- $\forall-686[L \mathrm{~g}$ & VOI & & IEIवgN & $90 \mathrm{I}$ \\
\hline $88 / I I / t 0$ & $\%$ əІ०W & & $00+20 \angle 9^{\circ} \varepsilon$ & sep u! זי人 & & VOI & & IEIवgN & 901 \\
\hline $88 /[\mathrm{l} / \mathrm{t} 0$ & $\%$ จा०พ & I0-ว0カ๋ I & $I 0+20 Z t^{\cdot} I$ & seD u! $9 \varepsilon I^{-ə} \mathrm{X}$ & $S I-\forall-686$ L L8 & VOI & & IEโGgN & $90 I$ \\
\hline $\begin{array}{l}\text { pasnseəw } \\
\text { әנеव }\end{array}$ & 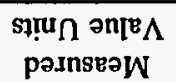 & sə̣ur!eนlaoun & 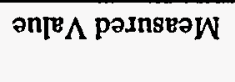 & sṭ $\kappa_{[} \mathrm{eur}$ jo $2 \mathrm{~d} \kappa_{\mathrm{I}}$ & 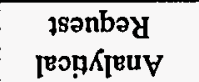 & $\begin{array}{l}\text { JaquinN } \\
\text { ə|dures }\end{array}$ & uop̣oas & poy & WLV \\
\hline
\end{tabular}

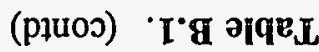


Table B.1. (contd)

\begin{tabular}{|c|c|c|c|c|c|c|c|c|c|}
\hline ATM & Rod & Section & $\begin{array}{l}\text { Sample } \\
\text { Number }\end{array}$ & $\begin{array}{c}\text { Analytical } \\
\text { Request }\end{array}$ & Type of Analysis & Measured Value & Uncertainties & $\begin{array}{c}\text { Measured } \\
\text { Value Units }\end{array}$ & $\begin{array}{c}\text { Date } \\
\text { Measured }\end{array}$ \\
\hline 108 & ADN0206 & & $10 \mathrm{~A}^{\circ}$ & B71989-A-25 & $\mathrm{Xe}-126$ in Gas & $<1 \mathrm{E}-02$ & & Mole \% & $06 / 26 / 89$ \\
\hline 108 & ADN0206 & & $10 \mathrm{~A}$ & B71989-A-25 & $\mathrm{Xe}-128$ in Gas & $2.000 \mathrm{e}-02$ & $2.00 \mathrm{e}-04$ & Mole $\%$ & $06 / 26 / 89$ \\
\hline 108 & ADN0206 & & $10 \mathrm{~A}$ & B71989-A-25 & $\mathrm{Xe}-129$ in Gas & $<1 \mathrm{E}-02$ & & Mole \% & $06 / 26 / 89$ \\
\hline 108 & ADN0206 & & $10 \mathrm{~A}$ & B71989-A-25 & $\mathrm{Xe}-130$ in Gas & $1.000 \mathrm{e}-01$ & $1.00 \mathrm{e}-03$ & Mole \% & $06 / 26 / 89$ \\
\hline 108 & ADN0206 & & $10 \mathrm{~A}$ & B71989-A-25 & $\mathrm{Xe}-131$ in Gas & $6.090 e+00$ & $6.10 \mathrm{e}-02$ & Mole \% & $06 / 26 / 89$ \\
\hline 108 & ADN0206 & & $10 \mathrm{~A}$ & B71989-A-25 & $\mathrm{Xe}-132$ in Gas & $1.370 \mathrm{e}+01$ & $1.40 \mathrm{e}-01$ & Mole \% & $06 / 26 / 89$ \\
\hline 108 & ADN0206 & & $10 \mathrm{~A}$ & B71989-A-25 & $\mathrm{Xe}-134$ in Gas & $1.980 e+01$ & $2.00 \mathrm{e}-01$ & Mole \% & $06 / 26 / 89$ \\
\hline 108 & ADN0206 & & $10 \mathrm{~A}$ & B71989-A-25 & $\mathrm{Xe}-136$ in Gas & $2.580 e+01$ & $2.60 \mathrm{e}-01$ & Mole \% & $06 / 26 / 89$ \\
\hline 108 & ADN0206 & & $10 \mathrm{~A}$ & B71989-A-25 & $\mathrm{Kr}$ in Gas & $8.160 e+00$ & & Mole \% & $06 / 26 / 89$ \\
\hline 108 & ADN0206 & & $10 \mathrm{~A}$ & B71989-A-25 & $\mathrm{Kr}-78$ in Gas & $<1 \mathrm{E}-02$ & & Mole \% & $06 / 26 / 89$ \\
\hline 108 & ADN0206 & & $10 \mathrm{~A}$ & B71989-A-25 & $\mathrm{Kr}-80$ in Gas & $<1 \mathrm{E}-02$ & & Mole \% & $06 / 26 / 89$ \\
\hline 108 & ADN0206 & & $10 \mathrm{~A}$ & B71989-A-25 & $\mathrm{Kr}-82$ in Gas & $1.000 \mathrm{e}-02$ & $1.00 \mathrm{e}-04$ & Mole \% & $06 / 26 / 89$ \\
\hline .108 & ADN0206 & & $10 \mathrm{~A}$ & B71989-A-25 & $\mathrm{Kr}-83$ in Gas & $9.900 \mathrm{e}-01$ & $1.00 \mathrm{e}-03$ & Mole \% & $06 / 26 / 89$ \\
\hline 108 & ADN0206 & & $10 \mathrm{~A}$ & B71989-A-25 & $\mathrm{Kr}-84$ in Gas & $2.570 \mathrm{e}+00$ & $2.60 \mathrm{e}-02$ & Mole \% & $06 / 26 / 89$ \\
\hline 108 & ADN0206 & & $10 \mathrm{~A}$ & B71989-A-25 & $\mathrm{Kr}-85$ in Gas & $2.800 \mathrm{e}-01$ & $2.80 \mathrm{e}-03$ & Mole \% & $06 / 26 / 89$ \\
\hline 108 & ADN0206 & & $10 \mathrm{~A}$ & B71989-A-25 & $\mathrm{Kr}-86$ in Gas & $4.310 e+00$ & $4.30 \mathrm{e}-02$ & Mole \% & $06 / 26 / 89$ \\
\hline 108 & ADN0206 & & $10 \mathrm{~A}$ & B71989-A-25 & $\mathrm{Xe} / \mathrm{Kr}$ ratio & $8.028 \mathrm{e}+00$ & & & $06 / 26 / 89$ \\
\hline 108 & ADN0206 & & $10 \mathrm{~A}$ & B71989-A-25 & Ar in Gas & $1.000 \mathrm{e}-02$ & $1.00 \mathrm{e}-04$ & Mole \% & $06 / 26 / 89$ \\
\hline 108 & ADN0206 & & $10 \mathrm{~A}$ & B71989-A-25 & $\mathrm{H} 2$ in $\mathrm{Gas}$ & $<1 \mathrm{E}-02$ & & Mole \% & $06 / 26 / 89$ \\
\hline 108 & ADN0206 & & $10 \mathrm{~A}$ & B71989-A-25 & $\mathrm{CO} 2$ in Gas & $<1 \mathrm{E}-02$ & & Mole \% & $06 / 26 / 89$ \\
\hline 108 & ADN0206 & & $10 \mathrm{~A}$ & B71989-A-25 & $\mathrm{CO}$ in Gas & $<1 \mathrm{E}-01$ & & Mole \% & $06 / 26 / 89$ \\
\hline
\end{tabular}


Table B.1. (contd)

\begin{tabular}{|c|c|c|c|c|c|c|c|c|c|}
\hline ATM & Rod & Section & $\begin{array}{l}\text { Sample } \\
\text { Number }\end{array}$ & $\begin{array}{l}\text { Analytical } \\
\text { Request }\end{array}$ & Type of Analysis & Measured Value & Uncertainties & $\begin{array}{c}\text { Measured } \\
\text { Value Units }\end{array}$ & $\begin{array}{c}\text { Date } \\
\text { Measured }\end{array}$ \\
\hline 108 & ADN0206 & & $10 \mathrm{~A}$ & B71989-A-25 & N2 in Gas & $7.200 \mathrm{e}-01$ & $7.20 \mathrm{e}-03$ & Mole \% & $06 / 26 / 89$ \\
\hline 108 & ADN0206 & & $10 \mathrm{~A}$ & B71989-A-25 & $\mathrm{O} 2$ in Gas & $1.800 \mathrm{e}-01$ & $1.80 \mathrm{e}-03$ & Mole \% & $06 / 26 / 89$ \\
\hline 108 & ADN0206 & & $10 \mathrm{~A}$ & B71989-A-25 & Organics in Gas & $<1 \mathrm{E}-02$ & & Mole \% & $06 / 26 / 89$ \\
\hline 108 & ADN0206 & & $10 \mathrm{~A}$ & B71989-A-25 & ${ }^{14} \mathrm{C}$ in Gas & $<5.6 \mathrm{E}-12$ & $<1 \mathrm{E}-12$ & $\mathrm{Ci} / \mathrm{cc}$ & $07 / 13 / 89$ \\
\hline 108 & ADN0206 & & 10B & B71989-A-26 & $\mathrm{He}$ in Gas & $2.570 \mathrm{e}+01$ & $2.60 \mathrm{e}-01$ & Mole \% & $06 / 28 / 89$ \\
\hline 108 & ADN0206 & & $10 \mathrm{~B}$ & & $\mathrm{Xe}-$ in Gas & $6.599 e+01$ & & Mole \% & $06 / 28 / 89$ \\
\hline 108 & ADN0206 & & $10 \mathrm{~B}$ & B71989-A-26 & $\mathrm{Xe}-124$ in Gas & $<1 \mathrm{E}-02$ & & Mole \% & $06 / 28 / 89$ \\
\hline 108 & ADN0206 & & $10 \mathrm{~B}$ & B71989-A-26 & $\mathrm{Xe}-126$ in Gas & $<1 \mathrm{E}-02$ & & Mole \% & $06 / 28 / 89$ \\
\hline 108 & ADN0206 & & $10 \mathrm{~B}$ & B71989-A-26 & $\mathrm{Xe}-128$ in Gas & $2.000 \mathrm{e}-02$ & $2.00 \mathrm{e}-04$ & Mole \% & $06 / 28 / 89$ \\
\hline 108 & ADN0206 & & $10 B$ & B71989-A-26 & $\mathrm{Xe}-129$ in Gas & $<1$ E-02 & & Mole \% & $06 / 28 / 89$ \\
\hline 108 & ADN0206 & & 10B & B71989-A-26 & $\mathrm{Xe}-130$ in Gas & $1.100 \mathrm{e}-01$ & $1.10 \mathrm{e}-03$ & Mole \% & $06 / 28 / 89$ \\
\hline 108 & ADN0206 & & $10 \mathrm{~B}$ & B71989-A-26 & $\mathrm{Xe}-131$ in Gas & $6.160 \mathrm{e}+00$ & $6.20 \mathrm{e}-02$ & Mole \% & $06 / 28 / 89$ \\
\hline 108 & ADN0206 & & 10B & B71989-A-26 & $\mathrm{Xe}-132$ in Gas & $1.380 \mathrm{e}+01$ & $1.40 \mathrm{e}-01$ & Mole \% & $06 / 28 / 89$ \\
\hline 108 & ADN0206 & & $10 \mathrm{~B}$ & B71989-A-26 & $\mathrm{Xe}-134$ in Gas & $2.000 \mathrm{e}+01$ & $2.00 \mathrm{e}-01$ & Mole \% & $06 / 28 / 89$ \\
\hline 108 & ADN0206 & & $10 \mathrm{~B}$ & B71989-A-26 & $\mathrm{Xe}-136$ in Gas & $2.590 \mathrm{e}+01$ & $2.60 \mathrm{e}-01$ & Mole \% & $06 / 28 / 89$ \\
\hline 108 & ADN0206 & & $10 \mathrm{~B}$ & B71989-A-26 & $\mathrm{Kr}$ in Gas & $8.230 \mathrm{e}+00$ & & Mole \% & $06 / 28 / 89$ \\
\hline 108 & ADN0206 & & $10 \mathrm{~B}$ & B71989-A-26 & $\mathrm{Kr}-78$ in Gas & $<1 \mathrm{E}-02$ & & Mole \% & $06 / 28 / 89$ \\
\hline 108 & ADN0206 & & $10 \mathrm{~B}$ & B71989-A-26 & $\mathrm{Kr}-80$ in Gas & $<1 \mathrm{E}-02$ & & Mole \% & $06 / 28 / 89$ \\
\hline 108 & ADN0206 & & $10 \mathrm{~B}$ & B71989-A-26 & $\mathrm{Kr}-82$ in Gas & $1.000 \mathrm{e}-02$ & $1.00 \mathrm{e}-04$ & Mole \% & $06 / 28 / 89$ \\
\hline 108 & ADN0206 & & $10 \mathrm{~B}$ & B71989-A-26 & $\mathrm{Kr}-83$ in Gas & $9.900 \mathrm{e}-01$ & $1.00 \mathrm{e}-02$ & Mole \% & $06 / 28 / 89$ \\
\hline 108 & ADN0206 & & $10 B$ & B71989-A-26 & $\mathrm{Kr}-84$ in Gas & $2.600 e+00$ & $2.60 \mathrm{e}-02$ & Mole \% & $06 / 28 / 89$ \\
\hline
\end{tabular}




\begin{tabular}{|c|c|c|c|c|c|c|c|c|c|c|c|c|c|c|}
\hline 苞 & $\begin{array}{l}\stackrel{a}{0} \\
\stackrel{\infty}{*} \\
\stackrel{0}{\delta}\end{array}$ & 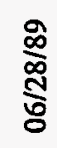 & 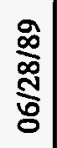 & 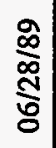 & 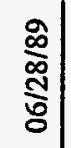 & 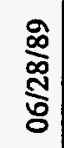 & 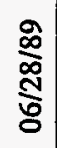 & $\begin{array}{l}\stackrel{0}{0} \\
\stackrel{0}{0} \\
\stackrel{0}{0} \\
0\end{array}$ & 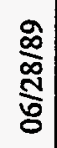 & 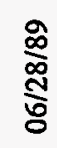 & 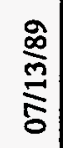 & & & \\
\hline 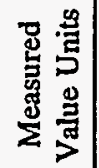 & $\begin{array}{l}x \\
\stackrel{0}{0} \\
\stackrel{0}{\Sigma}\end{array}$ & $\begin{array}{l}\text { se } \\
\stackrel{0}{0} \\
\dot{0}\end{array}$ & & $\begin{array}{l}\Delta 8 \\
\frac{0}{0} \\
\stackrel{0}{\Sigma}\end{array}$ & $\begin{array}{l}80 \\
\frac{0}{0} \\
\grave{\Sigma}\end{array}$ & $\begin{array}{l}80 \\
\frac{0}{0} \\
\stackrel{2}{2}\end{array}$ & $\begin{array}{l}\Delta 8 \\
\frac{0}{0} \\
\Sigma\end{array}$ & $\begin{array}{l}\text { se } \\
\stackrel{0}{0} \\
\Sigma\end{array}$ & 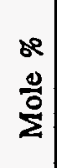 & $\begin{array}{l}80 \\
\stackrel{0}{0} \\
\Sigma\end{array}$ & $\frac{8}{0}$ & & & \\
\hline 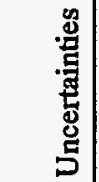 & 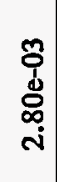 & $\begin{array}{l}\tilde{\delta} \\
\dot{\delta} \\
\dot{+} \\
\dot{+} \\
\dot{f}\end{array}$ & 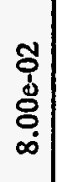 & & & & & & & & 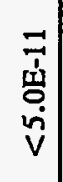 & & & \\
\hline 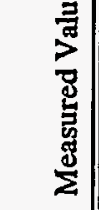 & $\begin{array}{l}\bar{\delta} \\
\dot{\delta} \\
\delta \\
0 \\
i\end{array}$ & 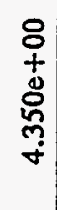 & $\begin{array}{l}8 \\
+ \\
+ \\
\delta \\
0 \\
\infty \\
\infty\end{array}$ & $\begin{array}{c}\text { 号 } \\
\text { ثี } \\
\vec{v}\end{array}$ & $\begin{array}{l}\text { Oे } \\
\vdots \\
\text { İ } \\
\text { v }\end{array}$ & 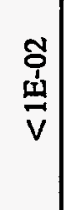 & 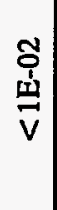 & 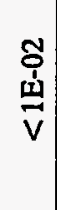 & 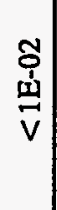 & 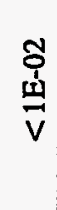 & $\begin{array}{c}\stackrel{0}{1} \\
\mathfrak{w} \\
\\
\vec{v}\end{array}$ & & & \\
\hline 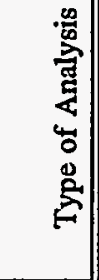 & 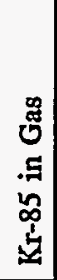 & 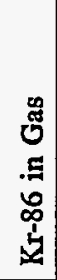 & 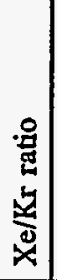 & $\begin{array}{c}0 \\
0 \\
0 \\
\Xi \\
\vdots \\
\end{array}$ & $\begin{array}{l}0 \\
5 \\
\Xi \\
.5 \\
\mathbb{2}\end{array}$ & 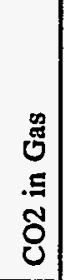 & $\begin{array}{c}\mathscr{g} \\
\tilde{5} \\
. \Xi \\
0 \\
0\end{array}$ & $\begin{array}{l}\tilde{g} \\
\tilde{J} \\
. \Xi \\
\tilde{z}\end{array}$ & 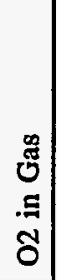 & 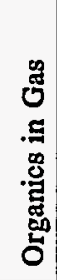 & $\begin{array}{l}0 \\
0 \\
.5 \\
0 \\
0 \\
\Xi\end{array}$ & 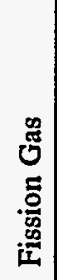 & 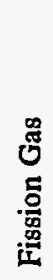 & 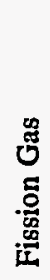 \\
\hline 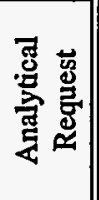 & 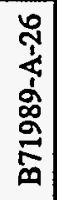 & 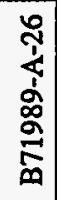 & & 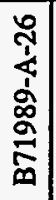 & 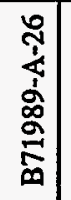 & 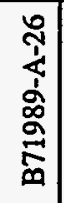 & 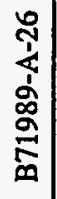 & 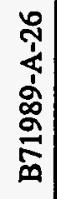 & 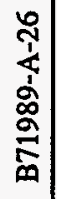 & 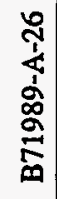 & 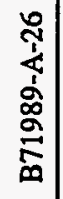 & 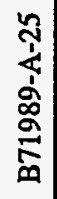 & 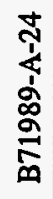 & 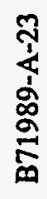 \\
\hline 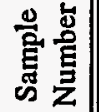 & 电 & 号 & 号 & 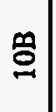 & 号 & $\stackrel{\infty}{0}$ & $\stackrel{\circ}{\circ}$ & $\stackrel{\mathscr{s}}{\circ}$ & 号 & 号 & 号 & & & \\
\hline $\begin{array}{l}\overrightarrow{0} \\
\mathscr{a}\end{array}$ & 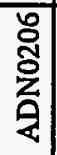 & 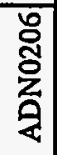 & 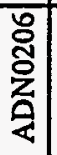 & 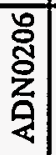 & 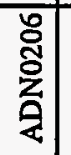 & 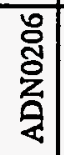 & 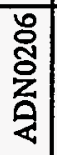 & 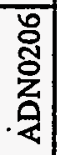 & 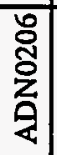 & 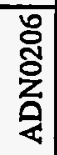 & 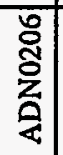 & 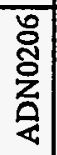 & $\frac{m}{2}$ & 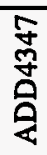 \\
\hline$\underset{⿱ 乛 龰}{\mid}$ & $\stackrel{\infty}{\Xi}$ & $\stackrel{\infty}{\varrho}$ & $\stackrel{\infty}{\circ}$ & $\stackrel{\infty}{0}$ & $\stackrel{\infty}{\circ}$ & $\stackrel{\infty}{\circ}$ & $\stackrel{\infty}{\varrho}$ & $\stackrel{\infty}{\varrho}$ & $\stackrel{\infty}{\circ}$ & $\stackrel{\infty}{\stackrel{9}{9}}$ & $\stackrel{\circ}{\circ}$ & $\stackrel{\infty}{\circ}$ & $\stackrel{\text { o }}{\circ}$ & $\stackrel{\circ}{\circ}$ \\
\hline
\end{tabular}

B.34 


\section{Distribution}

No. of

Copies

Offsite

12 DOE/Office of Scientific and Technical Information

R. S. Moore

Automated Sciences Group, Inc.

800 Oak Ridge Turnpike

Oak Ridge, TN 37830

Department of Energy

Office of Civilian Radioactive Waste

Management

Washington,-D.C. 20585

Attn: A. B. Brownstein

H. J. Hale

W. Lake

W. Lemeshewsky

T. D. Nguyen

P. Finn

Argonne National Laboratory

9700 S. Cass, Bldg. 205

Argonne, IL 60439

K. Gibbard

Department of Energy

Energy Information Administration

1707 H Street, NW

Washington, D.C. 20006

R. W. Lambert

Electric Power Research Institute

P.O. Box 10412

Palo Alto, CA 94303

W. Nodean

Iowa Electric Light and Power Company

P.O. Box 351

Cedar Rapids, IA 52406
No. of

Copies

M. Rahimi

E. R. Johnson Associates, Inc.

9302 Lee Highway

Suite 700

Fairfax, VA 22031

R. B. Stout

Lawrence Livermore National Laboratory

P.O. Box 808

Livermore, CA 94550

Oak Ridge National Laboratory

P.O. Box 2008

Oak Ridge, TN 37831

Attn: A. G. Croff

S. B. Ludwig

C. V. Parks

R. B. Pope

J. W. Roddy

TRW Environmental Safety Systems, Inc.

2650 Park Tower Drive

Suite 800

Vienna, VA 22180-7306

Attn: B. Hodson

W. Standley

D. A. Williamson

P. Gottlieb

TRW Environmental Safety Systems Inc.

101 Convention Center Drive

Suite P-110

Las Vegas, NV 89109

D. Zabransky

Wisconsin Electric Power Company

231 West Michigan Street

Milwaukee, WI 53201

Distr.1 
No. of

Copies

Onsite

2 DOE Richland Operations Office

D. C. Langstaff

Westinghouse Hanford Company

F. M. Coony

\section{Pacific Northwest Laboratory}

D. L. Baldwin, P7-22

D. E. Blahnik (2), P8-10

S. R. Bierman, K8-34

M. F. Cooper, P7-41

M. E. Cunningham, P8-34

R. E. Einziger, P7-14

S. K. Fadeff, P8-08

M. W. Goheen, P7-22

W. J. Gray, P7-14
No. of

Copies

L. R. Greenwood, P7-22

R. J. Guenther (20), P8-34

U. P. Jenquin, K8-34

L. S. Kellogg, P7-22

A. C. Leaf

E. F. Love, K8-34

A. T. Luksic, K8-41

S. C. Marschman (2), P7-14

W. Y. Matsumoto, P7-22

R. J. Migliore, K8-34

K. A. Pauley, K8-34

B. D. Reid (2), K8-34

D. E. Robertson, P8-01

M. A. Showalter, P7-18

C. W. Thomas, P8-01

V. W. Thomas, P8-08

N. J. Wildung (2), P8-10

N. L. Wynhoff, P8-08

E. J. Wyse, P8-08

Publishing Coordination

Technical Report Files (5) 